\title{
14. PLIOCENE-PLEISTOCENE BIOGENIC AND TERRIGENOUS FLUXES AT EQUATORIAL ATLANTIC SITES 662, 663, AND 6641
}

\author{
W. F. Ruddiman ${ }^{2}$ and T. R. Janecek ${ }^{2,3}$
}

\begin{abstract}
High-resolution analyses of sediments at equatorial Atlantic Sites 662, 663, and 664 define the accumulation rates of biogenically produced $\mathrm{CaCO}_{3}$ and opal and of eolian dust from North Africa over the last $3.7 \mathrm{~m} . \mathrm{y}$. The mean flux of opal increased abruptly by $60 \%-70 \%$ near $2.5 \mathrm{Ma}(2.65$ to $2.3 \mathrm{Ma})$, reflecting pulses of increased opal productivity along the equator due mainly to increased upwelling. The mean winter-plume dust influx from Sahelian and Saharan Africa also increased at this time by between $35 \%$ and $75 \%$, following smaller increases earlier in the late Pliocene.

The increased opal flux implies a stronger zonal component of the southern trade winds in Southern Hemisphere winter. Consistent with this wind configuration, the stronger dust flux suggests a weaker southwesterly monsoonal flow into Africa in Northern Hemisphere summer, thus increasing Sahelian aridity and winter-plume dust fluxes. Dust fluxes to the equator may possibly have also been enhanced by stronger Northern Hemisphere winter trade winds and a more southerly position of the Intertropical Convergence Zone over Africa.

These late Pliocene biogenic and terrigenous flux changes coincided with the appearance of Northern Hemisphere ice sheets, implying an ultimate causal link. The immediate control on changes in tropical circulation may, however, have been changes in the Atlantic sector of the Southern Ocean.

A steady background trend of increasing winter-plume dust flux occurred from the late Pliocene until the middle Pleistocene. This may reflect a progressive, tectonically induced aridification of northern and eastern Africa because of the gradual uplift of the Tibetan Plateau.
\end{abstract}

\section{INTRODUCTION}

Leg 108 cored three sites along the equator in the Atlantic Ocean (Fig. 1 and Table 1). Two sites in the eastern equatorial Atlantic (662 and 663) are combined to provide a nearly complete record of most of the last 3.7 m.y. of equatorial sedimentation. Site 664 in the central equatorial Atlantic provides a comparable record of the latest Neogene.

Because divergence occurs today along the equator, one objective was to study the Pliocene-Pleistocene history of equatorial divergence based on $\mathrm{CaCO}_{3}$ and opal, two biogenic components produced by plankton in surface waters and partially preserved in sediments. The second objective was to monitor terrigenous sediment influxes from Africa as an index of continental aridity and atmospheric circulation.

\section{STRATIGRAPHY AND CHRONOLOGY}

All three Leg 108 equatorial sites are bedeviled by late Pliocene to middle Pleistocene slumps (Fig. 2). In addition, the remanent magnetism of the sediments was too weak for the shipboard magnetometers to provide useful stratigraphies, except for the upper Pleistocene section at Site 664. Despite these problems, we also obtained long undisturbed late Pliocene and Pleistocene sequences at Sites 662, 663, and 664.

\section{Age-Depth Trends}

Age-depth curves from Holes 662A, 663A, 664B, and 664D are shown in Figure 2, along with slumps and turbidites. Many slumps have totally disturbed the sediments, creating folded, flowed, and contorted layers that are of no use to this study. Other slumps have deformed the sediments to a lesser degree,

\footnotetext{
${ }^{1}$ Ruddiman, W., Sarnthein, M., et al., 1989. Proc. ODP, Sci. Results, 108. College Station, TX (Ocean Drilling Program).

2 Lamont-Doherty Geological Observatory, Palisades, NY 10964.

3 Present address: Ocean Drilling Program, 1000 Discovery Drive, College Station, TX 77840 .
}

causing slight tilting of layers or sharpening of contrasts across originally bioturbated contacts.

The age-depth trends in Figure 2 for Holes 663A, 664B, and 664D are based on datums reported during Leg 108 (Ruddiman, Sarnthein, et al., 1988). For Hole 662A, we also list in Table 2 one revised discoaster datum determined by Chepstow-Lusty et al. (this vol.) and a revised foraminiferal datum from Karlin et al. (this vol.). Nannofossil datums are most numerous in the Pliocene and lowermost Pleistocene sections between and below the slumps. In all four holes, deposition rates in sections with pelagic deposition range between 30 and $50 \mathrm{~m} / \mathrm{m} . \mathrm{y}$.

Shipboard chronostratigraphic control was poor in the short sections lying between the early and middle Pleistocene slumps (Fig. 2). The interval encompassing Cores 108-664D$11 \mathrm{H}$ and $-12 \mathrm{H}$ has two datums; the interval encompassing Cores $108-662 \mathrm{~A}-8 \mathrm{H}$ and $-9 \mathrm{H}$ has none.

Stratigraphic control was generally somewhat better above the slumps. The Pseudoemiliania lacunosa extinction at 0.47 Ma (Thierstein et al., 1977) is observed at all sites, as is the oxidized layer at the sediment-water interface marking the Holocene. At Site 664, the Brunhes/Matuyama boundary and Jaramillo event were also determined, but no magnetic reversals were detected at Sites 662 and 663.

\section{Additional Isotopic Stratigraphy}

To supplement age control in the upper Pleistocene section of Hole $663 \mathrm{~A}$, we analyzed the planktonic foraminifer $\mathrm{Globi}$ gerinoides ruber for $\delta^{18} \mathrm{O}$ values across two intervals, one (4.5-8 mbsf) located about half-way between the top of Core $108-662 \mathrm{~A}-1 \mathrm{H}$ and the $P$. lacunosa datum, and the other (22-32 mbsf) just above the uppermost slump (Fig. 2). All G. ruber analyses are based on the $>330-\mathrm{m}$ size fraction and were made with a Carousel- 48 automatic carbonate preparation system attached to a Finnegan MAT-251 mass spectrometer. Calibration to the PDB standard is via the NBS-16, NBS-17, and NBS-20 standards. 


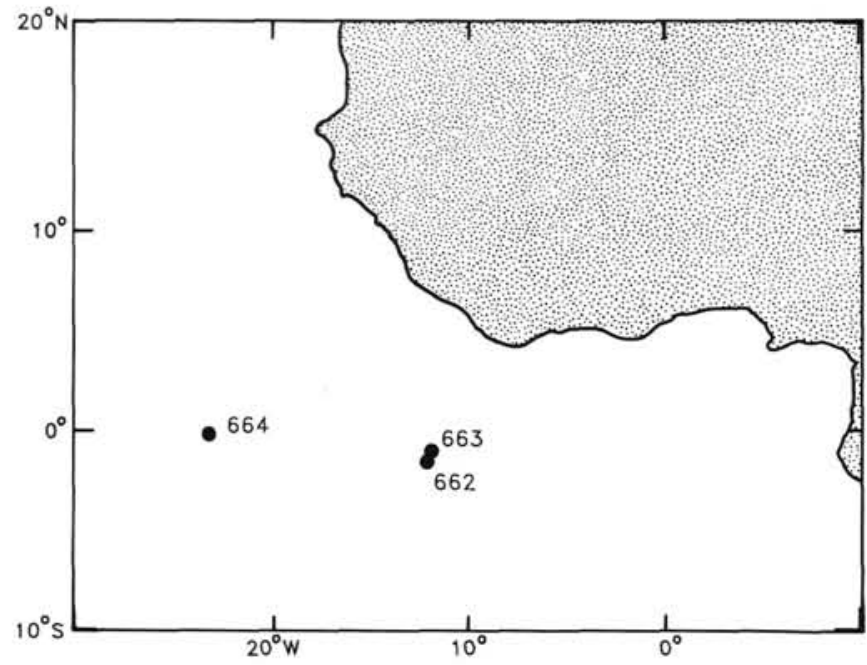

Figure 1. Locations of Leg 108 Sites 662, 663, and 664.

The $\delta^{18} \mathrm{O}$ sequences are shown in Figure 3 and listed in Table 3. Both are correlative with the SPECMAP isotopic stratigraphy of Imbrie et al. (1984). The upper sequence begins in the lower part of isotopic stage 6, extends through stage 7 , and ends at the stage $7 / 8$ boundary. We selected the prominent heavy $\delta^{18} \mathrm{O}$ event (7.4) in the lower-middle portion of interglacial stage 7 for time control.

The lower sequence begins in the upper part of isotopic stage 16, extends through stages $17-22$, and ends in stage 23 . All isotopic stages appear to correlate with the SPECMAP isotopic "stack" (Imbrie et al., 1984). The stage 18.4 event is stronger in our record than in the SPECMAP stack, but it is similar to the amplitude observed in several other highresolution $\delta^{18} \mathrm{O}$ records (Prell, 1982; Shackleton and Hall, 1983; Shackleton et al., 1984). From this sequence, we selected glacial event 16.2, interglacial event 19.1, and glacial event 22.4 for time datums. Depths and ages of these three isotopic events are listed in Table 2.

\section{COMPOSITE DEPTH MODELS}

We constructed two preliminary composite depth sections, one for eastern equatorial Atlantic Holes 662 A and 663A, and the other for central equatorial Atlantic Holes 664B and 664D (Fig. 4). These sections rely on cores with undisturbed pelagic sedimentation and avoid slumps. There are intervals of time not represented in these composite sections: $0.8-1.4 \mathrm{Ma}$ at combined Sites 662 and 663 , and roughly $1.2-2.0 \mathrm{Ma}$ and 2.4-2.5 Ma at Site 664 .

There has been as yet no attempt to obtain continuous signals across core breaks by splicing into offset holes. Small discontinuities thus occur at each core break, probably averaging $25 \mathrm{~cm}$ or less (roughly $5,000-8,000 \mathrm{yr}$ ).

\section{ANALYTICAL METHODS}

The percentage of $\mathrm{CaCO}_{3}$ was determined on $0.5-\mathrm{g}$ sediment samples using the vacuum-gasometric method of Jones and Kaiteris (1983), with a precision of about $1 \%$. The $\mathrm{CaCO}_{3}$ values ranged from $55 \%$ to $90 \%$. Duplicate analyses were run on all outlier values to verify the initial results.

Opal content was determined on 0.5 -g sediment samples using the silica extraction technique of Mortlock and Froelich (in press), with a precision of $6 \%$ relative to the absolute value measured. The amount of silica measured is multiplied by 2.4 to convert to opal (incorporating water of hydration). Measured opal contents ranged from $0 \%$ to
Table 1. Site locations and depths.

\begin{tabular}{lllc}
\hline Hole & Latitude & Longitude & $\begin{array}{c}\text { Depth } \\
\text { (mbsf) }\end{array}$ \\
\hline $662 \mathrm{~A}$ & $1^{\circ} 23.4^{\prime} \mathrm{S}$ & $11^{\circ} 44.4^{\prime} \mathrm{W}$ & 3824 \\
$663 \mathrm{~A}$ & $1^{\circ} 11.9^{\prime} \mathrm{S}$ & $1^{\circ} 52.7^{\prime} \mathrm{W}$ & 3708 \\
$664 \mathrm{~B}$ & $0^{\circ} 06.4^{\prime} \mathrm{N}$ & $23^{\circ} 13.7^{\prime} \mathrm{W}$ & 3817 \\
$664 \mathrm{D}$ & $0^{\circ} 06.4^{\prime} \mathrm{N}$ & $23^{\circ} 16.5^{\prime} \mathrm{W}$ & 3812 \\
\hline
\end{tabular}

$12 \%$, indicating precision errors of no more than $0.7 \%$. Duplicate analyses were run on all outlier values to verify the initial results.

The percentage of nonbiogenic sediment was calculated as a residual by subtracting the percentage of $\mathrm{CaCO}_{3}$ and the percentage of opal from the bulk sediment. Most nonbiogenic sediment is eolian dust from Africa. Some may be authigenic clays and minerals formed on the mid-Atlantic Ridge, as well as other ocean-derived sediments such as manganese micronodules. But shipboard smear-slide and X-ray diffraction (XRD) analyses (Ruddiman, Sarnthein, et al., 1988) indicate that such mineral types are rare. Thus, we call the nonbiogenic fraction the "terrigenous" sediment. It ranges from $4 \%$ to $43 \%$ of the total.

All percentage values of these three major sediment components are listed in Tables 4 (Hole 662A), 5 (Hole 663A), 6 (Hole 664B), and 7 (Hole 664D) at the end of this chapter.

\section{RESULTS}

We first present the downcore trends of the carbonate, opal, and terrigenous fractions. These form the basis for calculating changes in absolute fluxes across selected time intervals.

\section{Percentage Trends}

The percentage values of carbonate, opal, and terrigenous sediment during the late Pliocene and Pleistocene are shown in Figure 5 for the eastern equatorial Atlantic (Holes 662A and 663A) and in Figure 6 for the central equatorial Atlantic (Holes 664B and 664D). All sections were analyzed at $10-\mathrm{cm}$ intervals, equivalent to average time steps ranging between 2000 and $3300 \mathrm{yr}$.

There are several major trends and features in these percentage records. One is a slow drift toward lower $\mathrm{CaCO}_{3}$ and higher opal and terrigenous percentages over the entire $3.5 \mathrm{Ma}$, but most noticeably after about $2.6 \mathrm{Ma}$.

In addition, there are several more abrupt changes, including an important one in the late Pliocene. In the earliest part of each record, the sediment is almost exclusively $\mathrm{CaCO}_{3}$ ooze, except for scattered weak pulses of lower $\mathrm{CaCO}_{3}$ and higher opal and terrigenous values. Near 3.6-3.4 Ma and 3.0-2.9 Ma, a somewhat greater range of variation began to occur, with larger opal and terrigenous maxima and lower $\mathrm{CaCO}_{3}$ minima.

A more fundamental change occurred between 2.6 and 2.4 Ma. Maximum values of opal and terrigenous dust began oscillatory increases as early as $2.6 \mathrm{Ma}$ and reached very large values by $2.4 \mathrm{Ma}$ (Figs. 5 and 6 ). The $\mathrm{CaCO}_{3}$ minima oscillated toward progressively lower values over the same interval. These high-amplitude oscillations have persisted since the late Pliocene.

A second (more subtle) change is the progressive shift to weaker $\mathrm{CaCO}_{3}$ maxima and terrigenous minima during the late Pleistocene, particularly after $0.47 \mathrm{Ma}$. The $\mathrm{CaCO}_{3}$ minima and the terrigenous maxima do not, however, differ markedly from values in earlier sections.

The interpretation of percent data is ambiguous because changes in only one component in a closed system may create artifactual responses in the other components. The history of the change of each component requires the calculation of mass fluxes per unit time. 
DEPTH (in mbsf)
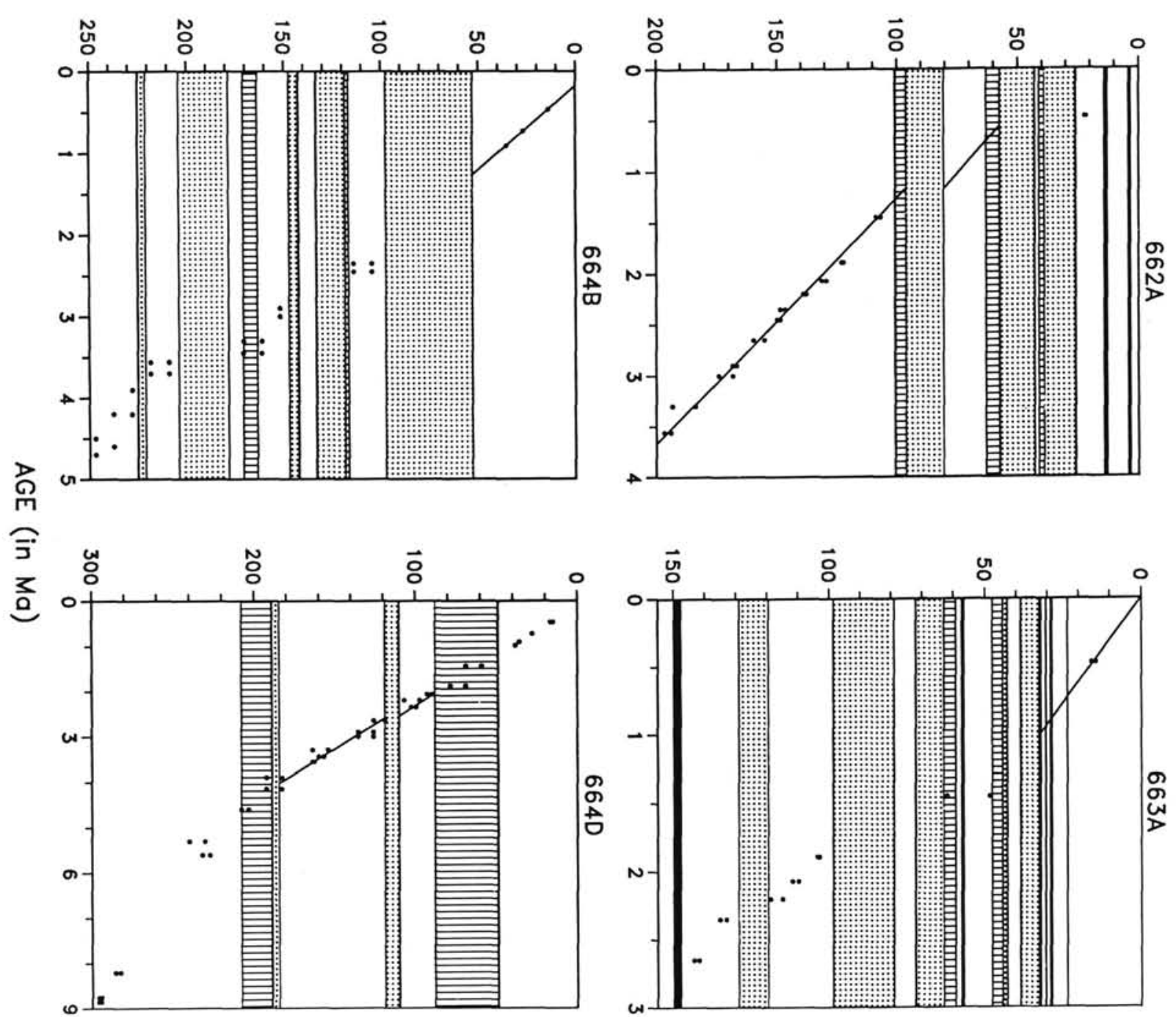

Figure 2. Age/depth plots for Holes 662A, 663A, 664B, and 664D. Datums are from Ruddiman, Sarnthein, et al. (1988), with revised datums at Hole 662A from Chepstow-Lusty et al. (this vol.). Turbidites are black; confirmed slumps are heavy dots; less disturbed sediments (slight tilting indicating slumping) shown by vertical ruling. Solid diagonal lines mark sections analyzed in this study.

\section{Calculation of Long-Term Fluxes}

Mass flux calculations require time control, and the chronologic datums chosen in turn define the maximum resolution at which flux changes can be meaningfully resolved. We list in Table 2 all datums used for our flux calculations. We retain all paleomagnetic and isotopic levels from the middle and late Pleistocene because their depths are closely fixed and their ages accurately known (Mankinen and Dalrymple, 1979; Imbrie et al., 1984).

For the two upper Pliocene sections, we omit several datums from shipboard and shore-based work in order to minimize errors in flux calculations. These errors become larger as the intervals over which fluxes are calculated become smaller, because the uncertainties involved (in fixing the depths of the datums and in knowledge of their true ages) become larger fractions of the duration of the interval through which the fluxes are being calculated. By integrating over intervals considerably longer than these uncertainties, we minimize errors in the flux calculations.

Flux determinations require calculations of the form:

$$
\begin{gathered}
\text { (component mass flux })=(\text { fraction of component }) \\
\times(\text { sedimentation rate }) \times(\text { dry-bulk density }) \\
{\left[\mathrm{g} / \mathrm{cm}^{2} / \mathrm{k} . \mathrm{y} .\right]=[\mathrm{g} / \mathrm{g}] \times[\mathrm{cm} / \mathrm{k} . \mathrm{y} .] \times\left[\mathrm{g} / \mathrm{cm}^{3}\right]}
\end{gathered}
$$

Sample-by-sample calculations of flux values are made, and all flux values lying between constraining time datums are averaged to calculate mean fluxes across that interval. 
Table 2. Datum levels constraining flux calculations shown in Figures 7 and 8.

\begin{tabular}{lrrl}
\hline Hole & $\begin{array}{r}\text { Depth } \\
(\mathrm{mbsf})\end{array}$ & $\begin{array}{c}\text { Age } \\
(\mathrm{m} . \mathrm{y} .)\end{array}$ & \multicolumn{1}{c}{ Datum } \\
\hline $662 \mathrm{~A}$ & 107.65 & 1.450 & LO Calcidiscus macintyrei \\
$662 \mathrm{~A}$ & 149.25 & 2.450 & LO Discoaster surculus \\
$662 \mathrm{~A}$ & 167.70 & 2.900 & LO Dentogloboquadrina altispira \\
$662 \mathrm{~A}$ & 195.30 & 3.560 & LO Reticulofenestra pseudoumbilica \\
$663 \mathrm{~A}$ & 7.21 & 0.228 & SPECMAP $\delta^{18}$ O Event 7.4 \\
$663 \mathrm{~A}$ & 15.15 & 0.470 & LO Pseudoemiliania lacunosa \\
$663 \mathrm{~A}$ & 22.49 & 0.631 & SPECMAP $\delta^{18}$ O Event 16.23 \\
$663 \mathrm{~A}$ & 26.99 & 0.734 & SPECMAP $\delta^{18}$ O Event 19.1 \\
$663 \mathrm{~A}$ & 31.01 & 0.814 & SPECMAP $\delta^{18}$ O Event 22.4 \\
$664 \mathrm{~B}$ & 14.00 & 0.470 & LO Pseudoemiliania lacunosa \\
$664 \mathrm{~B}$ & 27.00 & 0.734 & Brunhes/Matuyama Boundary \\
$664 \mathrm{~B}$ & 35.50 & 0.900 & Top Jaramillo Subchron \\
$664 \mathrm{D}$ & 89.60 & 2.070 & FO Discoaster triradiatus acme \\
$644 \mathrm{D}$ & 102.40 & 2.350 & LO Discoaster pentaradiatus \\
$644 \mathrm{D}$ & 135.30 & 3.000 & LO Sphaerodinellopsis seminulina \\
$664 \mathrm{D}$ & 163.80 & 3.560 & LO Reticulofenestra pseudoumbilica \\
$664 \mathrm{D}$ & 182.80 & 3.900 & LO Globigerina nepenthes \\
\hline
\end{tabular}

Note: Midpoints of range of uncertainty in depth placement of biostratigraphic datums were used. $\mathrm{LO}=$ last occurrence and $\mathrm{FO}=$ first occurrence.

Dry-bulk density (Dbd) is calculated as:

$$
\operatorname{Dbd}=\rho_{\text {sed }}(1-\phi),
$$

where $\rho_{\text {sed }}$ is sediment grain density (taken as $2.65 \mathrm{~g} / \mathrm{cm}^{3}$ ) and $\phi$ is the sediment porosity.

The sediment porosity is derived from:

$$
\phi=\frac{\left(\mathrm{A} \times \mathrm{W}_{\mathrm{d}}\right) / \rho_{\mathrm{sw}}}{\frac{\left(\mathrm{A} \times \mathrm{W}_{\mathrm{d}}\right)}{\rho_{\mathrm{sw}}}+\frac{\left(1-\mathrm{W}_{\mathrm{d}}(1-\mathrm{A})\right)}{\rho_{\mathrm{sed}}}},
$$

where $\mathrm{A}(1.03646)$ is a constant that converts pure water mass to seawater mass, $\mathrm{W}_{\mathrm{d}}$ is dry water content (in $\mathrm{g} / \mathrm{g}$ ), and $\rho_{\mathrm{sw}}$ is the density of pore fluids, assumed to be seawater at 35 per mil salinity $\left(1.02336 \mathrm{~g} / \mathrm{cm}^{3}\right)$.

Water content values for most samples were determined directly from samples taken on shipboard. Samples were stored in plastic vials refrigerated at $5^{\circ} \mathrm{C}$, and then weighed, dried, and weighed again in the lab. Values for most samples are listed in Tables 4 through 7 .

At Hole 662A, water-content values were lacking for a few samples in Core 108-662A-13H, and for a majority of samples in Cores $108-662 \mathrm{~A}-21 \mathrm{H}$ and $-22 \mathrm{H}$. In these three cores, we averaged the available water-content measurements on a section-by-section basis in order to calculate average dry bulk densities per section and thus longer-term flux changes.

No laboratory water contents or bulk density values were made on samples from Cores 108-664D-15H through $-19 \mathrm{H}$. For the purposes of flux calculations, we assigned dry-bulk densities to each of these samples based on shipboard GRAPE measurements. We first calculated average bulk densities for each core using the 5 to 6 GRAPE values per core reported in Ruddiman, Sarnthein, et al. (1988). We next multiplied these averages by 1.06 to convert the GRAPE bulk densities to laboratory values. This conversion was based on a comparison of laboratory and GRAPE bulk densities over the interval $130-200 \mathrm{~m}$ of Hole $662 \mathrm{~A}$, through which mean bulk densities were nearly constant with little high-frequency variability. We then used these adjusted averages as dry-bulk densities for each sample in each core for the flux calculations.

Long-term flux trends for the eastern and central equatorial Atlantic are shown in Figures 7 and 8. The fluxes are plotted as histograms of average values between constraining datum levels.

\section{Gradual Flux Trends over the Last 3.5 m.y.}

The long-term flux patterns (Figs. 7 and 8) confirm some, but not all, of the trends predicted by the percentage curves (Figs. 5 and 6). The flux of $\mathrm{CaCO}_{3}$ was nearly constant through the Pliocene but decreased in the middle to late Pleistocene.

The mass fluxes of opal and terrigenous sediment increased from the late Pliocene into the early and middle Pleistocene, in basic agreement with the percentage data. Both fluxes, however, then decreased during the late Pleistocene. These decreases (not evident in the percent trends) are caused mainly by lower sedimentation rates (Figs. 7 and 8 ).

\section{Abrupt Late Pliocene Flux Changes}

Major opal and terrigenous flux changes occurred $\sim 2.5 \mathrm{Ma}$ (Figs. 7 and 8). Although it is difficult to pinpoint the age of these changes exactly due to uncertainties in depth placement and age of the chronostratigraphic datum levels, it is likely that the flux change is linked to the prominent late Pliocene changes in percentage values for opal and terrigenous dust previously noted. These percent changes occur well below datum levels dated to $2.35 \mathrm{Ma}$ and just below a datum dated to $2.45 \mathrm{Ma}$, but above a datum dated to $2.65 \mathrm{Ma}$ (Figs. 5 and 6). Linear interpolation suggests that this percentage change (and probably the flux change) began between 2.6 and $2.4 \mathrm{Ma}$, with a midpoint age of about $2.5 \mathrm{Ma}$. At Hole 664D, the major flux changes appear to occur within a short interval lost to slumping, but constrained between 2.35 and 2.65 Ma (Fig. 8). For the rest of this paper, we refer to these flux changes as occurring "near 2.5 Ma."

Given the chronostratigraphic uncertainties, the flux of the dominant $\mathrm{CaCO}_{3}$ component stayed roughly constant at both sites near $2.5 \mathrm{Ma}$ (Figs. 7 and 8 ). As a result, sedimentation rates and total sediment fluxes remained nearly constant at both sites. In contrast, the mean accumulation rates of the smaller opal and terrigenous dust fractions increased markedly at this time. The average accumulation of opal increased by $\sim 60 \%-70 \%$ at both sites, with the exact value depending on the intervals chosen as baselines for the calculations. The average accumulation of terrigenous dust increased by about $35 \%$ at Site 662 and $75 \%$ at Site 664 .

Much of the actual late Pliocene flux increases probably occurred within the short pulses evident in the percent data (Figs. 5 and 6). If sedimentation rates over these short intervals stayed roughly linear as in well-dated late Pleistocene piston cores at these sites (Mix and Ruddiman, 1986; McIntyre et al., 1989), then the opal and terrigenous flux increases during these pulses may have been several times larger than the mean flux changes. Curry and Lohman (1986) suggested that terrigenous influxes to the Sierra Leone Rise at $3^{\circ}-5^{\circ} \mathrm{N}$ increased by a factor of 2 or more during late Pleistocene glacial intervals.

For both the terrigenous and opal fractions, the flux change near 2.5 Ma may have had smaller precursors. The mean terrigenous flux appears to have increased slightly across datum boundaries at $2.9 \mathrm{Ma}$ (Fig. 7) and 3.0 Ma (Fig. 8). At Site 664 , the increase in mean opal percentages after about 3.0 $\mathrm{Ma}$ appears to indicate some increase in flux (Fig. 8). At this point, however, the time resolution is not sufficient to assess whether these are significant changes in accumulation rates.

\section{Flux Changes during the Late Pleistocene}

Additional flux changes are recorded during the late Pleistocene: large decreases in opal and terrigenous sediment occur, along with even larger decreases in $\mathrm{CaCO}_{3}$ (Figs. 7 and 


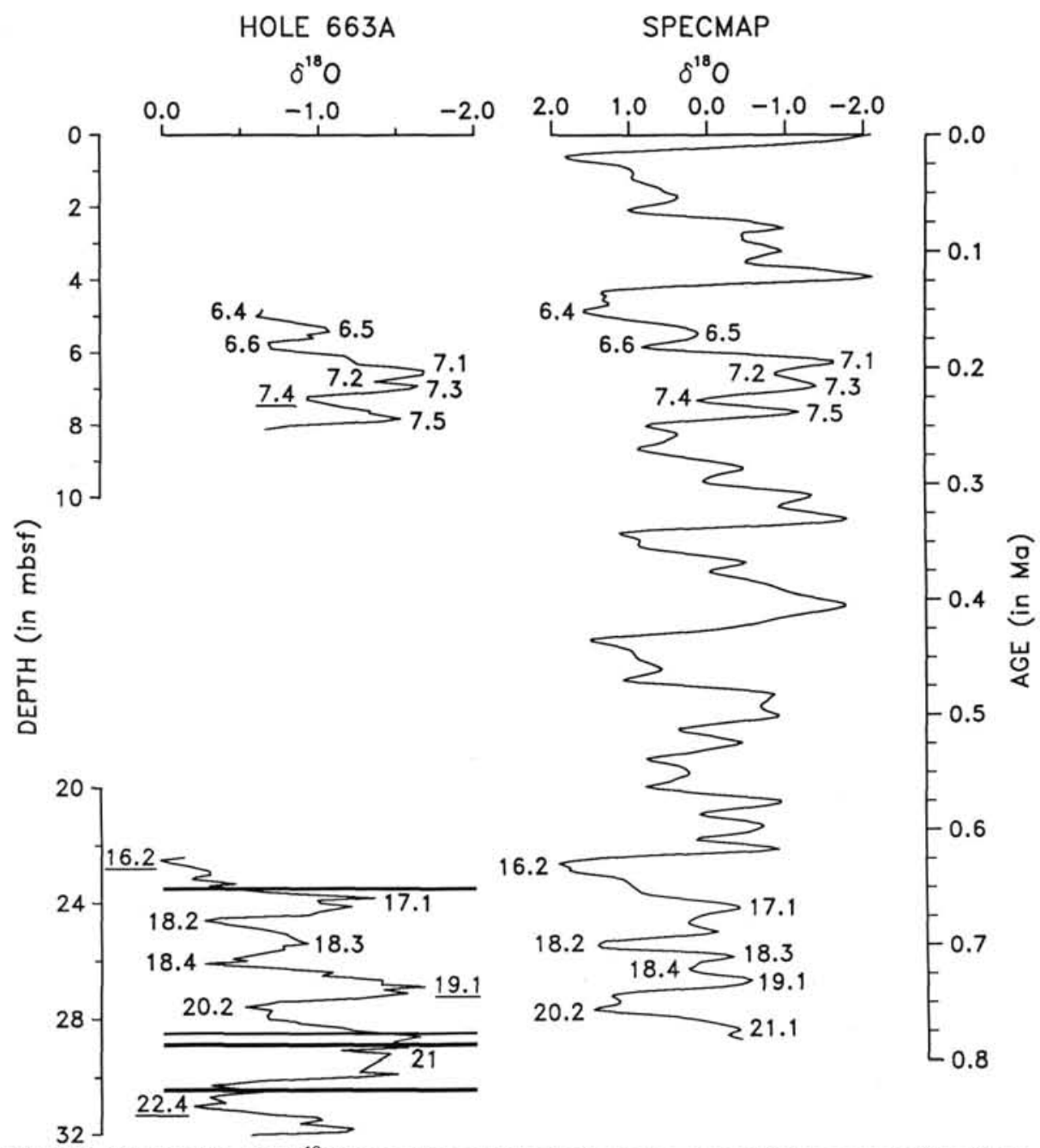

Figure 3. Oxygen isotopic $\left(\delta^{18} \mathrm{O}\right)$ record for middle Pleistocene and late Pleistocene sections from Hole 663A, using planktonic foraminifer Globigerinoides ruber. Major isotopic stages in Hole $663 \mathrm{~A}$ are determined by correlation to the composite $\delta^{18} \mathrm{O}$ record of SPECMAP from Imbrie et al. (1984), shown on the right with the age scale. Datums with asterisks in the Hole 663A record were used for time control in flux calculations. Thin solid horizontal lines are turbidites.

8). For the opal and terrigenous fractions, the flux changes appear to have begun prior to the $P$. lacunosa datum at $(0.47$ $\mathrm{Ma})$ and to have continued to the present. For $\mathrm{CaCO}_{3}$, the flux change appears to have occurred mainly after $0.47 \mathrm{Ma}$.

Several problems make it difficult to determine whether the late Pleistocene flux changes shown in Figures 7 and 8 are indicative of real climatic change or are artifacts of complications specific to the locations of these sites. One complication results from combining records from different locations. Ideally, flux calculations should be specific to a single site and water depth.

The late Pleistocene flux changes at Site 664 are unequivocally determined, because the last million years or more of record is derived from a single hole (664B). In addition, splicing the late Pleistocene section from Hole 664B to the late Pliocene section from Hole 664D does not alter the fluxes: Holes 664B and 664D are located within $1000 \mathrm{~m}$ (lateral distance) and $5 \mathrm{~m}$ (water depth) of each other, and the mean sedimentation rates above the Jaramillo Subchron differ by only $1 \%$.

This is not the case in the eastern equatorial Atlantic, where the numerous slumps forced us to combine the late
Pleistocene record from Site 663 with the late Pliocene and early Pleistocene record from Site 662. This introduces two potential complexities: (1) Site 663 was located in water $116 \mathrm{~m}$ shallower than Site 662 , possibly causing weaker dissolution of upper Pleistocene sediments; (2) Site 663 had sedimentation rates about one-third lower than Site 662 during the latest Pleistocene, possibly causing lower fluxes.

We can reject the first of these possibilities. Because Site 663 is shallower than Site 662 , it should have weaker depthdependent dissolution and thus higher $\mathrm{CaCO}_{3}$ fluxes during the late Pleistocene, opposite to the observed trend. This makes the observed decrease in $\mathrm{CaCO}_{3}$ flux in the combined record all the more significant, whatever its cause.

We can also for the most part reject the second possibility. The sedimentation rate for the middle Pleistocene $(0.81-0.47$ Ma) section of Site 663 is $46 \mathrm{~m} / \mathrm{m}$.y., slightly larger than the 42 $\mathrm{m} / \mathrm{m}$.y. average for the late Pliocene portion of Site 662 (Figs. 2 and 7). Thus, the shift from Site 662 to 663 (and from Hole 664B to 664D) across the middle Pleistocene slumps introduces no decrease, and in fact a small increase, in sedimentation rates and fluxes in the uppermost Matuyama and lowermost Brunhes Chrons (Figs. 7 and 8). Switching sites 
Table 3. Middle Pleistocene oxygenisotopic data from the planktonic foraminifer Globigerinoides ruber $(>\mathbf{2 5 0}$. $\mu \mathrm{m}$ size fraction) at Hole $663 \mathrm{~A}$, relative to PEE DEE Belemnite.

\begin{tabular}{|c|c|c|}
\hline $\begin{array}{l}\text { Core, section, } \\
\text { interval }(\mathrm{cm})\end{array}$ & $\begin{array}{l}\text { Depth } \\
\text { (mbsf) }\end{array}$ & $\begin{array}{l}\delta^{18} \mathrm{O} \\
(\% 0)\end{array}$ \\
\hline $108-663 \mathrm{~A}-2 \mathrm{H}-1,11$ & 4.81 & -0.64 \\
\hline $108-663 \mathrm{~A}-2 \mathrm{H}-1,21$ & 4.91 & -0.63 \\
\hline $108-663 \mathrm{~A}-2 \mathrm{H}-1,29$ & 4.99 & -0.60 \\
\hline $108-663 \mathrm{~A}-2 \mathrm{H}-1,59$ & 5.29 & -1.04 \\
\hline $108-663 \mathrm{~A}-2 \mathrm{H}-1,71$ & 5.41 & -1.07 \\
\hline $108-663 \mathrm{~A}-2 \mathrm{H}-1,79$ & 5.49 & -0.93 \\
\hline $108-663 \mathrm{~A}-2 \mathrm{H}-1,89$ & 5.59 & -0.97 \\
\hline $108-663 \mathrm{~A}-2 \mathrm{H}-1,101$ & 5.71 & -0.68 \\
\hline $108-663 \mathrm{~A}-2 \mathrm{H}-1,119$ & 5.89 & -0.70 \\
\hline $108-663 \mathrm{~A}-2 \mathrm{H}-1,131$ & 6.01 & -0.98 \\
\hline $108-663 \mathrm{~A}-2 \mathrm{H}-1,139$ & 6.09 & -1.17 \\
\hline $108-663 \mathrm{~A}-2 \mathrm{H}-2,11$ & 6.31 & -1.25 \\
\hline $108-663 \mathrm{~A}-2 \mathrm{H}-2,19$ & 6.39 & -1.49 \\
\hline $108-663 \mathrm{~A}-2 \mathrm{H}-2,29$ & 6.49 & -1.68 \\
\hline $108-663 \mathrm{~A}-2 \mathrm{H}-2,41$ & 6.61 & -1.67 \\
\hline $108-663 \mathrm{~A}-2 \mathrm{H}-2,59$ & 6.79 & -1.36 \\
\hline $108-663 \mathrm{~A}-2 \mathrm{H}-2,71$ & 6.91 & -1.64 \\
\hline $108-663 \mathrm{~A}-2 \mathrm{H}-2,79$ & 6.99 & -1.59 \\
\hline $108-663 \mathrm{~A}-2 \mathrm{H}-2,89$ & 7.09 & -1.36 \\
\hline $108-663 \mathrm{~A}-2 \mathrm{H}-2,101$ & 7.21 & -0.93 \\
\hline $108-663 \mathrm{~A}-2 \mathrm{H}-2,119$ & 7.29 & -0.93 \\
\hline $108-663 \mathrm{~A}-2 \mathrm{H}-2,131$ & 7.51 & -1.17 \\
\hline $108-663 \mathrm{~A}-2 \mathrm{H}-2,139$ & 7.59 & -1.33 \\
\hline $108-663 \mathrm{~A}-2 \mathrm{H}-2,146$ & 7.66 & -1.33 \\
\hline $108-663 \mathrm{~A}-2 \mathrm{H}-3,11$ & 7.81 & -1.53 \\
\hline $108-663 \mathrm{~A}-2 \mathrm{H}-3,19$ & 7.89 & -1.40 \\
\hline $108-663 \mathrm{~A}-2 \mathrm{H}-3,29$ & 7.99 & -0.86 \\
\hline $108-663 \mathrm{~A}-2 \mathrm{H}-3,41$ & 8.11 & -0.66 \\
\hline $108-663 \mathrm{~A}-3 \mathrm{H}-6,71$ & 22.41 & -0.13 \\
\hline $108-663 \mathrm{~A}-3 \mathrm{H}-6,79$ & 22.49 & 0.02 \\
\hline $108-663 \mathrm{~A}-3 \mathrm{H}-6,89$ & 22.59 & -0.04 \\
\hline $108-663 A-3 H-6,101$ & 22.71 & -0.16 \\
\hline $108-663 \mathrm{~A}-3 \mathrm{H}-6,119$ & 22.89 & -0.29 \\
\hline $108-663 \mathrm{~A}-3 \mathrm{H}-6,131$ & 23.01 & -0.30 \\
\hline $108-663 \mathrm{~A}-3 \mathrm{H}-6,139$ & 23.09 & -0.20 \\
\hline $108-663 \mathrm{~A}-3 \mathrm{H}-6,146$ & 23.16 & -0.18 \\
\hline $108-663 \mathrm{~A}-3 \mathrm{H}-7,11$ & 23.31 & -0.46 \\
\hline $108-663 \mathrm{~A}-3 \mathrm{H}-7,19$ & 23.39 & -0.29 \\
\hline $108-663 \mathrm{~A}-3 \mathrm{H}-7,29$ & 23.49 & -0.95 \\
\hline $108-663 \mathrm{~A}-3 \mathrm{H}-7,41$ & 23.61 & -0.65 \\
\hline $108-663 \mathrm{~A}-4 \mathrm{H}-1,11$ & 23.81 & -1.35 \\
\hline $108-663 \mathrm{~A}-4 \mathrm{H}-1,19$ & 23.89 & -0.98 \\
\hline $108-663 \mathrm{~A}-4 \mathrm{H}-1,29$ & 23.99 & -1.00 \\
\hline $108-663 \mathrm{~A}-4 \mathrm{H}-1,41$ & 24.11 & -1.20 \\
\hline $108-663 \mathrm{~A}-4 \mathrm{H}-1,59$ & 24.29 & -0.99 \\
\hline $108-663 \mathrm{~A}-4 \mathrm{H}-1,71$ & 24.41 & -0.92 \\
\hline $108-663 \mathrm{~A}-4 \mathrm{H}-1,79$ & 24.49 & -0.38 \\
\hline $108-663 \mathrm{~A}-4 \mathrm{H}-1,89$ & 24.59 & -0.26 \\
\hline $108-663 \mathrm{~A}-4 \mathrm{H}-1,119$ & 24.89 & -0.62 \\
\hline $108-663 \mathrm{~A}-4 \mathrm{H}-1,131$ & 25.01 & -0.73 \\
\hline $108-663 \mathrm{~A}-4 \mathrm{H}-1,137$ & 25.07 & -0.78 \\
\hline $108-663 \mathrm{~A}-4 \mathrm{H}-2,11$ & 25.31 & -0.87 \\
\hline $108-663 \mathrm{~A}-4 \mathrm{H}-2,19$ & 25.39 & -0.92 \\
\hline $108-663 \mathrm{~A}-4 \mathrm{H}-2,29$ & 25.49 & -0.76 \\
\hline $108-663 \mathrm{~A}-4 \mathrm{H}-2,41$ & 25.61 & -0.77 \\
\hline $108-663 \mathrm{~A}-4 \mathrm{H}-2,59$ & 25.79 & -0.57 \\
\hline $108-663 \mathrm{~A}-4 \mathrm{H}-2,71$ & 25.91 & -0.44 \\
\hline $108-663 \mathrm{~A}-4 \mathrm{H}-2,79$ & 25.99 & -0.53 \\
\hline $108-663 \mathrm{~A}-4 \mathrm{H}-2,89$ & 26.09 & -0.26 \\
\hline $108-663 \mathrm{~A}-4 \mathrm{H}-2,101$ & 26.21 & -0.59 \\
\hline $108-663 \mathrm{~A}-4 \mathrm{H}-2,119$ & 26.39 & -1.08 \\
\hline $108-663 \mathrm{~A}-4 \mathrm{H}-2,131$ & 26.51 & -1.01 \\
\hline $108-663 \mathrm{~A}-4 \mathrm{H}-2,139$ & 26.59 & -1.24 \\
\hline $108-663 \mathrm{~A}-4 \mathrm{H}-2,146$ & 26.66 & -1.40 \\
\hline $108-663 \mathrm{~A}-4 \mathrm{H}-3,11$ & 26.81 & -1.39 \\
\hline $108-663 \mathrm{~A}-4 \mathrm{H}-3,19$ & 26.89 & -1.67 \\
\hline $108-663 \mathrm{~A}-4 \mathrm{H}-3,29$ & 26.99 & -1.41 \\
\hline $108-663 \mathrm{~A}-4 \mathrm{H}-3,41$ & 27.11 & -1.56 \\
\hline $108-663 \mathrm{~A}-4 \mathrm{H}-3,59$ & 27.29 & -1.22 \\
\hline $108-663 \mathrm{~A}-4 \mathrm{H}-3,71$ & 27.41 & -0.73 \\
\hline $108-663 \mathrm{~A}-4 \mathrm{H}-3,79$ & 27.49 & -0.67 \\
\hline $108-663 \mathrm{~A}-4 \mathrm{H}-3,89$ & 27.59 & -0.52 \\
\hline $108-663 \mathrm{~A}-4 \mathrm{H}-3,101$ & 27.71 & -0.69 \\
\hline
\end{tabular}

Table 3 (continued).

\begin{tabular}{lll}
\hline $\begin{array}{c}\text { Core, section, } \\
\text { interval (cm) }\end{array}$ & $\begin{array}{c}\text { Depth } \\
\text { (mbsf) }\end{array}$ & $\begin{array}{c}\delta^{18} \text { O } \\
(\%)\end{array}$ \\
\hline $108-663 \mathrm{~A}-4 \mathrm{H}-3,119$ & 27.89 & -0.66 \\
$108-663 \mathrm{~A}-4 \mathrm{H}-3,131$ & 28.01 & -0.67 \\
$108-663 \mathrm{~A}-4 \mathrm{H}-3,139$ & 28.09 & -0.84 \\
$108-663 \mathrm{~A}-4 \mathrm{H}-3,146$ & 28.16 & -0.87 \\
$108-663 \mathrm{~A}-4 \mathrm{H}-4,11$ & 28.31 & -1.14 \\
$108-663 \mathrm{~A}-4 \mathrm{H}-4,19$ & 28.39 & -1.20 \\
$108-663 \mathrm{~A}-4 \mathrm{H}-4,29$ & 28.49 & -1.42 \\
$108-663 \mathrm{~A}-4 \mathrm{H}-4,41$ & 28.61 & -1.64 \\
$108-663 \mathrm{~A}-4 \mathrm{H}-4,59$ & 28.79 & -1.47 \\
$108-663 \mathrm{~A}-4 \mathrm{H}-4,71$ & 28.91 & -1.54 \\
$108-663 \mathrm{~A}-4 \mathrm{H}-4,79$ & 28.99 & -1.56 \\
$108-663 \mathrm{~A}-4 \mathrm{H}-4,89$ & 29.09 & -1.13 \\
$108-663 \mathrm{~A}-4 \mathrm{H}-4,101$ & 29.21 & -1.45 \\
$108-663 \mathrm{~A}-4 \mathrm{H}-5,11$ & 29.81 & -1.25 \\
$108-663 \mathrm{~A}-4 \mathrm{H}-5,19$ & 29.89 & -1.50 \\
$108-663 \mathrm{~A}-4 \mathrm{H}-5,29$ & 29.99 & -1.23 \\
$108-663 \mathrm{~A}-4 \mathrm{H}-5,41$ & 30.11 & -0.63 \\
$108-663 \mathrm{~A}-4 \mathrm{H}-5,59$ & 30.29 & -0.30 \\
$108-663 \mathrm{~A}-4 \mathrm{H}-5,71$ & 30.41 & -0.14 \\
$108-663 \mathrm{~A}-4 \mathrm{H}-5,79$ & 30.49 & -0.65 \\
$108-663 \mathrm{~A}-4 \mathrm{H}-5,89$ & 30.59 & -0.40 \\
$108-663 \mathrm{~A}-4 \mathrm{H}-5,101$ & 30.71 & -0.29 \\
$108-663 \mathrm{~A}-4 \mathrm{H}-5,119$ & 30.89 & -0.39 \\
$108-663 \mathrm{~A}-4 \mathrm{H}-5,119$ & 30.89 & -0.39 \\
$108-663 \mathrm{~A}-4 \mathrm{H}-5,131$ & 31.01 & -0.19 \\
$108-663 \mathrm{~A}-4 \mathrm{H}-5,139$ & 31.09 & -0.28 \\
$108-663 \mathrm{~A}-4 \mathrm{H}-5,146$ & 31.16 & -0.48 \\
$108-663 \mathrm{~A}-4 \mathrm{H}-6,11$ & 31.31 & -0.70 \\
$108-663 \mathrm{~A}-4 \mathrm{H}-6,19$ & 31.39 & -0.97 \\
$108-663 \mathrm{~A}-4 \mathrm{H}-6,29$ & 31.49 & -1.01 \\
$108-663 \mathrm{~A}-4 \mathrm{H}-6,41$ & 31.61 & -0.87 \\
$108-663 \mathrm{~A}-4 \mathrm{H}-6,59$ & 31.79 & -1.21 \\
$108-663 \mathrm{~A}-4 \mathrm{H}-6,71$ & 31.91 & -1.16 \\
$108-663 \mathrm{~A}-4 \mathrm{H}-6,79$ & 31.99 & -0.56 \\
$108-663 \mathrm{~A}-4 \mathrm{H}-6,89$ & 32.09 & -0.75 \\
$108-663 \mathrm{~A}-4 \mathrm{H}-6,101$ & 32.21 & -1.05 \\
\hline & & \\
\hline
\end{tabular}

does not appear to be the origin of the late Pleistocene flux decreases.

Despite these arguments, we remain uncertain that the calculated late Pleistocene flux changes are typical of the equatorial Atlantic divergence region. This uneasiness derives mainly from the fact that the late Pleistocene decrease in sedimentation rate (along with higher water contents) is the main factor driving the decreased fluxes of all three sediment components (Figs. 7 and 8). Simultaneous decreases in all three sediment fractions could coincidentally occur for climatic reasons, but they also could be a warning that there are complications from local factors. The major decrease in sedimentation rates occurs above the $P$. lacunosa datum $(0.47$ $\mathrm{Ma})$, and the central question is whether these decreases are real or represent local anomalies.

All three equatorial sites lie in local basins receiving more sediment than the surrounding topographic highs. Except for obvious slumps and turbidites, most of this sediment is probably transported by very slow particle-by-particle redistribution of otherwise "pelagic"-looking sediment, a process active in many portions of the Mid-Atlantic Ridge system. If this local redistribution for some reason decreased at both sites during the late Pleistocene, the fluxes to these core sites would also diminish, but not because of a decreased input of $\mathrm{CaCO}_{3}$, opal, and terrigenous dust from surface waters.

Similar decreases in mean sedimentation rates occurred above the $P$. lacunosa datum at Site $663(30 \%)$, Hole 664B $(40 \%)$, and Hole 664D (26\%). The comparably large decreases imply that such a trend may be broadly typical of the equatorial Atlantic. On the other hand, the mean (turbidite-free) sedimentation rate at Site 662 above the $P$. lacunosa datum 


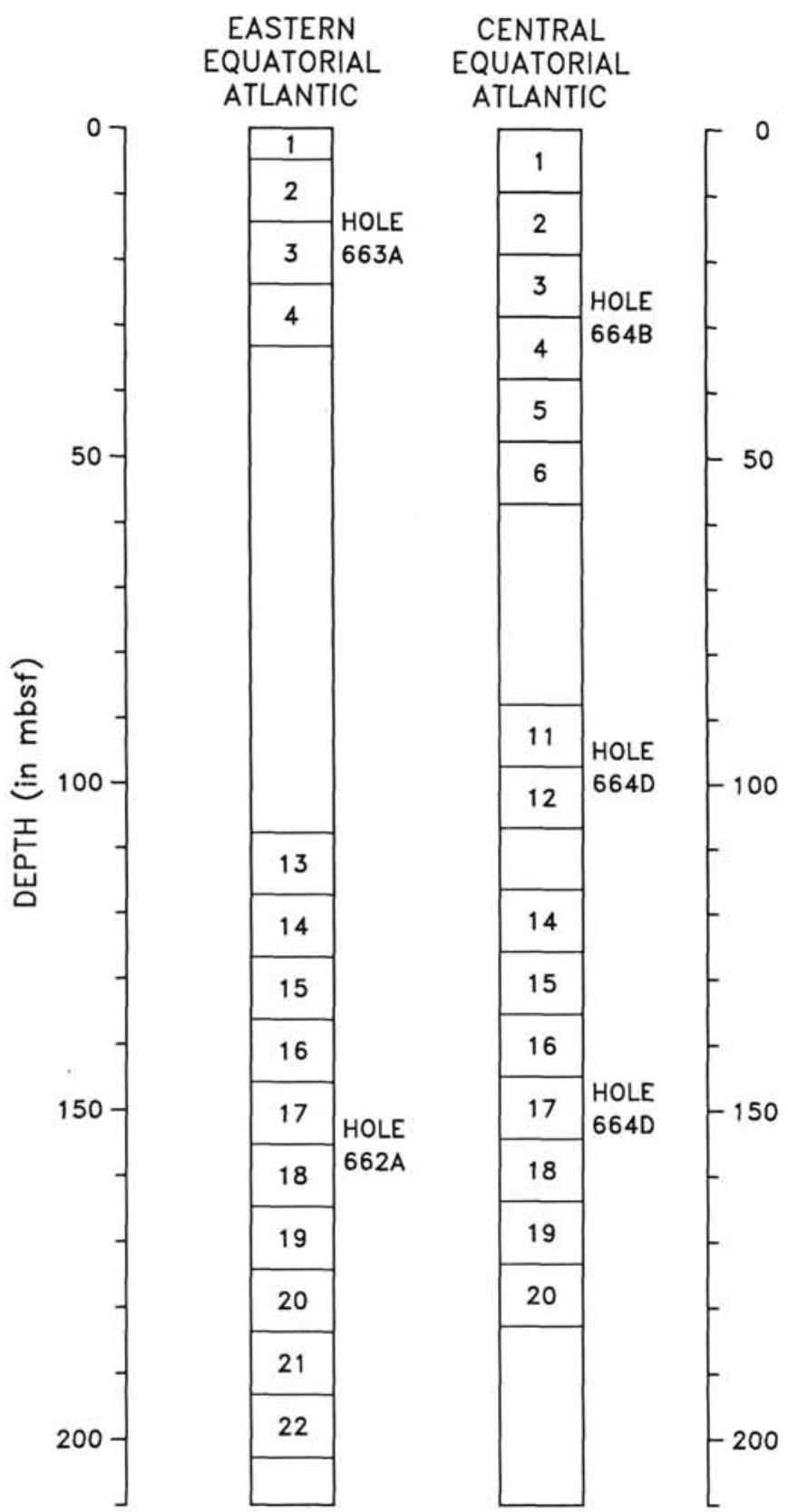

Figure 4. Composite depth sections for eastern equatorial Atlantic Sites 662/663 (combined) and for central equatorial Atlantic Site 664 (Holes 664B/664D). All depths shown in meters are in ODP subbottom depth units (from Ruddiman, Sarnthein, et al., 1988). Core numbers indicated in middle of depth sections. Sections disturbed by slumping are left blank.

$(47 \mathrm{~m} / \mathrm{m} . \mathrm{y}$.$) remained much higher than that at the other sites$ and was also higher than the late Pliocene rate at Site 662 (Fig. 2).

All flux studies ultimately face this same problem. Are the observed flux changes characteristic of the region as a whole, or do they merely indicate the local response of a subset of cores in response to sediment redistribution on the sea floor? Determining the correct possibility would require a study of many sites and of high-resolution seismic records to eliminate local effects, and no other ODP sites exist near the equator in the Atlantic Ocean to address this question. At Leg 108 sites along the African margin, sedimentation rates in the last 1 m.y. either stayed constant or increased (Ruddiman, Sarnthein, et al., 1988), although previously reported DSDP sites farther to the north along the African margin had reduced rates in the late Pleistocene (e.g., Stein and Sarnthein, 1984).

We remain uncertain whether the decreases in sedimentation rate along the equator after $0.47 \mathrm{Ma}$ should be regarded as a regionally typical trend or as local anomalies. This in turn leaves unclear whether the late Pleistocene flux decreases in $\mathrm{CaCO}_{3}$, opal, and terrigenous sediment (Figs. 7 and 8) are regionally representative.

\section{DISCUSSION}

We review here possible explanations for three trends evident in the percentage and flux data (Figs. 5-8): (1) the relatively abrupt late Pliocene increases in opal and terrigenous dust near $2.5 \mathrm{Ma}$; (2) the less abrupt late Pleistocene decreases in all components during the last $0.7-0.4$ m.y.; and (3) the slow background trends spanning all or most of the last $3.7 \mathrm{~m} . \mathrm{y}$.

\section{Late Pliocene Increase in Opal Flux}

Opal preservation in sea-bed sediments is a function mainly of opal productivity in surface waters (Broecker and Peng, 1982; Pokras and Molfino, 1986). Silica derived from oceanic production dominates the opal signals derived here, with opal from sponge spicules and from freshwater diatoms and other continental sources orders of magnitude less abundant (Pokras and Mix, 1985; Stabell, 1986).

Our flux data argue for an increase in mean opal productivity of $\sim 60 \%-70 \%$ in the equatorial Atlantic near $2.5 \mathrm{Ma}$ (Figs. 7 and 8). It is likely that the increases were much larger during episodic high-opal pulses that began at that time and have continued subsequently. In contrast, mean $\mathrm{CaCO}_{3}$ productivity appears to have remained constant near $2.5 \mathrm{Ma}$, to within the error of our estimates (Figs. 7 and 8).

These trends suggest two changes along the equator near $2.5 \mathrm{Ma}$. First, overall productivity $\left(\mathrm{CaCO}_{3}\right.$ plus opal) appears to have increased slightly (Figs. 7 and 8 ). Second, the data imply a shift toward silica productivity, suggesting some combination of higher silica content of upwelled waters and greater advection of silica-rich water at or below the surface. Studies of modern sediment traps (Dymond and Lyle, 1985) and of late Pleistocene $\mathrm{CaCO}_{3}$ and opal fluxes (Lyle et al., 1988) show that $\mathrm{CaCO}_{3}$ and opal components may have weakly related or even opposed productivity trends on a seasonal and long-term basis because of shifts from one kind of productivity to another. Without exception, however, silica deposition today is concentrated in regions of high overall productivity. We thus infer that a major net productivity increase occurred at the equator near $2.5 \mathrm{Ma}$.

Stronger equatorial productivity implies stronger upwelling along the equator, which in turn suggests that the trade winds became stronger and/or more zonal on a periodic basis after $2.5 \mathrm{Ma}$. A similar change has been proposed to explain late Pleistocene changes in sea-surface temperature and marine diatom deposition in the equatorial Atlantic (Gardner and Hays, 1976; Mix et al., 1986; Pokras, 1987; McIntyre et al., 1989).

It is also possible that there was an increase in the silica and nutrient content of the waters being upwelled. This implies shoaling of silica-rich South Atlantic Central Waters and/or upper Antarctic Intermediate Water or increased northward penetration or waters from circumantarctic sources. Increased advection from the south has also been proposed for the late Pleistocene (Gardner and Hays, 1976; 


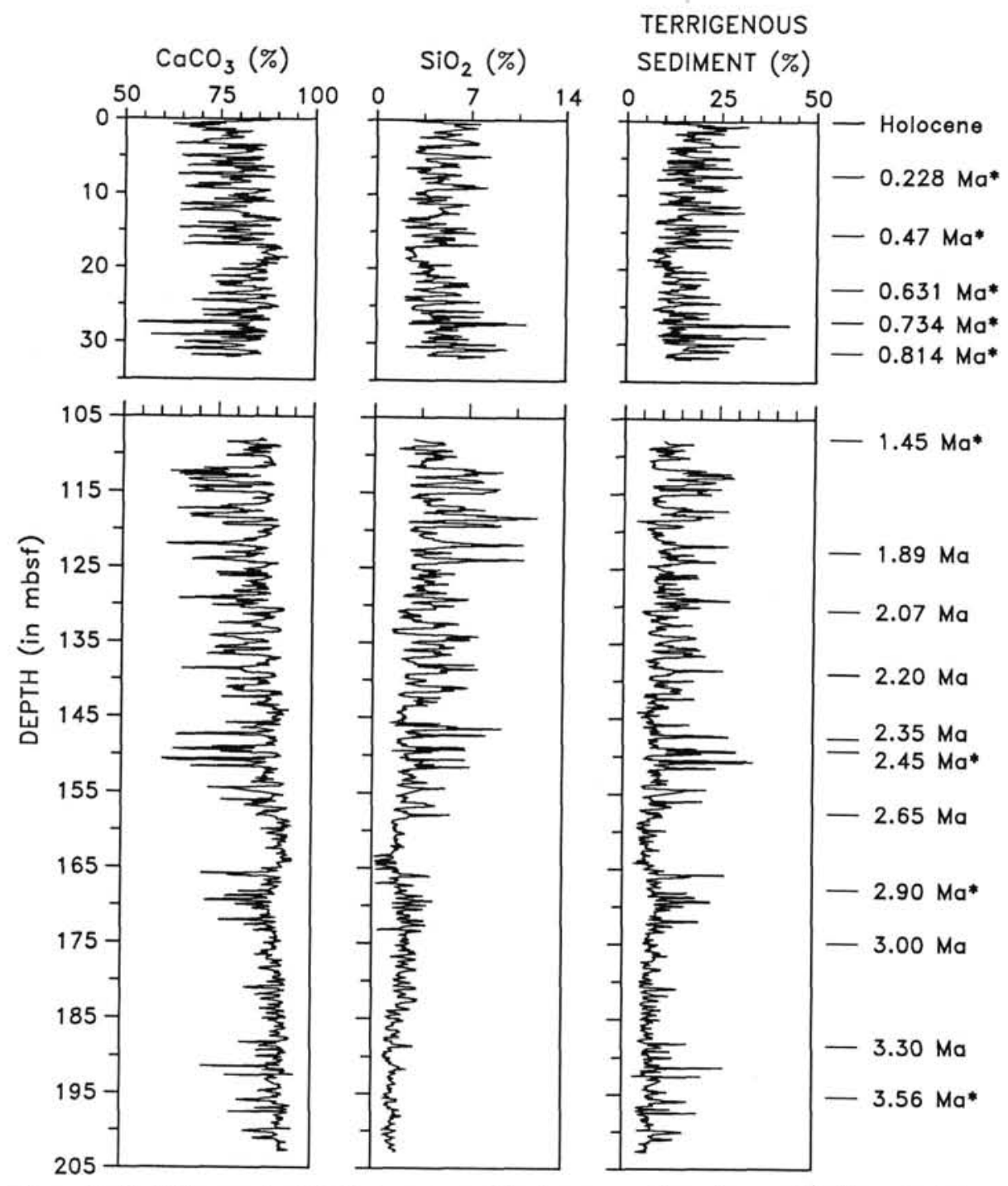

Figure 5. Weight-percent of $\mathrm{CaCO}_{3}$, opal, and terrigenous sediment vs. sub-bottom depth in Pliocene-Pleistocene sections at Holes 662A and 663A. Ages and levels of chronostratigraphic datums used in flux calculations indicated by asterisks on right.

Labracherie, 1980; Mix et al., 1986; Pokras, 1987; McIntyre et al., 1989).

The fact that the late Pliocene change in opal flux along the equator (Figs. 5-8) is relatively abrupt and dates to near 2.5 Ma points to two (probably interrelated) explanations. The change may be associated with the initial development of Northern Hemisphere ice sheets, which attained sufficient size to send ice-rafted sediment to the Atlantic just prior to 2.4 Ma (Backman, 1979; Shackleton et al., 1984; Curry and Miller, this vol.). Conceivably, the appearance of ice sheets might have altered Northern Hemisphere winter circulation and caused upwelling of opal along the equator.

Upwelling could be enhanced along the equator in Northern Hemisphere winter either by increased trade-wind strength or by a more southerly position of the Intertropical Convergence Zone (ITCZ), but opinions on this are mixed. Gardner and Hays (1976) inferred that Northern Hemisphere winter trade winds intensified during glaciations, but Parkin and Padgham (1975) interpreted eolian grain-size data as evidence that they weakened. Nicholson and Flohn (1980) hypothesized a southward displacement of the ITCZ in glacial winters, but Gardner and Hays (1976) inferred no significant change in its position. Mix et al. (1986) inferred that the mean annual position of the ITCZ over the Atlantic may have been farther south during the last deglaciation.

The general circulation model (GCM) experiments to date (without ocean upwelling) also do not point to systematic direct impacts of ice sheets on trade winds over the equatorial Atlantic (summarized in Ruddiman et al., this vol.). Additional GCM experiments with interactive oceans that include upwelling would be needed to test whether the appearance of Northern Hemisphere ice sheets could affect equatorial upwelling during Northern Hemisphere winter. In any case, neither GCM experiments nor data observations at this point provide strong evidence for winter circulation changes due to ice sheets as the cause of increased opal fluxes.

Alternatively, the increased opal flux may be associated with prominent changes in circumantarctic circulation near $2.5 \mathrm{Ma}$, including a shift to colder radiolarian faunas in the southwest Atlantic sector of the Antarctic (Cieselski and Grinstead, 1986; Mead et al., 1988). These changes in antarctic sea-surface temperature (SST) and presumably in antarctic 


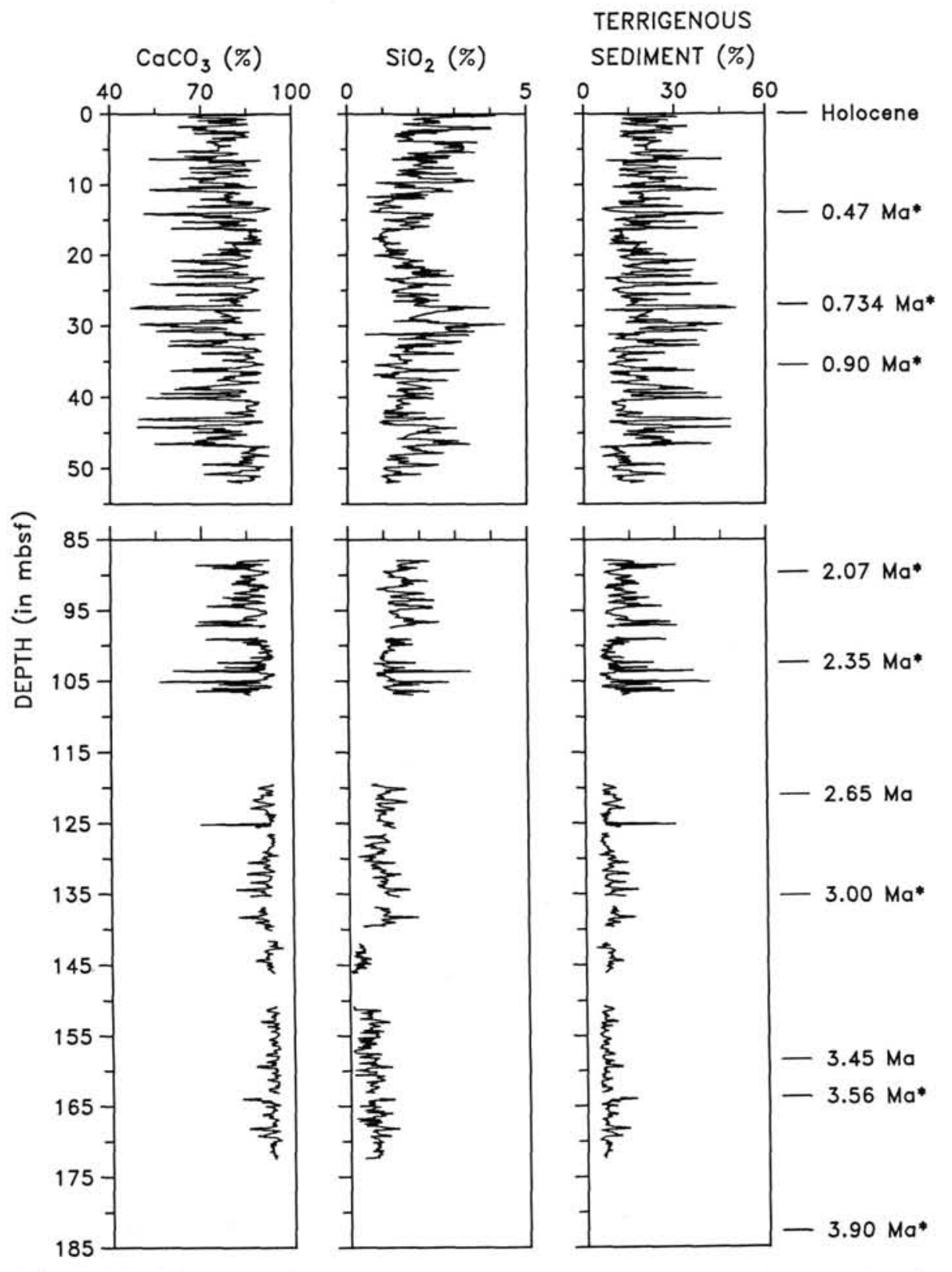

Figure 6. Weight-percent of $\mathrm{CaCO}_{3}$, opal, and terrigenous sediment vs. sub-bottom depth in Pliocene-Pleistocene sections at Holes 664B and 664D. Ages and levels of chronostratigraphic datums used in flux calculations indicated by asterisks on right.

sea ice could effect equatorial Atlantic upwelling and SST by altering southern trade winds and northward advection (Gardner and Hays, 1976; Mix et al., 1986; McIntyre et al., 1989). In addition, changes in circumantarctic circulation could have increased the silica content of Antarctic Intermediate Water and South Atlantic Central Water, which upwell near the equator. Ultimately, the Southern Ocean circulation changes may still have been driven by Northern Hemisphere ice sheets (Cieselski and Grinstead, 1986; Mead et al., 1988).

Southern Hemisphere control of atmospheric circulation over the equatorial Atlantic is also consistent with variations at annual and orbital time scales. Because the thermal equator in the Atlantic lies in the Northern Hemisphere throughout the year, modern ocean temperatures at the equator follow the Southern Hemisphere pattern (August cooler than February). During the last 200,000 yr, equatorial
Atlantic and subantarctic sea-surface responses had similar phasing and high coherences at the 23,000 -yr orbital precession period, suggesting that the equatorial Atlantic response has been at least in part forced from the circumantarctic (McIntyre et al., 1989).

Previously published data on long-term opal trends in the tropical Atlantic are from coastal regions and have been explained by different mechanisms. Using semiquantitative smear-slide analyses, Stein and Sarnthein (1984) noted the appearance of opal after 3.2 Ma at Deep Sea Drilling Project (DSDP) sites from the northwest African margin, and Stein (1985a) put the major increase at Site 397 at $2.55 \mathrm{Ma}$. This was attributed either to (1) increased coastal upwelling due to stronger trade winds in northern summer, or (2) increased fluvial delivery of nutrients as a result of shifts in coastline position due to sea-level changes. 


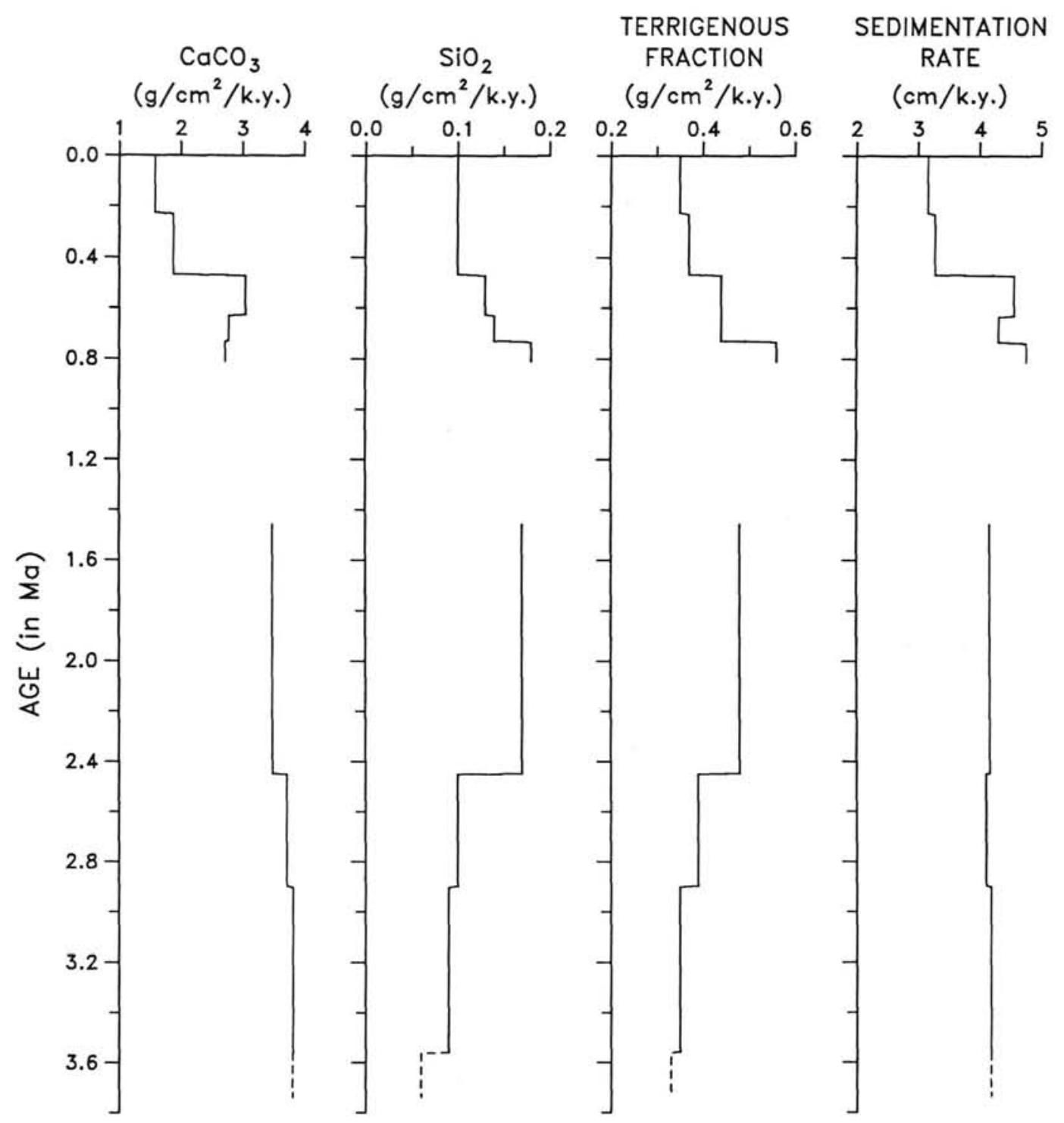

Figure 7. Mass fluxes of $\mathrm{CaCO}_{3}$, opal, and terrigenous sediment in the eastern equatorial Atlantic (Holes $662 \mathrm{~A}$ and $663 \mathrm{~A}$ ). Bar graphs indicate average fluxes between datum levels used as absolute time constraints. Dashed lines show fluxes calculated by downward extrapolation of sedimentation rates in overlying layer. The dotted line shows alternative calculation of late Pleistocene fluxes using sedimentation rates from Hole $662 \mathrm{~A}$ in place of Hole $663 \mathrm{~A}$.

\section{Late Pliocene Increase in Terrigenous Dust Flux}

Winds are the primary transporting agent of terrigenous sediments to Sites 662,663 , and 664 . This conclusion is based on comparing the late Pleistocene total terrigenous fluxes (Figs. 7 and 8) against the late Pleistocene fluxes of the eolian component isolated by Janecek (1985) in nearby equatorial Atlantic piston cores (Fig. 9). The flux numbers for both data sets are in the same range $\left(350-460 \mathrm{mg} / \mathrm{cm}^{2} / \mathrm{k}\right.$.y.).

The dominant dust sources for these sites lie north of the equator, and the dust is carried southwestward in the winter dust plume. Southern Hemisphere sources have previously been proposed as more important along the equator, because the ITCZ was thought to form a barrier to dust from the north (Fütterer, 1978; Sarnthein et al., 1982; Stein, 1985a). Modern dust-induced "haze" patterns, however, show that measurable southern-source haze does not reach the equator, whereas northern dust reaches south of the equator in winter over the eastern and central Atlantic (McDonald, 1938; Prospero, 1981). The northward increase of average eolian mass fluxes during the last $300,000 \mathrm{yr}$ (Fig. 9) also clearly identifies North Africa as the main long-term dust source for Atlantic sediments along the equator.

Prospero (1981) summarized dust injection and transport in the modern winter-haze plume. Dust is injected into the lower and middle troposphere at altitudes of $1.5-7 \mathrm{~km}$ by winter storms in the Sahel. The mean flow toward the west-southwest at these altitudes carries dust far out over the equatorial Atlantic between latitudes $0^{\circ}$ and $20^{\circ} \mathrm{N}$, with measurable haze reaching the coast of South America just north of the equator. The ultimate barrier to southward dust transport is the moist ITCZ, the lower boundary of which lies at a mean position of $3^{\circ}-5^{\circ} \mathrm{N}$ in winter; however, the ITCZ slopes upward gradually to the south, allowing dust transport well south of the equator at altitudes of $1.5-3 \mathrm{~km}$ (see Prospero, 1981, fig. 11). We thus infer that dust delivery to Sites 662,663 , and 664 has mainly 


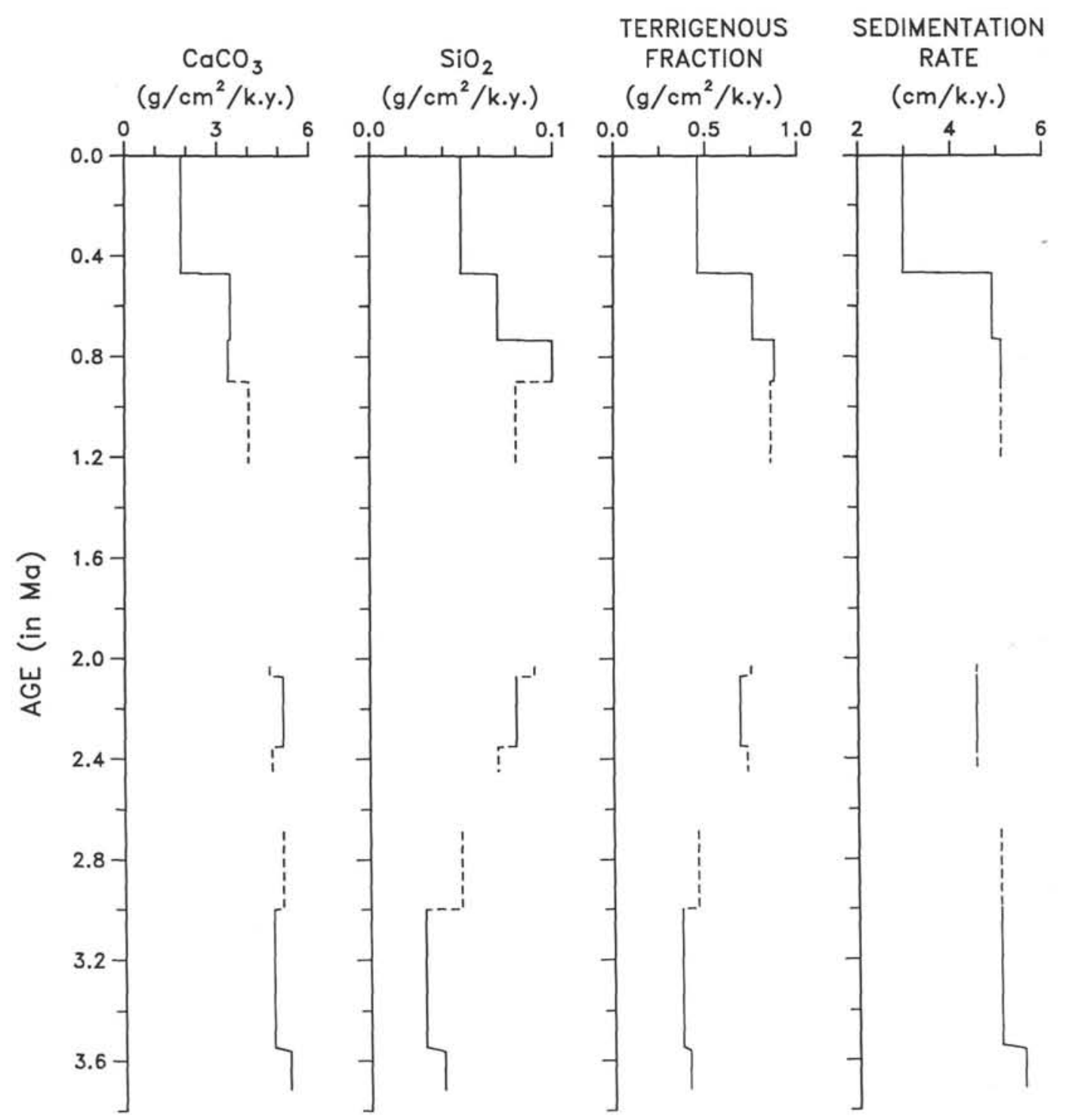

Figure 8. Mass fluxes of $\mathrm{CaCO}_{3}$, opal, and terrigenous sediment in the central equatorial Atlantic (Holes 664B and 664D). Bar graphs indicate average fluxes between datum levels used as absolute time constraints. Dashed lines are estimated fluxes for interval without constraining datum levels at both ends; for these intervals, sedimentation rates are extrapolated from adjacent interval.

occurred in the winter plume at altitudes above $1.5 \mathrm{~km}$ from sources in the Sahel and southern Sahara.

Thus, our records (Figs. 5-8) indicate relatively abrupt increases in the magnitude of oscillatory pulses of dust influx from North Africa to the equatorial Atlantic between 2.6 and 2.4 Ma. Two factors may be involved in these changes: (1) increased dust availability due to changes in moisture balance in the source areas and (2) increased winter-plume dust transport to the equator by altered atmospheric circulation.

Today, rain in the Sahelian and southern Saharan source regions for the winter dust plume falls entirely in Northern Hemisphere summer. This rainfall occurs in connection with a component of the southern winter trade-wind flow that crosses the equator and turns northeastward into Africa in a monsoonal circulation. To increase aridity in the Sahel and thus enhance winter-plume dust fluxes, this meridional flow of moisture into Africa would have to weaken. Such a change is consistent with the increased zonal component of southern trade-wind flow along the equator needed to explain the increased opal flux after $2.5 \mathrm{Ma}$; the two changes suggest a redirection from meridional toward zonal flow. The oscillatory fluxes of both dust and opal suggest, however, that this configuration was not permanent; intervening wetter intervals occurred (apparently at frequencies lying within the orbital band) and probably replenished the soils that formed the basic dust supply during more arid intervals.

Evidence from East Africa also indicates increased aridity during this same late Pliocene interval. Pollen-bearing lake and fluvial sediments, dated by interbedded volcanogenic deposits, indicate a shift toward cyclical high-elevation cooling and low-elevation aridity between 2.52 and $2.38 \mathrm{Ma}$, with aridity cycles continuing through the rest of the Pliocene and into the Pleistocene (Bonnefille, 1983, 1985). East African antelope and micromammal taxa also changed to types indicative of drier climates between 2.52 and $2.38 \mathrm{Ma}$ (Vrba, 1985; Wesselman, 1985). The full geographical extent of Sahelian aridification near 2.5 Ma is not known; dated deposits from the western and central Sahel do not exist. 


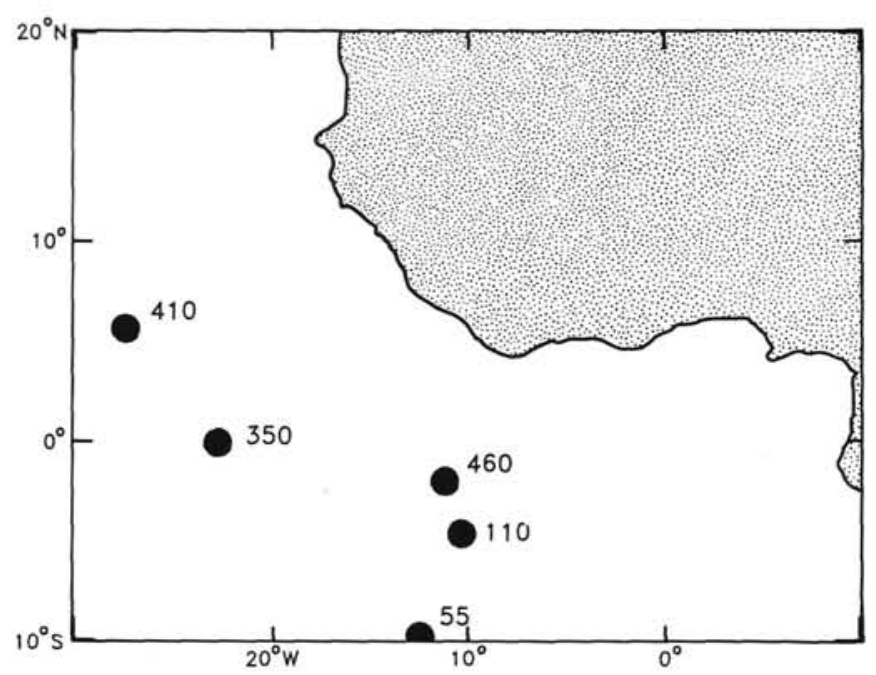

Figure 9. Late Pleistocene ( $0-0.25 \mathrm{Ma}$ ) mass fluxes (in $\mathrm{g} / \mathrm{cm}^{2} / \mathrm{k} . \mathrm{y}$.) of eolian sediment in five equatorial Atlantic piston cores (from Janecek, 1985).

The timing of the increase in dust delivery near $2.5 \mathrm{Ma}$ implies a causal link to the appearance of Northern Hemisphere ice sheets. As noted above, the direct effects of ice sheets on northern trade-wind strength or ITCZ position in the tropics are possible, but unproven.

A more credible case can be made that ice sheets had some influence on moisture balances in Africa. The greater southward extent of dunes in the southern Sahara during the last glacial maximum (Sarnthein, 1978) may indicate that ice sheets imposed a glacial tempo on African aridity; however, the very large increase in dune extent since $6000 \mathrm{yr}$ ago argues that factors other than Northern Hemisphere ice sheets must be involved in these aridity cycles. Pokras and Mix (1985), studying phytolith abundances in marine cores, detected a southward shift of the grass belt along the West African coast $18,000 \mathrm{yr}$ ago, as part of a longer-term glacial/interglacial tempo of aridity near the African coast over the last 150,000 yr.

A GCM experiment (Joussaume and Sadourny, 1987) predicted a doubling (relative to today) of the annual average dust deposited along the equator in the Atlantic during late Pleistocene glacial maxima due mainly to drier source areas and increased convective activity in the Sahel. Thus, changes in glacial boundary conditions during the late Pliocene may have enhanced aridification along at least the coastal regions of West Africa, and this aridification may have increased winterplume dust fluxes from these areas to the equatorial Atlantic.

Other evidence argues, however, that the extent of glacial aridification of Africa is not large, and that an entirely different tempo of aridity dominates much of the interior of North Africa. Pokras and Mix $(1985,1987)$ found that winter-plume transport of diatoms from freshwater lakes in the Sahel during the late Pleistocene occurred mainly at the 23,000 -yr period of orbital precession, rather than at the 100,000 -yr period that dominates ice-volume change. This indicates that aridity cycles in central Africa occurred mainly at the precessional period, consistent with lake-level data and GCM results suggesting the dominance of precessional insolation forcing (Kutzbach, 1981; Kutzbach and Street-Perrott, 1985).

Evidence from sediments in the Niger delta indicates that the highest freshwater discharge during the last 20,000 yr occurred between 13,000 and $4500 \mathrm{yr}$ ago (Pastouret et al., 1978), which is basically the tempo of aridity indicated by precessional insolation forcing rather than that predicted by glacial/interglacial changes. This suggests that even the western parts of the Sahel lying within the Niger basin were influenced mainly by insolation forcing of monsoon strength.

It seems plausible that the northern summer cooling of the central Sahara caused by the combined effects of ice sheets, high-latitude SST, and $\mathrm{CO}_{2}$ (Ruddiman et al., this vol.) would have been sufficient to reduce the strength of the monsoonal inflow into Africa and thus enhance aridification. Most GCM studies, however, find negligible changes in moisture flux to the interior between glacial and modern-day climates (summary in Ruddiman et al., this vol.).

Because cycles of aridity in most of central Africa thus had little resemblance to rhythms of ice-sheet variation during the late Pleistocene, ice sheets apparently had little influence on the moisture balance in these regions within the orbital band. This suggests that direct ice-sheet effects do not explain the more fundamental change in aridity in North African source areas of winter-plume dust near $2.5 \mathrm{Ma}$.

As suggested earlier, circulation changes in the Southern Ocean may have been the intermediary between the "first cause" (initial appearance of Northern Hemisphere ice sheets) and the ultimate result (changes in atmospheric circulation near the equator). To some extent, the geographic pattern of changes in dust fluxes supports this idea. The large dust-flux increase near $2.5 \mathrm{Ma}$ is recorded at all sites under the winter dust plume (Sites 662 and 664 from this paper; Sierra Leone Rise Site 366 reported by Stein, 1985b), but it does not appear in any of the sites under the summer dust plume farther north (Site 659 in Tiedemann et al., this vol.; Site 397 in Stein, 1985a; and Site 141 in Stein, 1986). This suggests that the strongest aridity changes near $2.5 \mathrm{Ma}$ were registered in source regions tapped by the winter but not the summer dust plume. The most likely such regions lie in the southernmost Sahel, which by geographic proximity suggest a connection to the circulation changes in the equatorial Atlantic.

We do not, however, suggest that changes over the equatorial Atlantic caused those over Africa. The synchronous changes in both regions are interpreted as different parts of a common response to changes imposed via the Southern Ocean.

\section{Late Pleistocene Decrease in Carbonate}

For all discussions of late Pleistocene flux changes, we assume that the reduced accumulation rates of carbonate, opal, and terrigenous sediment are due to climate-induced changes in the delivery of these components and not to local factors that affect sediment redistribution.

Average $\mathrm{CaCO}_{3}$ fluxes decreased by more than half at both equatorial sites after $0.47 \mathrm{Ma}$ (Figs. 7 and 8). Stein and Sarnthein (1984) detected similar decreases in $\mathrm{CaCO}_{3}$ accumulation at several DSDP sites in the eastern subtropical Atlantic. The $\mathrm{CaCO}_{3}$ percentages decrease at most Leg 108 sites (Ruddiman, Sarnthein, et al., 1988), but higher sedimentation rates at some sites may offset the lower $\mathrm{CaCO}_{3}$ percentages. In any case, a late Pleistocene decrease in long-term average $\mathrm{CaCO}_{3}$ fluxes appears to be characteristic of deeper tropical Atlantic sites.

The cause of this apparent flux decrease in the late Pleistocene is not clear. Leg 108 shipboard studies did not detect worsening preservation in the late Pleistocene, but observations are too widely spaced to be definitive. Curry and Lohman (1986) found that dissolution reduced $\mathrm{CaCO}_{3}$ accumulation in Sierra Leone Rise cores below $3951 \mathrm{~m}$, but it only affected cores above $3527 \mathrm{~m}$ during extreme intervals. Gardner (1975) found little dissolution in cores as deep as $3750 \mathrm{~m}$. Thus, Sites 662,663 , and 664 lie in the depth range (3708-3824 
m) at which late Pleistocene dissolution has been found to become significant.

Studies of late Pleistocene $\delta^{13} \mathrm{C}$ trends in deep Atlantic cores have shown that the formation of deep water in the North Atlantic was suppressed during glaciations (Boyle and Keigwin, 1985). As a result, waters of southern (antarctic) origin moved farther northward in the western Atlantic, bringing higher nutrient and $\mathrm{CO}_{2}$ concentrations and a greater capacity for dissolving $\mathrm{CaCO}_{3}$ to the equatorial Atlantic region (Oppo and Fairbanks, 1987).

Deep basins in the eastern equatorial Atlantic were affected by southern-source waters passing eastward through deep fracture zones (Curry and Lohman, 1986). These changes predict strong $\mathrm{CaCO}_{3}$ dissolution at the equator in the late Pleistocene, driven largely at the $100,000-\mathrm{yr}$ and $41,000-\mathrm{yr}$ tempo of Northern Hemisphere ice sheets (Boyle and Keigwin, 1985; Mix and Fairbanks, 1985). Longer-term $\delta^{13} \mathrm{C}$ records, however, indicate that the greatest suppression of northern-source waters may have occurred between 0.85 and 0.4 $\mathrm{Ma}$ (Ruddiman et al., in press; Raymo et al., in press), prior to the large decrease in $\mathrm{CaCO}_{3}$ flux observed here.

Curry and Lohman (1986) also found that $\mathrm{CaCO}_{3}$ productivity in surface waters near the Sierra Leone Rise decreased by a factor of 2 or more during late Pleistocene glacial stages. Thus, both productivity suppression and dissolution may have been factors in decreased $\mathrm{CaCO}_{3}$ fluxes in the late Pleistocene (see also Pflaumann, 1986).

\section{Late Pleistocene Decrease in Opal}

Mean opal fluxes at both equatorial sites decreased by around half over the last $0.8 \mathrm{~m} . \mathrm{y}$., reaching the lowest levels in the last $2.5 \mathrm{~m} . \mathrm{y}$. (Figs. 7 and 8). These flux decreases preceded those of the carbonate fraction by several hundred thousand years. If these flux decreases are not artifacts of local sediment redistribution, they imply a return part of the way toward the climatic regime that prevailed prior to $2.5 \mathrm{Ma}$, with weaker equatorial upwelling. This in turn implies a weaker zonal component of the southern trade-wind flow along the equator during Northern Hemisphere summer.

Despite the mean decrease in opal flux, however, strong percentage variations continued, suggesting that the change in opal flux was not registered by a complete cessation of the periodic opal pulses that began at $2.5 \mathrm{Ma}$ (Figs. 5 and 6). Because of the dominant influence of the $\mathrm{CaCO}_{3}$ fluxes on the oscillating percentage trends, it is impossible to infer anything about the tempo of decreasing opal fluxes at higher frequencies.

Two factors may have altered opal fluxes between 0.8 and $0.4 \mathrm{Ma}$. Forcing by Northern Hemisphere ice sheets is a possibility, because this is the interval during which they changed from smaller variations at $41,000 \mathrm{yr}$ to larger 100,000-yr variations (Pisias and Moore, 1981; Prell, 1982; Ruddiman et al., 1986). Forcing from the Southern Hemisphere is also possible; significant changes in radiolarian and foraminifer faunas in subantarctic sediments have been reported for this interval, but these changes have been variously interpreted as a shift toward periodically warmer intervals (Keany and Kennett, 1972) or as a long-term cooling (Hays, 1967). In view of this disagreement, it is premature at this time to try to link the apparent late Pleistocene change in equatorial opal fluxes to changes in the high latitudes of the Southern Hemisphere.

Stein (1985a) noted a decreased opal flux at Site 397 on the northwest African margin after $0.5 \mathrm{Ma}$ (see also results from Site 658 in Tiedemann et al., this vol.). Stein noted that this change could be attributed either to reduced fluvial delivery of nutrients due to aridification of northwest Africa or to a lower silica content of upwelled waters. As noted earlier, opal fluxes along the continental margin are probably controlled by factors different from those along the equator.

\section{Late Pleistocene Decrease in Terrigenous Dust}

Terrigenous dust fluxes decreased by as much as half in the last 0.7 m.y. at both equatorial locations (Figs. 7 and 8). If the decreases are real, they require either reduced dust availability in tropical North Africa or reduced transport to the equatorial Atlantic.

In general, evidence from North Africa favors increasing aridity over the last $0.7 \mathrm{~m}$.y. Dupont et al. (this vol.) found a trend toward pollen taxa indicative of increasingly arid glacials and interglacials during the last $0.5 \mathrm{~m}$.y. Tiedemann et al. (this vol.) found slowly increasing influxes of siliciclastic sediment during the same interval, suggesting slowly increasing aridity over Sahelian Africa (see also Stein, 1985b). Thus, the basic late Pleistocene trend in Africa appears to be toward greater aridity. This should enhance dust fluxes unless the climate becomes one of continually hyperarid conditions; the late Pleistocene alternations observed between wetter and drier climates (Street-Perrott and Harrison, 1984) argue against continual hyperaridity. Thus, evidence for long-term aridification of Africa opposes the decreased winter-plume dust fluxes after $0.47 \mathrm{Ma}$.

There is scattered evidence suggesting that aridification is not the only long-term trend in Africa during the late Pleistocene. Oscillatory increases in the accumulation of terrestrial organic carbon, clay, and feldspar at Site 658 have been interpreted as indications of periodically increased influxes of river sediments (Stein et al., this vol.; Tiedemann et al., this vol.). These alternated with evidence of increased aridity, suggesting that the amplitude of cycles of aridity and humidity increased in the late Pleistocene. Jansen et al. (1984) found intervals of lower accumulation rates of terrigenous sediment on the Zaire Fan during the last $350,000 \mathrm{yr}$ and noted that one possible interpretation is a shift to more humid climates in the Zaire basin in south equatorial Africa. At present, there are too few land-based records to characterize aridity trends in Africa over the last $500,000 \mathrm{yr}$.

Another possibility is that changes in atmospheric circulation diminished the influence of the winter dust plume at the equator by redirecting the dust flux somewhat farther north. Siliciclastic fluxes increased during the late Pleistocene in the low-resolution record at Site 660 , which is located within the winter dust plume (Tiedemann et al., this vol.). This could indicate a partial redirection of the winter dust plume away from the equator.

As with the late Pleistocene opal fluxes discussed above, the ultimate explanations for the decreased terrigenous dust fluxes may lie in changes of Northern Hemisphere ice volume, with more immediate control by changes in circumantarctic circulation.

\section{Gradual Flux Trends over the Last 3.5 M.Y.}

There are three factors that could contribute to the very gradual trends over the last 3.5 m.y.: (1) plate tectonics, (2) seafloor subsidence, and (3) tectonic uplift.

Over long time intervals, the northward drift of the Atlantic seafloor due to plate tectonics can impact fluxes to equatorial Atlantic sediments (Stein, 1985b). The rate of motion has been estimated at about $0.25^{\circ}$ of latitude $(25 \mathrm{~km})$ per m.y. (Sclater et al., 1977). Over the last 3.5 m.y., however, this effect should be small, because less than $1^{\circ}$ of plate motion has occurred beneath the relatively gentle lateral gradients in surface-ocean productivity (EQUALANT, 1973), biosiliceous deposition (Pokras and Molfino, 1986), and atmospheric dust load (Prospero, 1981). 
Seafloor subsidence (Sclater et al., 1977) could lead to gradual increases in dissolution and reduced fluxes of $\mathrm{CaCO}_{3}$ at these sites. The age of the crust under all three equatorial sites is about $10 \mathrm{Ma}$. Subsidence curves predict a total of roughly $1000 \mathrm{~m}$ of total seafloor deepening, with about $200 \mathrm{~m}$ in the last $3.5 \mathrm{~m} . \mathrm{y}$. The major decrease in $\mathrm{CaCO}_{3}$ flux occurs in the youngest part of the record when subsidence was slowest, but subsidence might still be a factor if the most recent increases in depth led to initial contact with the top of the lysocline.

Tectonic uplift can also effect long-term trends, as summarized in the paleoenvironmental synthesis (Ruddiman et al., this vol.). There is ample evidence for a large-scale uplift of the Tibetan Plateau during the late Cenozoic, with as much as a doubling of mean elevation during the last 5 m.y. (Mercier et al., 1987). The GCM experiments show that Tibetan uplift not only increases the strength of the monsoon circulation in India and Asia (Manabe and Terpstra, 1974), but it also causes substantial increases in aridity over northern and eastern Africa (Kutzbach et al., in press).

Thus, the gradual uplift of Tibet predicts a slow increase in aridity in northern and eastern Africa, and probably in the central Sahara region as well (Ruddiman et al., this vol.). This increase in aridity may contribute to the slow background increase in percentages of terrigenous dust visible at both equatorial sites (Figs. 5 and 6). It is also consistent with the slowly increasing accumulation rate of terrigenous dust at both sites from 3.6 to $0.8 \mathrm{Ma}$ (Figs. 7 and 8 ), but not with the rather abrupt decrease since that time. The steady long-term increase in dust fluxes is also visible at Leg 108 sites in the summer dust plume farther north (Tiedemann et al., this vol.).

The lack of a really persuasive background increase in dust flux at Site 664 (and perhaps Site 662) prior to about 2.5 Ma may also have a tectonic explanation. The uplift experiments predict an increase in moisture in tropical western Africa and the southwestern Sahel (see the paleoenvironmental synthesis in Ruddiman et al., this vol.). Increased moisture in this part of the winter-plume source area may have offset the drying underway elsewhere in North Africa.

\section{SUMMARY}

The mean flux of opal at equatorial Atlantic Sites 662 and 664 increased abruptly by $60 \%-70 \%$ near $2.5 \mathrm{Ma}$, with stronger increases during shorter-term pulses of opal deposition. This increase suggests the initiation of a periodically stronger zonal component of southern trade-wind flow along the equator during Southern Hemisphere winter. This change in circulation may be ultimately linked to the appearance of Northern Hemisphere ice sheets, but it is probably driven via the intermediary of major circulation changes in the Southern Ocean.

The mean flux of winter-plume dust from North Africa also increased abruptly (by $35 \%-75 \%$ ) near $2.5 \mathrm{Ma}$, with shorter pulses of stronger influx also evident since that time. This increase suggests periodically increased aridity and dust availability in North African source areas for winter-plume dust, possibly accompanied by periodically increased transport by low-level easterly winds. Increased aridity in winter-plume source areas implies a weaker meridional monsoonal flow into Africa during the Northern Hemisphere summer, consistent with the stronger zonal flow of southern trade winds deduced from opal deposition.

The decreased deposition of $\mathrm{CaCO}_{3}$, opal, and terrigenous dust after 0.8 Ma may be an artifact of changes in local sediment redistribution or may reflect changes in deep-water flow, equatorial winds and surface-water productivity, and African aridity, respectively.

A slow background increase in the deposition of terrigenous dust during the late Pliocene and early-middle Pleis- tocene may reflect gradual aridification of northern and eastern Africa due to the slow uplift of Tibet and the consequent alteration of low-level and upper easterly winds.

\section{ACKNOWLEDGMENTS}

We thank Wayne Riley, Linda Baker, and Pat Malone for laboratory work; Christina Hardy for data entry; Ann Esmay for data analysis and figure plotting; Flip Froelich, Connie Sancetta, and Peter Demenocal for in-house manuscript review; and Michael Sarnthein and an anonymous reviewer for other reviews. This research was funded partly from USSAC proposal TAMRF PO \#77351 and partly from Grant OCE-8608238 from the Marine Geology and Geophysics Program of the National Science Foundation. This is Lamont-Doherty Geological Observatory Contribution No. 4403.

\section{REFERENCES}

Backman, J., 1979. Pliocene biostratigraphy of DSDP Sites 111 and 116 from the North Atlantic Ocean and the age of Northern Hemisphere Glaciation. Stockholm Contrib. Geol., 32:115-137.

Bonnefille, R., 1983. Evidence for a cooler and drier climate in the Ethiopian Highlands towards 2.5 m.y. ago. Nature, 303:487-491. 1985. Evolution of the continental vegetation: the paleobotanical record from East Africa. S. Afr. J. Sci., 81:267-270.

Boyle, E. A., and Keigwin, L. D., 1985. Comparison of Atlantic and Pacific paleochemical records for the last 215,000 years: changes in deep ocean circulation and chemical inventories. Earth Planet. Sci. Lett., 76:135-150.

Broecker, W. S., and Peng, T.-H., 1982. Tracers in the Sea: Palisades, NY (Eldigio Press).

Cieselski, P. F., and Grinstead, G. P., 1986. Pliocene variations in the position of the antarctic convergence in the southwest Atlantic. Paleoceanography, 1:197-232.

Curry, W. B., and Lohman, G. P., 1986. Late Quaternary carbonate sedimentation at the Sierra Leone Rise (eastern equatorial Atlantic Ocean). Mar. Geol., 70:223-250.

Dymond, J., and Lyle, M., 1985. Flux comparisons between sediments and sediment traps in the eastern tropical Pacific: implications for atmospheric $\mathrm{C} 02$ variations during the Pleistocene. Limnol. Oceanogr., 30:699-712.

EQUALANT, 1973. In Oceanographic Atlas, EQUALANT I and EQUALANT II (Vol. II: Physical Oceanography): Paris (UNESCO).

Fütterer, D., 1978. Late Neogene silt at the Sierra Leone Rise (Leg 41 Site 366): terrigenous and biogenous components. In Lancelot, Y., Seibold, E., et al., Init. Repts. DSDP, 41: Washington (U.S. Govt. Printing Office), 1049-1059.

Gardner, J. V., 1975. Late Pleistocene carbonate dissolution cycles in the eastern equatorial Atlantic. In Sliter, W. V., Bé, A.W.H., and Berger, W. H. (Eds.), Dissolution of Deep-Sea Carbonates. Spec. Publ., Cushman Found. Foraminiferal Res., 13:129-141

Gardner, J. V., and Hays, J. D., 1976. Responses of sea-surface temperature and circulation to global climatic change during the past 200,000 years in the eastern equatorial Atlantic ocean. In Cline, R. M., and Hays, J. D. (Eds.), Investigation of Late Quaternary Paleoceanography and Paleoclimatology. Mem. Geol. Soc. Am., 145:221-247.

Hays, J. D., 1967. Quaternary sediments of the Antarctic Ocean. Prog. Oceanogr., 4:117-131.

Imbrie, J., Hays, J. D., Martinson, D. G., McIntyre, A., Mix, A., Morley, J. J., Pisias, N. G., Prell, W. L., and Shackelton, N. J., 1984. The orbital theory of Pleistocene climate: support from a revised chronology of the marine $\delta^{18} \mathrm{O}$ record. In Berger, A. L., Imbrie, J., Hays, J., Kukla, G., and Saltzman, B. (Eds.), Milankovitch and Climate (Pt. 1): Dordrecht (D. Reidel), 269-305.

Janecek, T. R., 1985. The Brunhes record of terrigenous (eolian) input into the equatorial Atlantic Ocean. Geol. Soc. Am., Abstr. Annu. Meet., p. 618

Jansen, J. H. F., van Weering, T. C. E., Gieles, R., and van Iperen, J., 1984. Middle and late Quaternary oceanography and climatology of the Zaire-Congo Fan and the adjacent eastern Angola Basin. Neth. J. Sea Res., 17:201-249.

Jones, G. A., and Kaiteris, P., 1983. A vacuum-gasometric technique for rapid and precise analysis of calcium carbonate in sediments and soils. J. Sediment. Petrol., 53:655-660. 
Joussaume, S., and Sadourny, R., 1987. Desert dust and climate: investigation using an atmospheric general circulation model. In NATO Advanced Research Workshop Paleoclimatology and Paleometeorology, Abstr. of Proceedings.

Keany, J., and Kennett, J. P., 1972. Pliocene-early Pleistocene paleoclimatic history recorded in antarctic-subantarctic deep-sea cores. Deep-Sea Res., 19:529-548.

Kutzbach, J. E., 1981. Monsoon climate of the early Holocene: climatic experiment using the earth's orbital parameters for 9000 years ago. Science, 214:59-61.

Kutzbach, J. E., Guetter, P., Prell, W. L., and Ruddiman, W. F., in press. The sensitivity of climate to late Cenozoic uplift of the Tibetan and Colorado Plateaus: numerical experiments. J. Geophys. Res.

Kutzbach, J. E., and Street-Perrott, F. A., 1985. Milankovitch forcing of fluctuations in the level of tropical lakes from 18 to $0 \mathrm{kyr}$ BP. Nature, 317:130-134.

Labracherie, M., 1980. Les radiolares temoins de l'evolution hydrologique depuis le dernier maximum glaciaire au large de Cap Blanc (Afrique du Nord-Ouest). Palaeogeogr., Palaeoclimatol., Palaeoecol., 32:163-184.

Lyle, M., Murray, D. W., Finney, B. P., Dymond, J., Robbins, J. M., and Brooksforce, K., 1988. The record of late Pleistocene biogenic sedimentation in the eastern tropical Pacific Ocean. Paleoceanography, 3:39-60.

Manabe, S., and Terpstra, T. B., 1974. The effects of mountains on the general circulation of the atmosphere as identified by numerical experiments. J. Atmos. Sci., 31:3-42.

Mankinen, E. A., and Dalrymple, G. B., 1979. Revised geomagnetic polarity time-scale for the interval 0-5 m.y. B.P. J. Geophys. Res., $84: 615-626$.

McDonald, W. F., 1938. Atlas of Climatic Charts of the Oceans: Washington (Dept. of Agriculture, Weather Bureau).

McIntyre, A., Ruddiman, W. F., Karlin, K., and Mix, A. C., 1989. Surface water response of the equatorial Atlantic Ocean to orbital forcing. Paleoceanography, 4:19-55.

Mead, G. A., Hodell, D. A., and Cieselski, P. F., 1988. Southern Ocean response to the onset of Northern Hemisphere glaciation at 2.4 Ma. Geol. Soc. Am., Abstr. Annu. Meet., p. A252.

Mercier, J.-L., Armijo, R., Tapponnier, P., Carey-Gailhardis, E., and Lin, H. T., 1987. Change from late Tertiary compression to Quaternary extension in southern Tibet during the India-Asia collision. Tectonics, 6:275-304.

Mix, A. C., and Fairbanks, R. G., 1985. North Atlantic surface-ocean control of Pleistocene deep-ocean circulation. Earth Planet. Sci. Lett., 73:231-243.

Mix, A. C., and Ruddiman, W. F., 1986. Structure and timing of the last deglaciation: oxygen-isotope evidence. Quat. Sci. Rev., 4:59108.

Mix, A. C., Ruddiman, W. F., and McIntyre, A., 1986. Late Quaternary paleoceanography of the tropical Atlantic, 1: spatial variability of annual mean sea-surface temperatures, $0-20,000 \mathrm{yr}$ B.P. Paleoceanography, 1:43-66.

Mortlock, R. A., and Froelich, P. M., in press. A simple method for the rapid determination of biogenic opal in deep-sea sediments. Deep-Sea Res.

Nicholson, S. E., and Flohn, H., 1980. African environmental and climatic changes and the general atmosphere circulation in late Pleistocene and Holocene. Clim. Change, 2:313-348.

Oppo, D., and Fairbanks, R. G., 1987. Variability in the deep and intermediate water circulation of the Atlantic Ocean during the past 25,000 years: Northern Hemisphere modulation of the Southern Ocean. Earth Planet. Sci. Lett., 86:1-15.

Parkin, D. W., and Padgham, R. C., 1975. Further studies on trade winds during the glacial cycles. Proc. Trans. R. Soc. London, Ser. A, 346:245-260.

Pastouret, L., Chamley, H., Delibrias, G., Duplessy, J. C., and Thiede, J., 1978. Late Quaternary climatic changes in western tropical Africa deduced from deep-sea sedimentation off the Niger delta. Oceanol. Acta, 1:217-232.

Pflaumann, U., 1986. Sea-surface temperatures during the last 750,000 years in the eastern equatorial Atlantic: planktonic foraminiferal record of "Meteor" cores 13519, 13521, and 16415. Meteor Forschungsergeb., Reihe C, 40:137-161.
Pisias, N. G., and Moore, T. C., 1981. The evolution of Pleistocene climate: a time series approach. Earth Planet. Sci. Lett., 52:450-458.

Pokras, E. M., 1987. Diatom record of late Quaternary climatic change in the eastern equatorial Atlantic and tropical Africa. Paleoceanography, 2:273-286.

Pokras, E. M., and Mix, A. C., 1985. Eolian evidence for spatial variability of late Quaternary climates in tropical Africa. Quat. Res., 24:137-149.

1987. Earth's precession cycle and Quaternary climatic change in tropical Africa. Nature, 326:486-487.

Pokras, E. M., and Molfino, B., 1986. Oceanographic control of diatom abundances and species distributions in surface sediments of the tropical and southeast Atlantic. Mar. Micropaleontol., 10:165-188.

Prell, W. L., 1982. Oxygen and carbon isotope stratigraphy for the Quaternary of Hole 502B: evidence for two modes of isotopic variability. In Prell, W. L., Gardner, J. V., et al., Init. Repts. DSDP, 68: Washington (U.S. Govt. Printing Office), 455-464.

Prospero, J. M., 1981. Arid regions as sources of mineral aerosols in the marine environment. In Pewe, T. L. (Ed.), Desert Dust: Origins, Characteristics, and Effects on Man. Geol. Soc. Am. Spec. Pap., 186:71-86.

Raymo, M. E., Ruddiman, W. F., Backman, J., Clement, B. M., and Martinson, D. G., in press. Late Pliocene variation in Northern Hemisphere ice sheets and North Atlantic deep circulation. $\mathrm{Pa}$ leoceanography.

Ruddiman, W. F., Raymo, M. E., and McIntyre, A., 1986. Matuyama 41,000-yr cycles: North Atlantic Ocean and Northern Hemisphere ice sheets. Earth Planet. Sci. Lett., 80:117-129.

Ruddiman, W. F., Raymo, M. E., Martinson, D. G., Clement, B. M., and Backman, J., in press. Pleistocene evolution of Northern Hemisphere climate. Paleoceanography.

Ruddiman, W. F., Sarnthein, M., et al., 1988. Init. Repts. ODP, 108: College Station, TX (Ocean Drilling Program).

Sarnthein, M. S., 1978. Sand deserts during glacial maximum and climatic optimum. Nature, 272:43-46.

Sarnthein, M., Thiede, J., Pflaumann, U., Erlenkeuser, H., Fütterer, D., Koopman, B., Lange, H., and Seibold, E., 1982. Atmospheric and oceanic circulation patterns off northwest Africa during the past 25 million years. In von Rad, U., Hinz, K., Sarnthein, M. and Seibold, E. (Eds.), Geology of the Northwest African Continental Margin: Berlin-Heidelberg-New York (Springer-Verlag), $545-604$.

Sclater, J. G., Hellinger, S., and Tapscott, C., 1977. The paleobathymetry of the Atlantic Ocean from the Jurassic to the Recent. J. Geol., 85:509-522.

Shackleton, N. J., and Hall, M. A., 1983. Stable isotope record of Hole 504 sediments: high resolution record of the Pleistocene. In Cann, J., Langseth, M., et al., Init. Repts. DSDP, 69: Washington (U.S. Govt. Printing Office), 431-441.

Shackleton, N. J., Backman, J., Zimmerman, H., Kent, D. V., Hall, M. A., Roberts, D. G., Schnitker, D., Baldauf, J. G., Desprairies, A., Homrighausen, R., Huddlestun, P., Keene, J. B., Kaltenback, A. J., Krumsiek, K.A.O., Morton, A. C., Murray, J. W., and Westberg-Smith, J., 1984. Oxygen isotope calibration of the onset of ice rafting: history of glaciation in the North Atlantic region. Nature, 307:620-623.

Stabell, B., 1986. Variations of diatom flux in the eastern equatorial Atlantic during the last 400,000 years ("Meteor" cores 13519 and 13521). Mar. Geol., 72:305-323.

Stein, R., 1985a. Late Neogene changes of paleoclimate and paleoproductivity off northwest Africa (DSDP Site 397). Palaeogeogr., Palaeoclimatol., Palaeoecol., 49:47-59.

1985b. The post-Eocene sediment record of DSDP Site 366 implications for African climate and plate tectonic drift. Mem. Geol. Soc. Am., 163:305-315.

1986. Late Neogene evolution of paleoclimate and paleoceanic circulation in the Northern and Southern Hemispheres-a comparison. Geol. Rundsch., 75:125-138.

Stein, R., and Sarnthein, M., 1984. Late Neogene events of atmospheric and oceanic circulation offshore northwest Africa: high-resolution record from deep-sea sediments. Palaeoecol. Afr., 16:9-36.

Street-Perrott, F. A., and Harrison, S. P., 1984. Temporal variations in lake levels since $30,000 \mathrm{yr}$ B.P. - an index of the global 
hydrological cycle. In Hansen, J. E., and Takahashi, T. (Eds.), Climate Processes and Sensitivity: Washington (American Geophysical Union). Geophys. Monogr. Ser., 29:118-129.

Thierstein, H. R., Geitzenauer, K. R., Molfino, B., and Shackleton, N. J., 1977. Global synchroneity of late Pleistocene coccolith datum levels: validation by oxygen isotopes. Geology, 5:400-404.

Vrba, E. S., 1985. African Bovidae: evolutionary events since the Miocene. S. Afr. J. Sci., 81:263-266.

Wesselman, H. B., 1985. Fossil micromammals and indicators of climatic change about $2.4 \mathrm{~m} . y$. ago in the Omo Valley, Ethiopia. $S$. Afr. J. Sci., 81:260-261.

Date of initial receipt: 2 March 1988

Date of acceptance: 12 February 1989 Ms 108B-165

Table 4 Percentages of carbonate, opal, and terrigenous fraction, and dry-bulk densities at Hole 662A.

\begin{tabular}{|c|c|c|c|c|c|}
\hline $\begin{array}{l}\text { Core, section, } \\
\text { interval }(\mathrm{cm})\end{array}$ & $\begin{array}{l}\text { Depth } \\
\text { (mbsf) }\end{array}$ & $\underset{(\%)}{\mathrm{CaCO}_{3}}$ & $\underset{(\%)}{\mathrm{SiO}_{2}}$ & $\begin{array}{c}\text { Terrigenous } \\
\text { fraction } \\
(\%)\end{array}$ & $\begin{array}{c}\text { Dry-bulk } \\
\text { density } \\
\left(\mathrm{g} / \mathrm{cm}^{3}\right)\end{array}$ \\
\hline $108-662 \mathrm{~A}-13 \mathrm{H}-1,29$ & 107.98 & 86.6 & 3.0 & 10.4 & 0.87 \\
\hline $108-662 \mathrm{~A}-13 \mathrm{H}-1,41$ & 108.11 & 85.6 & 3.3 & 11.1 & \\
\hline $108-662 \mathrm{~A}-13 \mathrm{H}-1,50$ & 108.20 & 87.6 & & & \\
\hline $108-662 \mathrm{~A}-13 \mathrm{H}-1,59$ & 108.29 & 84.6 & 4.0 & 11.4 & 1.05 \\
\hline $108-662 \mathrm{~A}-13 \mathrm{H}-1,71$ & 108.41 & 77.1 & 5.1 & 17.9 & 0.95 \\
\hline $108-662 \mathrm{~A}-13 \mathrm{H}-1,79$ & 108.48 & 81.1 & 4.7 & 14.2 & 0.84 \\
\hline $108-662 \mathrm{~A}-13 \mathrm{H}-1,89$ & 108.58 & 81.7 & 5.2 & 13.1 & 1.08 \\
\hline $108-662 \mathrm{~A}-13 \mathrm{H}-1,101$ & 108.70 & 83.0 & 5.0 & 12.0 & 0.98 \\
\hline $108-662 \mathrm{~A}-13 \mathrm{H}-1,110$ & 108.79 & 85.3 & & & \\
\hline $108-662 \mathrm{~A}-13 \mathrm{H}-1,117$ & 108.86 & 89.7 & 3.0 & 7.3 & 1.01 \\
\hline $108-662 A-13 H-1,131$ & 109.01 & 91.0 & 2.7 & 6.3 & 1.02 \\
\hline $108-662 \mathrm{~A}-13 \mathrm{H}-1,139$ & 198.08 & 83.6 & 2.9 & 13.5 & 0.84 \\
\hline $108-662 \mathrm{~A}-13 \mathrm{H}-1,146$ & 109.16 & 82.6 & 1.8 & 15.6 & 1.03 \\
\hline $108-662 \mathrm{~A}-13 \mathrm{H}-2,11$ & 109.31 & 88.7 & 3.2 & 8.1 & 0.94 \\
\hline $108-662 \mathrm{~A}-13 \mathrm{H}-2,19$ & 109.39 & 84.4 & 5.2 & 10.4 & 0.80 \\
\hline $108-662 \mathrm{~A}-13 \mathrm{H}-2,29$ & 109.48 & 81.3 & 5.7 & 13.0 & 0.94 \\
\hline $108-662 \mathrm{~A}-13 \mathrm{H}-2,41$ & 109.61 & 83.5 & 4.6 & 11.9 & 1.04 \\
\hline $108-662 \mathrm{~A}-13 \mathrm{H}-2,50$ & 109.70 & 87.0 & & & \\
\hline $108-662 \mathrm{~A}-13 \mathrm{H}-2,59$ & 109.79 & 88.4 & 3.0 & 8.6 & 1.11 \\
\hline $108-662 \mathrm{~A}-13 \mathrm{H}-2,71$ & 109.91 & 85.9 & 4.3 & 9.8 & 1.05 \\
\hline $108-662 \mathrm{~A}-13 \mathrm{H}-2,79$ & 109.98 & 81.2 & 4.8 & 13.9 & 0.86 \\
\hline $108-662 \mathrm{~A}-13 \mathrm{H}-2,89$ & 110.08 & 81.8 & 4.3 & 13.9 & 1.02 \\
\hline 108-662A-13H-2, 101 & 110.20 & 77.1 & 6.0 & 17.0 & 1.02 \\
\hline $108-662 \mathrm{~A}-13 \mathrm{H}-2,110$ & 110.29 & 86.7 & & & \\
\hline $108-662 \mathrm{~A}-13 \mathrm{H}-2,119$ & 110.39 & 87.3 & 3.8 & 8.9 & 1.04 \\
\hline $108-662 \mathrm{~A}-13 \mathrm{H}-2,131$ & 110.51 & 88.3 & 3.7 & 8.0 & 1.13 \\
\hline $108-662 \mathrm{~A}-13 \mathrm{H}-2,139$ & 110.58 & 88.5 & 5.1 & 6.5 & 0.82 \\
\hline $108-662 \mathrm{~A}-13 \mathrm{H}-3,146$ & 110.66 & 88.1 & 4.2 & 7.7 & 1.02 \\
\hline $108-662 \mathrm{~A}-13 \mathrm{H}-3,11$ & 110.81 & 88.8 & 3.4 & 7.7 & 1.02 \\
\hline $108-662 \mathrm{~A}-13 \mathrm{H}-3,19$ & 110.89 & 88.5 & 3.8 & 7.7 & 0.82 \\
\hline $108-662 \mathrm{~A}-13 \mathrm{H}-3,29$ & 110.98 & 89.2 & 3.5 & 7.3 & 0.98 \\
\hline $108-662 \mathrm{~A}-13 \mathrm{H}-3,41$ & 111.11 & 88.5 & 3.5 & 8.0 & 1.25 \\
\hline $108-662 \mathrm{~A}-13 \mathrm{H}-3,50$ & 111.20 & 86.8 & & & \\
\hline $108-662 \mathrm{~A}-13 \mathrm{H}-3,59$ & 111.29 & 89.6 & 3.4 & 7.1 & 1.06 \\
\hline $108-662 \mathrm{~A}-13 \mathrm{H}-3,71$ & 111.41 & 88.8 & 3.8 & 7.5 & 1.14 \\
\hline $108-662 \mathrm{~A}-13 \mathrm{H}-3,79$ & 111.48 & 89.9 & 2.4 & 7.7 & 0.86 \\
\hline $108-662 \mathrm{~A}-13 \mathrm{H}-3,89$ & 111.58 & 88.7 & 3.2 & 8.1 & 0.94 \\
\hline $108-662 \mathrm{~A}-13 \mathrm{H}-3,101$ & 111.70 & 84.3 & 3.7 & 12.0 & 1.06 \\
\hline $108-662 \mathrm{~A}-13 \mathrm{H}-3,110$ & 111.79 & 87.6 & & & \\
\hline $108-662 \mathrm{~A}-13 \mathrm{H}-3,119$ & 111.89 & 71.2 & 7.4 & 21.4 & 0.94 \\
\hline $108-662 \mathrm{~A}-13 \mathrm{H}-3,131$ & 112.01 & 76.1 & 6.6 & 17.3 & 0.97 \\
\hline $108-662 \mathrm{~A}-13 \mathrm{H}-3,139$ & 112.08 & 74.4 & 7.1 & 18.4 & 0.79 \\
\hline $108-662 \mathrm{~A}-13 \mathrm{H}-3,145$ & 112.16 & 77.8 & 7.2 & 15.1 & 0.97 \\
\hline $108-662 \mathrm{~A}-13 \mathrm{H}-4,11$ & 112.31 & 62.5 & 9.5 & 28.1 & 0.90 \\
\hline $108-662 \mathrm{~A}-13 \mathrm{H}-4,19$ & 112.39 & 71.9 & 7.6 & 20.5 & 0.81 \\
\hline $108-662 A-13 H-4,29$ & 112.48 & 77.2 & 6.6 & 16.2 & 1.03 \\
\hline $108-662 \mathrm{~A}-13 \mathrm{H}-4,41$ & 112.61 & 64.8 & 7.6 & 27.6 & 1.05 \\
\hline $108-662 \mathrm{~A}-13 \mathrm{H}-4,50$ & 112.70 & 82.9 & & & \\
\hline $108-662 \mathrm{~A}-13 \mathrm{H}-4,59$ & 112.79 & 66.1 & 5.1 & 28.8 & 1.17 \\
\hline $108-662 \mathrm{~A}-13 \mathrm{H}-4,71$ & 112.91 & 72.2 & 3.0 & 24.8 & 1.41 \\
\hline $108-662 \mathrm{~A}-13 \mathrm{H}-4,79$ & 112.98 & 85.9 & 3.1 & 11.0 & 0.89 \\
\hline $108-662 \mathrm{~A}-13 \mathrm{H}-4,89$ & 113.08 & 79.0 & 5.8 & 15.2 & 1.01 \\
\hline $108-662 \mathrm{~A}-13 \mathrm{H}-4,101$ & 113.20 & 77.3 & 6.4 & 16.3 & 1.01 \\
\hline $108-662 \mathrm{~A}-13 \mathrm{H}-4,110$ & 113.29 & 67.1 & & & \\
\hline
\end{tabular}

Table 4 (continued).

\begin{tabular}{|c|c|c|c|c|c|}
\hline $\begin{array}{l}\text { Core, section, } \\
\text { interval }(\mathrm{cm})\end{array}$ & $\begin{array}{l}\text { Depth } \\
\text { (mbsf) }\end{array}$ & $\begin{array}{c}\mathrm{CaCO}_{3} \\
(\%)\end{array}$ & $\begin{array}{c}\mathrm{SiO}_{2} \\
(\%)\end{array}$ & $\begin{array}{l}\text { Terrigenous } \\
\text { fraction } \\
(\%)\end{array}$ & $\begin{array}{c}\text { Dry-bulk } \\
\text { density } \\
\left(\mathrm{g} / \mathrm{cm}^{3}\right)\end{array}$ \\
\hline $108-662 \mathrm{~A}-13 \mathrm{H}-4,119$ & 113.39 & 68.1 & 7.9 & 24.0 & 1.01 \\
\hline $108-662 \mathrm{~A}-13 \mathrm{H}-4,131$ & 113.51 & 69.2 & 7.9 & 22.9 & 1.37 \\
\hline $108-662 \mathrm{~A}-13 \mathrm{H}-4,139$ & 113.58 & 69.7 & 8.1 & 22.2 & 0.79 \\
\hline $108-662 \mathrm{~A}-13 \mathrm{H}-4,145$ & 113.66 & 77.3 & 5.9 & 16.7 & 1.00 \\
\hline $108-662 \mathrm{~A}-13 \mathrm{H}-5,11$ & 113.81 & 80.4 & 4.0 & 15.6 & 1.56 \\
\hline $108-662 \mathrm{~A}-13 \mathrm{H}-5,19$ & 113.89 & 88.8 & 3.7 & 7.5 & 0.91 \\
\hline $108-662 \mathrm{~A}-13 \mathrm{H}-5,29$ & 113.98 & 86.9 & 2.7 & 10.4 & 1.12 \\
\hline $108-662 \mathrm{~A}-13 \mathrm{H}-5,41$ & 114.11 & 89.5 & 2.7 & 7.8 & 1.06 \\
\hline $108-662 \mathrm{~A}-13 \mathrm{H}-5,50$ & 114.20 & 80.3 & & & \\
\hline $108-662 \mathrm{~A}-13 \mathrm{H}-5,59$ & 114.29 & 67.5 & 6.9 & 25.6 & 1.02 \\
\hline $108-662 \mathrm{~A}-13 \mathrm{H}-5,71$ & 114.41 & 83.7 & 7.1 & 9.2 & 1.02 \\
\hline $108-662 \mathrm{~A}-13 \mathrm{H}-5,79$ & 114.48 & 69.1 & 9.3 & 21.6 & 0.79 \\
\hline $108-662 \mathrm{~A}-13 \mathrm{H}-5,89$ & 114.58 & 71.8 & 8.9 & 19.3 & 1.01 \\
\hline $108-662 \mathrm{~A}-13 \mathrm{H}-5,101$ & 114.70 & 71.8 & 9.0 & 19.2 & 0.99 \\
\hline $108-662 \mathrm{~A}-13 \mathrm{H}-5,110$ & 114.79 & 73.8 & & & \\
\hline $108-662 \mathrm{~A}-13 \mathrm{H}-5,115$ & 114.85 & 71.5 & 8.2 & 20.3 & 0.79 \\
\hline $108-662 \mathrm{~A}-13 \mathrm{H}-5,120$ & 114.90 & 72.2 & & & \\
\hline $108-662 \mathrm{~A}-13 \mathrm{H}-5,131$ & 115.01 & 69.1 & 8.1 & 22.9 & 1.07 \\
\hline $108-662 \mathrm{~A}-13 \mathrm{H}-5,139$ & 115.08 & 84.1 & 5.0 & 10.9 & 0.88 \\
\hline $108-662 \mathrm{~A}-13 \mathrm{H}-5,145$ & 115.16 & 87.4 & 3.2 & 9.3 & 1.10 \\
\hline $108-662 \mathrm{~A}-13 \mathrm{H}-6,7$ & 115.27 & 86.3 & 4.0 & 9.7 & 1.11 \\
\hline $108-662 \mathrm{~A}-13 \mathrm{H}-6,19$ & 115.39 & 89.4 & 3.0 & 7.6 & 0.87 \\
\hline $108-662 \mathrm{~A}-13 \mathrm{H}-6,29$ & 115.48 & 89.3 & 3.1 & 7.6 & 1.06 \\
\hline $108-662 \mathrm{~A}-13 \mathrm{H}-6,41$ & 115.61 & 88.1 & 2.8 & 9.1 & 1.12 \\
\hline $108-662 \mathrm{~A}-13 \mathrm{H}-6,50$ & 115.70 & 88.6 & & & \\
\hline $108-662 \mathrm{~A}-13 \mathrm{H}-6,59$ & 115.79 & 87.7 & 4.9 & 7.4 & 1.00 \\
\hline $108-662 \mathrm{~A}-13 \mathrm{H}-6,71$ & 115.91 & 83.9 & 5.2 & 10.9 & 1.06 \\
\hline $108-662 \mathrm{~A}-13 \mathrm{H}-6,79$ & 115.98 & 87.7 & 4.5 & 7.8 & 0.86 \\
\hline $108-662 \mathrm{~A}-13 \mathrm{H}-6,89$ & 116.08 & 88.0 & 3.6 & 8.4 & 1.01 \\
\hline $108-662 \mathrm{~A}-13 \mathrm{H}-6,101$ & 116.20 & 88.8 & 3.7 & 7.5 & 1.07 \\
\hline $108-662 \mathrm{~A}-13 \mathrm{H}-6,110$ & 116.29 & 88.1 & & & \\
\hline $108-662 \mathrm{~A}-13 \mathrm{H}-6,115$ & 116.35 & 87.8 & 4.1 & 8.1 & 1.08 \\
\hline $108-662 \mathrm{~A}-13 \mathrm{H}-6,118$ & 116.38 & 87.7 & & & \\
\hline $108-662 \mathrm{~A}-13 \mathrm{H}-6,131$ & 116.51 & 87.2 & 4.1 & 8.7 & 1.07 \\
\hline $108-662 \mathrm{~A}-13 \mathrm{H}-6,139$ & 116.58 & 86.4 & 3.8 & 9.8 & 0.93 \\
\hline $108-662 \mathrm{~A}-13 \mathrm{H}-6,146$ & 116.66 & 86.2 & 4.1 & 9.7 & 1.16 \\
\hline $108-662 \mathrm{~A}-13 \mathrm{H}-7,11$ & 116.81 & 77.5 & 6.4 & 16.1 & 1.08 \\
\hline $108-662 \mathrm{~A}-13 \mathrm{H}-7,19$ & 116.89 & 78.1 & 6.7 & 15.2 & 0.88 \\
\hline $108-662 \mathrm{~A}-13 \mathrm{H}-7,29$ & 116.98 & 75.6 & 6.6 & 17.8 & 1.07 \\
\hline $108-662 \mathrm{~A}-13 \mathrm{H}-7,41$ & 117.11 & 79.9 & 6.2 & 13.9 & 1.11 \\
\hline $108-662 \mathrm{~A}-13 \mathrm{H}-7,50$ & 117.20 & 66.3 & & & \\
\hline $108-662 \mathrm{~A}-13 \mathrm{H}-7,54$ & 117.24 & 64.4 & 8.2 & 27.4 & 1.06 \\
\hline $108-662 \mathrm{~A}-14 \mathrm{H}-1,11$ & 117.31 & 81.5 & 4.5 & 14.0 & 1.00 \\
\hline $108-662 \mathrm{~A}-14 \mathrm{H}-1,18$ & 117.39 & 80.7 & 6.4 & 12.9 & 0.87 \\
\hline $108-662 \mathrm{~A}-14 \mathrm{H}-1,29$ & 117.49 & 82.1 & 4.8 & 13.1 & 0.83 \\
\hline $108-662 \mathrm{~A}-14 \mathrm{H}-1,41$ & 117.61 & 86.8 & 3.7 & 9.5 & 0.93 \\
\hline $108-662 \mathrm{~A}-14 \mathrm{H}-1,50$ & 117.70 & 78.9 & 4.9 & 16.2 & 1.03 \\
\hline $108-662 \mathrm{~A}-14 \mathrm{H}-1,59$ & 117.79 & 82.6 & 5.0 & 12.4 & 0.93 \\
\hline $108-662 \mathrm{~A}-14 \mathrm{H}-1,71$ & 117.91 & 75.1 & 7.5 & 17.4 & 0.82 \\
\hline $108-662 \mathrm{~A}-14 \mathrm{H}-1,79$ & 117.99 & 67.5 & 9.0 & 23.5 & 0.79 \\
\hline $108-662 \mathrm{~A}-14 \mathrm{H}-1,89$ & 118.09 & 73.6 & 7.5 & 18.9 & 0.83 \\
\hline $108-662 \mathrm{~A}-14 \mathrm{H}-1,101$ & 118.21 & 69.5 & 10.5 & 20.1 & 0.78 \\
\hline $108-662 \mathrm{~A}-14 \mathrm{H}-1,110$ & 118.30 & 67.9 & 12.1 & 20.0 & 0.84 \\
\hline $108-662 \mathrm{~A}-14 \mathrm{H}-1,119$ & 118.39 & 71.1 & 10.5 & 18.4 & 0.80 \\
\hline $108-662 \mathrm{~A}-14 \mathrm{H}-1,131$ & 118.51 & 80.8 & 10.4 & 8.7 & 0.85 \\
\hline $108-662 \mathrm{~A}-14 \mathrm{H}-1,139$ & 118.59 & 89.3 & 7.2 & 3.5 & 0.94 \\
\hline $108-662 \mathrm{~A}-14 \mathrm{H}-1,146$ & 118.66 & 86.9 & 5.3 & 7.9 & 0.98 \\
\hline $108-662 \mathrm{~A}-14 \mathrm{H}-2,11$ & 118.81 & 90.7 & 3.4 & 6.0 & 0.97 \\
\hline $108-662 \mathrm{~A}-14 \mathrm{H}-2,19$ & 118.89 & 89.3 & 2.6 & 8.1 & 1.00 \\
\hline $108-662 \mathrm{~A}-14 \mathrm{H}-2,29$ & 118.99 & 86.1 & 5.1 & 8.7 & 0.93 \\
\hline $108-662 \mathrm{~A}-14 \mathrm{H}-2,41$ & 119.11 & 77.7 & 8.2 & 14.1 & 0.82 \\
\hline $108-662 \mathrm{~A}-14 \mathrm{H}-2,50$ & 119.20 & 76.3 & 8.9 & 14.9 & 0.91 \\
\hline $108-662 \mathrm{~A}-14 \mathrm{H}-2,59$ & 119.29 & 76.4 & 8.1 & 15.6 & 0.83 \\
\hline $108-662 \mathrm{~A}-14 \mathrm{H}-2,71$ & 119.41 & 77.2 & 9.3 & 13.5 & 0.82 \\
\hline $108-662 \mathrm{~A}-14 \mathrm{H}-2,79$ & 119.49 & 86.7 & 6.1 & 7.2 & 0.86 \\
\hline $108-662 \mathrm{~A}-14 \mathrm{H}-2,89$ & 119.59 & 91.0 & 3.0 & 6.1 & 0.97 \\
\hline $108-662 \mathrm{~A}-14 \mathrm{H}-2,101$ & 119.71 & 90.0 & 3.3 & 6.8 & 0.92 \\
\hline $108-662 \mathrm{~A}-14 \mathrm{H}-2,110$ & 119.80 & 89.3 & 3.0 & 7.7 & 1.04 \\
\hline $108-662 \mathrm{~A}-14 \mathrm{H}-2,119$ & 119.89 & 89.6 & 2.8 & 7.6 & 0.97 \\
\hline $108-662 \mathrm{~A}-14 \mathrm{H}-2,131$ & 120.01 & 89.0 & 2.7 & 8.3 & 0.94 \\
\hline $108-662 \mathrm{~A}-14 \mathrm{H}-2,139$ & 120.09 & 86.9 & 3.0 & 10.1 & 0.96 \\
\hline $108-662 \mathrm{~A}-14 \mathrm{H}-2,146$ & 120.16 & 89.0 & 3.9 & 7.1 & 0.95 \\
\hline $108-662 \mathrm{~A}-14 \mathrm{H}-3,11$ & 120.31 & 86.8 & 4.6 & 8.6 & 0.90 \\
\hline $108-662 \mathrm{~A}-14 \mathrm{H}-3,19$ & 120.39 & 85.4 & 4.3 & 10.4 & 0.90 \\
\hline $108-662 \mathrm{~A}-14 \mathrm{H}-3,29$ & 120.49 & 87.1 & 3.5 & 9.5 & 0.90 \\
\hline
\end{tabular}


Table 4 (continued).

\begin{tabular}{|c|c|c|c|c|c|}
\hline $\begin{array}{l}\text { Core, section, } \\
\text { interval }(\mathrm{cm})\end{array}$ & $\begin{array}{l}\text { Depth } \\
\text { (mbsf) }\end{array}$ & $\begin{array}{c}\mathrm{CaCO}_{3} \\
(\%)\end{array}$ & $\begin{array}{c}\mathrm{SiO}_{2} \\
(\%)\end{array}$ & $\begin{array}{c}\text { Terrigenous } \\
\text { fraction } \\
(\%)\end{array}$ & $\begin{array}{c}\text { Dry-bulk } \\
\text { density } \\
\left(\mathrm{g} / \mathrm{cm}^{3}\right)\end{array}$ \\
\hline $108-662 \mathrm{~A}-14 \mathrm{H}-3,41$ & 120.61 & 89.1 & 3.3 & 7.6 & 0.91 \\
\hline $108-662 \mathrm{~A}-14 \mathrm{H}-3,50$ & 120.70 & 88.0 & 3.5 & 8.5 & 1.02 \\
\hline $108-662 \mathrm{~A}-14 \mathrm{H}-3,59$ & 120.79 & 88.3 & 3.5 & 8.2 & 0.96 \\
\hline $108-662 \mathrm{~A}-14 \mathrm{H}-3,71$ & 120.91 & 87.7 & 3.6 & 8.7 & 0.92 \\
\hline $108-662 \mathrm{~A}-14 \mathrm{H}-3,79$ & 120.99 & 87.7 & 3.8 & 8.5 & 0.93 \\
\hline $108-662 \mathrm{~A}-14 \mathrm{H}-3,89$ & 121.09 & 86.1 & 4.4 & 9.5 & 0.96 \\
\hline $108-662 \mathrm{~A}-14 \mathrm{H}-3,101$ & 121.21 & 85.1 & 4.3 & 10.5 & 0.93 \\
\hline $108-662 \mathrm{~A}-14 \mathrm{H}-3,110$ & 121.30 & 81.8 & 4.6 & 13.6 & 1.00 \\
\hline $108-662 \mathrm{~A}-14 \mathrm{H}-3,119$ & 121.39 & 84.9 & 4.8 & 10.3 & 0.94 \\
\hline $108-662 \mathrm{~A}-14 \mathrm{H}-3,131$ & 121.51 & 85.1 & 4.9 & 9.9 & 0.94 \\
\hline $108-662 A-14 H-3,139$ & 121.59 & 82.7 & 5.7 & 11.6 & 0.94 \\
\hline $108-662 \mathrm{~A}-14 \mathrm{H}-3,146$ & 121.66 & 80.1 & 6.3 & 13.6 & 0.94 \\
\hline $108-662 \mathrm{~A}-14 \mathrm{H}-4,11$ & 121.81 & 76.9 & 8.0 & 15.1 & 0.88 \\
\hline $108-662 \mathrm{~A}-14 \mathrm{H}-4,19$ & 121.89 & 61.6 & 11.0 & 27.3 & 0.79 \\
\hline $108-662 A-14 H-4,29$ & 121.99 & 64.2 & 10.0 & 25.8 & 0.88 \\
\hline $108-662 \mathrm{~A}-14 \mathrm{H}-4,41$ & 122.11 & 81.7 & 5.7 & 12.7 & 0.92 \\
\hline $108-662 \mathrm{~A}-14 \mathrm{H}-4,50$ & 122.20 & 80.3 & 6.1 & 13.6 & 1.00 \\
\hline $108-662$ A- 14 H- 4,59 & 122.29 & 84.7 & 4.8 & 10.5 & 0.94 \\
\hline $108-662 \mathrm{~A}-14 \mathrm{H}-4,71$ & 122.41 & 85.0 & 4.1 & 10.9 & 1.00 \\
\hline $108-662 \mathrm{~A}-14 \mathrm{H}-4,79$ & 122.49 & 87.1 & 3.6 & 9.3 & 1.05 \\
\hline $108-662 \mathrm{~A}-14 \mathrm{H}-4,89$ & 122.59 & 88.2 & 2.8 & 9.1 & 1.03 \\
\hline $108-662 \mathrm{~A}-14 \mathrm{H}-4,101$ & 122.71 & 84.8 & 2.8 & 12.4 & 0.96 \\
\hline $108-662 \mathrm{~A}-14 \mathrm{H}-4,110$ & 122.80 & 86.7 & 3.8 & 9.5 & 1.02 \\
\hline $108-662 \mathrm{~A}-14 \mathrm{H}-4,119$ & 122.89 & 84.1 & 4.8 & 11.1 & 0.95 \\
\hline $108-662 \mathrm{~A}-14 \mathrm{H}-4,131$ & 123.01 & 82.1 & 5.7 & 12.1 & 0.90 \\
\hline $108-662 \mathrm{~A}-14 \mathrm{H}-4,139$ & 123.09 & 77.0 & 4.6 & 18.4 & 0.90 \\
\hline $108-662 \mathrm{~A}-14 \mathrm{H}-4,146$ & 123.16 & 81.6 & 3.1 & 15.3 & 1.03 \\
\hline $108-662 \mathrm{~A}-14 \mathrm{H}-5,11$ & 123.31 & 87.3 & 3.0 & 9.8 & 1.00 \\
\hline 108-662A-14H-5, 19 & 123.39 & 82.3 & 3.5 & 14.2 & 1.01 \\
\hline $108-662 A-14 H-5,29$ & 123.49 & 85.3 & 3.5 & 11.2 & 0.98 \\
\hline $108-662 A-14 H-5,41$ & 123.61 & 84.2 & 3.9 & 11.9 & 0.94 \\
\hline $108-662 A-14 H-5,50$ & 123.70 & 83.2 & 4.9 & 11.9 & 0.98 \\
\hline $108-662 A-14 H-5,59$ & 123.79 & 73.3 & 7.1 & 19.6 & 0.90 \\
\hline $108-662 A-14 H-5,71$ & 123.91 & 71.0 & 11.1 & 17.9 & 0.76 \\
\hline $108-662 \mathrm{~A}-14 \mathrm{H}-5,79$ & 123.99 & 68.5 & 7.5 & 24.0 & 0.84 \\
\hline $108-662 \mathrm{~A}-14 \mathrm{H}-5,89$ & 124.09 & 78.3 & 6.7 & 15.1 & 0.89 \\
\hline $108-662 \mathrm{~A}-14 \mathrm{H}-5,101$ & 124.21 & 79.8 & 6.2 & 14.0 & 0.89 \\
\hline $108-662 \mathrm{~A}-14 \mathrm{H}-5,110$ & 124.30 & 84.9 & 4.8 & 10.4 & 0.99 \\
\hline $108-662 \mathrm{~A}-14 \mathrm{H}-5,119$ & 124.39 & 82.9 & 4.6 & 12.5 & 0.97 \\
\hline $108-662 \mathrm{~A}-14 \mathrm{H}-5,131$ & 124.51 & 85.6 & 3.3 & 11.0 & 0.95 \\
\hline $108-662 \mathrm{~A}-14 \mathrm{H}-5,139$ & 124.59 & 90.9 & 2.9 & 6.2 & 0.96 \\
\hline $108-662 \mathrm{~A}-14 \mathrm{H}-5,146$ & 124.66 & 89.1 & 2.8 & 8.1 & 1.00 \\
\hline $108-662$ A- 14 H- 6,11 & 124.81 & 88.3 & 3.0 & 8.6 & 1.00 \\
\hline $108-662 A-14 H-6,19$ & 124.89 & 87.8 & 3.0 & 9.1 & 0.92 \\
\hline $108-662 A-14 H-6,29$ & 124.99 & 87.7 & 2.8 & 9.5 & 0.98 \\
\hline $108-662 A-14 H-6,41$ & 125.11 & 86.8 & 2.9 & 10.3 & 0.94 \\
\hline $108-662 A-14 H-6,50$ & 125.20 & 86.0 & 3.4 & 10.6 & 1.09 \\
\hline $108-662 \mathrm{~A}-14 \mathrm{H}-6,59$ & 125.29 & 81.8 & 4.9 & 13.3 & 0.93 \\
\hline $108-662 \mathrm{~A}-14 \mathrm{H}-6,71$ & 125.41 & 84.6 & 3.6 & 11.8 & 0.93 \\
\hline $108-662$ A- 14 H- 6,79 & 125.49 & 82.6 & 4.6 & 12.8 & 0.92 \\
\hline $108-662 A-14 H-6,89$ & 125.59 & 86.4 & 4.5 & 9.1 & 1.00 \\
\hline $108-662 \mathrm{~A}-14 \mathrm{H}-6,101$ & 125.71 & 84.8 & 4.0 & 11.2 & 0.98 \\
\hline $108-662 A-14 H-6,110$ & 125.80 & 74.8 & 5.9 & 19.3 & 0.95 \\
\hline 108-662A-14H-6, 119 & 125.89 & 87.1 & 3.3 & 9.6 & 1.03 \\
\hline $108-662 \mathrm{~A}-14 \mathrm{H}-6,131$ & 126.01 & 88.2 & 3.4 & 8.4 & 1.02 \\
\hline $108-662 A-14 H-6,139$ & 126.09 & 85.5 & 3.7 & 10.8 & 1.00 \\
\hline $108-662 A-14 H-6,146$ & 126.16 & 75.4 & 5.0 & 19.6 & 0.96 \\
\hline $108-662 \mathrm{~A}-14 \mathrm{H}-7,11$ & 126.31 & 86.6 & 2.9 & 10.5 & 1.01 \\
\hline $108-662 \mathrm{~A}-14 \mathrm{H}-7,14$ & 126.34 & 89.2 & 2.7 & 8.1 & 1.01 \\
\hline $108-662 \mathrm{~A}-15 \mathrm{H}-1,11$ & 126.81 & 86.6 & 4.5 & 8.8 & 0.87 \\
\hline $108-662 \mathrm{~A}-15 \mathrm{H}-1,19$ & 126.89 & 82.3 & 3.7 & 14.0 & 0.90 \\
\hline $108-662 \mathrm{~A}-15 \mathrm{H}-1,29$ & 126.99 & 84.7 & 4.3 & 11.0 & 0.92 \\
\hline $108-662 \mathrm{~A}-15 \mathrm{H}-1,41$ & 127.11 & 85.4 & 4.2 & 10.4 & 0.92 \\
\hline $108-662 \mathrm{~A}-15 \mathrm{H}-1,50$ & 127.20 & 83.8 & 5.5 & 10.8 & 0.97 \\
\hline $108-662 \mathrm{~A}-15 \mathrm{H}-1,59$ & 127.29 & 87.6 & 3.3 & 9.1 & 0.93 \\
\hline $108-662 \mathrm{~A}-15 \mathrm{H}-1,71$ & 127.41 & 87.5 & 3.1 & 9.4 & 0.92 \\
\hline 108-662A-15H-1, 79 & 127.49 & 86.8 & 3.7 & 9.5 & 0.94 \\
\hline $108-662 \mathrm{~A}-15 \mathrm{H}-1,89$ & 127.59 & 81.4 & 2.8 & 15.7 & 1.03 \\
\hline $108-662 \mathrm{~A}-15 \mathrm{H}-1,101$ & 127.71 & 88.1 & 3.0 & 9.0 & 0.96 \\
\hline $108-662 \mathrm{~A}-15 \mathrm{H}-1,110$ & 127.80 & 85.3 & 3.8 & 10.9 & 1.05 \\
\hline $108-662 \mathrm{~A}-15 \mathrm{H}-1,119$ & 127.89 & 87.1 & 3.4 & 9.6 & 1.00 \\
\hline $108-662 \mathrm{~A}-15 \mathrm{H}-1,131$ & 128.01 & 88.5 & 3.5 & 8.0 & 0.96 \\
\hline $108-662 \mathrm{~A}-15 \mathrm{H}-1,139$ & 128.09 & 87.9 & 3.1 & 9.0 & 0.94 \\
\hline 108-662A-15H-1, 146 & 128.16 & 79.9 & 4.8 & 15.3 & 0.95 \\
\hline $108-662 A-15 H-2,11$ & 128.31 & 79.2 & 4.6 & 16.1 & 0.96 \\
\hline
\end{tabular}

Table 4 (continued).

\begin{tabular}{|c|c|c|c|c|c|}
\hline $\begin{array}{l}\text { Core, section, } \\
\text { interval }(\mathrm{cm})\end{array}$ & $\begin{array}{l}\text { Depth } \\
\text { (mbsf) }\end{array}$ & $\begin{array}{c}\mathrm{CaCO}_{3} \\
(\%)\end{array}$ & $\begin{array}{l}\mathrm{SiO}_{2} \\
(\%)\end{array}$ & $\begin{array}{l}\text { Terrigenous } \\
\text { fraction } \\
(\%)\end{array}$ & $\begin{array}{c}\text { Dry-bulk } \\
\text { density } \\
\left(\mathrm{g} / \mathrm{cm}^{3}\right)\end{array}$ \\
\hline $108-662 \mathrm{~A}-15 \mathrm{H}-2,19$ & 128.39 & 80.5 & 5.4 & 14.1 & 0.93 \\
\hline $108-662 \mathrm{~A}-15 \mathrm{H}-2,29$ & 128.49 & 87.2 & 3.3 & 9.6 & 1.01 \\
\hline $108-662 \mathrm{~A}-15 \mathrm{H}-2,41$ & 128.61 & 89.0 & 2.4 & 8.7 & 1.02 \\
\hline $108-662 \mathrm{~A}-15 \mathrm{H}-2,50$ & 128.70 & 86.5 & 2.9 & 10.6 & 1.08 \\
\hline $108-662 \mathrm{~A}-15 \mathrm{H}-2,59$ & 128.79 & 87.6 & 2.2 & 10.2 & 1.00 \\
\hline $108-662 \mathrm{~A}-15 \mathrm{H}-2,71$ & 128.91 & 75.7 & 4.6 & 19.8 & 0.94 \\
\hline $108-662 \mathrm{~A}-15 \mathrm{H}-2,79$ & 128.99 & 81.7 & 4.3 & 14.0 & 0.93 \\
\hline $108-662 \mathrm{~A}-15 \mathrm{H}-2,89$ & 129.09 & 72.8 & 5.3 & 21.9 & 0.95 \\
\hline $108-662 \mathrm{~A}-15 \mathrm{H}-2,101$ & 129.21 & 65.1 & 7.0 & 27.9 & 0.92 \\
\hline $108-662 \mathrm{~A}-15 \mathrm{H}-2,110$ & 129.30 & 78.3 & 6.7 & 15.0 & 0.98 \\
\hline 108-662A-15H-2, 119 & 129.39 & 83.4 & 5.4 & 11.2 & 0.99 \\
\hline $108-662 \mathrm{~A}-15 \mathrm{H}-2,131$ & 129.51 & 88.3 & 3.5 & 8.2 & 1.02 \\
\hline $108-662 \mathrm{~A}-15 \mathrm{H}-2,139$ & 129.59 & 85.7 & 3.2 & 11.1 & 1.00 \\
\hline $108-662 \mathrm{~A}-15 \mathrm{H}-2,146$ & 129.66 & 79.9 & 2.8 & 17.3 & 1.02 \\
\hline $108-662 \mathrm{~A}-15 \mathrm{H}-3,11$ & 129.81 & 83.2 & 4.3 & 12.5 & 0.96 \\
\hline $108-662 \mathrm{~A}-15 \mathrm{H}-3,19$ & 129.89 & 84.1 & 4.3 & 11.6 & 0.95 \\
\hline $108-662 \mathrm{~A}-15 \mathrm{H}-3,29$ & 129.99 & 85.8 & 4.4 & 9.8 & 1.00 \\
\hline $108-662 \mathrm{~A}-15 \mathrm{H}-3,41$ & 130.11 & 73.8 & 5.9 & 20.3 & 0.91 \\
\hline $108-662 \mathrm{~A}-15 \mathrm{H}-3,50$ & 130.20 & 82.0 & 4.5 & 13.6 & 1.02 \\
\hline $108-662 \mathrm{~A}-15 \mathrm{H}-3,59$ & 130.29 & 82.2 & 4.5 & 13.3 & 1.00 \\
\hline $108-662 \mathrm{~A}-15 \mathrm{H}-3,71$ & 130.41 & 81.1 & 4.5 & 14.4 & 0.97 \\
\hline $108-662 \mathrm{~A}-15 \mathrm{H}-3,79$ & 130.49 & 84.1 & 4.6 & 11.3 & 0.96 \\
\hline $108-662 \mathrm{~A}-15 \mathrm{H}-3,89$ & 130.59 & 92.1 & 2.5 & 5.4 & 1.04 \\
\hline 108-662A-15H-3, 101 & 130.71 & 92.7 & 2.3 & 5.1 & 1.01 \\
\hline $108-662 \mathrm{~A}-15 \mathrm{H}-3,110$ & 130.80 & 91.1 & 1.9 & 7.1 & 1.08 \\
\hline $108-662 \mathrm{~A}-15 \mathrm{H}-3,119$ & 130.89 & 92.4 & 2.0 & 5.6 & 1.03 \\
\hline $108-662 \mathrm{~A}-15 \mathrm{H}-3,131$ & 131.01 & 91.0 & 2.7 & 6.3 & 1.01 \\
\hline $108-662 \mathrm{~A}-15 \mathrm{H}-3,139$ & 131.09 & 90.2 & 2.5 & 7.3 & 1.00 \\
\hline $108-662 \mathrm{~A}-15 \mathrm{H}-3,146$ & 131.16 & 88.2 & 2.7 & 9.1 & 1.03 \\
\hline $108-662 \mathrm{~A}-15 \mathrm{H}-4,11$ & 131.31 & 81.8 & 3.5 & 14.6 & 0.98 \\
\hline $108-662 \mathrm{~A}-15 \mathrm{H}-4,19$ & 131.39 & 89.0 & 2.2 & 8.8 & 1.06 \\
\hline $108-662 \mathrm{~A}-15 \mathrm{H}-4,29$ & 131.49 & 84.6 & 3.5 & 11.8 & 1.05 \\
\hline $108-662 \mathrm{~A}-15 \mathrm{H}-4,41$ & 131.61 & 86.9 & 2.0 & 11.2 & 1.05 \\
\hline $108-662 \mathrm{~A}-15 \mathrm{H}-4,50$ & 131.70 & 90.3 & 2.5 & 7.2 & 1.12 \\
\hline $108-662 \mathrm{~A}-15 \mathrm{H}-4,59$ & 131.79 & 87.5 & 2.9 & 9.6 & 1.09 \\
\hline $108-662 \mathrm{~A}-15 \mathrm{H}-4,71$ & 131.91 & 89.8 & 2.9 & 7.3 & 1.05 \\
\hline $108-662 \mathrm{~A}-15 \mathrm{H}-4,79$ & 131.99 & 87.4 & 3.6 & 9.0 & 1.02 \\
\hline $108-662 \mathrm{~A}-15 \mathrm{H}-4,89$ & 132.09 & 87.8 & 2.9 & 9.2 & 1.12 \\
\hline $108-662 \mathrm{~A}-15 \mathrm{H}-4,101$ & 132.21 & 86.1 & 3.2 & 10.8 & 1.04 \\
\hline $108-662 \mathrm{~A}-15 \mathrm{H}-4,110$ & 132.30 & 83.2 & 4.3 & 12.5 & 1.06 \\
\hline $108-662 \mathrm{~A}-15 \mathrm{H}-4,119$ & 132.39 & 81.7 & 5.6 & 12.7 & 1.03 \\
\hline $108-662 \mathrm{~A}-15 \mathrm{H}-4,131$ & 132.51 & 75.6 & 6.3 & 18.1 & 0.93 \\
\hline $108-662 \mathrm{~A}-15 \mathrm{H}-4,139$ & 132.59 & 84.7 & 5.2 & 10.1 & 1.00 \\
\hline $108-662 \mathrm{~A}-15 \mathrm{H}-4,146$ & 132.66 & 86.5 & 4.4 & 9.1 & 1.05 \\
\hline $108-662 \mathrm{~A}-15 \mathrm{H}-5,11$ & 132.81 & 86.2 & 5.3 & 8.5 & 0.97 \\
\hline $108-662 \mathrm{~A}-15 \mathrm{H}-5,19$ & 132.89 & 84.1 & 4.8 & 11.2 & 1.00 \\
\hline $108-662 \mathrm{~A}-15 \mathrm{H}-5,29$ & 132.99 & 84.2 & 4.8 & 11.1 & 1.07 \\
\hline $108-662 \mathrm{~A}-15 \mathrm{H}-5,41$ & 133.11 & 88.2 & 3.0 & 8.8 & 1.08 \\
\hline $108-662 \mathrm{~A}-15 \mathrm{H}-5,50$ & 133.20 & 88.8 & 2.2 & 9.0 & 1.11 \\
\hline $108-662 \mathrm{~A}-15 \mathrm{H}-5,59$ & 133.29 & 91.1 & 1.4 & 7.5 & 1.11 \\
\hline $108-662 \mathrm{~A}-15 \mathrm{H}-5,71$ & 133.41 & 91.6 & 1.7 & 6.7 & 1.03 \\
\hline $108-662 \mathrm{~A}-15 \mathrm{H}-5,79$ & 133.49 & 91.7 & 1.7 & 6.6 & 1.08 \\
\hline $108-662 \mathrm{~A}-15 \mathrm{H}-5,89$ & 133.59 & 91.5 & 1.5 & 7.1 & 1.16 \\
\hline $108-662 \mathrm{~A}-15 \mathrm{H}-5,101$ & 133.71 & 91.1 & 1.6 & 7.4 & 1.12 \\
\hline $108-662 \mathrm{~A}-15 \mathrm{H}-5,110$ & 133.80 & 87.3 & 2.4 & 10.3 & 1.10 \\
\hline $108-662 \mathrm{~A}-15 \mathrm{H}-5,119$ & 133.89 & 87.1 & 3.2 & 9.7 & 1.03 \\
\hline $108-662 \mathrm{~A}-15 \mathrm{H}-5,131$ & 134.01 & 77.1 & 5.8 & 17.2 & 0.95 \\
\hline $108-662 \mathrm{~A}-15 \mathrm{H}-5,139$ & 134.09 & 76.6 & 6.2 & 17.2 & 0.94 \\
\hline $108-662 \mathrm{~A}-15 \mathrm{H}-5,146$ & 134.16 & 73.1 & 7.7 & 19.2 & 0.93 \\
\hline $108-662 \mathrm{~A}-15 \mathrm{H}-6,11$ & 134.31 & 76.0 & 5.5 & 18.5 & 0.96 \\
\hline $108-662 \mathrm{~A}-15 \mathrm{H}-6,19$ & 134.89 & 80.0 & 5.4 & 14.7 & 0.96 \\
\hline $108-662 \mathrm{~A}-15 \mathrm{H}-6,29$ & 134.49 & 80.2 & 6.9 & 12.8 & 0.99 \\
\hline $108-662 \mathrm{~A}-15 \mathrm{H}-6,41$ & 134.61 & 81.4 & 7.1 & 11.5 & 0.95 \\
\hline $108-662 \mathrm{~A}-15 \mathrm{H}-6,50$ & 134.70 & 82.2 & 6.5 & 11.3 & 1.04 \\
\hline $108-662 \mathrm{~A}-15 \mathrm{H}-6,59$ & 134.79 & 87.3 & 3.4 & 9.3 & 1.13 \\
\hline $108-662 \mathrm{~A}-15 \mathrm{H}-6,71$ & 134.91 & 87.2 & 3.2 & 9.6 & 1.06 \\
\hline $108-662 \mathrm{~A}-15 \mathrm{H}-6,79$ & 134.99 & 88.5 & 2.9 & 8.6 & 1.00 \\
\hline $108-662 \mathrm{~A}-15 \mathrm{H}-6,89$ & 135.09 & 88.3 & 3.4 & 8.3 & 1.06 \\
\hline $108-662 \mathrm{~A}-15 \mathrm{H}-6,101$ & 135.21 & 82.2 & 4.6 & 13.2 & 1.03 \\
\hline $108-662 \mathrm{~A}-15 \mathrm{H}-6,110$ & 135.30 & 82.9 & 5.1 & 12.0 & 1.06 \\
\hline 108-662A-15H-6, 119 & 135.39 & 82.8 & 5.2 & 11.9 & 1.02 \\
\hline $108-662 \mathrm{~A}-15 \mathrm{H}-6,131$ & 135.51 & 79.8 & 4.9 & 15.3 & 1.01 \\
\hline $108-662 \mathrm{~A}-15 \mathrm{H}-6,139$ & 135.59 & 75.8 & 4.9 & 19.3 & 0.98 \\
\hline $108-662 \mathrm{~A}-15 \mathrm{H}-6,146$ & 135.66 & 75.5 & 6.0 & 18.5 & 1.01 \\
\hline $108-662 \mathrm{~A}-15 \mathrm{H}-7,11$ & 135.81 & 74.4 & 5.4 & 20.2 & 1.00 \\
\hline
\end{tabular}


Table 4 (continued).

\begin{tabular}{|c|c|c|c|c|c|}
\hline $\begin{array}{l}\text { Core, section, } \\
\text { interval }(\mathrm{cm})\end{array}$ & $\begin{array}{l}\text { Depth } \\
\text { (mbsf) }\end{array}$ & $\begin{array}{c}\mathrm{CaCO}_{3} \\
(\%)\end{array}$ & $\begin{array}{l}\mathrm{SiO}_{2} \\
(\%)\end{array}$ & $\begin{array}{c}\text { Terrigenous } \\
\text { fraction } \\
(\%)\end{array}$ & $\begin{array}{c}\text { Dry-bulk } \\
\text { density } \\
\left(\mathrm{g} / \mathrm{cm}^{3}\right)\end{array}$ \\
\hline $108-662 \mathrm{~A}-15 \mathrm{H}-7,19$ & 135.89 & 89.2 & 3.1 & 7.7 & 1.09 \\
\hline $108-662 A-15 H-7,29$ & 135.99 & 88.8 & 2.3 & 8.9 & 1.11 \\
\hline $108-662 \mathrm{~A}-15 \mathrm{H}-7,41$ & 136.11 & 88.7 & 2.6 & 8.7 & 1.04 \\
\hline $108-662 \mathrm{~A}-16 \mathrm{H}-1,3$ & 136.23 & 76.7 & 5.0 & 18.3 & 0.94 \\
\hline $108-662 \mathrm{~A}-16 \mathrm{H}-1,29$ & 136.49 & 79.7 & 4.5 & 15.8 & 1.03 \\
\hline $108-662 A-16 \mathrm{H}-1,31$ & 136.51 & 79.2 & 4.8 & 16.0 & 0.94 \\
\hline $108-662 \mathrm{~A}-16 \mathrm{H}-1,41$ & 136.61 & 72.5 & 5.8 & 21.7 & 0.93 \\
\hline $108-662 \mathrm{~A}-16 \mathrm{H}-1,50$ & 136.70 & 78.7 & 5.0 & 16.2 & 1.03 \\
\hline $108-662 \mathrm{~A}-16 \mathrm{H}-1,59$ & 136.79 & 84.0 & 4.9 & 11.1 & 1.00 \\
\hline $108-662 \mathrm{~A}-16 \mathrm{H}-1,71$ & 136.91 & 86.9 & 3.9 & 9.2 & 1.00 \\
\hline $108-662 \mathrm{~A}-16 \mathrm{H}-1,79$ & 136.99 & 89.1 & 3.0 & 8.0 & 1.05 \\
\hline $108-662 A-16 H-1,89$ & 137.09 & 88.4 & 2.8 & 8.8 & 1.09 \\
\hline $108-662 \mathrm{~A}-16 \mathrm{H}-1,101$ & 137.21 & 91.7 & 2.1 & 6.1 & 1.03 \\
\hline $108-662 \mathrm{~A}-16 \mathrm{H}-1,110$ & 137.30 & 90.5 & 2.6 & 6.9 & 1.03 \\
\hline $108-662 \mathrm{~A}-16 \mathrm{H}-1,119$ & 137.39 & 90.6 & 2.5 & 6.8 & 1.06 \\
\hline $108-662 \mathrm{~A}-16 \mathrm{H}-1,131$ & 137.51 & 87.8 & 2.5 & 9.7 & 1.02 \\
\hline $108-662 \mathrm{~A}-16 \mathrm{H}-1,139$ & 137.59 & 88.5 & 3.0 & 8.5 & 0.97 \\
\hline $108-662 \mathrm{~A}-16 \mathrm{H}-1,145$ & 137.65 & 88.0 & 3.0 & 9.0 & 1.00 \\
\hline $108-662 \mathrm{~A}-16 \mathrm{H}-2,11$ & 137.81 & 88.6 & 3.2 & 8.1 & 1.01 \\
\hline $108-662 A-16 H-2,19$ & 137.89 & 88.3 & 3.0 & 8.7 & 0.95 \\
\hline $108-662 \mathrm{~A}-16 \mathrm{H}-2,29$ & 137.99 & 85.7 & 7.5 & 6.8 & 1.02 \\
\hline $108-662 \mathrm{~A}-16 \mathrm{H}-2,41$ & 138.11 & 85.5 & 3.7 & 10.8 & 0.98 \\
\hline $108-662 \mathrm{~A}-16 \mathrm{H}-2,50$ & 138.20 & 88.8 & 3.3 & 7.9 & 1.02 \\
\hline $108-662 \mathrm{~A}-16 \mathrm{H}-2,59$ & 138.29 & 85.5 & 3.9 & 10.6 & 0.99 \\
\hline $108-662 \mathrm{~A}-16 \mathrm{H}-2,71$ & 138.41 & 81.2 & 5.5 & 13.3 & 0.98 \\
\hline $108-662 \mathrm{~A}-16 \mathrm{H}-2,79$ & 138.49 & 80.9 & 5.4 & 13.7 & 0.95 \\
\hline $108-662 \mathrm{~A}-16 \mathrm{H}-2,89$ & 138.59 & 66.0 & 7.7 & 26.3 & 0.87 \\
\hline $108-662 \mathrm{~A}-16 \mathrm{H}-2,101$ & 138.71 & 81.9 & 5.0 & 13.1 & 0.98 \\
\hline $108-662 \mathrm{~A}-16 \mathrm{H}-2,110$ & 138.80 & 81.2 & 5.3 & 13.5 & 0.95 \\
\hline $108-662 \mathrm{~A}-16 \mathrm{H}-2,119$ & 138.89 & 81.8 & 5.0 & 13.3 & 0.99 \\
\hline $108-662 \mathrm{~A}-16 \mathrm{H}-2,131$ & 139.01 & 82.9 & 5.5 & 11.6 & 0.95 \\
\hline $108-662 \mathrm{~A}-16 \mathrm{H}-2,139$ & 139.09 & 82.3 & 5.2 & 12.6 & 0.94 \\
\hline $108-662 \mathrm{~A}-16 \mathrm{H}-2,146$ & 139.16 & 84.9 & 3.4 & 11.7 & 1.07 \\
\hline $108-662 \mathrm{~A}-16 \mathrm{H}-3,11$ & 139.31 & 89.7 & 2.5 & 7.9 & 1.04 \\
\hline $108-662 \mathrm{~A}-16 \mathrm{H}-3,19$ & 139.39 & 90.3 & 2.5 & 7.2 & 1.00 \\
\hline $108-662 A-16 H-3,29$ & 139.49 & 89.5 & 2.6 & 7.9 & 0.99 \\
\hline $108-662 A-16 H-3,41$ & 139.61 & 90.5 & 2.5 & 7.0 & 1.05 \\
\hline $108-662 A-16 H-3,50$ & 139.70 & 90.4 & 2.4 & 7.2 & 1.06 \\
\hline $108-662 A-16 \mathrm{H}-3,59$ & 139.79 & 89.9 & 2.6 & 7.5 & 1.11 \\
\hline $108-662 A-16 H-3,71$ & 139.91 & 86.7 & 3.3 & 9.9 & 1.04 \\
\hline $108-662 \mathrm{~A}-16 \mathrm{H}-3,79$ & 139.99 & 77.5 & 3.9 & 18.6 & 1.02 \\
\hline $108-662 A-16 H-3,89$ & 140.09 & 84.8 & 4.0 & 11.2 & 1.02 \\
\hline $108-662 \mathrm{~A}-16 \mathrm{H}-3,101$ & 140.21 & 86.4 & 3.8 & 9.8 & 1.05 \\
\hline $108-662 \mathrm{~A}-16 \mathrm{H}-3,110$ & 140.30 & 88.4 & 3.1 & 8.4 & 1.02 \\
\hline 108-662A-16H-3, 119 & 140.39 & 88.3 & 2.8 & 9.0 & 1.10 \\
\hline $108-662 \mathrm{~A}-16 \mathrm{H}-3,131$ & 140.51 & 85.8 & 2.4 & 11.8 & 1.09 \\
\hline $108-662 \mathrm{~A}-16 \mathrm{H}-3,139$ & 140.59 & 89.0 & 2.8 & 8.1 & 1.07 \\
\hline $108-662 \mathrm{~A}-16 \mathrm{H}-3,146$ & 140.66 & 88.4 & 3.0 & 8.6 & 1.10 \\
\hline $108-662 \mathrm{~A}-16 \mathrm{H}-4,11$ & 140.81 & 86.1 & 3.4 & 10.5 & 1.04 \\
\hline $108-662 \mathrm{~A}-16 \mathrm{H}-4,19$ & 140.89 & 80.5 & 5.4 & 14.1 & 1.01 \\
\hline $108-662 \mathrm{~A}-16 \mathrm{H}-4,29$ & 140.99 & 78.6 & 6.5 & 14.9 & 1.00 \\
\hline $108-662 \mathrm{~A}-16 \mathrm{H}-4,41$ & 141.11 & 77.6 & 7.0 & 15.4 & 0.97 \\
\hline $108-662 \mathrm{~A}-16 \mathrm{H}-4,50$ & 141.20 & 82.2 & 5.1 & 12.7 & 1.02 \\
\hline $108-662 \mathrm{~A}-16 \mathrm{H}-4,59$ & 141.29 & 81.7 & 5.9 & 12.4 & 1.14 \\
\hline $108-662 \mathrm{~A}-16 \mathrm{H}-4,71$ & 141.41 & 79.3 & 5.9 & 14.8 & 0.99 \\
\hline $108-662 \mathrm{~A}-16 \mathrm{H}-4,79$ & 141.49 & 80.5 & 5.6 & 13.8 & 1.00 \\
\hline $108-662 \mathrm{~A}-16 \mathrm{H}-4,89$ & 141.59 & 80.3 & 4.6 & 15.2 & 1.09 \\
\hline $108-662 \mathrm{~A}-16 \mathrm{H}-4,101$ & 141.71 & 89.4 & 2.5 & 8.2 & 1.08 \\
\hline $108-662 \mathrm{~A}-16 \mathrm{H}-4,110$ & 141.80 & 91.9 & 2.3 & 5.8 & 1.04 \\
\hline $108-662 \mathrm{~A}-16 \mathrm{H}-4,119$ & 141.89 & 90.4 & 2.1 & 7.4 & 1.13 \\
\hline $108-662 \mathrm{~A}-16 \mathrm{H}-4,131$ & 142.01 & 89.2 & 1.9 & 8.9 & 1.05 \\
\hline $108-662 \mathrm{~A}-16 \mathrm{H}-4,139$ & 142.09 & 92.2 & 2.3 & 5.5 & 1.06 \\
\hline $108-662 \mathrm{~A}-16 \mathrm{H}-4,146$ & 142.16 & 90.7 & 2.1 & 7.1 & 1.05 \\
\hline $108-662 \mathrm{~A}-16 \mathrm{H}-5,11$ & 142.31 & 87.4 & 2.9 & 9.6 & 1.05 \\
\hline $108-662 A-16 H-5,19$ & 142.39 & 76.4 & 5.0 & 18.7 & 0.99 \\
\hline $108-662 \mathrm{~A}-16 \mathrm{H}-5,29$ & 142.49 & 87.0 & 3.5 & 9.4 & 1.04 \\
\hline $108-662 \mathrm{~A}-16 \mathrm{H}-5,41$ & 142.61 & 89.3 & 3.3 & 7.4 & 0.99 \\
\hline $108-662 A-16 H-5,50$ & 142.70 & 87.9 & 3.7 & 8.4 & 0.98 \\
\hline $108-662 \mathrm{~A}-16 \mathrm{H}-5,59$ & 142.79 & 89.4 & 3.0 & 7.6 & 1.05 \\
\hline $108-662 A-16 H-5,71$ & 142.91 & 88.8 & 4.8 & 6.5 & 1.05 \\
\hline $108-662 \mathrm{~A}-16 \mathrm{H}-5,79$ & 142.99 & 87.6 & 3.6 & 8.8 & 1.01 \\
\hline $108-662 A-16 H-5,89$ & 143.09 & 88.5 & 3.2 & 8.3 & 1.04 \\
\hline $108-662 \mathrm{~A}-16 \mathrm{H}-5,101$ & 143.21 & 85.6 & 3.7 & 10.7 & 1.02 \\
\hline $108-662 \mathrm{~A}-16 \mathrm{H}-5,110$ & 143.30 & 86.7 & 3.3 & 10.0 & 1.02 \\
\hline $108-662 \mathrm{~A}-16 \mathrm{H}-5,119$ & 143.39 & 83.9 & 4.1 & 12.1 & 1.02 \\
\hline $108-662 A-16 \mathrm{H}-5,131$ & 143.51 & 91.4 & 2.4 & 6.2 & 1.08 \\
\hline
\end{tabular}

Table 4 (continued).

\begin{tabular}{|c|c|c|c|c|c|}
\hline $\begin{array}{l}\text { Core, section, } \\
\text { interval }(\mathrm{cm})\end{array}$ & $\begin{array}{l}\text { Depth } \\
\text { (mbsf) }\end{array}$ & $\begin{array}{c}\mathrm{CaCO}_{3} \\
(\%)\end{array}$ & $\begin{array}{c}\mathrm{SiO}_{2} \\
(\%)\end{array}$ & $\begin{array}{l}\text { Terrigenous } \\
\text { fraction } \\
(\%)\end{array}$ & $\begin{array}{c}\text { Dry-bulk } \\
\text { density } \\
\left(\mathrm{g} / \mathrm{cm}^{3}\right)\end{array}$ \\
\hline $108-662 \mathrm{~A}-16 \mathrm{H}-5,139$ & 143.59 & 85.7 & 2.3 & 12.0 & 1.02 \\
\hline $108-662 \mathrm{~A}-16 \mathrm{H}-6,11$ & 143.81 & 90.3 & 2.2 & 7.4 & 1.03 \\
\hline $108-662 \mathrm{~A}-16 \mathrm{H}-6,19$ & 143.89 & 89.8 & 2.5 & 7.6 & 1.05 \\
\hline $108-662 \mathrm{~A}-16 \mathrm{H}-6,29$ & 143.99 & 91.0 & 2.5 & 6.5 & 1.13 \\
\hline $108-662 \mathrm{~A}-16 \mathrm{H}-6,41$ & 144.11 & 89.6 & 2.1 & 8.3 & 1.07 \\
\hline $108-662 \mathrm{~A}-16 \mathrm{H}-6,50$ & 144.20 & 93.9 & 2.2 & 3.8 & 1.08 \\
\hline $108-662 \mathrm{~A}-16 \mathrm{H}-6,59$ & 144.29 & 91.3 & 1.9 & 6.9 & 1.10 \\
\hline $108-662 \mathrm{~A}-16 \mathrm{H}-6,71$ & 144.41 & 92.0 & 1.9 & 6.1 & 1.05 \\
\hline $108-662 \mathrm{~A}-16 \mathrm{H}-6,79$ & 144.49 & 92.0 & 2.1 & 5.9 & 1.10 \\
\hline $108-662 \mathrm{~A}-16 \mathrm{H}-6,89$ & 144.59 & 88.2 & 2.2 & 9.6 & 1.09 \\
\hline $108-662 \mathrm{~A}-16 \mathrm{H}-6,101$ & 144.71 & 92.2 & 2.2 & 5.6 & 1.04 \\
\hline $108-662 \mathrm{~A}-16 \mathrm{H}-6,110$ & 144.80 & 92.7 & 2.5 & 4.8 & 1.07 \\
\hline $108-662 \mathrm{~A}-16 \mathrm{H}-6,119$ & 144.89 & 90.6 & 2.2 & 7.1 & 1.09 \\
\hline $108-662 \mathrm{~A}-16 \mathrm{H}-6,131$ & 145.01 & 91.0 & 2.3 & 6.7 & 1.07 \\
\hline $108-662 \mathrm{~A}-16 \mathrm{H}-6,139$ & 145.09 & 89.7 & 2.5 & 7.8 & 1.03 \\
\hline $108-662 \mathrm{~A}-16 \mathrm{H}-6,146$ & 145.16 & 90.4 & 2.1 & 7.4 & 1.05 \\
\hline $108-662 \mathrm{~A}-16 \mathrm{H}-7,11$ & 145.31 & 89.4 & 2.4 & 8.2 & 1.06 \\
\hline $108-662 \mathrm{~A}-16 \mathrm{H}-7,19$ & 145.39 & 91.9 & 2.0 & 6.1 & 1.02 \\
\hline $108-662 \mathrm{~A}-16 \mathrm{H}-7,29$ & 145.49 & 90.0 & 1.9 & 8.2 & 1.05 \\
\hline $108-662 \mathrm{~A}-16 \mathrm{H}-7,41$ & 145.61 & 91.3 & 2.3 & 6.5 & 1.06 \\
\hline $108-662 \mathrm{~A}-16 \mathrm{H}-7,51$ & 145.71 & 91.3 & 1.3 & 7.4 & 1.06 \\
\hline $108-662 \mathrm{~A}-17 \mathrm{H}-1,11$ & 145.81 & 77.5 & 5.0 & 17.5 & 0.96 \\
\hline $108-662 \mathrm{~A}-17 \mathrm{H}-1,19$ & 145.89 & 81.7 & 4.6 & 13.8 & 0.99 \\
\hline $108-662 \mathrm{~A}-17 \mathrm{H}-1,29$ & 145.99 & 89.8 & 1.9 & 8.3 & 1.06 \\
\hline $108-662 \mathrm{~A}-17 \mathrm{H}-1,41$ & 146.11 & 91.3 & 1.7 & 7.0 & 1.01 \\
\hline $108-662 \mathrm{~A}-17 \mathrm{H}-1,42$ & 146.12 & 91.8 & 2.7 & 5.6 & 1.01 \\
\hline $108-662 \mathrm{~A}-17 \mathrm{H}-1,50$ & 146.20 & 87.1 & 5.7 & 7.3 & 0.96 \\
\hline $108-662 \mathrm{~A}-17 \mathrm{H}-1,59$ & 146.29 & 85.0 & 6.3 & 8.8 & 0.96 \\
\hline $108-662 \mathrm{~A}-17 \mathrm{H}-1,71$ & 146.41 & 85.4 & 5.4 & 9.1 & 0.96 \\
\hline $108-662 \mathrm{~A}-17 \mathrm{H}-1,79$ & 146.49 & 81.5 & 9.5 & 9.0 & 0.90 \\
\hline $108-662 \mathrm{~A}-17 \mathrm{H}-1,89$ & 146.59 & 86.2 & 6.8 & 7.1 & 0.98 \\
\hline $108-662 \mathrm{~A}-17 \mathrm{H}-1,101$ & 146.71 & 87.1 & 2.9 & 10.0 & 1.01 \\
\hline $108-662 \mathrm{~A}-17 \mathrm{H}-1,110$ & 146.80 & 88.6 & 3.2 & 8.2 & 1.01 \\
\hline $108-662 \mathrm{~A}-17 \mathrm{H}-1,119$ & 146.89 & 90.2 & 2.5 & 7.3 & 1.07 \\
\hline $108-662 \mathrm{~A}-17 \mathrm{H}-1,130$ & 147.00 & 88.5 & 2.6 & 8.8 & 1.03 \\
\hline $108-662 \mathrm{~A}-17 \mathrm{H}-1,139$ & 147.09 & 85.7 & 3.5 & 10.8 & 0.97 \\
\hline $108-662 \mathrm{~A}-17 \mathrm{H}-1,142$ & 147.12 & 89.2 & 3.5 & 7.3 & 1.00 \\
\hline $108-662 \mathrm{~A}-17 \mathrm{H}-1,146$ & 147.16 & 81.8 & 2.6 & 15.6 & 1.10 \\
\hline $108-662 \mathrm{~A}-17 \mathrm{H}-2,9$ & 147.29 & 70.9 & 4.6 & 24.5 & 0.91 \\
\hline $108-662 \mathrm{~A}-17 \mathrm{H}-2,13$ & 147.33 & 65.2 & 8.3 & 26.5 & 0.87 \\
\hline $108-662 \mathrm{~A}-17 \mathrm{H}-2,19$ & 147.39 & 64.4 & 7.8 & 27.8 & 0.85 \\
\hline $108-662 \mathrm{~A}-17 \mathrm{H}-2,29$ & 147.49 & 85.4 & 3.7 & 10.9 & 1.05 \\
\hline $108-662 \mathrm{~A}-17 \mathrm{H}-2,38$ & 147.58 & 87.5 & 2.9 & 9.6 & 1.01 \\
\hline $108-662 \mathrm{~A}-17 \mathrm{H}-2,41$ & 147.61 & 87.8 & 3.7 & 8.4 & 0.98 \\
\hline $108-662 \mathrm{~A}-17 \mathrm{H}-2,50$ & 147.70 & 88.0 & 2.9 & 9.1 & 1.00 \\
\hline $108-662 \mathrm{~A}-17 \mathrm{H}-2,59$ & 147.79 & 90.7 & 2.5 & 6.8 & 1.09 \\
\hline $108-662 \mathrm{~A}-17 \mathrm{H}-2,71$ & 147.91 & 88.9 & 1.9 & 9.2 & 1.05 \\
\hline $108-662 \mathrm{~A}-17 \mathrm{H}-2,79$ & 147.99 & 88.8 & 1.9 & 9.3 & 1.00 \\
\hline $108-662 \mathrm{~A}-17 \mathrm{H}-2,89$ & 148.09 & 90.5 & 2.0 & 7.5 & 1.01 \\
\hline $108-662 \mathrm{~A}-17 \mathrm{H}-2,101$ & 148.21 & 90.8 & 2.1 & 7.1 & 1.01 \\
\hline $108-662 \mathrm{~A}-17 \mathrm{H}-2,110$ & 148.30 & 90.8 & 2.0 & 7.1 & 1.03 \\
\hline $108-662 \mathrm{~A}-17 \mathrm{H}-2,119$ & 148.39 & 90.2 & 1.8 & 8.0 & 1.02 \\
\hline $108-662 \mathrm{~A}-17 \mathrm{H}-2,130$ & 148.50 & 88.8 & 2.2 & 8.9 & 1.00 \\
\hline $108-662 \mathrm{~A}-17 \mathrm{H}-2,139$ & 148.59 & 88.1 & 2.5 & 9.3 & 1.01 \\
\hline $108-662 \mathrm{~A}-17 \mathrm{H}-2,142$ & 148.62 & 90.0 & 2.2 & 7.8 & 1.06 \\
\hline $108-662 \mathrm{~A}-17 \mathrm{H}-2,145$ & 148.65 & 89.2 & 2.1 & 8.7 & 1.08 \\
\hline $108-662 \mathrm{~A}-17 \mathrm{H}-3,12$ & 148.82 & 88.6 & 2.3 & 9.2 & 1.00 \\
\hline $108-662 \mathrm{~A}-17 \mathrm{H}-3,14$ & 148.84 & 90.5 & 2.3 & 7.2 & 1.08 \\
\hline $108-662 \mathrm{~A}-17 \mathrm{H}-3,17$ & 148.87 & 87.0 & 2.7 & 10.2 & 0.96 \\
\hline $108-662 \mathrm{~A}-17 \mathrm{H}-3,32$ & 149.02 & 73.8 & 6.8 & 19.4 & 0.90 \\
\hline $108-662 \mathrm{~A}-17 \mathrm{H}-3,41$ & 149.11 & 81.2 & 5.9 & 12.9 & 0.97 \\
\hline $108-662 \mathrm{~A}-17 \mathrm{H}-3,43$ & 149.13 & 85.0 & 3.2 & 11.8 & 1.04 \\
\hline $108-662 \mathrm{~A}-17 \mathrm{H}-3,50$ & 149.20 & 84.8 & 3.7 & 11.6 & 1.04 \\
\hline $108-662 \mathrm{~A}-17 \mathrm{H}-3,59$ & 149.29 & 63.5 & 6.8 & 29.7 & 1.08 \\
\hline $108-662 \mathrm{~A}-17 \mathrm{H}-3,71$ & 149.41 & 69.2 & 1.4 & 29.3 & 1.04 \\
\hline $108-662 \mathrm{~A}-17 \mathrm{H}-3,79$ & 149.49 & 78.8 & 4.0 & 17.2 & 0.98 \\
\hline $108-662 \mathrm{~A}-17 \mathrm{H}-3,89$ & 149.59 & 84.3 & 4.4 & 11.3 & 1.05 \\
\hline $108-662 \mathrm{~A}-17 \mathrm{H}-3,101$ & 149.71 & 76.0 & 3.2 & 20.7 & 1.02 \\
\hline $108-662 \mathrm{~A}-17 \mathrm{H}-3,118$ & 149.88 & 90.7 & 2.3 & 7.0 & 1.03 \\
\hline $108-662 \mathrm{~A}-17 \mathrm{H}-4,11$ & 150.31 & 91.8 & 2.7 & 5.5 & 1.01 \\
\hline $108-662 \mathrm{~A}-17 \mathrm{H}-4,14$ & 150.33 & 90.1 & 2.0 & 7.8 & 0.99 \\
\hline $108-662 \mathrm{~A}-17 \mathrm{H}-4,19$ & 150.39 & 90.8 & 2.5 & 6.7 & 0.73 \\
\hline $108-662 \mathrm{~A}-17 \mathrm{H}-4,29$ & 150.49 & 83.7 & 2.5 & 13.9 & 0.96 \\
\hline $108-662 \mathrm{~A}-17 \mathrm{H}-4,41$ & 150.61 & 60.7 & 6.8 & 32.5 & 0.89 \\
\hline $108-662 \mathrm{~A}-17 \mathrm{H}-4,43$ & 150.63 & 68.1 & 6.1 & 25.7 & 0.89 \\
\hline $108-662 \mathrm{~A}-17 \mathrm{H}-4,50$ & 150.70 & 87.9 & 2.5 & 9.6 & 1.00 \\
\hline
\end{tabular}


Table 4 (continued).

\begin{tabular}{|c|c|c|c|c|c|}
\hline $\begin{array}{l}\text { Core, section, } \\
\text { interval }(\mathrm{cm})\end{array}$ & $\begin{array}{l}\text { Depth } \\
\text { (mbsf) }\end{array}$ & $\begin{array}{c}\mathrm{CaCO}_{3} \\
(\%)\end{array}$ & $\begin{array}{c}\mathrm{SiO}_{2} \\
(\%)\end{array}$ & $\begin{array}{c}\text { Terrigenous } \\
\text { fraction } \\
(\%)\end{array}$ & $\begin{array}{c}\text { Dry-bulk } \\
\text { density } \\
\left(\mathrm{g} / \mathrm{cm}^{3}\right)\end{array}$ \\
\hline $108-662 A-17 \mathrm{H}-4,59$ & 150.79 & 62.0 & 3.8 & 34.3 & 1.02 \\
\hline $108-662$ A- 17 H- 4,71 & 150.91 & 82.7 & 3.7 & 13.7 & 0.99 \\
\hline $108-662 \mathrm{~A}-17 \mathrm{H}-4,79$ & 150.99 & 83.3 & 3.6 & 13.1 & 0.97 \\
\hline $108-662 \mathrm{~A}-17 \mathrm{H}-4,89$ & 151.09 & 88.1 & 3.5 & 8.4 & 1.01 \\
\hline $108-662 \mathrm{~A}-17 \mathrm{H}-4,110$ & 151.30 & 85.8 & 3.1 & 11.1 & 1.05 \\
\hline $108-662 \mathrm{~A}-17 \mathrm{H}-4,101$ & 151.21 & 85.3 & 4.6 & 10.1 & 1.01 \\
\hline $108-662 \mathrm{~A}-17 \mathrm{H}-4,119$ & 151.39 & 85.2 & 3.2 & 11.7 & 1.06 \\
\hline $108-662 \mathrm{~A}-17 \mathrm{H}-4,130$ & 151.50 & 81.3 & 3.3 & 15.4 & 1.06 \\
\hline $108-662 \mathrm{~A}-17 \mathrm{H}-4,139$ & 151.59 & 68.3 & 7.2 & 24.5 & 0.93 \\
\hline $108-662 \mathrm{~A}-17 \mathrm{H}-4,142$ & 151.62 & 72.5 & 5.9 & 21.6 & 0.99 \\
\hline $108-662 \mathrm{~A}-17 \mathrm{H}-4,146$ & 151.66 & 84.0 & 4.6 & 11.4 & 1.03 \\
\hline $108-662 \mathrm{~A}-17 \mathrm{H}-5,11$ & 151.81 & 89.4 & 3.4 & 7.2 & 1.09 \\
\hline $108-662 \mathrm{~A}-17 \mathrm{H}-5,14$ & 151.83 & 88.4 & 2.8 & 8.9 & 1.03 \\
\hline $108-662 \mathrm{~A}-17 \mathrm{H}-5,19$ & 151.89 & 87.5 & 2.9 & 9.6 & 1.02 \\
\hline $108-662 A-17 \mathrm{H}-5,29$ & 151.99 & 91.1 & 2.3 & 6.6 & 1.32 \\
\hline $108-662 \mathrm{~A}-17 \mathrm{H}-5,41$ & 152.11 & 89.5 & 2.8 & 7.7 & 1.04 \\
\hline $108-662 A-17 \mathrm{H}-5,50$ & 152.20 & 88.0 & 1.9 & 10.1 & 1.04 \\
\hline $108-662 A-17 \mathrm{H}-5,59$ & 152.29 & 89.2 & 2.2 & 8.6 & 1.05 \\
\hline $108-662 \mathrm{~A}-17 \mathrm{H}-5,71$ & 152.41 & 87.4 & 2.3 & 10.3 & 1.02 \\
\hline $108-662 A-17 \mathrm{H}-5,79$ & 152.49 & 90.2 & 2.3 & 7.5 & 0.99 \\
\hline $108-662 \mathrm{~A}-17 \mathrm{H}-5,89$ & 152.59 & 87.5 & 3.0 & 9.4 & 1.04 \\
\hline $108-662 \mathrm{~A}-17 \mathrm{H}-5,101$ & 152.71 & 87.6 & 2.7 & 9.8 & 1.03 \\
\hline $108-662 \mathrm{~A}-17 \mathrm{H}-5,110$ & 152.80 & 87.8 & 2.9 & 9.3 & 1.03 \\
\hline 108-662A-17H-5, 119 & 152.89 & 87.1 & 3.3 & 9.7 & 1.17 \\
\hline $108-662 \mathrm{~A}-17 \mathrm{H}-5,130$ & 153.00 & 88.5 & 3.1 & 8.4 & 1.12 \\
\hline 108-662A-17H-5, 139 & 153.09 & 87.8 & 3.0 & 9.2 & 0.99 \\
\hline $108-662 \mathrm{~A}-17 \mathrm{H}-5,142$ & 153.12 & 87.8 & 2.6 & 9.6 & 1.14 \\
\hline $108-662 A-17 H-5,146$ & 153.16 & 85.4 & 2.5 & 12.1 & 1.22 \\
\hline $108-662$ A-17H-6, 11 & 153.31 & 88.7 & 2.3 & 9.0 & 1.02 \\
\hline $108-662$ A-17H- 6,14 & 153.33 & 90.2 & 2.2 & 7.6 & 1.14 \\
\hline $108-662$ A- 17 H- 6,19 & 153.39 & 88.5 & 2.7 & 8.8 & 1.00 \\
\hline $108-662 \mathrm{~A}-17 \mathrm{H}-6,29$ & 153.49 & 87.8 & 3.0 & 9.2 & 1.04 \\
\hline $108-662$ A-17H- 6,41 & 153.61 & 84.3 & 4.1 & 11.6 & 1.02 \\
\hline $108-662 \mathrm{~A}-17 \mathrm{H}-6,50$ & 153.70 & 84.6 & 3.7 & 11.6 & 1.12 \\
\hline $108-662$ A-17H- 6,59 & 153.79 & 90.0 & 2.3 & 7.7 & 1.04 \\
\hline $108-662 A-17 \mathrm{H}-6,71$ & 153.91 & 92.9 & 2.1 & 5.0 & 1.04 \\
\hline $108-662$ A- 17 H- 6,79 & 153.99 & 92.4 & 1.9 & 5.8 & 1.00 \\
\hline $108-662 A-17 \mathrm{H}-6,89$ & 154.09 & 92.3 & 2.1 & 5.6 & 1.04 \\
\hline 108-662A-17H-6, 101 & 154.21 & 91.8 & 2.6 & 5.6 & 1.04 \\
\hline $108-662 \mathrm{~A}-17 \mathrm{H}-6,110$ & 154.30 & 86.4 & 3.0 & 10.6 & 1.12 \\
\hline 108-662A-17H-6, 119 & 154.39 & 78.4 & 5.4 & 16.2 & 0.99 \\
\hline 108-662A-17H-6, 124 & 154.44 & 72.9 & 5.1 & 22.0 & 1.04 \\
\hline 108-662A-17H-6, 129 & 154.49 & 78.6 & 3.8 & 17.6 & 0.99 \\
\hline $108-662 \mathrm{~A}-18 \mathrm{H}-1,11$ & 155.31 & 91.5 & 2.1 & 6.4 & 0.96 \\
\hline $108-662 \mathrm{~A}-18 \mathrm{H}-1,19$ & 155.39 & 92.7 & 1.8 & 5.5 & 0.98 \\
\hline $108-662 \mathrm{~A}-18 \mathrm{H}-1,29$ & 155.49 & 90.0 & 2.4 & 7.6 & 0.98 \\
\hline $108-662 \mathrm{~A}-18 \mathrm{H}-1,41$ & 155.61 & 90.0 & 2.7 & 7.3 & 1.04 \\
\hline $108-662 \mathrm{~A}-18 \mathrm{H}-1,50$ & 155.70 & 89.6 & 2.3 & 8.1 & 1.12 \\
\hline $108-662 \mathrm{~A}-18 \mathrm{H}-1,59$ & 155.79 & 89.6 & 2.5 & 7.9 & 0.73 \\
\hline $108-662 A-18 H-1,71$ & 155.91 & 89.8 & 2.5 & 7.7 & 0.98 \\
\hline $108-662 \mathrm{~A}-18 \mathrm{H}-1,79$ & 155.99 & 76.4 & 2.5 & 21.1 & 0.96 \\
\hline $108-662 A-18 H-1,89$ & 156.09 & 87.1 & 2.2 & 10.8 & 1.00 \\
\hline $108-662 \mathrm{~A}-18 \mathrm{H}-1,101$ & 156.21 & 90.7 & 2.2 & 7.2 & 0.98 \\
\hline $108-662 \mathrm{~A}-18 \mathrm{H}-1,110$ & 156.30 & 84.6 & 3.7 & 11.7 & 1.14 \\
\hline $108-662 \mathrm{~A}-18 \mathrm{H}-1,119$ & 156.39 & 88.5 & 4.1 & 7.4 & 0.93 \\
\hline $108-662 \mathrm{~A}-18 \mathrm{H}-1,131$ & 156.51 & 87.0 & 4.0 & 9.1 & 0.98 \\
\hline $108-662 \mathrm{~A}-18 \mathrm{H}-1,139$ & 156.59 & 83.4 & 4.4 & 12.3 & 0.95 \\
\hline $108-662 \mathrm{~A}-18 \mathrm{H}-1,147$ & 156.67 & 82.5 & 4.6 & 12.9 & 0.99 \\
\hline $108-662 \mathrm{~A}-18 \mathrm{H}-2,11$ & 156.81 & 85.2 & 4.0 & 10.8 & 1.01 \\
\hline $108-662 \mathrm{~A}-18 \mathrm{H}-2,19$ & 156.89 & 86.6 & 2.8 & 10.7 & 1.01 \\
\hline $108-662 \mathrm{~A}-18 \mathrm{H}-2,41$ & 157.11 & 93.6 & 1.8 & 4.6 & 1.00 \\
\hline $108-662 \mathrm{~A}-18 \mathrm{H}-2,50$ & 157.20 & 92.5 & 1.7 & 5.8 & 1.09 \\
\hline $108-662 \mathrm{~A}-18 \mathrm{H}-2,59$ & 157.29 & 93.2 & 1.6 & 5.2 & 1.02 \\
\hline $108-662 \mathrm{~A}-18 \mathrm{H}-2,71$ & 157.41 & 90.3 & 2.2 & 7.5 & 0.99 \\
\hline $108-662 \mathrm{~A}-18 \mathrm{H}-2,79$ & 157.49 & 87.4 & 2.6 & 10.0 & 0.92 \\
\hline $108-662 \mathrm{~A}-18 \mathrm{H}-2,89$ & 157.59 & 91.5 & 2.3 & 6.2 & 1.01 \\
\hline $108-662 \mathrm{~A}-18 \mathrm{H}-2,101$ & 157.71 & 87.3 & 2.5 & 10.1 & 1.04 \\
\hline $108-662 \mathrm{~A}-18 \mathrm{H}-2,110$ & 157.80 & 86.8 & 2.8 & 10.4 & 1.05 \\
\hline 108-662A-18H-2, 119 & 157.89 & 86.2 & 5.7 & 8.1 & 1.00 \\
\hline $108-662 \mathrm{~A}-18 \mathrm{H}-2,131$ & 158.01 & 85.5 & 3.9 & 10.6 & 1.02 \\
\hline 108-662A-18H-2, 139 & 158.09 & 89.1 & 2.8 & 8.1 & 1.02 \\
\hline 108-662A-18H-2, 144 & 158.14 & 89.2 & 2.6 & 8.2 & 1.09 \\
\hline $108-662 \mathrm{~A}-18 \mathrm{H}-3,11$ & 158.31 & 90.8 & 2.6 & 6.6 & 1.02 \\
\hline $108-662 A-18 H-3,19$ & 158.39 & 90.7 & 2.5 & 6.8 & 1.01 \\
\hline $108-662$ A- 18 H-3, 29 & 158.49 & 91.2 & 2.0 & 6.8 & 1.16 \\
\hline $108-662 \mathrm{~A}-18 \mathrm{H}-3,41$ & 158.61 & 90.9 & 1.8 & 7.4 & 1.06 \\
\hline
\end{tabular}

Table 4 (continued).

\begin{tabular}{|c|c|c|c|c|c|}
\hline $\begin{array}{l}\text { Core, section, } \\
\text { interval }(\mathrm{cm})\end{array}$ & $\begin{array}{l}\text { Depth } \\
\text { (mbsf) }\end{array}$ & $\begin{array}{c}\mathrm{CaCO}_{3} \\
(\%)\end{array}$ & $\begin{array}{c}\mathrm{SiO}_{2} \\
(\%)\end{array}$ & $\begin{array}{l}\text { Terrigenous } \\
\text { fraction } \\
(\%)\end{array}$ & $\begin{array}{c}\text { Dry-bulk } \\
\text { density } \\
\left(\mathrm{g} / \mathrm{cm}^{3}\right)\end{array}$ \\
\hline $108-662 \mathrm{~A}-18 \mathrm{H}-3,50$ & 158.70 & 93.7 & 1.5 & 4.9 & 1.08 \\
\hline $108-662 \mathrm{~A}-18 \mathrm{H}-3,59$ & 158.79 & 93.7 & 1.5 & 4.8 & 1.02 \\
\hline $108-662 \mathrm{~A}-18 \mathrm{H}-3,71$ & 158.91 & 94.5 & 1.6 & 4.0 & 1.05 \\
\hline $108-662 \mathrm{~A}-18 \mathrm{H}-3,79$ & 158.99 & 93.4 & 1.4 & 5.2 & 1.00 \\
\hline $108-662 \mathrm{~A}-18 \mathrm{H}-3,89$ & 159.09 & 90.9 & 1.6 & 7.4 & 1.00 \\
\hline $108-662 \mathrm{~A}-18 \mathrm{H}-3,101$ & 159.21 & 92.3 & 1.9 & 5.8 & 0.99 \\
\hline $108-662 \mathrm{~A}-18 \mathrm{H}-3,110$ & 159.30 & 92.7 & 1.8 & 5.5 & 1.03 \\
\hline $108-662 \mathrm{~A}-18 \mathrm{H}-3,119$ & 159.39 & 93.9 & 1.9 & 4.2 & 0.98 \\
\hline $108-662 \mathrm{~A}-18 \mathrm{H}-3,131$ & 159.51 & 94.7 & 1.5 & 3.8 & 0.97 \\
\hline $108-662 \mathrm{~A}-18 \mathrm{H}-3,139$ & 159.59 & 92.0 & 1.6 & 6.3 & 0.91 \\
\hline $108-662 \mathrm{~A}-18 \mathrm{H}-3,147$ & 159.67 & 94.0 & 1.6 & 4.5 & 0.97 \\
\hline $108-662 \mathrm{~A}-18 \mathrm{H}-4,11$ & 159.81 & 91.0 & 1.9 & 7.2 & 1.02 \\
\hline $108-662 \mathrm{~A}-18 \mathrm{H}-4,19$ & 159.89 & 86.9 & 1.6 & 11.5 & 0.98 \\
\hline $108-662 \mathrm{~A}-18 \mathrm{H}-4,29$ & 159.99 & 93.1 & 1.6 & 5.3 & 1.05 \\
\hline $108-662 \mathrm{~A}-18 \mathrm{H}-4,41$ & 160.11 & 92.5 & 1.7 & 5.8 & 0.99 \\
\hline $108-662 \mathrm{~A}-18 \mathrm{H}-4,50$ & 160.20 & 92.5 & 1.9 & 5.7 & 1.05 \\
\hline $108-662 \mathrm{~A}-18 \mathrm{H}-4,59$ & 160.29 & 90.9 & 2.1 & 7.0 & 1.0 \\
\hline $108-662 \mathrm{~A}-18 \mathrm{H}-4,71$ & 160.41 & 88.9 & 2.4 & 8.7 & 1.02 \\
\hline $108-662 \mathrm{~A}-18 \mathrm{H}-4,79$ & 160.49 & 88.4 & 2.4 & 9.2 & 1.00 \\
\hline $108-662 \mathrm{~A}-18 \mathrm{H}-4,89$ & 160.59 & 90.0 & 1.9 & 8.1 & 1.04 \\
\hline $108-662 \mathrm{~A}-18 \mathrm{H}-4,101$ & 160.71 & 93.8 & 1.8 & 4.4 & 1.01 \\
\hline $108-662 \mathrm{~A}-18 \mathrm{H}-4,110$ & 160.80 & 91.1 & 1.7 & 7.3 & 1.11 \\
\hline $108-662 \mathrm{~A}-18 \mathrm{H}-4,119$ & 160.89 & 92.3 & 1.8 & 5.9 & 1.02 \\
\hline $108-662 \mathrm{~A}-18 \mathrm{H}-4,131$ & 161.01 & 93.7 & 1.7 & 4.6 & 1.07 \\
\hline $108-662 \mathrm{~A}-18 \mathrm{H}-4,139$ & 161.09 & 93.7 & 1.6 & 4.7 & 1.04 \\
\hline $108-662 \mathrm{~A}-18 \mathrm{H}-4,147$ & 161.17 & 92.9 & 1.9 & 5.1 & 1.08 \\
\hline $108-662 \mathrm{~A}-18 \mathrm{H}-5,11$ & 161.31 & 89.8 & 1.9 & 8.3 & 1.07 \\
\hline $108-662 \mathrm{~A}-18 \mathrm{H}-5,19$ & 161.39 & 93.2 & 1.7 & 5.1 & 1.03 \\
\hline $108-662 \mathrm{~A}-18 \mathrm{H}-5,29$ & 161.49 & 92.8 & 1.9 & 5.3 & 1.08 \\
\hline $108-662 \mathrm{~A}-18 \mathrm{H}-5,41$ & 161.61 & 93.5 & 1.8 & 4.8 & 1.08 \\
\hline $108-662 \mathrm{~A}-18 \mathrm{H}-5,50$ & 161.70 & 91.1 & 1.8 & 7.1 & 1.11 \\
\hline $108-662 \mathrm{~A}-18 \mathrm{H}-5,59$ & 161.79 & 91.7 & 2.0 & 6.4 & 1.06 \\
\hline $108-662 \mathrm{~A}-18 \mathrm{H}-5,71$ & 161.91 & 91.3 & 2.0 & 6.7 & 1.06 \\
\hline $108-662 \mathrm{~A}-18 \mathrm{H}-5,79$ & 161.99 & 91.5 & 2.2 & 6.2 & 1.02 \\
\hline $108-662 \mathrm{~A}-18 \mathrm{H}-5,89$ & 162.09 & 92.4 & 1.4 & 6.2 & 1.07 \\
\hline $108-662 \mathrm{~A}-18 \mathrm{H}-5,101$ & 162.21 & 91.4 & 2.4 & 6.2 & 1.02 \\
\hline $108-662 \mathrm{~A}-18 \mathrm{H}-5,110$ & 162.30 & 90.5 & 1.6 & 7.9 & 1.17 \\
\hline 108-662A-18H-5, 119 & 162.39 & 90.6 & 2.0 & 7.3 & 1.01 \\
\hline $108-662 \mathrm{~A}-18 \mathrm{H}-5,131$ & 162.51 & 88.2 & 1.9 & 9.9 & 1.02 \\
\hline $108-662 \mathrm{~A}-18 \mathrm{H}-5,139$ & 162.59 & 92.4 & 2.0 & 5.6 & 1.01 \\
\hline $108-662 \mathrm{~A}-18 \mathrm{H}-5,147$ & 162.67 & 93.0 & 1.7 & 5.4 & 1.05 \\
\hline $108-662 \mathrm{~A}-18 \mathrm{H}-6,11$ & 162.81 & 92.6 & 1.7 & 5.7 & 1.04 \\
\hline $108-662 \mathrm{~A}-18 \mathrm{H}-6,19$ & 162.89 & 93.5 & 1.6 & 4.9 & 1.06 \\
\hline $108-662$ A- 18 H- 6,29 & 162.99 & 92.1 & 1.5 & 6.4 & 1.05 \\
\hline $108-662 \mathrm{~A}-18 \mathrm{H}-6,41$ & 163.11 & 93.1 & 1.6 & 5.3 & 1.06 \\
\hline $108-662 \mathrm{~A}-18 \mathrm{H}-6,50$ & 163.20 & 91.0 & 1.5 & 7.5 & 1.10 \\
\hline $108-662 \mathrm{~A}-18 \mathrm{H}-6,59$ & 163.29 & 92.9 & 1.0 & 6.0 & 1.06 \\
\hline $108-662 \mathrm{~A}-18 \mathrm{H}-6,71$ & 163.41 & 93.9 & 0.2 & 6.0 & 1.05 \\
\hline $108-662 \mathrm{~A}-18 \mathrm{H}-6,79$ & 163.49 & 93.1 & 1.5 & 5.4 & 1.02 \\
\hline $108-662 \mathrm{~A}-18 \mathrm{H}-6,89$ & 163.59 & 92.5 & 1.6 & 5.8 & 1.10 \\
\hline $108-662 \mathrm{~A}-18 \mathrm{H}-6,101$ & 163.71 & 92.0 & 1.6 & 6.4 & 1.09 \\
\hline $108-662 \mathrm{~A}-18 \mathrm{H}-6,110$ & 163.80 & 92.7 & 1.6 & 5.8 & 1.09 \\
\hline $108-662 \mathrm{~A}-18 \mathrm{H}-6,119$ & 163.89 & 95.1 & 0.9 & 4.0 & 0.99 \\
\hline $108-662 \mathrm{~A}-18 \mathrm{H}-6,131$ & 164.01 & 92.9 & 0.2 & 6.8 & 1.00 \\
\hline $108-662 \mathrm{~A}-18 \mathrm{H}-6,139$ & 164.09 & 92.5 & 0.3 & 7.2 & 0.98 \\
\hline $108-662 \mathrm{~A}-18 \mathrm{H}-6,147$ & 164.17 & 95.1 & 1.8 & 3.0 & 1.02 \\
\hline $108-662 \mathrm{~A}-18 \mathrm{H}-7,11$ & 164.31 & 93.3 & 0.4 & 6.3 & 1.01 \\
\hline $108-662 \mathrm{~A}-18 \mathrm{H}-7,19$ & 164.39 & 91.2 & 1.9 & 6.9 & 1.02 \\
\hline $108-662 \mathrm{~A}-18 \mathrm{H}-7,29$ & 164.49 & 91.2 & 0.3 & 8.5 & 1.07 \\
\hline $108-662 \mathrm{~A}-19 \mathrm{H}-1,29$ & 164.99 & 92.4 & 1.9 & 5.7 & 1.01 \\
\hline $108-662 \mathrm{~A}-19 \mathrm{H}-1,41$ & 165.11 & 90.3 & 0.3 & 9.4 & 1.00 \\
\hline $108-662 \mathrm{~A}-19 \mathrm{H}-1,50$ & 165.20 & 87.0 & 1.9 & 11.1 & 1.04 \\
\hline $108-662 \mathrm{~A}-19 \mathrm{H}-1,59$ & 165.29 & 89.6 & 2.0 & 8.5 & 1.02 \\
\hline $108-662 \mathrm{~A}-19 \mathrm{H}-1,71$ & 165.41 & 88.6 & 1.9 & 9.6 & 1.02 \\
\hline $108-662 \mathrm{~A}-19 \mathrm{H}-1,79$ & 165.49 & 91.4 & 1.5 & 7.1 & 1.01 \\
\hline $108-662 \mathrm{~A}-19 \mathrm{H}-1,89$ & 165.59 & 89.2 & 1.7 & 9.1 & 1.07 \\
\hline $108-662 \mathrm{~A}-19 \mathrm{H}-1,101$ & 165.71 & 88.9 & 2.1 & 8.9 & 1.03 \\
\hline $108-662 \mathrm{~A}-19 \mathrm{H}-1,110$ & 165.80 & 71.2 & 2.0 & 26.8 & 1.06 \\
\hline 108-662A-19H-1, 119 & 165.89 & 82.2 & 3.1 & 14.7 & 1.04 \\
\hline $108-662 \mathrm{~A}-19 \mathrm{H}-1,131$ & 166.01 & 78.0 & 3.9 & 18.1 & 0.96 \\
\hline 108-662A-19H-1, 139 & 166.09 & 79.5 & 4.3 & 16.3 & 0.94 \\
\hline $108-662 \mathrm{~A}-19 \mathrm{H}-1,146$ & 166.16 & 87.5 & 2.2 & 10.3 & 1.04 \\
\hline $108-662 \mathrm{~A}-19 \mathrm{H}-2,11$ & 166.31 & 89.2 & 1.8 & 9.0 & 1.01 \\
\hline $108-662 \mathrm{~A}-19 \mathrm{H}-2,19$ & 166.39 & 92.0 & 1.3 & 6.7 & 1.02 \\
\hline $108-662 \mathrm{~A}-19 \mathrm{H}-2,29$ & 166.49 & 91.6 & 1.7 & 6.7 & 1.06 \\
\hline $108-662 \mathrm{~A}-19 \mathrm{H}-2,41$ & 166.61 & 91.2 & 2.0 & 6.8 & 1.02 \\
\hline
\end{tabular}


Table 4 (continued).

\begin{tabular}{|c|c|c|c|c|c|}
\hline $\begin{array}{l}\text { Core, section, } \\
\text { interval }(\mathrm{cm})\end{array}$ & $\begin{array}{l}\text { Depth } \\
\text { (mbsf) }\end{array}$ & $\begin{array}{c}\mathrm{CaCO}_{3} \\
(\%)\end{array}$ & $\begin{array}{l}\mathrm{SiO}_{2} \\
(\%)\end{array}$ & $\begin{array}{c}\text { Terrigenous } \\
\text { fraction } \\
(\%)\end{array}$ & $\begin{array}{c}\begin{array}{c}\text { Dry-bulk } \\
\text { density } \\
\left(\mathrm{g} / \mathrm{cm}^{3}\right)\end{array}\end{array}$ \\
\hline $108-662 A-19 H-2,50$ & 166.70 & 87.7 & 1.8 & 10.5 & 1.02 \\
\hline $108-662 \mathrm{~A}-19 \mathrm{H}-2,59$ & 166.79 & 89.6 & 1.8 & 8.6 & 1.06 \\
\hline $108-662$ A- $19 \mathrm{H}-2,71$ & 166.91 & 88.7 & 1.7 & 9.7 & 1.04 \\
\hline $108-662 \mathrm{~A}-19 \mathrm{H}-2,79$ & 166.99 & 92.3 & 0.3 & 7.4 & 1.01 \\
\hline $108-662 \mathrm{~A}-19 \mathrm{H}-2,89$ & 167.09 & 90.3 & 1.6 & 8.1 & 1.05 \\
\hline $108-662 \mathrm{~A}-19 \mathrm{H}-2,101$ & 167.21 & 88.6 & 2.4 & 9.0 & 1.01 \\
\hline $108-662 \mathrm{~A}-19 \mathrm{H}-2,110$ & 167.30 & 88.0 & 3.1 & 8.9 & 1.03 \\
\hline $108-662 \mathrm{~A}-19 \mathrm{H}-2,119$ & 167.39 & 87.0 & 2.6 & 10.4 & 1.01 \\
\hline $108-662 \mathrm{~A}-19 \mathrm{H}-2,131$ & 167.51 & 91.5 & 1.7 & 6.8 & 1.03 \\
\hline $108-662 \mathrm{~A}-19 \mathrm{H}-2,139$ & 167.59 & 91.2 & 1.9 & 6.9 & 0.75 \\
\hline $108-662 \mathrm{~A}-19 \mathrm{H}-3,11$ & 167.81 & 90.3 & 2.1 & 7.6 & 1.03 \\
\hline $108-662 \mathrm{~A}-19 \mathrm{H}-3,19$ & 167.89 & 89.3 & 2.0 & 8.7 & 0.98 \\
\hline $108-662 \mathrm{~A}-19 \mathrm{H}-3,29$ & 167.99 & 89.4 & 2.6 & 8.0 & 1.03 \\
\hline $108-662 \mathrm{~A}-19 \mathrm{H}-3,41$ & 168.11 & 89.2 & 2.5 & 8.3 & 1.02 \\
\hline $108-662 \mathrm{~A}-19 \mathrm{H}-3,50$ & 168.20 & 81.0 & 1.9 & 17.1 & 1.07 \\
\hline $108-662 \mathrm{~A}-19 \mathrm{H}-3,59$ & 168.29 & 90.1 & 2.0 & 7.9 & 1.15 \\
\hline $108-662 \mathrm{~A}-19 \mathrm{H}-3,71$ & 168.41 & 89.1 & 1.7 & 9.2 & 1.03 \\
\hline $108-662 \mathrm{~A}-19 \mathrm{H}-3,79$ & 168.49 & 89.3 & 2.3 & 8.3 & 1.00 \\
\hline $108-662 \mathrm{~A}-19 \mathrm{H}-3,89$ & 168.59 & 90.5 & 2.5 & 7.0 & 1.03 \\
\hline $108-662 \mathrm{~A}-19 \mathrm{H}-3,101$ & 168.71 & 78.7 & 3.8 & 17.6 & 0.95 \\
\hline $108-662 A-19 H-3,110$ & 168.80 & 77.6 & 3.2 & 19.2 & 0.96 \\
\hline $108-662 \mathrm{~A}-19 \mathrm{H}-3,119$ & 168.89 & 86.8 & 3.1 & 10.1 & 0.94 \\
\hline $108-662 \mathrm{~A}-19 \mathrm{H}-3,131$ & 169.01 & 87.8 & 1.8 & 10.4 & 1.03 \\
\hline $108-662 \mathrm{~A}-19 \mathrm{H}-3,139$ & 169.09 & 88.6 & 2.0 & 9.4 & 1.05 \\
\hline $108-662 \mathrm{~A}-19 \mathrm{H}-3,146$ & 169.16 & 88.6 & 2.4 & 9.0 & 1.02 \\
\hline $108-662 \mathrm{~A}-19 \mathrm{H}-4,11$ & 169.31 & 73.7 & 3.4 & 22.8 & 1.09 \\
\hline $108-662 \mathrm{~A}-19 \mathrm{H}-4,19$ & 169.39 & 72.2 & 4.5 & 23.2 & 0.95 \\
\hline $108-662 \mathrm{~A}-19 \mathrm{H}-4,29$ & 169.49 & 83.8 & 3.3 & 12.9 & 0.92 \\
\hline $108-662 \mathrm{~A}-19 \mathrm{H}-4,41$ & 169.61 & 88.5 & 2.2 & 9.2 & 1.03 \\
\hline $108-662 \mathrm{~A}-19 \mathrm{H}-4,50$ & 169.70 & 89.8 & 1.5 & 8.6 & 1.07 \\
\hline $108-662 A-19 H-4,59$ & 169.79 & 88.4 & 2.4 & 9.1 & 1.05 \\
\hline $108-662 \mathrm{~A}-19 \mathrm{H}-4,71$ & 169.91 & 80.2 & 3.5 & 16.3 & 1.04 \\
\hline $108-662 \mathrm{~A}-19 \mathrm{H}-4,79$ & 169.99 & 82.4 & 4.1 & 13.6 & 0.99 \\
\hline $108-662 \mathrm{~A}-19 \mathrm{H}-4,89$ & 170.09 & 86.5 & 2.5 & 11.0 & 1.03 \\
\hline $108-662 \mathrm{~A}-19 \mathrm{H}-4,101$ & 170.21 & 88.8 & 2.2 & 8.9 & 1.03 \\
\hline $108-662 \mathrm{~A}-19 \mathrm{H}-4,110$ & 170.30 & 89.2 & 1.6 & 9.2 & 1.05 \\
\hline $108-662 \mathrm{~A}-19 \mathrm{H}-4,119$ & 170.39 & 84.7 & 2.5 & 12.9 & 1.05 \\
\hline $108-662 \mathrm{~A}-19 \mathrm{H}-4,131$ & 170.51 & 85.0 & 3.8 & 11.2 & 1.02 \\
\hline $108-662 \mathrm{~A}-19 \mathrm{H}-4,139$ & 170.59 & 87.1 & 3.4 & 9.6 & 1.00 \\
\hline $108-662 \mathrm{~A}-19 \mathrm{H}-4,146$ & 170.66 & 88.8 & 2.5 & 8.7 & 1.07 \\
\hline $108-662 \mathrm{~A}-19 \mathrm{H}-5,11$ & 170.81 & 89.2 & 1.9 & 8.9 & 1.05 \\
\hline $108-662 A-19 H-5,19$ & 170.89 & 89.0 & 1.9 & 9.1 & 1.03 \\
\hline $108-662 \mathrm{~A}-19 \mathrm{H}-5,29$ & 170.99 & 88.8 & 2.3 & 8.8 & 1.06 \\
\hline $108-662 \mathrm{~A}-19 \mathrm{H}-5,41$ & 171.11 & 89.1 & 1.9 & 9.0 & 1.07 \\
\hline $108-662 \mathrm{~A}-19 \mathrm{H}-5,50$ & 171.20 & 88.6 & 2.4 & 9.0 & 1.05 \\
\hline $108-662 \mathrm{~A}-19 \mathrm{H}-5,59$ & 171.29 & 89.6 & 2.9 & 7.5 & 1.04 \\
\hline $108-662 \mathrm{~A}-19 \mathrm{H}-5,71$ & 171.41 & 86.8 & 2.6 & 10.6 & 1.02 \\
\hline $108-662 \mathrm{~A}-19 \mathrm{H}-5,79$ & 171.50 & 88.8 & 2.9 & 8.3 & 1.02 \\
\hline $108-662 \mathrm{~A}-19 \mathrm{H}-5,89$ & 171.59 & 87.4 & 2.2 & 10.4 & 1.03 \\
\hline $108-662 \mathrm{~A}-19 \mathrm{H}-5,101$ & 171.71 & 90.7 & 2.0 & 7.3 & 1.01 \\
\hline $108-662 \mathrm{~A}-19 \mathrm{H}-5,110$ & 171.80 & 87.3 & 1.9 & 10.8 & $\begin{array}{l}1.01 \\
1.03\end{array}$ \\
\hline $108-662 \mathrm{~A}-19 \mathrm{H}-5,119$ & 171.89 & 82.4 & 3.2 & 14.4 & 1.07 \\
\hline $108-662 \mathrm{~A}-19 \mathrm{H}-5,131$ & 172.01 & 76.0 & 3.9 & 20.2 & 0.99 \\
\hline $108-662 \mathrm{~A}-19 \mathrm{H}-5,139$ & 172.09 & 85.7 & 3.7 & 10.5 & 1.01 \\
\hline $108-662 \mathrm{~A}-19 \mathrm{H}-5,146$ & 172.16 & 88.0 & 2.2 & 9.8 & 1.08 \\
\hline $108-662 A-19 H-6,11$ & 172.31 & 90.9 & 2.5 & 6.6 & 1.01 \\
\hline $108-662$ A- 19 H- 6,19 & 172.39 & 90.0 & 3.0 & 7.1 & 0.98 \\
\hline $108-662 \mathrm{~A}-19 \mathrm{H}-6,29$ & 172.49 & 87.4 & 3.2 & 9.4 & 1.00 \\
\hline $108-662 \mathrm{~A}-19 \mathrm{H}-6,41$ & 172.61 & 82.6 & 4.0 & 13.4 & 0.97 \\
\hline $108-662 \mathrm{~A}-19 \mathrm{H}-6,50$ & 172.70 & 87.8 & 3.2 & 9.0 & 1.00 \\
\hline $108-662 \mathrm{~A}-19 \mathrm{H}-6,59$ & 172.79 & 88.9 & 2.5 & 8.6 & 1.03 \\
\hline $108-662 \mathrm{~A}-19 \mathrm{H}-6,71$ & 172.91 & 89.9 & 2.2 & 7.9 & 1.00 \\
\hline $108-662$ A- 19 H- 6,79 & 172.99 & 88.7 & 2.2 & 9.1 & 0.99 \\
\hline $108-662 \mathrm{~A}-19 \mathrm{H}-6,89$ & 173.09 & 90.8 & 2.0 & 7.2 & 1.02 \\
\hline $108-662 \mathrm{~A}-19 \mathrm{H}-6,101$ & 173.21 & 90.0 & 0.4 & 9.6 & 1.01 \\
\hline $108-662 A-19 H-6,110$ & 173.30 & 87.1 & 3.0 & 9.9 & 1.00 \\
\hline 108-662A-19H-6, 119 & 173.39 & 85.0 & 3.7 & 11.3 & 0.97 \\
\hline $108-662 \mathrm{~A}-19 \mathrm{H}-6,131$ & 173.51 & 89.3 & 3.1 & 7.6 & 0.98 \\
\hline $108-662 A-19 H-6,139$ & 173.59 & 91.1 & 2.5 & 6.3 & 0.98 \\
\hline $108-662 A-19 H-6,146$ & 173.66 & 90.0 & 2.5 & 7.4 & 1.02 \\
\hline $108-662 \mathrm{~A}-19 \mathrm{H}-7,11$ & 173.81 & 90.2 & 2.6 & 7.2 & 1.02 \\
\hline $108-662 \mathrm{~A}-19 \mathrm{H}-7,19$ & 173.89 & 90.7 & 2.0 & 7.2 & 1.04 \\
\hline $108-662 \mathrm{~A}-19 \mathrm{H}-7,29$ & 173.99 & 90.4 & 2.5 & 7.1 & 1.10 \\
\hline $108-662 \mathrm{~A}-20 \mathrm{H}-1,11$ & 174.31 & 91.3 & 2.6 & 6.1 & 0.98 \\
\hline $108-662 \mathrm{~A}-20 \mathrm{H}-1,19$ & 174.39 & 89.3 & 2.3 & 8.4 & 0.94 \\
\hline $108-662 \mathrm{~A}-20 \mathrm{H}-1,29$ & 174.49 & 91.0 & 2.7 & 6.2 & 1.02 \\
\hline
\end{tabular}

Table 4 (continued).

\begin{tabular}{|c|c|c|c|c|c|}
\hline $\begin{array}{l}\text { Core, section, } \\
\text { interval }(\mathrm{cm})\end{array}$ & $\begin{array}{l}\text { Depth } \\
\text { (mbsf) }\end{array}$ & $\begin{array}{l}\mathrm{CaCO}_{3} \\
(\%)\end{array}$ & $\begin{array}{l}\mathrm{SiO}_{2} \\
(\%)\end{array}$ & $\begin{array}{l}\text { Terrigenous } \\
\text { fraction } \\
(\%)\end{array}$ & $\begin{array}{c}\begin{array}{c}\text { Dry-bulk } \\
\text { density } \\
\left(\mathrm{g} / \mathrm{cm}^{3}\right)\end{array}\end{array}$ \\
\hline $108-662 \mathrm{~A}-20 \mathrm{H}-1,41$ & 174.61 & 90.9 & 2.7 & 6.5 & 0.98 \\
\hline $108-662 \mathrm{~A}-20 \mathrm{H}-1,50$ & 174.70 & 90.4 & 2.1 & 7.5 & 0.97 \\
\hline $108-662 \mathrm{~A}-20 \mathrm{H}-1,59$ & 174.79 & 92.2 & 2.1 & 5.6 & 0.97 \\
\hline $108-662 \mathrm{~A}-20 \mathrm{H}-1,71$ & 174.91 & 91.5 & 2.5 & 6.1 & 0.94 \\
\hline $108-662 \mathrm{~A}-20 \mathrm{H}-1,79$ & 174.99 & 90.3 & 2.8 & 6.9 & 0.93 \\
\hline $108-662 \mathrm{~A}-20 \mathrm{H}-1,89$ & 175.09 & 87.7 & 2.7 & 9.6 & 0.75 \\
\hline $108-662 \mathrm{~A}-20 \mathrm{H}-1,101$ & 175.21 & 90.4 & 2.5 & 7.1 & 0.93 \\
\hline $108-662 \mathrm{~A}-20 \mathrm{H}-1,110$ & 175.30 & 89.2 & 1.8 & 9.0 & 0.93 \\
\hline $108-662 \mathrm{~A}-20 \mathrm{H}-1,119$ & 175.39 & 90.5 & 2.2 & 7.3 & 0.93 \\
\hline $108-662 \mathrm{~A}-20 \mathrm{H}-1,131$ & 175.51 & 90.2 & 2.3 & 7.5 & 0.94 \\
\hline $108-662 \mathrm{~A}-20 \mathrm{H}-1,139$ & 175.59 & 89.8 & 2.6 & 7.6 & 0.94 \\
\hline $108-662 \mathrm{~A}-20 \mathrm{H}-1,145$ & 175.65 & 91.1 & 2.3 & 6.7 & 0.97 \\
\hline $108-662 \mathrm{~A}-20 \mathrm{H}-2,11$ & 175.81 & 89.8 & 2.3 & 7.8 & 1.00 \\
\hline $108-662 \mathrm{~A}-20 \mathrm{H}-2,19$ & 175.89 & 90.9 & 2.9 & 6.2 & 0.94 \\
\hline $108-662 \mathrm{~A}-20 \mathrm{H}-2,29$ & 175.99 & 90.2 & 2.0 & 7.8 & 1.00 \\
\hline $108-662 \mathrm{~A}-20 \mathrm{H}-2,41$ & 176.11 & 87.3 & 3.2 & 9.5 & 0.97 \\
\hline $108-662 \mathrm{~A}-20 \mathrm{H}-2,50$ & 176.20 & 87.1 & 2.7 & 10.2 & 0.95 \\
\hline $108-662 \mathrm{~A}-20 \mathrm{H}-2,59$ & 176.29 & 88.8 & 3.0 & 8.2 & 1.00 \\
\hline $108-662 \mathrm{~A}-20 \mathrm{H}-2,71$ & 176.41 & 87.9 & 3.3 & 8.8 & 0.99 \\
\hline $108-662 \mathrm{~A}-20 \mathrm{H}-2,79$ & 176.49 & 88.7 & 2.9 & 8.4 & 0.97 \\
\hline $108-662 \mathrm{~A}-20 \mathrm{H}-2,89$ & 176.59 & 85.4 & 2.5 & 12.1 & 1.03 \\
\hline $108-662 \mathrm{~A}-20 \mathrm{H}-2,101$ & 176.71 & 90.0 & 1.9 & 8.1 & 1.02 \\
\hline $108-662 \mathrm{~A}-20 \mathrm{H}-2,110$ & 176.80 & 89.8 & 1.4 & 8.8 & 1.00 \\
\hline $108-662 \mathrm{~A}-20 \mathrm{H}-2,119$ & 176.89 & 89.2 & 2.3 & 8.5 & 1.00 \\
\hline $108-662 \mathrm{~A}-20 \mathrm{H}-2,131$ & 177.01 & 88.5 & 2.6 & 8.9 & 1.00 \\
\hline $108-662 \mathrm{~A}-20 \mathrm{H}-2,139$ & 177.09 & 88.4 & 3.0 & 8.6 & 1.00 \\
\hline $108-662 \mathrm{~A}-20 \mathrm{H}-2,146$ & 177.16 & 88.5 & 3.3 & 8.2 & 1.04 \\
\hline $108-662 \mathrm{~A}-20 \mathrm{H}-3,11$ & 177.31 & 88.8 & 3.0 & 8.3 & 0.99 \\
\hline $108-662 \mathrm{~A}-20 \mathrm{H}-3,19$ & 177.39 & 92.6 & 2.2 & 5.1 & 1.00 \\
\hline $108-662 \mathrm{~A}-20 \mathrm{H}-3,29$ & 177.49 & 91.4 & 2.0 & 6.6 & 1.04 \\
\hline $108-662 \mathrm{~A}-20 \mathrm{H}-3,41$ & 177.61 & 90.2 & 2.5 & 7.2 & 1.07 \\
\hline $108-662 \mathrm{~A}-20 \mathrm{H}-3,50$ & 177.70 & 91.6 & 2.3 & 6.1 & 1.04 \\
\hline $108-662 \mathrm{~A}-20 \mathrm{H}-3,59$ & 177.79 & 89.5 & 2.8 & 7.7 & 1.02 \\
\hline $108-662 \mathrm{~A}-20 \mathrm{H}-3,71$ & 177.91 & 91.5 & 2.4 & 6.0 & 1.02 \\
\hline $108-662 \mathrm{~A}-20 \mathrm{H}-3,79$ & 177.99 & 91.6 & 2.2 & 6.2 & 0.99 \\
\hline $108-662 \mathrm{~A}-20 \mathrm{H}-3,89$ & 178.09 & 92.4 & 1.8 & 5.8 & 1.03 \\
\hline $108-662 \mathrm{~A}-20 \mathrm{H}-3,101$ & 178.21 & 91.9 & 2.0 & 6.1 & 1.00 \\
\hline $108-662 \mathrm{~A}-20 \mathrm{H}-3,110$ & 178.30 & 88.7 & 2.7 & 8.6 & 0.99 \\
\hline $108-662 \mathrm{~A}-20 \mathrm{H}-3,119$ & 178.39 & 86.9 & 2.8 & 10.4 & 1.06 \\
\hline $108-662 \mathrm{~A}-20 \mathrm{H}-3,131$ & 178.51 & 86.6 & 3.3 & 10.1 & 1.10 \\
\hline $108-662 \mathrm{~A}-20 \mathrm{H}-3,139$ & 178.59 & 88.7 & 3.2 & 8.1 & 0.97 \\
\hline $108-662 \mathrm{~A}-20 \mathrm{H}-3,146$ & 178.66 & 89.3 & 2.8 & 7.9 & 1.03 \\
\hline $108-662 \mathrm{~A}-20 \mathrm{H}-4,11$ & 178.81 & 90.6 & 2.4 & 7.0 & 1.02 \\
\hline $108-662 \mathrm{~A}-20 \mathrm{H}-4,19$ & 178.89 & 91.8 & 2.3 & 5.9 & 1.01 \\
\hline $108-662 \mathrm{~A}-20 \mathrm{H}-4,29$ & 178.99 & 91.9 & 2.0 & 6.0 & 1.05 \\
\hline $108-662 \mathrm{~A}-20 \mathrm{H}-4,41$ & 179.11 & 90.6 & 2.1 & 7.4 & 1.04 \\
\hline $108-662 \mathrm{~A}-20 \mathrm{H}-4,50$ & 179.20 & 92.1 & 2.1 & 5.8 & 1.03 \\
\hline $108-662 \mathrm{~A}-20 \mathrm{H}-4,59$ & 179.29 & 92.3 & 1.9 & 5.9 & 1.05 \\
\hline $108-662 \mathrm{~A}-20 \mathrm{H}-4,71$ & 179.41 & 92.0 & 2.1 & 5.9 & 1.07 \\
\hline $108-662 \mathrm{~A}-20 \mathrm{H}-4,79$ & 179.49 & 92.2 & 2.2 & 5.6 & 1.00 \\
\hline $108-662 \mathrm{~A}-20 \mathrm{H}-4,89$ & 179.59 & 90.2 & 2.6 & 7.2 & 1.03 \\
\hline $108-662 \mathrm{~A}-20 \mathrm{H}-4,101$ & 179.71 & 90.5 & 2.2 & 7.3 & 1.02 \\
\hline $108-662 \mathrm{~A}-20 \mathrm{H}-4,110$ & 179.80 & 90.3 & 1.7 & 8.0 & 1.03 \\
\hline $108-662 \mathrm{~A}-20 \mathrm{H}-4,119$ & 179.89 & 92.8 & 2.1 & 5.1 & 1.08 \\
\hline $108-662 \mathrm{~A}-20 \mathrm{H}-4,131$ & 180.01 & 93.5 & 1.8 & 4.8 & 1.05 \\
\hline $108-662 \mathrm{~A}-20 \mathrm{H}-4,139$ & 180.09 & 92.7 & 2.2 & 5.1 & 1.01 \\
\hline $108-662 \mathrm{~A}-20 \mathrm{H}-4,146$ & 180.16 & 90.4 & 2.5 & 7.2 & 1.04 \\
\hline $108-662 \mathrm{~A}-20 \mathrm{H}-5,11$ & 180.31 & 88.6 & 3.0 & 8.4 & 1.04 \\
\hline $108-662 \mathrm{~A}-20 \mathrm{H}-5,19$ & 180.39 & 91.8 & 2.2 & 6.0 & 1.02 \\
\hline $108-662 \mathrm{~A}-20 \mathrm{H}-5,29$ & 180.49 & 93.1 & 2.0 & 4.9 & 1.14 \\
\hline $108-662 \mathrm{~A}-20 \mathrm{H}-5,41$ & 180.61 & 92.3 & 2.0 & 5.7 & 1.04 \\
\hline $108-662 \mathrm{~A}-20 \mathrm{H}-5,50$ & 180.70 & 93.4 & 1.7 & 4.9 & 1.03 \\
\hline $108-662 \mathrm{~A}-20 \mathrm{H}-5,59$ & 180.79 & 91.1 & 2.3 & 6.6 & 1.04 \\
\hline $108-662 \mathrm{~A}-20 \mathrm{H}-5,71$ & 180.91 & 84.4 & 3.3 & 12.3 & 1.06 \\
\hline $108-662 \mathrm{~A}-20 \mathrm{H}-5,79$ & 180.99 & 82.6 & 3.1 & 14.3 & 1.02 \\
\hline $108-662 \mathrm{~A}-20 \mathrm{H}-5,89$ & 181.09 & 85.5 & 3.3 & 11.2 & 1.34 \\
\hline $108-662 \mathrm{~A}-20 \mathrm{H}-5,101$ & 181.21 & 91.8 & 2.3 & 5.9 & 1.03 \\
\hline $108-662 \mathrm{~A}-20 \mathrm{H}-5,113$ & 181.33 & 91.9 & 1.7 & 6.5 & 1.06 \\
\hline $108-662 \mathrm{~A}-20 \mathrm{H}-5,119$ & 181.39 & 93.1 & 1.8 & 5.1 & 1.09 \\
\hline $108-662 \mathrm{~A}-20 \mathrm{H}-6,11$ & 181.81 & 88.4 & 2.6 & 9.1 & 1.03 \\
\hline $108-662 \mathrm{~A}-20 \mathrm{H}-6,19$ & 181.89 & 85.5 & 2.3 & 12.1 & 1.01 \\
\hline $108-662 \mathrm{~A}-20 \mathrm{H}-6,29$ & 181.99 & 92.2 & 2.0 & 5.8 & 1.06 \\
\hline $108-662 \mathrm{~A}-20 \mathrm{H}-6,41$ & 182.11 & 91.0 & 2.0 & 7.0 & 1.03 \\
\hline $108-662 \mathrm{~A}-20 \mathrm{H}-6,50$ & 182.20 & 92.1 & 2.0 & 5.9 & 1.04 \\
\hline $108-662 \mathrm{~A}-20 \mathrm{H}-6,59$ & 182.29 & 91.7 & 2.6 & 5.8 & 1.05 \\
\hline $108-662 \mathrm{~A}-20 \mathrm{H}-6,71$ & 182.41 & 88.7 & 3.1 & 8.2 & 1.12 \\
\hline
\end{tabular}


Table 4 (continued).

\begin{tabular}{|c|c|c|c|c|c|}
\hline $\begin{array}{l}\text { Core, section, } \\
\text { interval }(\mathrm{cm})\end{array}$ & $\begin{array}{l}\text { Depth } \\
\text { (mbsf) }\end{array}$ & $\begin{array}{c}\mathrm{CaCO}_{3} \\
(\%)\end{array}$ & $\begin{array}{c}\mathrm{SiO}_{2} \\
(\%)\end{array}$ & $\begin{array}{c}\text { Terrigenous } \\
\text { fraction } \\
(\%)\end{array}$ & $\begin{array}{c}\text { Dry-bulk } \\
\text { density } \\
\left(\mathrm{g} / \mathrm{cm}^{3}\right)\end{array}$ \\
\hline $108-662$ A- $20 \mathrm{H}-6,79$ & 182.49 & 87.3 & 3.4 & 9.3 & 1.02 \\
\hline $108-662 A-20 H-6,89$ & 182.59 & 87.1 & 3.1 & 9.9 & 1.03 \\
\hline $108-662 A-20 H-6,101$ & 182.71 & 90.2 & 3.3 & 6.5 & 0.97 \\
\hline $108-662 \mathrm{~A}-20 \mathrm{H}-6,110$ & 182.80 & 91.2 & 3.1 & 5.7 & 1.01 \\
\hline $108-662$ A-20H-6, 119 & 182.89 & 92.1 & 2.7 & 5.2 & 1.02 \\
\hline $108-662 \mathrm{~A}-20 \mathrm{H}-6,131$ & 183.01 & 92.8 & 2.2 & 5.0 & 1.03 \\
\hline 108-662A-20H-6, 139 & 183.09 & 92.6 & 2.2 & 5.2 & 1.00 \\
\hline $108-662 \mathrm{~A}-20 \mathrm{H}-6,146$ & 183.16 & 92.7 & 1.8 & 5.5 & 1.04 \\
\hline 108-662A-20H-7, 11 & 183.31 & 88.9 & 1.9 & 9.2 & 1.07 \\
\hline 108-662A-20H-7, 19 & 183.39 & 92.2 & 1.9 & 5.9 & 1.07 \\
\hline $108-662 \mathrm{~A}-20 \mathrm{H}-7,29$ & 183.49 & 91.4 & 1.9 & 6.7 & 1.25 \\
\hline $108-662 \mathrm{~A}-20 \mathrm{H}-7,41$ & 183.61 & 92.1 & 2.3 & 5.5 & 1.06 \\
\hline $108-662 \mathrm{~A}-21 \mathrm{H}-1,11$ & 183.81 & 86.8 & 2.8 & 10.4 & \\
\hline $108-662 \mathrm{~A}-21 \mathrm{H}-1,19$ & 183.89 & 89.1 & 2.6 & 8.3 & 0.99 \\
\hline $108-662 \mathrm{~A}-21 \mathrm{H}-1,29$ & 183.99 & 90.9 & 1.2 & 7.9 & \\
\hline 108-662A-21H-1, 41 & 184.11 & 92.9 & 1.3 & 5.8 & \\
\hline $108-662 \mathrm{~A}-21 \mathrm{H}-1,50$ & 184.20 & 93.2 & 1.3 & 5.5 & \\
\hline $108-662 A-21 H-1,59$ & 184.29 & 91.4 & 1.9 & 6.8 & \\
\hline 108-662A-21H-1, 71 & 184.41 & 88.7 & 2.1 & 9.2 & \\
\hline 108-662A-21H-1, 79 & 184.49 & 88.6 & 2.2 & 9.2 & 1.01 \\
\hline 108-662A-21H-1, 89 & 184.59 & 91.3 & 1.6 & 7.1 & \\
\hline $108-662 \mathrm{~A}-21 \mathrm{H}-1,101$ & 184.71 & 92.3 & 1.3 & 6.4 & \\
\hline $108-662 \mathrm{~A}-21 \mathrm{H}-1,108$ & 184.78 & 93.3 & 1.1 & 5.7 & \\
\hline $108-662 \mathrm{~A}-21 \mathrm{H}-1,119$ & 184.89 & 91.2 & 1.3 & 7.4 & \\
\hline $108-662 \mathrm{~A}-21 \mathrm{H}-1,131$ & 185.01 & 93.7 & 1.3 & 5.0 & \\
\hline $108-662 \mathrm{~A}-21 \mathrm{H}-1,139$ & 185.09 & 87.6 & 2.2 & 10.2 & 1.00 \\
\hline $108-662 \mathrm{~A}-21 \mathrm{H}-1,146$ & 185.16 & 91.9 & 1.8 & 6.3 & \\
\hline $108-662 \mathrm{~A}-21 \mathrm{H}-2,11$ & 185.31 & 90.9 & 2.4 & 6.7 & \\
\hline $108-662 \mathrm{~A}-21 \mathrm{H}-2,19$ & 185.39 & 89.2 & 2.3 & 8.5 & 0.99 \\
\hline $108-662 \mathrm{~A}-21 \mathrm{H}-2,29$ & 185.49 & 91.1 & 2.0 & 6.9 & \\
\hline $108-662 \mathrm{~A}-21 \mathrm{H}-2,41$ & 185.61 & 91.2 & 1.6 & 7.2 & \\
\hline $108-662 A-21 H-2,50$ & 185.70 & 91.4 & 1.5 & 7.1 & \\
\hline $108-662 A-21 H-2,59$ & 185.79 & 93.2 & 1.7 & 5.1 & \\
\hline 108-662A-21H-2, 71 & 185.91 & 91.8 & 1.7 & 6.5 & \\
\hline $108-662 A-21 H-2,79$ & 185.99 & 92.9 & 1.7 & 5.5 & 0.99 \\
\hline $108-662 A-21 H-2,89$ & 186.09 & 93.0 & 1.3 & 5.7 & \\
\hline $108-662 \mathrm{~A}-21 \mathrm{H}-2,101$ & 186.21 & 90.7 & 1.2 & 8.1 & \\
\hline $108-662 \mathrm{~A}-21 \mathrm{H}-2,108$ & 186.28 & 92.9 & 1.1 & 5.9 & \\
\hline $108-662 \mathrm{~A}-21 \mathrm{H}-2,119$ & 186.39 & 93.6 & 1.1 & 5.3 & \\
\hline $108-662 \mathrm{~A}-21 \mathrm{H}-2,131$ & 186.51 & 93.0 & 1.2 & 5.8 & \\
\hline $108-662 \mathrm{~A}-21 \mathrm{H}-2,139$ & 186.59 & 91.7 & 2.0 & 6.3 & 1.01 \\
\hline $108-662 \mathrm{~A}-21 \mathrm{H}-2,146$ & 186.66 & 91.4 & 1.9 & 6.7 & \\
\hline $108-662 A-21 H-3,11$ & 186.81 & 90.5 & 2.2 & 7.3 & \\
\hline $108-662 \mathrm{~A}-21 \mathrm{H}-3,19$ & 186.89 & 89.5 & 1.9 & 8.5 & 1.01 \\
\hline $108-662 A-21 H-3,29$ & 186.99 & 92.2 & 1.9 & 5.9 & \\
\hline $108-662 \mathrm{~A}-21 \mathrm{H}-3,41$ & 187.11 & 91.3 & 1.7 & 7.0 & \\
\hline $108-662 A-21 H-3,50$ & 187.20 & 92.1 & 1.5 & 6.4 & \\
\hline $108-662 A-21 H-3,59$ & 187.29 & 91.0 & 1.8 & 7.2 & \\
\hline $108-662 \mathrm{~A}-21 \mathrm{H}-3,71$ & 187.41 & 89.6 & 1.9 & 8.5 & \\
\hline $108-662 \mathrm{~A}-21 \mathrm{H}-3,79$ & 187.49 & 89.8 & 2.1 & 8.1 & 0.99 \\
\hline $108-662 \mathrm{~A}-21 \mathrm{H}-3,89$ & 187.59 & 93.2 & 1.1 & 5.8 & \\
\hline $108-662 \mathrm{~A}-21 \mathrm{H}-3,101$ & 187.71 & 94.3 & 1.0 & 4.7 & \\
\hline $108-662 \mathrm{~A}-21 \mathrm{H}-3,108$ & 187.78 & 94.3 & 1.3 & 4.4 & \\
\hline $108-662 \mathrm{~A}-21 \mathrm{H}-3,119$ & 187.89 & 93.7 & 1.0 & 5.3 & \\
\hline $108-662 \mathrm{~A}-21 \mathrm{H}-3,131$ & 188.01 & 92.3 & 1.6 & 6.1 & \\
\hline $108-662 \mathrm{~A}-21 \mathrm{H}-3,139$ & 188.09 & 92.1 & 1.6 & 6.4 & 1.02 \\
\hline $108-662 A-21 H-3,146$ & 188.16 & 81.3 & 1.5 & 17.1 & \\
\hline $108-662 \mathrm{~A}-21 \mathrm{H}-4,11$ & 188.31 & 91.5 & 1.5 & 7.0 & \\
\hline $108-662 A-21 H-4,19$ & 188.39 & 90.5 & 1.7 & 7.8 & 1.07 \\
\hline $108-662 \mathrm{~A}-21 \mathrm{H}-4,29$ & 188.49 & 88.8 & 2.3 & 8.9 & \\
\hline $108-662 A-21 H-4,41$ & 188.61 & 86.7 & 3.1 & 10.2 & \\
\hline $108-662 A-21 H-4,50$ & 188.70 & 86.8 & 2.5 & 10.8 & \\
\hline 108-662A-21H-4, 59 & 188.79 & 91.2 & 1.6 & 7.1 & \\
\hline $108-662 \mathrm{~A}-21 \mathrm{H}-4,71$ & 188.91 & 92.4 & 1.3 & 6.4 & \\
\hline $108-662 A-21 H-4,79$ & 188.99 & 92.1 & 1.3 & 6.6 & 0.98 \\
\hline $108-662 \mathrm{~A}-21 \mathrm{H}-4,89$ & 189.09 & 92.8 & 1.5 & 5.7 & \\
\hline $108-662 \mathrm{~A}-21 \mathrm{H}-4,101$ & 189.21 & 85.8 & 1.5 & 12.8 & \\
\hline $108-662 \mathrm{~A}-21 \mathrm{H}-4,108$ & 189.28 & 93.0 & 1.6 & 5.4 & \\
\hline $108-662 A-21 H-4,119$ & 189.39 & 93.1 & 1.0 & 5.9 & \\
\hline $108-662 \mathrm{~A}-21 \mathrm{H}-4,131$ & 189.51 & 91.7 & 1.2 & 7.1 & \\
\hline $108-662 \mathrm{~A}-21 \mathrm{H}-4,139$ & 189.59 & 93.6 & 1.0 & 5.4 & 1.03 \\
\hline $108-662 \mathrm{~A}-21 \mathrm{H}-4,146$ & 189.66 & 91.4 & 1.1 & 7.4 & \\
\hline $108-662 \mathrm{~A}-21 \mathrm{H}-5,11$ & 189.81 & 92.3 & 0.8 & 6.9 & \\
\hline $108-662 A-21 H-5,19$ & 189.89 & 91.5 & 1.1 & 7.3 & 1.01 \\
\hline $108-662 \mathrm{~A}-21 \mathrm{H}-5,29$ & 189.99 & 85.8 & 0.9 & 13.3 & \\
\hline $108-662 \mathrm{~A}-21 \mathrm{H}-5,41$ & 190.11 & 87.1 & 1.0 & 11.9 & \\
\hline
\end{tabular}

Table 4 (continued).

\begin{tabular}{|c|c|c|c|c|c|}
\hline $\begin{array}{l}\text { Core, section, } \\
\text { interval }(\mathrm{cm})\end{array}$ & $\begin{array}{l}\text { Depth } \\
\text { (mbsf) }\end{array}$ & $\begin{array}{c}\mathrm{CaCO}_{3} \\
(\%)\end{array}$ & $\begin{array}{l}\mathrm{SiO}_{2} \\
(\%)\end{array}$ & $\begin{array}{c}\text { Terrigenous } \\
\text { fraction } \\
(\%)\end{array}$ & $\begin{array}{l}\text { Dry-bulk } \\
\text { density } \\
\left(\mathrm{g} / \mathrm{cm}^{3}\right)\end{array}$ \\
\hline $108-662 \mathrm{~A}-21 \mathrm{H}-5,50$ & 190.20 & 92.6 & 1.4 & 6.0 & \\
\hline $108-662 \mathrm{~A}-21 \mathrm{H}-5,59$ & 190.29 & 91.3 & 1.0 & 7.7 & \\
\hline $108-662 \mathrm{~A}-21 \mathrm{H}-5,71$ & 190.41 & 90.8 & 1.4 & 7.8 & \\
\hline $108-662 \mathrm{~A}-21 \mathrm{H}-5,79$ & 190.49 & 90.3 & 1.3 & 8.3 & 1.02 \\
\hline $108-662 \mathrm{~A}-21 \mathrm{H}-5,89$ & 190.59 & 92.9 & 1.1 & 6.0 & \\
\hline $108-662 \mathrm{~A}-21 \mathrm{H}-5,101$ & 190.71 & 91.4 & 1.3 & 7.3 & \\
\hline $108-662 \mathrm{~A}-21 \mathrm{H}-5,108$ & 190.78 & 92.2 & 1.6 & 6.3 & \\
\hline $108-662 \mathrm{~A}-21 \mathrm{H}-5,119$ & 190.89 & 92.3 & 1.4 & 6.3 & \\
\hline $108-662 \mathrm{~A}-21 \mathrm{H}-5,131$ & 191.01 & 88.5 & 1.3 & 10.2 & \\
\hline $108-662 \mathrm{~A}-21 \mathrm{H}-5,136$ & 191.06 & 91.0 & 1.5 & 7.5 & 1.00 \\
\hline $108-662 \mathrm{~A}-21 \mathrm{H}-5,138$ & 191.08 & 90.8 & 1.6 & 7.7 & \\
\hline $108-662 \mathrm{~A}-21 \mathrm{H}-6,11$ & 191.31 & 92.0 & 1.9 & 6.1 & \\
\hline $108-662 \mathrm{~A}-21 \mathrm{H}-6,19$ & 191.39 & 71.3 & 2.1 & 26.6 & 1.02 \\
\hline $108-662 \mathrm{~A}-21 \mathrm{H}-6,29$ & 191.49 & 88.9 & 2.0 & 9.1 & \\
\hline $108-662 \mathrm{~A}-21 \mathrm{H}-6,39$ & 191.59 & 88.5 & 2.0 & 9.6 & \\
\hline $108-662 \mathrm{~A}-21 \mathrm{H}-6,50$ & 191.70 & 88.7 & 2.6 & 8.7 & \\
\hline $108-662 \mathrm{~A}-21 \mathrm{H}-6,59$ & 191.79 & 93.2 & 1.7 & 5.1 & \\
\hline $108-662 \mathrm{~A}-21 \mathrm{H}-6,71$ & 191.91 & 87.5 & 1.9 & 10.7 & \\
\hline $108-662 \mathrm{~A}-21 \mathrm{H}-6,79$ & 191.99 & 92.3 & 1.6 & 6.1 & 1.01 \\
\hline $108-662 \mathrm{~A}-21 \mathrm{H}-6,89$ & 192.09 & 93.5 & 1.3 & 5.1 & \\
\hline $108-662 \mathrm{~A}-21 \mathrm{H}-6,101$ & 192.21 & 92.0 & 1.7 & 6.3 & \\
\hline $108-662 \mathrm{~A}-21 \mathrm{H}-6,108$ & 192.28 & 92.3 & 1.9 & 5.8 & \\
\hline $108-662 \mathrm{~A}-21 \mathrm{H}-6,119$ & 192.39 & 92.9 & 1.6 & 5.5 & \\
\hline $108-662 \mathrm{~A}-21 \mathrm{H}-6,131$ & 192.51 & 95.7 & 1.5 & 2.8 & \\
\hline $108-662 \mathrm{~A}-21 \mathrm{H}-6,139$ & 192.59 & 77.7 & 1.5 & 20.8 & 1.23 \\
\hline $108-662 \mathrm{~A}-21 \mathrm{H}-6,144$ & 192.64 & 90.6 & 1.4 & 8.0 & \\
\hline $108-662 \mathrm{~A}-21 \mathrm{H}-7,11$ & 192.81 & 89.0 & 1.3 & 9.8 & \\
\hline $108-662 \mathrm{~A}-21 \mathrm{H}-7,29$ & 192.99 & 91.5 & 1.7 & 6.8 & \\
\hline $108-662 \mathrm{~A}-21 \mathrm{H}-7,39$ & 193.09 & 88.2 & 1.3 & 10.5 & \\
\hline $108-662 \mathrm{~A}-22 \mathrm{H}-1,50$ & 193.70 & 90.3 & 1.8 & 7.9 & \\
\hline $108-662 \mathrm{~A}-22 \mathrm{H}-1,59$ & 193.79 & 90.5 & & & \\
\hline $108-662 \mathrm{~A}-22 \mathrm{H}-1,71$ & 193.91 & 92.5 & 1.3 & 6.3 & \\
\hline $108-662 \mathrm{~A}-22 \mathrm{H}-1,79$ & 193.99 & 91.7 & 1.3 & 7.1 & 0.96 \\
\hline $108-662 \mathrm{~A}-22 \mathrm{H}-1,89$ & 194.09 & 92.0 & 1.3 & 6.7 & \\
\hline $108-662 \mathrm{~A}-22 \mathrm{H}-1,101$ & 194.21 & 91.8 & 1.3 & 6.9 & \\
\hline $108-662 \mathrm{~A}-22 \mathrm{H}-1,110$ & 194.30 & 92.7 & 1.6 & 5.7 & \\
\hline $108-662 \mathrm{~A}-22 \mathrm{H}-1,119$ & 194.39 & 91.6 & 1.3 & 7.2 & \\
\hline $108-662 \mathrm{~A}-22 \mathrm{H}-1,131$ & 194.51 & 88.8 & 1.4 & 9.8 & \\
\hline $108-662 \mathrm{~A}-22 \mathrm{H}-1,139$ & 194.59 & 91.5 & 1.6 & 7.0 & 1.01 \\
\hline $108-662 \mathrm{~A}-22 \mathrm{H}-1,146$ & 194.66 & 86.5 & 1.4 & 12.1 & \\
\hline $108-662 \mathrm{~A}-22 \mathrm{H}-2,11$ & 194.81 & 90.2 & 1.6 & 8.3 & \\
\hline $108-662 \mathrm{~A}-22 \mathrm{H}-2,19$ & 194.89 & 88.8 & 1.4 & 9.8 & 1.01 \\
\hline $108-662 \mathrm{~A}-22 \mathrm{H}-2,29$ & 194.99 & 91.3 & 1.3 & 7.5 & \\
\hline $108-662 \mathrm{~A}-22 \mathrm{H}-2,41$ & 195.11 & 92.5 & 1.0 & 6.6 & \\
\hline $108-662 \mathrm{~A}-22 \mathrm{H}-2,50$ & 195.20 & 91.5 & 1.2 & 7.3 & \\
\hline $108-662 \mathrm{~A}-22 \mathrm{H}-2,59$ & 195.29 & 92.6 & 1.1 & 6.3 & \\
\hline $108-662 \mathrm{~A}-22 \mathrm{H}-2,71$ & 195.41 & 90.2 & 1.2 & 8.6 & \\
\hline $108-662 \mathrm{~A}-22 \mathrm{H}-2,79$ & 195.49 & 91.7 & 1.4 & 6.9 & 1.01 \\
\hline $108-662 \mathrm{~A}-22 \mathrm{H}-2,89$ & 195.59 & 91.6 & 0.9 & 7.5 & \\
\hline $108-662 \mathrm{~A}-22 \mathrm{H}-2,101$ & 195.71 & 88.3 & 1.3 & 10.4 & \\
\hline $108-662 \mathrm{~A}-22 \mathrm{H}-2,110$ & 195.80 & 87.1 & 2.0 & 10.9 & \\
\hline $108-662 \mathrm{~A}-22 \mathrm{H}-2,119$ & 195.89 & 80.9 & 1.9 & 17.2 & \\
\hline $108-662 \mathrm{~A}-22 \mathrm{H}-2,131$ & 196.01 & 83.4 & 1.9 & 14.8 & \\
\hline $108-662 \mathrm{~A}-22 \mathrm{H}-2,139$ & 196.09 & 87.9 & 1.9 & 10.2 & 1.05 \\
\hline $108-662 \mathrm{~A}-22 \mathrm{H}-2,146$ & 196.16 & 91.4 & 1.1 & 7.5 & \\
\hline $108-662 \mathrm{~A}-22 \mathrm{H}-3,11$ & 196.31 & 90.3 & 1.3 & 8.4 & \\
\hline $108-662 \mathrm{~A}-22 \mathrm{H}-3,19$ & 196.39 & 91.4 & 1.2 & 7.4 & 1.02 \\
\hline $108-662 \mathrm{~A}-22 \mathrm{H}-3,29$ & 196.49 & 90.4 & 1.0 & 8.6 & \\
\hline $108-662 \mathrm{~A}-22 \mathrm{H}-3,41$ & 196.61 & 93.7 & 1.3 & 5.0 & \\
\hline $108-662 \mathrm{~A}-22 \mathrm{H}-3,50$ & 196.70 & 94.8 & 1.2 & 4.0 & \\
\hline $108-662 \mathrm{~A}-22 \mathrm{H}-3,59$ & 196.79 & 94.3 & 1.3 & 4.4 & \\
\hline $108-662 \mathrm{~A}-22 \mathrm{H}-3,71$ & 196.91 & 92.2 & 1.5 & 6.2 & \\
\hline $108-662 \mathrm{~A}-22 \mathrm{H}-3,79$ & 196.99 & 85.7 & 1.3 & 13.0 & 1.01 \\
\hline $108-662 \mathrm{~A}-22 \mathrm{H}-3,89$ & 197.09 & 92.8 & 1.6 & 5.6 & \\
\hline $108-662 \mathrm{~A}-22 \mathrm{H}-3,101$ & 197.21 & 94.2 & 2.1 & 3.8 & \\
\hline $108-662 \mathrm{~A}-22 \mathrm{H}-3,110$ & 197.30 & 92.5 & 1.7 & 5.7 & \\
\hline $108-662 \mathrm{~A}-22 \mathrm{H}-3,119$ & 197.39 & 93.1 & 1.6 & 5.4 & \\
\hline $108-662 \mathrm{~A}-22 \mathrm{H}-3,131$ & 197.51 & 78.6 & 1.7 & 19.7 & \\
\hline $108-662 \mathrm{~A}-22 \mathrm{H}-3,139$ & 197.59 & 93.8 & 1.7 & 4.6 & 1.00 \\
\hline $108-662 \mathrm{~A}-22 \mathrm{H}-3,146$ & 197.66 & 94.0 & 1.6 & 4.4 & \\
\hline $108-662 \mathrm{~A}-22 \mathrm{H}-4,11$ & 197.81 & 92.2 & 1.9 & 5.9 & \\
\hline $108-662 \mathrm{~A}-22 \mathrm{H}-4,19$ & 197.89 & 92.2 & 1.5 & 6.3 & 1.04 \\
\hline $108-662 \mathrm{~A}-22 \mathrm{H}-4,29$ & 197.99 & 90.5 & 2.2 & 7.3 & \\
\hline $108-662 \mathrm{~A}-22 \mathrm{H}-4,41$ & 198.11 & 91.4 & 2.1 & 6.5 & \\
\hline $108-662 \mathrm{~A}-22 \mathrm{H}-4,50$ & 198.20 & 91.2 & 1.4 & 7.4 & \\
\hline $108-662 \mathrm{~A}-22 \mathrm{H}-4,59$ & 198.29 & 92.7 & 1.7 & 5.6 & \\
\hline
\end{tabular}


Table 4 (continued).

\begin{tabular}{|c|c|c|c|c|c|}
\hline $\begin{array}{l}\text { Core, section, } \\
\text { interval }(\mathrm{cm})\end{array}$ & $\begin{array}{l}\text { Depth } \\
\text { (mbsf) }\end{array}$ & $\begin{array}{c}\mathrm{CaCO}_{3} \\
(\%)\end{array}$ & $\underset{(\%)}{\mathrm{SiO}_{2}}$ & $\begin{array}{c}\text { Terrigenous } \\
\text { fraction } \\
(\%)\end{array}$ & $\begin{array}{c}\text { Dry-bulk } \\
\text { density } \\
\left(\mathrm{g} / \mathrm{cm}^{3}\right)\end{array}$ \\
\hline $108-662 \mathrm{~A}-22 \mathrm{H}-4,71$ & 198.41 & 93.1 & 1.7 & 5.2 & \\
\hline $108-662 \mathrm{~A}-22 \mathrm{H}-4,79$ & 198.49 & 91.2 & 1.5 & 7.3 & 0.98 \\
\hline $108-662 \mathrm{~A}-22 \mathrm{H}-4,89$ & 198.59 & 93.0 & 1.5 & 5.6 & \\
\hline $108-662 \mathrm{~A}-22 \mathrm{H}-4,101$ & 198.71 & 92.3 & 1.4 & 6.3 & \\
\hline $108-662 \mathrm{~A}-22 \mathrm{H}-4,110$ & 198.80 & 91.7 & 1.3 & 7.0 & \\
\hline $108-662 \mathrm{~A}-22 \mathrm{H}-4,119$ & 198.89 & 91.6 & 1.4 & 7.0 & \\
\hline $108-662 \mathrm{~A}-22 \mathrm{H}-4,131$ & 199.01 & 89.9 & 1.4 & 8.6 & \\
\hline $108-662 \mathrm{~A}-22 \mathrm{H}-4,139$ & 199.09 & 90.8 & 1.8 & 7.3 & 0.99 \\
\hline $108-662 \mathrm{~A}-22 \mathrm{H}-4,146$ & 199.16 & 92.3 & 1.5 & 6.2 & \\
\hline $108-662 \mathrm{~A}-22 \mathrm{H}-5,11$ & 199.31 & 90.8 & 1.5 & 7.7 & \\
\hline $108-662 A-22 H-5,19$ & 199.39 & 91.3 & 1.3 & 7.4 & 0.99 \\
\hline $108-662 A-22 H-5,29$ & 199.49 & 91.0 & 1.1 & 7.9 & \\
\hline $108-662 A-22 \mathrm{H}-5,41$ & 199.61 & 91.2 & 1.3 & 7.6 & \\
\hline $108-662 A-22 \mathrm{H}-5,50$ & 199.70 & 91.1 & 1.4 & 7.5 & \\
\hline $108-662 A-22 H-5,59$ & 199.79 & 95.0 & 0.8 & 4.3 & \\
\hline $108-662 A-22 \mathrm{H}-5,71$ & 199.91 & 87.6 & 1.3 & 11.1 & \\
\hline $108-662 \mathrm{~A}-22 \mathrm{H}-5,79$ & 199.99 & 84.3 & 1.9 & 13.8 & 1.01 \\
\hline $108-662 A-22 H-5,89$ & 200.09 & 82.4 & 1.7 & 15.9 & \\
\hline $108-662 \mathrm{~A}-22 \mathrm{H}-5,101$ & 200.21 & 85.5 & 1.6 & 13.0 & \\
\hline $108-662 \mathrm{~A}-22 \mathrm{H}-5,110$ & 200.30 & 87.9 & 1.5 & 10.6 & \\
\hline $108-662 \mathrm{~A}-22 \mathrm{H}-5,119$ & 200.39 & 90.7 & 1.1 & 8.2 & \\
\hline $108-662 \mathrm{~A}-22 \mathrm{H}-5,131$ & 200.51 & 90.4 & 0.9 & 8.7 & \\
\hline $108-662 A-22 H-5,139$ & 200.59 & 91.5 & 1.3 & 7.2 & 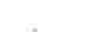 \\
\hline $108-662 \mathrm{~A}-22 \mathrm{H}-5,146$ & 200.66 & 91.4 & 1.1 & 7.5 & \\
\hline $108-662 \mathrm{~A}-22 \mathrm{H}-6,11$ & 200.81 & 90.4 & 1.3 & 8.2 & \\
\hline $108-662 A-22 H-6,19$ & 200.89 & 90.0 & 1.8 & 8.2 & 1.01 \\
\hline $108-662 A-22 H-6,29$ & 200.99 & 85.0 & 1.5 & 13.6 & \\
\hline $108-662 \mathrm{~A}-22 \mathrm{H}-6,41$ & 201.11 & 86.7 & 1.5 & 11.8 & \\
\hline $108-662 A-22 H-6,50$ & 201.20 & 90.8 & 1.5 & 7.6 & \\
\hline $108-662 A-22 \mathrm{H}-6,59$ & 201.29 & 91.3 & 1.1 & 7.7 & \\
\hline $108-662 A-22 H-6,71$ & 201.41 & 91.9 & 1.2 & 6.9 & \\
\hline $108-662 A-22 H-6,79$ & 201.49 & 91.3 & 1.2 & 7.5 & 1.00 \\
\hline $108-662 A-22 H-6,89$ & 201.59 & 93.8 & 1.3 & 4.9 & \\
\hline $108-662 \mathrm{~A}-22 \mathrm{H}-6,101$ & 201.71 & 91.7 & 1.5 & 6.8 & \\
\hline $108-662 \mathrm{~A}-22 \mathrm{H}-6,110$ & 201.80 & 92.4 & 1.5 & 6.1 & \\
\hline $108-662 \mathrm{~A}-22 \mathrm{H}-6,119$ & 201.89 & 91.8 & 1.8 & 6.4 & \\
\hline $108-662 \mathrm{~A}-22 \mathrm{H}-6,131$ & 202.01 & 91.7 & 1.5 & 6.8 & \\
\hline $108-662 A-22 H-6,139$ & 202.09 & 91.4 & 1.5 & 7.1 & 1.00 \\
\hline $108-662 \mathrm{~A}-22 \mathrm{H}-6,146$ & 202.16 & 92.1 & 1.4 & 6.4 & \\
\hline $108-662 \mathrm{~A}-22 \mathrm{H}-7,11$ & 202.31 & 92.1 & 1.3 & 6.6 & \\
\hline $108-662 \mathrm{~A}-22 \mathrm{H}-7,19$ & 202.39 & 92.4 & 1.5 & 6.1 & 0.97 \\
\hline $108-662 \mathrm{~A}-22 \mathrm{H}-7,29$ & 202.49 & 91.5 & 1.7 & 6.8 & \\
\hline $108-662 \mathrm{~A}-22 \mathrm{H}-7,41$ & 202.61 & 93.3 & 1.8 & 4.9 & \\
\hline $108-662 \mathrm{~A}-22 \mathrm{H}-7,50$ & 202.70 & 94.3 & 1.9 & 3.8 & \\
\hline $108-662 \mathrm{~A}-22 \mathrm{H}-7,59$ & 202.79 & 91.7 & 1.7 & 6.6 & \\
\hline
\end{tabular}

Table 5 . Percentages of carbonate, opal, and terrigenous fraction, and dry-bulk densities at Hole 663A.

\begin{tabular}{cccccc}
\hline $\begin{array}{c}\text { Core, section, } \\
\text { interval }(\mathrm{cm})\end{array}$ & $\begin{array}{c}\text { Depth } \\
\text { (mbs) }\end{array}$ & $\begin{array}{c}\mathrm{CaCO}_{3} \\
(\%)\end{array}$ & $\begin{array}{c}\mathrm{SiO}_{2} \\
(\%)\end{array}$ & $\begin{array}{c}\text { Terrigenous } \\
\text { fraction } \\
(\%)\end{array}$ & $\begin{array}{c}\text { Dry-bulk } \\
\text { density } \\
\left(\mathrm{g} / \mathrm{cm}^{3}\right)\end{array}$ \\
\hline $108-663 \mathrm{~A}-1 \mathrm{H}-1,11$ & 0.11 & 87.8 & 2.7 & 9.5 & 0.78 \\
$108-663 \mathrm{~A}-1 \mathrm{H}-1,19$ & 0.19 & 87.6 & 3.2 & 9.2 & 0.74 \\
$108-663 \mathrm{~A}-1 \mathrm{H}-1,29$ & 0.29 & 81.0 & 4.7 & 14.3 & 0.69 \\
$108-663 \mathrm{~A}-1 \mathrm{H}-1,41$ & 0.41 & 74.6 & 4.9 & 20.5 & 0.66 \\
$108-663 \mathrm{~A}-1 \mathrm{H}-1,50$ & 0.50 & 69.5 & 7.6 & 22.9 & 0.64 \\
$108-663 \mathrm{~A}-1 \mathrm{H}-1,59$ & 0.59 & 76.2 & 5.7 & 18.2 & 0.53 \\
$108-663 \mathrm{~A}-1 \mathrm{H}-1,71$ & 0.71 & 62.4 & 5.7 & 31.9 & 0.49 \\
$108-663 \mathrm{~A}-1 \mathrm{H}-1,79$ & 0.79 & 74.7 & 5.7 & 19.6 & 0.47 \\
$108-663 \mathrm{~A}-1 \mathrm{H}-1,89$ & 0.89 & 71.9 & 6.3 & 21.9 & 0.44 \\
$108-663 \mathrm{~A}-1 \mathrm{H}-1,101$ & 1.01 & 67.3 & 6.6 & 26.1 & 0.44 \\
$108-663 \mathrm{~A}-1 \mathrm{H}-1,110$ & 1.10 & 66.5 & 7.4 & 26.1 & 0.46 \\
$108-663 \mathrm{~A}-1 \mathrm{H}-1,119$ & 1.19 & 68.5 & 6.7 & 24.8 & 0.44 \\
$108-663 \mathrm{~A}-1 \mathrm{H}-1,131$ & 1.31 & 73.1 & 5.9 & 21.1 & 0.51 \\
$108-663 \mathrm{~A}-1 \mathrm{H}-1,139$ & 1.39 & 78.9 & 5.5 & 15.6 & 0.57 \\
$108-663 \mathrm{~A}-1 \mathrm{H}-1,146$ & 1.46 & 77.7 & 5.5 & 16.8 & 0.66 \\
$108-663 \mathrm{~A}-1 \mathrm{H}-2,11$ & 1.61 & 70.0 & 4.5 & 25.6 & 0.66 \\
$108-663 \mathrm{~A}-1 \mathrm{H}-2,19$ & 1.69 & 83.2 & 4.2 & 12.6 & 0.68 \\
$108-663 \mathrm{~A}-1 \mathrm{H}-2,29$ & 1.79 & 81.1 & 4.5 & 14.4 & 0.70 \\
$108-663 \mathrm{~A}-1 \mathrm{H}-2,41$ & 1.91 & 76.0 & 6.3 & 17.7 & 0.61 \\
$108-663 \mathrm{~A}-1 \mathrm{H}-2,50$ & 2.00 & 79.2 & 5.2 & 15.6 & 0.69 \\
$108-663 \mathrm{~A}-1 \mathrm{H}-2,59$ & 2.09 & 77.4 & 5.7 & 16.9 & 0.62
\end{tabular}

Table 5 (continued).

\begin{tabular}{|c|c|c|c|c|c|}
\hline $\begin{array}{l}\text { Core, section, } \\
\text { interval }(\mathrm{cm})\end{array}$ & $\begin{array}{l}\text { Depth } \\
\text { (mbsf) }\end{array}$ & $\begin{array}{c}\mathrm{CaCO}_{3} \\
(\%)\end{array}$ & $\begin{array}{l}\mathrm{SiO}_{2} \\
(\%)\end{array}$ & $\begin{array}{l}\text { Terrigenous } \\
\text { fraction } \\
(\%)\end{array}$ & $\begin{array}{c}\text { Dry-bulk } \\
\text { density } \\
\left(\mathrm{g} / \mathrm{cm}^{3}\right)\end{array}$ \\
\hline $108-663 \mathrm{~A}-1 \mathrm{H}-2,71$ & 2.21 & 77.5 & 5.1 & 17.4 & 0.62 \\
\hline $108-663 \mathrm{~A}-1 \mathrm{H}-2,79$ & 2.29 & 75.0 & 3.1 & 21.8 & 0.62 \\
\hline $108-663 \mathrm{~A}-1 \mathrm{H}-2,89$ & 2.39 & 80.7 & 4.4 & 14.9 & 0.71 \\
\hline $108-663 \mathrm{~A}-1 \mathrm{H}-2,101$ & 2.51 & 80.7 & 4.8 & 14.5 & 0.69 \\
\hline $108-663 \mathrm{~A}-1 \mathrm{H}-2,110$ & 2.60 & 78.1 & 5.3 & 16.6 & 0.74 \\
\hline 108-663A-1H-2, 119 & 2.69 & 75.9 & 6.1 & 18.1 & 0.63 \\
\hline $108-663 \mathrm{~A}-1 \mathrm{H}-2,131$ & 2.81 & 72.2 & 6.7 & 21.1 & 0.59 \\
\hline $108-663 \mathrm{~A}-1 \mathrm{H}-2,139$ & 2.89 & 70.4 & 6.9 & 22.6 & 0.54 \\
\hline $108-663 \mathrm{~A}-1 \mathrm{H}-3,11$ & 3.11 & 70.5 & 7.5 & 22.0 & 0.57 \\
\hline $108-663 \mathrm{~A}-1 \mathrm{H}-3,19$ & 3.19 & 71.7 & 6.4 & 22.0 & 0.55 \\
\hline $108-663 \mathrm{~A}-1 \mathrm{H}-3,29$ & 3.29 & 63.2 & 7.4 & 29.4 & 0.57 \\
\hline $108-663 \mathrm{~A}-1 \mathrm{H}-3,41$ & 3.41 & 75.7 & 4.7 & 19.6 & 0.66 \\
\hline $108-663 \mathrm{~A}-1 \mathrm{H}-3,50$ & 3.50 & 84.6 & 3.1 & 12.3 & 0.72 \\
\hline $108-663 \mathrm{~A}-1 \mathrm{H}-3,59$ & 3.59 & 86.8 & 3.0 & 10.3 & 0.73 \\
\hline $108-663 \mathrm{~A}-1 \mathrm{H}-3,71$ & 3.71 & 76.4 & 5.4 & 18.1 & 0.68 \\
\hline $108-663 \mathrm{~A}-1 \mathrm{H}-3,79$ & 3.79 & 84.4 & 3.0 & 12.6 & 0.71 \\
\hline $108-663 \mathrm{~A}-1 \mathrm{H}-3,89$ & 3.89 & 83.6 & 3.2 & 13.2 & 0.70 \\
\hline 108-663A-1H-3, 101 & 4.01 & 74.4 & 3.5 & 22.1 & 0.69 \\
\hline $108-663 \mathrm{~A}-1 \mathrm{H}-3,110$ & 4.10 & 85.0 & 3.3 & 11.7 & 0.72 \\
\hline $108-663 \mathrm{~A}-1 \mathrm{H}-3,119$ & 4.19 & 85.9 & 2.8 & 11.3 & 0.77 \\
\hline $108-663 \mathrm{~A}-1 \mathrm{H}-3,131$ & 4.31 & 81.3 & 2.8 & 15.8 & 0.74 \\
\hline 108-663A-1H-3, 139 & 4.39 & 83.6 & 3.1 & 13.4 & 0.66 \\
\hline $108-663 \mathrm{~A}-1 \mathrm{H}-3,146$ & 4.46 & 83.1 & 3.5 & 13.4 & 0.67 \\
\hline $108-663 \mathrm{~A}-2 \mathrm{H}-1,11$ & 4.81 & 75.4 & 6.6 & 18.0 & 0.55 \\
\hline $108-663 \mathrm{~A}-2 \mathrm{H}-1,21$ & 4.91 & 64.8 & 8.4 & 26.8 & 0.48 \\
\hline $108-663 \mathrm{~A}-2 \mathrm{H}-1,29$ & 4.99 & 66.2 & 7.3 & 26.5 & 0.49 \\
\hline $108-663 \mathrm{~A}-2 \mathrm{H}-1,40$ & 5.09 & 66.1 & 7.1 & 26.8 & 0.52 \\
\hline $108-663 \mathrm{~A}-2 \mathrm{H}-1,50$ & 5.19 & 85.2 & 3.5 & 11.3 & 0.72 \\
\hline $108-663 \mathrm{~A}-2 \mathrm{H}-1,59$ & 5.29 & 86.1 & 3.5 & 10.3 & 0.71 \\
\hline $108-663 \mathrm{~A}-2 \mathrm{H}-1,71$ & 5.41 & 77.0 & 3.7 & 19.3 & 0.68 \\
\hline $108-663 \mathrm{~A}-2 \mathrm{H}-1,79$ & 5.49 & 76.2 & 3.7 & 20.2 & 0.70 \\
\hline $108-663 \mathrm{~A}-2 \mathrm{H}-1,89$ & 5.59 & 85.3 & 4.3 & 10.4 & 0.68 \\
\hline $108-663 \mathrm{~A}-2 \mathrm{H}-1,101$ & 5.71 & 72.1 & 4.5 & 23.4 & 0.59 \\
\hline $108-663 \mathrm{~A}-2 \mathrm{H}-1,110$ & 5.80 & 76.7 & 5.0 & 18.4 & 0.68 \\
\hline $108-663 \mathrm{~A}-2 \mathrm{H}-1,119$ & 5.89 & 73.9 & 6.0 & 20.1 & 0.54 \\
\hline $108-663 \mathrm{~A}-2 \mathrm{H}-1,131$ & 6.01 & 83.8 & 5.6 & 10.6 & 0.56 \\
\hline $108-663 \mathrm{~A}-2 \mathrm{H}-1,139$ & 6.09 & 75.8 & 4.6 & 19.6 & 0.64 \\
\hline $108-663 \mathrm{~A}-2 \mathrm{H}-2,11$ & 6.31 & 66.2 & 6.1 & 27.7 & 0.61 \\
\hline 108-663A-2H-2, 19 & 6.39 & 85.4 & 3.3 & 11.4 & 0.76 \\
\hline $108-663 \mathrm{~A}-2 \mathrm{H}-2,29$ & 6.49 & 88.8 & 2.1 & 9.1 & 0.76 \\
\hline $108-663 \mathrm{~A}-2 \mathrm{H}-2,41$ & 6.61 & 78.5 & 3.8 & 17.7 & 0.71 \\
\hline $108-663 \mathrm{~A}-2 \mathrm{H}-2,50$ & 6.70 & 80.2 & 4.0 & 15.8 & 0.78 \\
\hline $108-663 \mathrm{~A}-2 \mathrm{H}-2,59$ & 6.79 & 80.3 & 3.7 & 16.0 & 0.62 \\
\hline $108-663 \mathrm{~A}-2 \mathrm{H}-2,71$ & 6.91 & 86.6 & 3.0 & 10.4 & 0.77 \\
\hline $108-663 \mathrm{~A}-2 \mathrm{H}-2,79$ & 6.99 & 86.5 & 3.2 & 10.3 & 0.78 \\
\hline $108-663 \mathrm{~A}-2 \mathrm{H}-2,89$ & 7.09 & 79.6 & 3.1 & 17.3 & 0.71 \\
\hline 108-663A-2H-2, 101 & 7.21 & 81.0 & 4.4 & 14.6 & 0.63 \\
\hline $108-663 \mathrm{~A}-2 \mathrm{H}-2,110$ & 7.30 & 68.9 & 5.5 & 25.6 & 0.64 \\
\hline $108-663 \mathrm{~A}-2 \mathrm{H}-2,119$ & 7.39 & 63.7 & 6.2 & 30.0 & 0.53 \\
\hline $108-663 \mathrm{~A}-2 \mathrm{H}-2,131$ & 7.51 & 71.0 & 5.6 & 23.4 & 0.56 \\
\hline $108-663 \mathrm{~A}-2 \mathrm{H}-2,139$ & 7.59 & 82.7 & 4.5 & 12.8 & 0.68 \\
\hline $108-663 \mathrm{~A}-2 \mathrm{H}-2,146$ & 7.66 & 83.5 & 4.5 & 12.0 & 0.67 \\
\hline $108-663 \mathrm{~A}-2 \mathrm{H}-3,11$ & 7.81 & 88.9 & 3.2 & 7.8 & 0.72 \\
\hline $108-663 \mathrm{~A}-2 \mathrm{H}-3,19$ & 7.89 & 74.9 & 5.3 & 19.7 & 0.64 \\
\hline $108-663 \mathrm{~A}-2 \mathrm{H}-3,29$ & 7.99 & 80.4 & 4.5 & 15.0 & 0.72 \\
\hline $108-663 \mathrm{~A}-2 \mathrm{H}-3,41$ & 8.11 & 78.6 & 4.5 & 16.9 & 0.66 \\
\hline $108-663 \mathrm{~A}-2 \mathrm{H}-3,50$ & 8.20 & 77.2 & 4.9 & 18.0 & 0.66 \\
\hline $108-663 \mathrm{~A}-2 \mathrm{H}-3,59$ & 8.29 & 81.9 & 4.6 & 13.5 & 0.64 \\
\hline $108-663 \mathrm{~A}-2 \mathrm{H}-3,71$ & 8.41 & 82.8 & 3.6 & 13.6 & 0.66 \\
\hline $108-663 \mathrm{~A}-2 \mathrm{H}-3,79$ & 8.49 & 82.1 & 4.3 & 13.6 & 0.70 \\
\hline $108-663 \mathrm{~A}-2 \mathrm{H}-3,89$ & 8.59 & 78.4 & 4.7 & 16.9 & 0.67 \\
\hline $108-663 \mathrm{~A}-2 \mathrm{H}-3,101$ & 8.71 & 69.0 & 6.1 & 25.0 & 0.61 \\
\hline $108-663 \mathrm{~A}-2 \mathrm{H}-3,110$ & 8.80 & 74.8 & 7.2 & 18.0 & 0.68 \\
\hline $108-663 \mathrm{~A}-2 \mathrm{H}-3,119$ & 8.89 & 77.5 & 5.6 & 16.9 & 0.63 \\
\hline $108-663 \mathrm{~A}-2 \mathrm{H}-3,131$ & 9.01 & 72.4 & 6.5 & 21.1 & 0.55 \\
\hline $108-663 \mathrm{~A}-2 \mathrm{H}-3,139$ & 9.09 & 65.7 & 8.2 & 26.2 & 0.48 \\
\hline $108-663 \mathrm{~A}-2 \mathrm{H}-3,146$ & 9.16 & 67.5 & 7.5 & 25.0 & 0.54 \\
\hline $108-663 \mathrm{~A}-2 \mathrm{H}-4,11$ & 9.31 & 68.3 & 6.4 & 25.3 & 0.60 \\
\hline $108-663 \mathrm{~A}-2 \mathrm{H}-4,19$ & 9.39 & 78.1 & 4.1 & 17.9 & 0.72 \\
\hline $108-663 \mathrm{~A}-2 \mathrm{H}-4,29$ & 9.49 & 83.5 & 3.5 & 13.0 & 0.74 \\
\hline $108-663 \mathrm{~A}-2 \mathrm{H}-4,41$ & 9.61 & 87.9 & 3.7 & 8.4 & 0.71 \\
\hline $108-663 \mathrm{~A}-2 \mathrm{H}-4,50$ & 9.70 & 86.6 & 3.3 & 10.1 & 0.81 \\
\hline $108-663 \mathrm{~A}-2 \mathrm{H}-4,59$ & 9.79 & 86.2 & 2.8 & 11.0 & 0.80 \\
\hline $108-663 \mathrm{~A}-2 \mathrm{H}-4,71$ & 9.91 & 84.0 & 3.6 & 12.4 & 0.77 \\
\hline $108-663 \mathrm{~A}-2 \mathrm{H}-4,79$ & 9.99 & 84.4 & 2.9 & 12.7 & 0.75 \\
\hline $108-663 \mathrm{~A}-2 \mathrm{H}-4,89$ & 10.09 & 78.4 & 3.8 & 17.8 & 0.73 \\
\hline $108-663 \mathrm{~A}-2 \mathrm{H}-4,101$ & 10.21 & 81.1 & 3.7 & 15.3 & 0.75 \\
\hline
\end{tabular}


Table 5 (continued).

\begin{tabular}{|c|c|c|c|c|c|}
\hline $\begin{array}{l}\text { Core, section, } \\
\text { interval }(\mathrm{cm})\end{array}$ & $\begin{array}{l}\text { Depth } \\
\text { (mbsf) }\end{array}$ & $\begin{array}{c}\mathrm{CaCO}_{3} \\
(\%)\end{array}$ & $\underset{(\%)}{\mathrm{SiO}_{2}}$ & $\begin{array}{c}\text { Terrigenous } \\
\text { fraction } \\
(\%)\end{array}$ & $\begin{array}{c}\begin{array}{c}\text { Dry-bulk } \\
\text { density }\end{array} \\
\left(\mathrm{g} / \mathrm{cm}^{3}\right)\end{array}$ \\
\hline $108-663 \mathrm{~A}-2 \mathrm{H}-4,110$ & 10.30 & 82.2 & 4.0 & 13.8 & 0.77 \\
\hline $108-663 \mathrm{~A}-2 \mathrm{H}-4,119$ & 10.39 & 76.9 & 5.5 & 17.6 & 0.66 \\
\hline $108-663 \mathrm{~A}-2 \mathrm{H}-4,131$ & 10.51 & 84.1 & 3.2 & 12.6 & 0.78 \\
\hline $108-663 \mathrm{~A}-2 \mathrm{H}-4,139$ & 10.59 & 82.9 & 2.3 & 14.8 & 0.80 \\
\hline $108-663 \mathrm{~A}-2 \mathrm{H}-4,146$ & 10.66 & 86.7 & 2.7 & 10.6 & 0.81 \\
\hline $108-663 \mathrm{~A}-2 \mathrm{H}-5,11$ & 10.81 & 73.1 & 5.1 & 21.8 & 0.69 \\
\hline $108-663 \mathrm{~A}-2 \mathrm{H}-5,19$ & 10.89 & 82.6 & 4.6 & 12.8 & 0.74 \\
\hline $108-663 \mathrm{~A}-2 \mathrm{H}-5,29$ & 10.99 & 85.3 & 3.8 & 10.9 & 0.82 \\
\hline $108-663 \mathrm{~A}-2 \mathrm{H}-5,41$ & 11.11 & 88.7 & 3.0 & 8.3 & 0.82 \\
\hline $108-663 \mathrm{~A}-2 \mathrm{H}-5,50$ & 11.20 & 78.4 & 2.9 & 18.7 & 0.85 \\
\hline $108-663 \mathrm{~A}-2 \mathrm{H}-5,59$ & 11.29 & 83.1 & 3.7 & 13.2 & 0.83 \\
\hline 108-663A-2H-5, 71 & 11.41 & 64.5 & 6.8 & 28.7 & 0.63 \\
\hline $108-663$ A-2H-5, 79 & 11.49 & 64.6 & 5.7 & 29.7 & 0.59 \\
\hline $108-663 \mathrm{~A}-2 \mathrm{H}-5,89$ & 11.59 & 67.2 & 6.3 & 26.5 & 0.59 \\
\hline $108-663 \mathrm{~A}-2 \mathrm{H}-5,101$ & 11.71 & 77.1 & 5.5 & 17.5 & 0.66 \\
\hline $108-663 \mathrm{~A}-2 \mathrm{H}-5,110$ & 11.80 & 81.6 & 5.1 & 13.3 & 0.69 \\
\hline $108-663 \mathrm{~A}-2 \mathrm{H}-5,118$ & 11.88 & 79.4 & 4.5 & 16.1 & 0.68 \\
\hline 108-663A-2H-6, 11 & 12.31 & 64.3 & 5.0 & 30.7 & 0.70 \\
\hline $108-663 \mathrm{~A}-2 \mathrm{H}-6,19$ & 12.39 & 78.0 & 5.2 & 16.8 & 0.68 \\
\hline $108-663 \mathrm{~A}-2 \mathrm{H}-6,29$ & 12.49 & 79.7 & 4.7 & 15.6 & 0.84 \\
\hline $108-663 \mathrm{~A}-2 \mathrm{H}-6,41$ & 12.61 & 80.1 & 6.1 & 13.9 & 0.69 \\
\hline $108-663 \mathrm{~A}-2 \mathrm{H}-6,50$ & 12.70 & 82.4 & 4.5 & 13.1 & 0.73 \\
\hline $108-663 \mathrm{~A}-2 \mathrm{H}-6,59$ & 12.79 & 81.0 & 4.7 & 14.3 & 0.70 \\
\hline $108-663 \mathrm{~A}-2 \mathrm{H}-6,71$ & 12.91 & 81.8 & 3.8 & 14.4 & 0.72 \\
\hline 108-663A-2H-6, 79 & 12.99 & 80.3 & 4.5 & 15.2 & 0.78 \\
\hline $108-663 \mathrm{~A}-2 \mathrm{H}-6,89$ & 13.09 & 85.5 & 3.9 & 10.7 & 0.81 \\
\hline $108-663$ A- 2 H- 6,101 & 13.21 & 80.7 & 2.3 & 17.0 & 0.84 \\
\hline $108-663 \mathrm{~A}-2 \mathrm{H}-6,110$ & 13.30 & 89.3 & 2.7 & 8.0 & 0.88 \\
\hline $108-663 \mathrm{~A}-2 \mathrm{H}-6,119$ & 13.39 & 83.7 & 3.9 & 12.4 & 0.77 \\
\hline $108-663 \mathrm{~A}-2 \mathrm{H}-6,131$ & 13.51 & 90.7 & 1.8 & 7.5 & 0.89 \\
\hline $108-663$ A-2H-6, 139 & 13.59 & 88.2 & 2.1 & 9.7 & 0.91 \\
\hline $108-663 \mathrm{~A}-2 \mathrm{H}-6,146$ & 13.66 & 90.4 & 2.2 & 7.4 & 0.84 \\
\hline $108-663 \mathrm{~A}-2 \mathrm{H}-7,11$ & 13.81 & 84.3 & 3.2 & 12.6 & 0.82 \\
\hline $108-663 \mathrm{~A}-2 \mathrm{H}-7,19$ & 13.89 & 83.0 & 4.0 & 13.1 & 0.75 \\
\hline $108-663 \mathrm{~A}-2 \mathrm{H}-7,29$ & 13.99 & 69.0 & 5.1 & 25.9 & 0.65 \\
\hline $108-663 \mathrm{~A}-3 \mathrm{H}-1,19$ & 14.39 & 88.0 & 2.1 & 9.9 & 0.87 \\
\hline $108-663 \mathrm{~A}-3 \mathrm{H}-1,29$ & 14.49 & 85.8 & 2.5 & 11.7 & 0.90 \\
\hline $108-663 \mathrm{~A}-3 \mathrm{H}-1,41$ & 14.61 & 64.1 & 6.6 & 29.3 & 0.61 \\
\hline $108-663 \mathrm{~A}-3 \mathrm{H}-1,50$ & 14.70 & 75.6 & 5.5 & 18.9 & 0.69 \\
\hline $108-663 \mathrm{~A}-3 \mathrm{H}-1,57$ & 14.77 & 76.6 & 5.6 & 17.8 & 0.71 \\
\hline $108-663 \mathrm{~A}-3 \mathrm{H}-1,71$ & 14.91 & 82.9 & 4.7 & 12.4 & 0.70 \\
\hline $108-663 \mathrm{~A}-3 \mathrm{H}-1,79$ & 14.99 & 81.0 & 4.7 & 14.3 & 0.70 \\
\hline $108-663 \mathrm{~A}-3 \mathrm{H}-1,89$ & 15.09 & 74.5 & 6.0 & 19.5 & 0.73 \\
\hline $108-663 A-3 H-1,101$ & 15.21 & 74.1 & 7.3 & 18.6 & 0.61 \\
\hline $108-663 \mathrm{~A}-3 \mathrm{H}-1,110$ & 15.30 & 81.1 & 4.1 & 14.8 & 0.72 \\
\hline $108-663 \mathrm{~A}-3 \mathrm{H}-1,119$ & 15.39 & 81.6 & 3.6 & 14.9 & 0.71 \\
\hline $108-663 \mathrm{~A}-3 \mathrm{H}-1,131$ & 15.51 & 88.9 & 2.9 & 8.2 & 0.80 \\
\hline $108-663 \mathrm{~A}-3 \mathrm{H}-1,139$ & 15.59 & 88.0 & 2.6 & 9.4 & 0.80 \\
\hline $108-663 \mathrm{~A}-3 \mathrm{H}-1,146$ & 15.66 & 83.4 & 3.5 & 13.2 & 0.76 \\
\hline $108-663 \mathrm{~A}-3 \mathrm{H}-2,11$ & 15.81 & 77.4 & 5.0 & 17.6 & 0.69 \\
\hline $108-663 \mathrm{~A}-3 \mathrm{H}-2,19$ & 15.89 & 66.6 & 5.8 & 27.7 & 0.60 \\
\hline $108-663 \mathrm{~A}-3 \mathrm{H}-2,29$ & 15.99 & 79.7 & 4.4 & 15.9 & 0.69 \\
\hline $108-663 \mathrm{~A}-3 \mathrm{H}-2,41$ & 16.11 & 83.8 & 4.1 & 12.1 & 0.72 \\
\hline $108-663 \mathrm{~A}-3 \mathrm{H}-2,50$ & 16.20 & 75.3 & 5.8 & 18.9 & 0.67 \\
\hline $108-663 \mathrm{~A}-3 \mathrm{H}-2,59$ & 16.29 & 86.3 & 3.7 & 10.0 & 0.75 \\
\hline $108-663 \mathrm{~A}-3 \mathrm{H}-2,71$ & 16.41 & 84.6 & 3.4 & 12.0 & 0.77 \\
\hline $108-663 \mathrm{~A}-3 \mathrm{H}-2,79$ & 16.49 & 80.3 & 5.0 & 14.7 & 0.73 \\
\hline $108-663 \mathrm{~A}-3 \mathrm{H}-2,89$ & 16.59 & 79.8 & 5.1 & 15.1 & 0.68 \\
\hline $108-663 \mathrm{~A}-3 \mathrm{H}-2,101$ & 16.71 & 78.8 & 4.6 & 16.6 & 0.69 \\
\hline $108-663 \mathrm{~A}-3 \mathrm{H}-2,110$ & 16.80 & 69.7 & 5.1 & 25.1 & 0.66 \\
\hline $108-663 \mathrm{~A}-3 \mathrm{H}-2,119$ & 16.89 & 65.3 & 7.5 & 27.3 & 0.59 \\
\hline $108-663 \mathrm{~A}-3 \mathrm{H}-2,131$ & 17.01 & 89.5 & 3.0 & 7.5 & 0.83 \\
\hline $108-663 \mathrm{~A}-3 \mathrm{H}-2,139$ & 17.09 & 86.7 & 4.0 & 9.4 & 0.84 \\
\hline $108-663 \mathrm{~A}-3 \mathrm{H}-2,146$ & 17.16 & 89.8 & 2.1 & 8.1 & 0.89 \\
\hline $108-663 \mathrm{~A}-3 \mathrm{H}-3,11$ & 17.31 & 90.8 & 2.3 & 7.0 & 0.90 \\
\hline $108-663 \mathrm{~A}-3 \mathrm{H}-3,19$ & 17.39 & 84.3 & 2.7 & 12.9 & 0.86 \\
\hline $108-663 \mathrm{~A}-3 \mathrm{H}-3,29$ & 17.49 & 91.1 & 2.1 & 6.8 & 0.94 \\
\hline $108-663 \mathrm{~A}-3 \mathrm{H}-3,41$ & 17.61 & 87.8 & 2.7 & 9.5 & 0.89 \\
\hline $108-663 \mathrm{~A}-3 \mathrm{H}-3,50$ & 17.70 & 89.5 & 2.4 & 8.1 & 0.91 \\
\hline $108-663 \mathrm{~A}-3 \mathrm{H}-3,59$ & 17.79 & 86.9 & 2.7 & 10.3 & 0.88 \\
\hline $108-663 \mathrm{~A}-3 \mathrm{H}-3,71$ & 17.91 & 87.0 & 2.8 & 10.3 & 0.88 \\
\hline $108-663 \mathrm{~A}-3 \mathrm{H}-3,79$ & 17.99 & 86.6 & 2.7 & 10.7 & 0.88 \\
\hline $108-663 \mathrm{~A}-3 \mathrm{H}-3,89$ & 18.09 & 85.6 & 2.9 & 11.5 & 0.88 \\
\hline $108-663 \mathrm{~A}-3 \mathrm{H}-3,101$ & 18.21 & 87.5 & 2.8 & 9.7 & 0.87 \\
\hline $108-663 \mathrm{~A}-3 \mathrm{H}-3,110$ & 18.30 & 87.2 & 3.0 & 9.8 & 0.86 \\
\hline $108-663 \mathrm{~A}-3 \mathrm{H}-3,119$ & 18.39 & 88.5 & 3.0 & 8.5 & 0.83 \\
\hline
\end{tabular}

Table 5 (continued).

\begin{tabular}{|c|c|c|c|c|c|}
\hline $\begin{array}{l}\text { Core, section, } \\
\text { interval }(\mathrm{cm})\end{array}$ & $\begin{array}{l}\text { Depth } \\
\text { (mbsf) }\end{array}$ & $\begin{array}{c}\mathrm{CaCO}_{3} \\
(\%)\end{array}$ & $\begin{array}{l}\mathrm{SiO}_{2} \\
(\%)\end{array}$ & $\begin{array}{l}\text { Terrigenous } \\
\text { fraction } \\
(\%)\end{array}$ & $\begin{array}{c}\text { Dry-bulk } \\
\text { density } \\
\left(\mathrm{g} / \mathrm{cm}^{3}\right)\end{array}$ \\
\hline $108-663 \mathrm{~A}-3 \mathrm{H}-3,131$ & 18.51 & 89.1 & 2.6 & 8.3 & 0.87 \\
\hline $108-663 \mathrm{~A}-3 \mathrm{H}-3,139$ & 18.59 & 89.5 & 2.4 & 8.1 & 0.86 \\
\hline $108-663 \mathrm{~A}-3 \mathrm{H}-3,146$ & 18.66 & 92.6 & 2.1 & 5.2 & 0.87 \\
\hline $108-663 \mathrm{~A}-3 \mathrm{H}-4,11$ & 18.81 & 86.2 & 2.5 & 11.4 & 0.89 \\
\hline $108-663 \mathrm{~A}-3 \mathrm{H}-4,19$ & 18.89 & 90.3 & 2.4 & 7.3 & 0.86 \\
\hline $108-663 \mathrm{~A}-3 \mathrm{H}-4,29$ & 18.99 & 90.1 & 2.5 & 7.4 & 0.87 \\
\hline $108-663 \mathrm{~A}-3 \mathrm{H}-4,41$ & 19.11 & 84.4 & 3.8 & 11.8 & 0.84 \\
\hline $108-663 \mathrm{~A}-3 \mathrm{H}-4,50$ & 19.20 & 87.2 & 3.7 & 9.1 & 0.79 \\
\hline $108-663 \mathrm{~A}-3 \mathrm{H}-4,59$ & 19.29 & 85.5 & 3.4 & 11.1 & 0.64 \\
\hline $108-663 \mathrm{~A}-3 \mathrm{H}-4,71$ & 19.41 & 87.7 & 3.1 & 9.3 & 0.80 \\
\hline $108-663 \mathrm{~A}-3 \mathrm{H}-4,79$ & 19.49 & 89.8 & 3.2 & 7.0 & 0.81 \\
\hline $108-663 \mathrm{~A}-3 \mathrm{H}-4,89$ & 19.59 & 79.9 & 5.5 & 14.6 & 0.71 \\
\hline $108-663 \mathrm{~A}-3 \mathrm{H}-4,101$ & 19.71 & 86.8 & 3.4 & 9.8 & 0.79 \\
\hline $108-663 \mathrm{~A}-3 \mathrm{H}-4,110$ & 19.80 & 87.2 & 3.0 & 9.8 & 0.84 \\
\hline $108-663 \mathrm{~A}-3 \mathrm{H}-4,119$ & 19.89 & 84.4 & 3.3 & 12.3 & 0.81 \\
\hline $108-663 \mathrm{~A}-3 \mathrm{H}-4,131$ & 20.01 & 85.5 & 4.3 & 10.3 & 0.78 \\
\hline $108-663 \mathrm{~A}-3 \mathrm{H}-4,139$ & 20.09 & 83.4 & 3.8 & 12.8 & 0.79 \\
\hline $108-663 \mathrm{~A}-3 \mathrm{H}-4,146$ & 20.16 & 82.9 & 4.2 & 12.9 & 0.78 \\
\hline $108-663 \mathrm{~A}-3 \mathrm{H}-5,11$ & 20.31 & 75.3 & 3.9 & 20.8 & 0.71 \\
\hline $108-663 \mathrm{~A}-3 \mathrm{H}-5,19$ & 20.39 & 86.9 & 3.3 & 9.8 & 0.88 \\
\hline $108-663 \mathrm{~A}-3 \mathrm{H}-5,29$ & 20.49 & 84.3 & 4.0 & 11.7 & 0.87 \\
\hline $108-663 \mathrm{~A}-3 \mathrm{H}-5,41$ & 20.61 & 86.1 & 3.7 & 10.1 & 0.84 \\
\hline $108-663 \mathrm{~A}-3 \mathrm{H}-5,50$ & 20.70 & 87.1 & 2.5 & 10.5 & 1.27 \\
\hline $108-663 \mathrm{~A}-3 \mathrm{H}-5,59$ & 20.79 & 86.9 & 3.5 & 9.6 & 0.85 \\
\hline $108-663 \mathrm{~A}-3 \mathrm{H}-5,71$ & 20.91 & 82.9 & 4.3 & 12.9 & 0.81 \\
\hline $108-663 \mathrm{~A}-3 \mathrm{H}-5,79$ & 20.99 & 81.8 & 4.6 & 13.5 & 0.77 \\
\hline $108-663 \mathrm{~A}-3 \mathrm{H}-5,89$ & 21.09 & 82.8 & 3.7 & 13.6 & 0.79 \\
\hline $108-663 \mathrm{~A}-3 \mathrm{H}-5,101$ & 21.21 & 72.5 & 5.8 & 21.7 & 0.70 \\
\hline $108-663 \mathrm{~A}-3 \mathrm{H}-5,110$ & 21.30 & 80.3 & 4.7 & 15.1 & 0.77 \\
\hline $108-663 \mathrm{~A}-3 \mathrm{H}-5,119$ & 21.39 & 82.8 & 4.2 & 13.0 & 0.83 \\
\hline $108-663 \mathrm{~A}-3 \mathrm{H}-5,131$ & 21.51 & 82.3 & 4.2 & 13.5 & 0.79 \\
\hline $108-663 \mathrm{~A}-3 \mathrm{H}-5,139$ & 21.59 & 87.3 & 3.5 & 9.2 & 0.84 \\
\hline $108-663 \mathrm{~A}-3 \mathrm{H}-5,146$ & 21.66 & 86.5 & 4.0 & 9.5 & 0.83 \\
\hline $108-663 \mathrm{~A}-3 \mathrm{H}-6,11$ & 21.81 & 86.5 & 2.9 & 10.6 & 0.86 \\
\hline $108-663 \mathrm{~A}-3 \mathrm{H}-6,19$ & 21.89 & 80.2 & 4.4 & 15.4 & 0.77 \\
\hline $108-663 \mathrm{~A}-3 \mathrm{H}-6,29$ & 21.99 & 73.9 & 6.7 & 19.4 & 0.67 \\
\hline $108-663 \mathrm{~A}-3 \mathrm{H}-6,41$ & 22.11 & 75.0 & 6.6 & 18.4 & 0.67 \\
\hline $108-663 \mathrm{~A}-3 \mathrm{H}-6,50$ & 22.20 & 80.7 & 5.5 & 13.9 & 0.71 \\
\hline $108-663 \mathrm{~A}-3 \mathrm{H}-6,59$ & 22.29 & 78.3 & 4.9 & 16.8 & 0.72 \\
\hline $108-663 \mathrm{~A}-3 \mathrm{H}-6,71$ & 22.41 & 74.7 & 6.8 & 18.5 & 0.69 \\
\hline $108-663 \mathrm{~A}-3 \mathrm{H}-6,79$ & 22.49 & 76.6 & 5.9 & 17.5 & 0.69 \\
\hline $108-663 \mathrm{~A}-3 \mathrm{H}-6,89$ & 22.59 & 83.8 & 4.4 & 11.8 & 0.74 \\
\hline $108-663 \mathrm{~A}-3 \mathrm{H}-6,101$ & 22.71 & 84.3 & 4.2 & 11.6 & 0.76 \\
\hline $108-663 \mathrm{~A}-3 \mathrm{H}-6,110$ & 22.80 & 83.5 & 2.8 & 13.7 & 1.03 \\
\hline $108-663 \mathrm{~A}-3 \mathrm{H}-6,119$ & 22.89 & 88.4 & 3.3 & 8.3 & 0.83 \\
\hline $108-663 \mathrm{~A}-3 \mathrm{H}-6,131$ & 23.01 & 85.3 & 3.4 & 11.4 & 0.81 \\
\hline $108-663 \mathrm{~A}-3 \mathrm{H}-6,139$ & 23.09 & 85.5 & 4.2 & 10.3 & 0.77 \\
\hline $108-663 \mathrm{~A}-3 \mathrm{H}-6,146$ & 23.16 & 85.4 & 3.9 & 10.7 & 0.80 \\
\hline $108-663 \mathrm{~A}-3 \mathrm{H}-7,11$ & 23.31 & 79.4 & 5.7 & 14.9 & 0.72 \\
\hline $108-663 \mathrm{~A}-3 \mathrm{H}-7,19$ & 23.39 & 79.2 & 5.9 & 14.9 & 0.68 \\
\hline $108-663 \mathrm{~A}-3 \mathrm{H}-7,41$ & 23.61 & 71.9 & 6.3 & 21.8 & 0.67 \\
\hline $108-663 \mathrm{~A}-4 \mathrm{H}-1,11$ & 23.81 & 89.1 & 2.6 & 8.3 & 0.83 \\
\hline $108-663 \mathrm{~A}-4 \mathrm{H}-1,19$ & 23.89 & 89.4 & 2.1 & 8.6 & 0.79 \\
\hline $108-663 \mathrm{~A}-4 \mathrm{H}-1,29$ & 23.99 & 85.7 & 2.9 & 11.4 & 0.81 \\
\hline $108-663 \mathrm{~A}-4 \mathrm{H}-1,41$ & 24.11 & 85.8 & 3.5 & 10.7 & 0.83 \\
\hline $108-663 \mathrm{~A}-4 \mathrm{H}-1,50$ & 24.20 & 84.7 & 2.9 & 12.4 & 0.80 \\
\hline $108-663 \mathrm{~A}-4 \mathrm{H}-1,59$ & 24.29 & 87.1 & 2.1 & 10.8 & 0.81 \\
\hline $108-663 \mathrm{~A}-4 \mathrm{H}-1,71$ & 24.41 & 75.4 & 5.2 & 19.4 & 0.73 \\
\hline $108-663 \mathrm{~A}-4 \mathrm{H}-1,79$ & 24.49 & 67.7 & 7.6 & 24.7 & 0.61 \\
\hline $108-663 \mathrm{~A}-4 \mathrm{H}-1,89$ & 24.59 & 76.6 & 5.9 & 17.5 & 0.66 \\
\hline $108-663 \mathrm{~A}-4 \mathrm{H}-1,101$ & 24.71 & 81.5 & 5.6 & 12.9 & 0.71 \\
\hline $108-663 \mathrm{~A}-4 \mathrm{H}-1,110$ & 24.80 & 83.0 & 4.1 & 12.9 & 0.78 \\
\hline $108-663 \mathrm{~A}-4 \mathrm{H}-1,119$ & 24.89 & 86.3 & 3.7 & 10.0 & 0.76 \\
\hline $108-663 \mathrm{~A}-4 \mathrm{H}-1,131$ & 25.01 & 88.1 & 2.8 & 9.0 & 0.85 \\
\hline $108-663 \mathrm{~A}-4 \mathrm{H}-1,137$ & 25.07 & 88.1 & 2.9 & 9.0 & 0.85 \\
\hline $108-663 \mathrm{~A}-4 \mathrm{H}-2,11$ & 25.31 & 90.3 & 2.6 & 7.1 & 0.85 \\
\hline $108-663 \mathrm{~A}-4 \mathrm{H}-2,19$ & 25.39 & 84.7 & 2.7 & 12.6 & 0.83 \\
\hline $108-663 \mathrm{~A}-4 \mathrm{H}-2,29$ & 25.49 & 88.6 & 2.7 & 8.7 & 0.85 \\
\hline $108-663 \mathrm{~A}-4 \mathrm{H}-2,41$ & 25.61 & 85.8 & 3.4 & 10.9 & 0.80 \\
\hline $108-663 \mathrm{~A}-4 \mathrm{H}-2,50$ & 25.70 & 77.9 & 5.8 & 16.3 & 0.79 \\
\hline $108-663 \mathrm{~A}-4 \mathrm{H}-2,59$ & 25.79 & 70.4 & 7.9 & 21.7 & 0.64 \\
\hline $108-663 \mathrm{~A}-4 \mathrm{H}-2,71$ & 25.91 & 84.4 & 4.2 & 11.4 & 0.79 \\
\hline $108-663 \mathrm{~A}-4 \mathrm{H}-2,79$ & 25.99 & 84.3 & 3.3 & 12.4 & 0.83 \\
\hline $108-663 \mathrm{~A}-4 \mathrm{H}-2,89$ & 26.09 & 84.8 & 4.0 & 11.2 & 0.81 \\
\hline $108-663 \mathrm{~A}-4 \mathrm{H}-2,101$ & 26.21 & 77.0 & 4.1 & 18.9 & 0.81 \\
\hline $108-663 \mathrm{~A}-4 \mathrm{H}-2,110$ & 26.30 & 80.5 & 4.0 & 15.6 & 0.84 \\
\hline
\end{tabular}


Table 5 (continued).

\begin{tabular}{|c|c|c|c|c|c|}
\hline $\begin{array}{l}\text { Core, section, } \\
\text { interval }(\mathrm{cm})\end{array}$ & $\begin{array}{l}\text { Depth } \\
\text { (mbsf) }\end{array}$ & $\begin{array}{c}\mathrm{CaCO}_{3} \\
(\%)\end{array}$ & $\begin{array}{c}\mathrm{SiO}_{2} \\
(\%)\end{array}$ & $\begin{array}{c}\text { Terrigenous } \\
\text { fraction } \\
(\%)\end{array}$ & $\begin{array}{c}\text { Dry-bulk } \\
\text { density } \\
\left(\mathrm{g} / \mathrm{cm}^{3}\right)\end{array}$ \\
\hline $108-663 \mathrm{~A}-4 \mathrm{H}-2,119$ & 26.39 & 80.1 & 4.6 & 15.2 & 0.75 \\
\hline $108-663 \mathrm{~A}-4 \mathrm{H}-2,131$ & 26.51 & 70.7 & 7.7 & 21.6 & 0.65 \\
\hline $108-663 \mathrm{~A}-4 \mathrm{H}-2,139$ & 26.59 & 86.4 & 4.1 & 9.5 & 0.77 \\
\hline $108-663 \mathrm{~A}-4 \mathrm{H}-2,146$ & 26.66 & 81.7 & 4.2 & 14.1 & 0.76 \\
\hline $108-663 \mathrm{~A}-4 \mathrm{H}-3,11$ & 26.81 & 85.5 & 4.8 & 9.7 & 0.90 \\
\hline $108-663 \mathrm{~A}-4 \mathrm{H}-3,19$ & 26.89 & 79.7 & 5.4 & 14.8 & 0.72 \\
\hline $108-663 \mathrm{~A}-4 \mathrm{H}-3,29$ & 26.99 & 87.7 & 4.0 & 8.3 & 0.76 \\
\hline $108-663 \mathrm{~A}-4 \mathrm{H}-3,41$ & 27.11 & 87.8 & 2.6 & 9.5 & 0.77 \\
\hline $108-663 \mathrm{~A}-4 \mathrm{H}-3,50$ & 27.20 & 83.2 & 4.0 & 12.8 & 0.78 \\
\hline $108-663 \mathrm{~A}-4 \mathrm{H}-3,59$ & 27.29 & 70.1 & 9.6 & 20.3 & 0.63 \\
\hline $108-663 \mathrm{~A}-4 \mathrm{H}-3,71$ & 27.41 & 54.7 & 2.4 & 42.9 & 0.55 \\
\hline $108-663 \mathrm{~A}-4 \mathrm{H}-3,79$ & 27.49 & 53.3 & 11.1 & 35.6 & 0.53 \\
\hline $108-663 \mathrm{~A}-4 \mathrm{H}-3,89$ & 27.59 & 82.7 & 5.8 & 11.5 & 0.71 \\
\hline $108-663 \mathrm{~A}-4 \mathrm{H}-3,101$ & 27.71 & 81.9 & 7.3 & 10.8 & 0.69 \\
\hline $108-663 \mathrm{~A}-4 \mathrm{H}-3,110$ & 27.80 & 82.0 & 4.7 & 13.3 & 0.76 \\
\hline $108-663 \mathrm{~A}-4 \mathrm{H}-3,119$ & 27.89 & 78.1 & 6.1 & 15.8 & 0.69 \\
\hline $108-663 \mathrm{~A}-4 \mathrm{H}-3,131$ & 28.01 & 81.7 & 5.4 & 12.9 & 0.73 \\
\hline $108-663 \mathrm{~A}-4 \mathrm{H}-3,139$ & 28.09 & 84.0 & 4.4 & 11.6 & 0.77 \\
\hline $108-663 \mathrm{~A}-4 \mathrm{H}-3,146$ & 28.16 & 83.3 & 4.5 & 12.2 & 0.77 \\
\hline $108-663 \mathrm{~A}-4 \mathrm{H}-4,11$ & 28.31 & 79.5 & 6.1 & 14.4 & 0.72 \\
\hline 108- $663 \mathrm{~A}-4 \mathrm{H}-4,19$ & 28.39 & 84.4 & 4.1 & 11.5 & 0.78 \\
\hline $108-663 \mathrm{~A}-4 \mathrm{H}-4,41$ & 28.61 & 87.1 & 3.5 & 9.4 & 0.82 \\
\hline $108-663 \mathrm{~A}-4 \mathrm{H}-4,50$ & 28.70 & 70.7 & 4.3 & 24.9 & 0.80 \\
\hline $108-663 \mathrm{~A}-4 \mathrm{H}-4,59$ & 28.79 & 87.2 & 4.4 & 8.4 & 0.80 \\
\hline $108-663 \mathrm{~A}-4 \mathrm{H}-4,79$ & 28.99 & 77.7 & 5.2 & 17.1 & 0.71 \\
\hline $108-663 \mathrm{~A}-4 \mathrm{H}-4,89$ & 29.09 & 57.1 & 6.3 & 36.6 & 0.59 \\
\hline $108-663 \mathrm{~A}-4 \mathrm{H}-4,101$ & 29.21 & 86.0 & 3.9 & 10.1 & 0.74 \\
\hline $108-663 \mathrm{~A}-4 \mathrm{H}-4,110$ & 29.30 & 86.7 & 3.9 & 9.5 & 0.83 \\
\hline $108-663 \mathrm{~A}-4 \mathrm{H}-4,119$ & 29.39 & 84.4 & 3.9 & 11.7 & 0.82 \\
\hline $108-663 \mathrm{~A}-4 \mathrm{H}-4,131$ & 29.51 & 75.1 & 6.8 & 18.1 & 0.73 \\
\hline $108-663 \mathrm{~A}-4 \mathrm{H}-4,139$ & 29.59 & 82.2 & 4.3 & 13.6 & 0.80 \\
\hline $108-663 \mathrm{~A}-4 \mathrm{H}-4,146$ & 29.66 & 85.7 & 4.3 & 10.0 & 0.86 \\
\hline $108-663 \mathrm{~A}-4 \mathrm{H}-5,11$ & 29.81 & 84.4 & 3.4 & 12.3 & 0.80 \\
\hline $108-663 \mathrm{~A}-4 \mathrm{H}-5,19$ & 29.89 & 81.9 & 3.7 & 14.5 & 0.81 \\
\hline $108-663 \mathrm{~A}-4 \mathrm{H}-5,29$ & 29.99 & 65.7 & 5.9 & 28.4 & 0.65 \\
\hline $108-663 \mathrm{~A}-4 \mathrm{H}-5,41$ & 30.11 & 69.8 & 5.5 & 24.8 & 0.68 \\
\hline $108-663 \mathrm{~A}-4 \mathrm{H}-5,50$ & 30.20 & 69.5 & 8.8 & 21.7 & 0.66 \\
\hline $108-663 \mathrm{~A}-4 \mathrm{H}-5,59$ & 30.29 & 77.4 & 6.5 & 16.1 & 0.77 \\
\hline $108-663 \mathrm{~A}-4 \mathrm{H}-5,79$ & 30.49 & 81.7 & 2.2 & 16.1 & 0.74 \\
\hline $108-663 \mathrm{~A}-4 \mathrm{H}-5,89$ & 30.59 & 79.3 & 5.3 & 15.4 & 0.77 \\
\hline $108-663 \mathrm{~A}-4 \mathrm{H}-5,101$ & 30.71 & 79.4 & 5.8 & 14.8 & 0.69 \\
\hline $108-663 \mathrm{~A}-4 \mathrm{H}-5,110$ & 30.80 & 67.1 & 8.0 & 24.9 & 0.66 \\
\hline $108-663 \mathrm{~A}-4 \mathrm{H}-5,119$ & 30.89 & 63.3 & 9.6 & 27.1 & 0.60 \\
\hline $108-663 \mathrm{~A}-4 \mathrm{H}-5,131$ & 31.01 & 69.8 & 8.1 & 22.1 & 0.65 \\
\hline $108-663 \mathrm{~A}-4 \mathrm{H}-5,139$ & 31.09 & 78.2 & 6.3 & 15.5 & 0.68 \\
\hline $108-663 \mathrm{~A}-4 \mathrm{H}-5,146$ & 31.16 & 80.9 & 5.3 & 13.8 & 0.72 \\
\hline $108-663 \mathrm{~A}-4 \mathrm{H}-6,11$ & 31.31 & 85.0 & 4.2 & 10.8 & 0.73 \\
\hline $108-663$ A- 4 H- 6,19 & 31.39 & 82.9 & 4.2 & 12.9 & 0.72 \\
\hline $108-663 \mathrm{~A}-4 \mathrm{H}-6,29$ & 31.49 & 83.7 & 4.3 & 12.0 & 0.76 \\
\hline $108-663 \mathrm{~A}-4 \mathrm{H}-6,41$ & 31.61 & 85.8 & 3.8 & 10.4 & 0.74 \\
\hline $108-663 \mathrm{~A}-4 \mathrm{H}-6,50$ & 31.70 & 79.4 & 4.8 & 15.8 & 0.75 \\
\hline $108-663 \mathrm{~A}-4 \mathrm{H}-6,59$ & 31.79 & 67.7 & 8.0 & 24.3 & 0.68 \\
\hline $108-663 \mathrm{~A}-4 \mathrm{H}-6,71$ & 31.91 & 80.5 & 6.8 & 12.7 & 0.70 \\
\hline $108-663 \mathrm{~A}-4 \mathrm{H}-6,79$ & 31.99 & 76.9 & 6.1 & 17.0 & 0.71 \\
\hline
\end{tabular}

Table 6 . Percentages of carbonate, opal, and terrigenous fraction, and dry-bulk densities at Hole 664B.

\begin{tabular}{lccccc}
\hline Core, section, & $\begin{array}{c}\text { Depth } \\
\text { interval }(\mathrm{cm})\end{array}$ & $\begin{array}{c}\mathrm{CaCO}_{3} \\
(\%)\end{array}$ & $\begin{array}{c}\mathrm{SiO}_{2} \\
(\%)\end{array}$ & $\begin{array}{c}\text { Terrigenous } \\
\text { fraction } \\
(\%)\end{array}$ & $\begin{array}{c}\text { Dry-bulk } \\
\text { density } \\
\left(\mathrm{g} / \mathrm{cm}^{3}\right)\end{array}$ \\
\hline 108-664B-1H-1, 11 & 0.11 & 88.0 & 1.5 & 10.6 & 0.93 \\
$108-664 \mathrm{~B}-1 \mathrm{H}-1,19$ & 0.19 & 69.0 & 4.2 & 26.9 & \\
$108-664 \mathrm{~B}-1 \mathrm{H}-1,29$ & 0.29 & 70.4 & 3.8 & 25.7 & 0.69 \\
$108-664 \mathrm{~B}-1 \mathrm{H}-1,41$ & 0.41 & 66.0 & 2.7 & 31.2 & 0.60 \\
$108-664 \mathrm{~B}-1 \mathrm{H}-1,59$ & 0.59 & 82.7 & 2.1 & 15.2 & 0.70 \\
$108-664 \mathrm{~B}-1 \mathrm{H}-1,71$ & 0.71 & 85.2 & 1.9 & 12.9 & 0.76 \\
$108-664 \mathrm{~B}-1 \mathrm{H}-1,79$ & 0.79 & 78.5 & 2.2 & 19.3 & 0.76 \\
108-664B-1H-1, 89 & 0.89 & 69.3 & 2.6 & 28.1 & 0.69 \\
108-664B-1H-1, 101 & 1.01 & 82.2 & 2.1 & 15.7 & 0.71 \\
108-664B-1H-1, 119 & 1.19 & 72.6 & 2.6 & 24.8 & 0.75 \\
$108-664 \mathrm{~B}-1 \mathrm{H}-1,126$ & 1.26 & 74.5 & 2.5 & 23.0 & 0.79 \\
108-664B-1H-1, 139 & 1.39 & 85.7 & 1.6 & 12.7 & 0.80
\end{tabular}

Table 6 (continued).

\begin{tabular}{|c|c|c|c|c|c|}
\hline $\begin{array}{l}\text { Core, section, } \\
\text { interval }(\mathrm{cm})\end{array}$ & $\begin{array}{l}\text { Depth } \\
\text { (mbsf) }\end{array}$ & $\begin{array}{c}\mathrm{CaCO}_{3} \\
(\%)\end{array}$ & $\begin{array}{l}\mathrm{SiO}_{2} \\
(\%)\end{array}$ & $\begin{array}{l}\text { Terrigenous } \\
\text { fraction } \\
(\%)\end{array}$ & $\begin{array}{c}\text { Dry-bulk } \\
\text { density } \\
\left(\mathrm{g} / \mathrm{cm}^{3}\right)\end{array}$ \\
\hline 108-664B-1H-2, 11 & 1.61 & 80.7 & 2.0 & 17.3 & 0.77 \\
\hline 108-664B-1H-2, 19 & 1.69 & 74.0 & 2.5 & 23.5 & 0.78 \\
\hline $108-664 \mathrm{~B}-1 \mathrm{H}-2,29$ & 1.79 & 62.8 & 2.8 & 34.4 & 0.69 \\
\hline $108-664 \mathrm{~B}-1 \mathrm{H}-2,41$ & 1.91 & 72.1 & 4.0 & 23.9 & 0.69 \\
\hline $108-664 \mathrm{~B}-1 \mathrm{H}-2,59$ & 2.09 & 67.5 & 4.0 & 28.5 & 0.68 \\
\hline 108-664B-1H-2, 71 & 2.21 & 67.5 & 2.7 & 29.8 & 0.62 \\
\hline $108-664 \mathrm{~B}-1 \mathrm{H}-2,79$ & 2.29 & 75.3 & 1.7 & 23.0 & 0.67 \\
\hline $108-664 \mathrm{~B}-1 \mathrm{H}-2,89$ & 2.39 & 73.6 & 2.8 & 23.6 & 0.65 \\
\hline 108-664B-1H-2, 101 & 2.51 & 86.1 & 1.5 & 12.4 & 0.76 \\
\hline 108-664B-1H-2, 119 & 2.69 & 68.0 & 2.5 & 29.5 & 0.79 \\
\hline 108-664B-1H-2, 126 & 2.76 & 80.0 & 1.4 & 18.6 & 0.81 \\
\hline 108-664B-1H-2, 139 & 2.89 & 85.1 & 1.7 & 13.3 & 0.82 \\
\hline 108-664B-1H-2, 146 & 2.96 & 83.5 & 1.9 & 14.6 & 0.72 \\
\hline $108-664 \mathrm{~B}-1 \mathrm{H}-3,11$ & 3.11 & 84.0 & 1.3 & 14.7 & 0.87 \\
\hline 108-664B-1H-3, 19 & 3.19 & 85.9 & 1.7 & 12.3 & 0.86 \\
\hline 108-664B-1H-3, 29 & 3.29 & 80.6 & 1.6 & 17.8 & 0.80 \\
\hline $108-664 \mathrm{~B}-1 \mathrm{H}-3,41$ & 3.41 & 74.0 & 1.8 & 24.2 & 0.83 \\
\hline $108-664 \mathrm{~B}-1 \mathrm{H}-3,59$ & 3.59 & 81.6 & 1.9 & 16.6 & 0.74 \\
\hline $108-664 \mathrm{~B}-1 \mathrm{H}-3,71$ & 3.71 & 81.8 & 1.7 & 16.5 & 0.83 \\
\hline $108-664 \mathrm{~B}-1 \mathrm{H}-3,79$ & 3.79 & 77.0 & 1.4 & 21.6 & 0.71 \\
\hline 108-664B-1H-3, 89 & 3.89 & 72.1 & 2.0 & 26.0 & 0.82 \\
\hline 108-664B-1H-3, 101 & 4.01 & & 3.7 & & 0.81 \\
\hline 108-664B-1H-3, 119 & 4.19 & 75.7 & 2.5 & 21.9 & 0.67 \\
\hline 108-664B-1H-3, 126 & 4.26 & 75.9 & 2.6 & 21.4 & 0.66 \\
\hline 108-664B-1H-3, 139 & 4.39 & 74.9 & 3.3 & 21.9 & 0.67 \\
\hline 108-664B-1H-3, 146 & 4.46 & 80.2 & 2.9 & 16.9 & 0.65 \\
\hline 108-664B-1H-4, 11 & 4.61 & 76.2 & 3.3 & 20.5 & 0.72 \\
\hline $108-664 \mathrm{~B}-1 \mathrm{H}-4,19$ & 4.69 & 76.0 & 2.7 & 21.3 & 0.69 \\
\hline $108-664 \mathrm{~B}-1 \mathrm{H}-4,29$ & 4.79 & & 3.2 & & 0.68 \\
\hline $108-664 \mathrm{~B}-1 \mathrm{H}-4,41$ & 4.91 & & 3.3 & & 0.67 \\
\hline $108-664 \mathrm{~B}-1 \mathrm{H}-4,59$ & 5.09 & 76.3 & 3.2 & 20.6 & 0.68 \\
\hline 108-664B-1H-4, 71 & 5.21 & 65.5 & 2.5 & 32.0 & 0.62 \\
\hline $108-664 \mathrm{~B}-1 \mathrm{H}-4,79$ & 5.29 & 62.5 & 2.9 & 34.7 & 0.55 \\
\hline 108-664B-1H-4, 89 & 5.39 & 72.7 & 3.6 & 23.7 & \\
\hline 108-664B-1H-4, 101 & 5.51 & 82.6 & 1.7 & 15.7 & 0.83 \\
\hline 108-664B-1H-4, 119 & 5.69 & 79.6 & 2.0 & 18.4 & 0.78 \\
\hline $108-664 \mathrm{~B}-1 \mathrm{H}-4,126$ & 5.76 & 80.8 & 1.9 & 17.3 & 0.79 \\
\hline $108-664 \mathrm{~B}-1 \mathrm{H}-4,139$ & 5.89 & 74.6 & 2.9 & 22.5 & 0.72 \\
\hline $108-664 \mathrm{~B}-1 \mathrm{H}-4,146$ & 5.96 & 64.9 & 2.2 & 33.0 & 0.83 \\
\hline $108-664 \mathrm{~B}-1 \mathrm{H}-5,11$ & 6.11 & 75.2 & 1.5 & 23.2 & 0.71 \\
\hline $108-664 \mathrm{~B}-1 \mathrm{H}-5,19$ & 6.19 & 74.0 & 2.8 & 23.2 & 0.67 \\
\hline 108-664B-1H-5, 29 & 6.29 & 73.9 & 2.2 & 24.0 & 0.77 \\
\hline 108-664B-1H-5, 41 & 6.41 & 53.1 & 1.3 & 45.7 & 0.72 \\
\hline $108-664 \mathrm{~B}-1 \mathrm{H}-5,59$ & 6.59 & 89.7 & 2.5 & 7.8 & 0.86 \\
\hline 108-664B-1H-5, 71 & 6.71 & 79.7 & 2.0 & 18.3 & 0.83 \\
\hline 108-664B-1H-5, 79 & 6.79 & 72.6 & 2.5 & 24.9 & 0.76 \\
\hline 108-664B-1H-5, 89 & 6.89 & 84.8 & 2.3 & 13.0 & 0.84 \\
\hline 108-664B-1H-5, 101 & 7.01 & 83.7 & 2.1 & 14.1 & 0.85 \\
\hline 108-664B-1H-5, 119 & 7.19 & 85.1 & 1.9 & 13.1 & 0.91 \\
\hline $108-664 \mathrm{~B}-1 \mathrm{H}-5,126$ & 7.26 & 77.9 & 1.9 & 20.2 & 0.82 \\
\hline 108-664B-1H-5, 139 & 7.39 & 75.2 & 2.1 & 22.7 & 0.72 \\
\hline 108-664B-1H-6, 11 & 7.61 & 66.4 & 3.0 & 30.7 & 0.75 \\
\hline 108-664B-1H-6, 19 & 7.69 & 75.0 & 2.2 & 22.8 & 0.71 \\
\hline $108-664 \mathrm{~B}-1 \mathrm{H}-6,29$ & 7.79 & 85.4 & 1.8 & 12.8 & 0.79 \\
\hline 108-664B-1H-6, 41 & 7.91 & 86.7 & 1.4 & 11.8 & 0.82 \\
\hline 108-664B-1H-6, 59 & 8.09 & 80.4 & 2.0 & 17.5 & 0.82 \\
\hline 108-664B-1H-6, 71 & 8.21 & 66.9 & 2.2 & 30.9 & 0.77 \\
\hline 108-664B-1H-6, 79 & 8.29 & 80.1 & 1.5 & 18.4 & 0.77 \\
\hline 108-664B-1H-6, 89 & 8.39 & 74.0 & 3.1 & 22.9 & 0.76 \\
\hline 108-664B-1H-6, 101 & 8.51 & 80.0 & 1.4 & 18.6 & 0.76 \\
\hline 108-664B-1H-6, 119 & 8.69 & 86.0 & 2.0 & 12.0 & 0.84 \\
\hline 108-664B-1H-6, 126 & 8.76 & 82.1 & 1.8 & 16.1 & 0.81 \\
\hline 108-664B-1H-6, 139 & 8.89 & 79.1 & 2.0 & 18.9 & 0.75 \\
\hline 108-664B-1H-6, 146 & 8.96 & 73.5 & 2.1 & 24.4 & 0.79 \\
\hline 108-664B-1H-7, 11 & 9.11 & 63.5 & 2.0 & 34.5 & 0.75 \\
\hline 108-664B-1H-7, 19 & 9.19 & 75.1 & 3.2 & 21.7 & 0.69 \\
\hline 108-664B-1H-7, 29 & 9.29 & 71.7 & 3.0 & 25.4 & 0.66 \\
\hline 108-664B-1H-7, 41 & 9.41 & 69.8 & 3.5 & 26.7 & 0.70 \\
\hline 108-664B-2H-1, 11 & 9.61 & 69.6 & 3.1 & 27.2 & 0.63 \\
\hline 108-664B-2H-1, 19 & 9.69 & & 0.8 & & 0.76 \\
\hline 108-664B-2H-1, 29 & 9.79 & 83.1 & 1.1 & 15.9 & 0.86 \\
\hline $108-664 \mathrm{~B}-2 \mathrm{H}-1,41$ & 9.91 & 78.0 & 1.5 & 20.5 & 0.88 \\
\hline 108-664B-2H-1, 59 & 10.09 & 84.8 & 1.9 & 13.3 & 0.98 \\
\hline 108-664B-2H-1, 71 & 10.21 & 66.2 & 1.3 & 32.5 & 0.91 \\
\hline 108-664B-2H-1, 79 & 10.29 & 88.6 & 1.3 & 10.0 & 0.90 \\
\hline 108-664B-2H-1, 89 & 10.39 & 83.6 & 1.7 & 14.7 & 0.90 \\
\hline $108-664 \mathrm{~B}-2 \mathrm{H}-1,101$ & 10.51 & 64.8 & 2.7 & 32.5 & 0.72 \\
\hline
\end{tabular}


Table 6 (continued).

\begin{tabular}{|c|c|c|c|c|c|}
\hline $\begin{array}{l}\text { Core, section, } \\
\text { interval }(\mathrm{cm})\end{array}$ & $\begin{array}{l}\text { Depth } \\
\text { (mbsf) }\end{array}$ & $\begin{array}{c}\mathrm{CaCO}_{3} \\
(\%)\end{array}$ & $\begin{array}{l}\mathrm{SiO}_{2} \\
(\%)\end{array}$ & $\begin{array}{c}\text { Terrigenous } \\
\text { fraction } \\
(\%)\end{array}$ & $\begin{array}{c}\text { Dry-bulk } \\
\text { density } \\
\left(\mathrm{g} / \mathrm{cm}^{3}\right)\end{array}$ \\
\hline 108-664B-2H-1, 119 & 10.69 & 53.2 & 2.7 & 44.1 & \\
\hline $108-664 \mathrm{~B}-2 \mathrm{H}-1,126$ & 10.76 & 56.2 & 2.5 & 41.3 & 0.63 \\
\hline 108-664B-2H-1, 139 & 10.89 & 73.6 & 3.0 & 23.4 & 0.70 \\
\hline $108-664 \mathrm{~B}-2 \mathrm{H}-1,146$ & 10.96 & 76.9 & 2.1 & 20.9 & 0.73 \\
\hline 108-664B-2H-2, 11 & 11.11 & 82.9 & 2.0 & 15.1 & 0.79 \\
\hline 108-664B-2H-2, 19 & 11.19 & 83.1 & 1.8 & 15.1 & 0.81 \\
\hline 108-664B-2H-2, 29 & 11.29 & 79.8 & 1.2 & 19.0 & 0.80 \\
\hline 108-664B-2H-2, 41 & 11.41 & 77.7 & 2.3 & 20.0 & 0.79 \\
\hline 108-664B-2H-2, 59 & 11.59 & 79.4 & 1.4 & 19.2 & 0.81 \\
\hline $108-664 \mathrm{~B}-2 \mathrm{H}-2,71$ & 11.71 & 80.9 & 0.6 & 18.5 & 0.83 \\
\hline 108-664B-2H-2, 79 & 11.79 & 78.0 & 2.1 & 19.9 & 0.73 \\
\hline 108-664B-2H-2, 89 & 11.89 & 79.8 & 2.2 & 18.1 & 0.80 \\
\hline 108-664B-2H-2, 101 & 12.01 & 70.1 & 1.3 & 28.6 & 0.90 \\
\hline 108-664B-2H-2, 119 & 12.19 & 79.6 & 1.3 & 19.1 & 0.87 \\
\hline 108-664B-2H-2, 126 & 12.26 & 79.5 & 1.2 & 19.3 & 0.92 \\
\hline 108-664B-2H-2, 139 & 12.39 & 87.4 & 1.0 & 11.7 & 0.93 \\
\hline 108-664B-2H-2, 146 & 12.46 & 78.5 & 1.2 & 20.3 & 0.92 \\
\hline $108-664 \mathrm{~B}-2 \mathrm{H}-3,11$ & 12.61 & 87.4 & 0.8 & 11.8 & 0.98 \\
\hline 108-664B-2H-3, 19 & 12.69 & 83.0 & 0.7 & 16.2 & 0.97 \\
\hline $108-664 \mathrm{~B}-2 \mathrm{H}-3,29$ & 12.79 & 86.7 & 0.8 & 12.5 & 0.93 \\
\hline 108-664B-2H-3, 41 & 12.91 & 74.4 & 1.2 & 24.4 & 0.95 \\
\hline 108-664B-2H-3, 59 & 13.09 & 65.7 & 1.5 & 32.8 & 0.83 \\
\hline 108-664B-2H-3, 71 & 13.21 & 85.3 & 1.3 & 13.4 & 0.87 \\
\hline 108-664B-2H-3, 79 & 13.29 & 90.0 & 1.1 & 8.9 & 0.94 \\
\hline 108-664B-2H-3, 89 & 13.39 & 93.0 & 0.9 & 6.1 & 0.96 \\
\hline 108-664B-2H-3, 101 & 13.51 & 91.9 & 0.9 & 7.1 & 1.07 \\
\hline 108-664B-2H-3, 119 & 13.69 & 90.9 & 0.9 & 8.2 & 0.96 \\
\hline $108-664 \mathrm{~B}-2 \mathrm{H}-3,126$ & 13.76 & 89.7 & 0.6 & 9.7 & 1.10 \\
\hline $108-664 \mathrm{~B}-2 \mathrm{H}-3,139$ & 13.89 & 86.8 & 0.9 & 12.3 & 0.87 \\
\hline 108-664B-2H-3, 146 & 13.96 & 79.7 & 1.5 & 18.8 & 0.90 \\
\hline $108-664 \mathrm{~B}-2 \mathrm{H}-4,11$ & 14.11 & 51.3 & 2.4 & 46.2 & 0.72 \\
\hline 108-664B-2H-4, 19 & 14.19 & 54.1 & 2.1 & 43.7 & 0.63 \\
\hline 108-664B-2H-4, 29 & 14.29 & 65.4 & 2.4 & 32.2 & 0.75 \\
\hline 108-664B-2H-4, 41 & 14.41 & 80.6 & 2.3 & 17.0 & 0.76 \\
\hline $108-664 \mathrm{~B}-2 \mathrm{H}-4,59$ & 14.59 & 71.0 & 1.7 & 27.3 & 0.72 \\
\hline 108-664B-2H-4, 71 & 14.71 & 82.3 & 1.7 & 16.0 & 0.80 \\
\hline 108-664B-2H-4, 79 & 14.79 & 84.2 & 2.3 & 13.5 & 0.77 \\
\hline 108-664B-2H-4, 89 & 14.89 & 86.2 & 1.4 & 12.4 & 0.90 \\
\hline 108-664B-2H-4, 101 & 15.01 & 88.5 & 1.0 & 10.4 & 0.90 \\
\hline 108-664B-2H-4, 119 & 15.19 & 78.3 & 1.5 & 20.2 & 0.82 \\
\hline 108-664B-2H-4, 126 & 15.26 & 64.1 & 2.0 & 33.8 & 0.71 \\
\hline 108-664B-2H-4, 139 & 15.39 & 82.9 & 2.0 & 15.1 & 0.79 \\
\hline 108-664B-2H-4, 146 & 15.46 & 80.4 & 1.6 & 18.0 & 0.83 \\
\hline 108-664B-2H-5, 11 & 15.61 & 76.2 & 1.7 & 22.1 & 0.82 \\
\hline 108-664B-2H-5, 19 & 15.69 & 85.5 & 1.5 & 13.1 & 0.83 \\
\hline 108-664B-2H-5, 29 & 15.79 & 82.7 & 1.7 & 15.7 & 0.86 \\
\hline 108-664B-2H-5, 41 & 15.91 & 78.2 & 2.3 & 19.5 & 0.80 \\
\hline $108-664 \mathrm{~B}-2 \mathrm{H}-5,59$ & 16.09 & 74.0 & 1.8 & 24.3 & 0.81 \\
\hline 108-664B-2H-5, 71 & 16.21 & 60.4 & 1.9 & 37.7 & 0.85 \\
\hline 108-664B-2H-5, 79 & 16.29 & 88.7 & 1.0 & 10.3 & 0.91 \\
\hline 108-664B-2H-5, 89 & 16.39 & 78.1 & 1.5 & 20.4 & 0.91 \\
\hline 108-664B-2H-5, 101 & 16.51 & 90.2 & 1.2 & 8.6 & 0.97 \\
\hline 108-664B-2H-5, 119 & 16.69 & 86.1 & 1.0 & 12.9 & 0.95 \\
\hline 108-664B-2H-6, 11 & 17.11 & 86.9 & 0.9 & 12.2 & 0.98 \\
\hline 108-664B-2H-6, 19 & 17.19 & 85.6 & 1.0 & 13.4 & 0.93 \\
\hline 108-664B-2H-6, 29 & 17.29 & 87.8 & 0.9 & 11.3 & 1.02 \\
\hline 108-664B-2H-6, 41 & 17.41 & 88.9 & 1.1 & 10.0 & 0.98 \\
\hline 108-664B-2H-6, 59 & 17.59 & 84.2 & 0.7 & 15.0 & 0.94 \\
\hline 108-664B-2H-6, 71 & 17.71 & 86.7 & 0.8 & 12.5 & 1.01 \\
\hline 108-664B-2H-6, 79 & 17.79 & 90.1 & 1.0 & 8.9 & 0.99 \\
\hline 108-664B-2H-6, 89 & 17.89 & 87.2 & 1.1 & 11.7 & 1.03 \\
\hline 108-664B-2H-6, 101 & 18.01 & 89.7 & 0.9 & 9.4 & 1.04 \\
\hline 108-664B-2H-6, 119 & 18.19 & 78.0 & 1.1 & 20.9 & 0.88 \\
\hline 108-664B-2H-6, 126 & 18.26 & 85.5 & 1.5 & 13.0 & 0.91 \\
\hline 108-664B-2H-6, 139 & 18.39 & 90.1 & 1.2 & 8.7 & 0.90 \\
\hline 108-664B-2H-6, 146 & 18.46 & 80.4 & 1.0 & 18.6 & 0.92 \\
\hline 108-664B-3H-1, 11 & 19.11 & 82.5 & 1.1 & 16.4 & 0.88 \\
\hline 108-664B-3H-1, 19 & 19.19 & 75.8 & 1.4 & 22.8 & 0.73 \\
\hline 108-664B-3H-1, 29 & 19.29 & 87.2 & 1.7 & 11.1 & 0.96 \\
\hline 108-664B-3H-1, 41 & 19,41 & 86.3 & 1.1 & 12.6 & 0.97 \\
\hline 108-664B-3H-1, 59 & 19.59 & 76.8 & 1.3 & 21.9 & 0.89 \\
\hline 108-664B-3H-1, 71 & 19.71 & 78.1 & 1.7 & 20.3 & 0.86 \\
\hline 108-664B-3H-1, 79 & 19.79 & 83.4 & 1.2 & 15.4 & 0.92 \\
\hline 108-664B-3H-1, 89 & 19.89 & 70.8 & 1.6 & 27.6 & 0.88 \\
\hline 108-664B-3H-1, 101 & 20.01 & 84.5 & 0.8 & 14.8 & 0.90 \\
\hline 108-664B-3H-1, 119 & 20.19 & 85.2 & 1.1 & 13.7 & 0.93 \\
\hline 108-664B-3H-1, 126 & 20.26 & 86.6 & 1.2 & 12.2 & 0.94 \\
\hline
\end{tabular}

Table 6 (continued).

\begin{tabular}{|c|c|c|c|c|c|}
\hline $\begin{array}{l}\text { Core, section, } \\
\text { interval }(\mathrm{cm})\end{array}$ & $\begin{array}{l}\text { Depth } \\
\text { (mbsf) }\end{array}$ & $\begin{array}{c}\mathrm{CaCO}_{3} \\
(\%)\end{array}$ & $\begin{array}{c}\mathrm{SiO}_{2} \\
(\%)\end{array}$ & $\begin{array}{l}\text { Terrigenous } \\
\text { fraction } \\
(\%)\end{array}$ & $\begin{array}{c}\text { Dry-bulk } \\
\text { density } \\
\left(\mathrm{g} / \mathrm{cm}^{3}\right)\end{array}$ \\
\hline $108-664 \mathrm{~B}-3 \mathrm{H}-1,139$ & 20.39 & 85.3 & 1.6 & 13.2 & 0.87 \\
\hline $108-664 \mathrm{~B}-3 \mathrm{H}-1,145$ & 20.45 & 84.0 & 1.4 & 14.6 & 0.94 \\
\hline $108-664 \mathrm{~B}-3 \mathrm{H}-2,11$ & 20.61 & 82.9 & 1.8 & 15.4 & 0.96 \\
\hline $108-664 \mathrm{~B}-3 \mathrm{H}-2,19$ & 20.69 & 71.8 & 1.8 & 26.4 & 0.72 \\
\hline $108-664 \mathrm{~B}-3 \mathrm{H}-2,29$ & 20.79 & 60.6 & 2.1 & 37.2 & 0.77 \\
\hline $108-664 \mathrm{~B}-3 \mathrm{H}-2,41$ & 20.91 & 64.6 & 1.9 & 33.5 & 0.69 \\
\hline $108-664 \mathrm{~B}-3 \mathrm{H}-2,59$ & 21.09 & 79.2 & 1.5 & 19.3 & 0.85 \\
\hline 108-664B-3H-2, 71 & 21.21 & 69.9 & 1.7 & 28.4 & 0.79 \\
\hline 108-664B-3H-2, 79 & 21.29 & 82.3 & 1.7 & 16.0 & 0.82 \\
\hline 108-664B-3H-2, 89 & 21.39 & 79.4 & 1.9 & 18.8 & 0.84 \\
\hline 108-664B-3H-2, 101 & 21.51 & 85.7 & 1.3 & 13.0 & 0.96 \\
\hline $108-664 \mathrm{~B}-3 \mathrm{H}-2,119$ & 21.69 & 82.9 & 2.2 & 14.9 & 0.91 \\
\hline 108-664B-3H-2, 126 & 21.76 & 81.7 & 1.3 & 16.9 & 0.94 \\
\hline $108-664 \mathrm{~B}-3 \mathrm{H}-2,139$ & 21.89 & 78.8 & 2.2 & 19.1 & 0.79 \\
\hline $108-664 \mathrm{~B}-3 \mathrm{H}-2,146$ & 21.96 & 78.9 & 2.1 & 19.0 & 0.81 \\
\hline $108-664 \mathrm{~B}-3 \mathrm{H}-3,11$ & 22.11 & 72.3 & 2.4 & 25.3 & 0.78 \\
\hline $108-664 \mathrm{~B}-3 \mathrm{H}-3,19$ & 22.19 & 61.1 & 2.8 & 36.1 & 0.69 \\
\hline $108-664 \mathrm{~B}-3 \mathrm{H}-3,29$ & 22.29 & 67.3 & 1.9 & 30.8 & 0.83 \\
\hline $108-664 \mathrm{~B}-3 \mathrm{H}-3,41$ & 22.41 & 82.6 & 1.8 & 15.6 & 0.87 \\
\hline $108-664 \mathrm{~B}-3 \mathrm{H}-3,59$ & 22.59 & 81.1 & 2.6 & 16.3 & 0.86 \\
\hline $108-664 \mathrm{~B}-3 \mathrm{H}-3,71$ & 22.71 & 85.8 & 1.8 & 12.4 & 0.90 \\
\hline 108-664B-3H-3, 79 & 22.79 & 80.9 & 2.1 & 17.0 & 0.81 \\
\hline $108-664 \mathrm{~B}-3 \mathrm{H}-3,89$ & 22.89 & 66.0 & 3.0 & 31.0 & 0.76 \\
\hline 108-664B-3H-3, 101 & 23.01 & 62.2 & 2.3 & 35.4 & 0.74 \\
\hline $108-664 \mathrm{~B}-3 \mathrm{H}-3,119$ & 23.19 & 87.1 & 1.7 & 11.2 & 0.91 \\
\hline 108-664B-3H-3, 126 & 23.26 & 91.0 & 1.8 & 7.2 & 0.92 \\
\hline $108-664 \mathrm{~B}-3 \mathrm{H}-3,139$ & 23.39 & 87.6 & 1.1 & 11.3 & 0.88 \\
\hline $108-664 \mathrm{~B}-3 \mathrm{H}-3,146$ & 23.46 & 88.1 & 1.1 & 10.8 & 0.95 \\
\hline $108-664 \mathrm{~B}-3 \mathrm{H}-4,11$ & 23.61 & 86.5 & 1.3 & 12.3 & 0.93 \\
\hline 108-664B-3H-4, 19 & 23.69 & 85.9 & 1.6 & 12.5 & 0.86 \\
\hline 108-664B-3H-4, 29 & 23.79 & 87.3 & 1.4 & 11.3 & 0.92 \\
\hline $108-664 \mathrm{~B}-3 \mathrm{H}-4,41$ & 23.91 & 84.2 & 1.5 & 14.4 & 0.89 \\
\hline $108-664 \mathrm{~B}-3 \mathrm{H}-4,59$ & 24.09 & 53.4 & 2.4 & 44.2 & 0.74 \\
\hline $108-664 \mathrm{~B}-3 \mathrm{H}-4,71$ & 24.21 & 58.6 & 2.9 & 38.5 & 0.70 \\
\hline $108-664 \mathrm{~B}-3 \mathrm{H}-4,79$ & 24.29 & 67.6 & 1.9 & 30.5 & 0.72 \\
\hline 108-664B-3H-4, 89 & 24.39 & 81.8 & 1.7 & 16.6 & 0.85 \\
\hline 108-664B-3H-4, 101 & 24.51 & 81.0 & 2.1 & 16.9 & 0.89 \\
\hline $108-664 \mathrm{~B}-3 \mathrm{H}-4,129$ & 24.79 & 87.7 & 1.5 & 10.8 & 0.95 \\
\hline $108-664 \mathrm{~B}-3 \mathrm{H}-4,134$ & 24.84 & 88.5 & 1.6 & 10.0 & 0.97 \\
\hline $108-664 \mathrm{~B}-3 \mathrm{H}-4,139$ & 24.89 & 87.6 & 1.3 & 11.1 & 0.94 \\
\hline $108-664 \mathrm{~B}-3 \mathrm{H}-4,146$ & 24.96 & 89.2 & 1.3 & 9.5 & 0.99 \\
\hline 108-664B-3H-5, 11 & 25.11 & 86.9 & 1.4 & 11.7 & 0.98 \\
\hline $108-664 \mathrm{~B}-3 \mathrm{H}-5,19$ & 25.19 & 87.3 & 1.3 & 11.4 & 0.89 \\
\hline 108-664B-3H-5, 29 & 25.29 & 86.7 & 1.5 & 11.8 & 0.93 \\
\hline $108-664 \mathrm{~B}-3 \mathrm{H}-5,41$ & 25.41 & 81.6 & 1.9 & 16.5 & 0.94 \\
\hline $108-664 \mathrm{~B}-3 \mathrm{H}-5,59$ & 25.59 & 61.9 & 2.6 & 35.5 & 0.77 \\
\hline $108-664 \mathrm{~B}-3 \mathrm{H}-5,71$ & 25.71 & 84.7 & 1.4 & 13.9 & 0.86 \\
\hline $108-664 \mathrm{~B}-3 \mathrm{H}-5,79$ & 25.79 & 83.8 & 1.4 & 14.9 & 0.85 \\
\hline $108-664$ B-3H-5, 89 & 25.89 & 85.7 & 1.9 & 12.5 & 0.94 \\
\hline $108-664 \mathrm{~B}-3 \mathrm{H}-5,101$ & 26.01 & 84.1 & 2.1 & 13.9 & 0.93 \\
\hline 108-664B-3H-5, 119 & 26.19 & 78.1 & 2.2 & 19.7 & 0.84 \\
\hline 108-664B-3H-5, 126 & 26.26 & 82.3 & 1.9 & 15.9 & 0.84 \\
\hline $108-664 \mathrm{~B}-3 \mathrm{H}-5,139$ & 26.39 & 73.0 & 2.6 & 24.5 & 0.72 \\
\hline $108-664 \mathrm{~B}-3 \mathrm{H}-5,146$ & 26.46 & 83.3 & 1.3 & 15.4 & 0.88 \\
\hline $108-664 \mathrm{~B}-3 \mathrm{H}-6,11$ & 26.61 & 81.4 & 2.3 & 16.3 & 0.83 \\
\hline $108-664 \mathrm{~B}-3 \mathrm{H}-6,19$ & 26.69 & 79.8 & 2.0 & 18.2 & 0.83 \\
\hline $108-664 \mathrm{~B}-3 \mathrm{H}-6,29$ & 26.79 & 81.7 & 2.2 & 16.1 & 0.84 \\
\hline $108-664 \mathrm{~B}-3 \mathrm{H}-6,41$ & 26.91 & 81.2 & 1.9 & 16.9 & 0.94 \\
\hline $108-664 \mathrm{~B}-3 \mathrm{H}-6,59$ & 27.09 & 84.0 & 1.9 & 14.1 & 0.88 \\
\hline $108-664 \mathrm{~B}-3 \mathrm{H}-6,71$ & 27.21 & 64.5 & 2.2 & 33.3 & 0.76 \\
\hline 108-664B-3H- 6,79 & 27.29 & 49.4 & 3.3 & 47.3 & 0.65 \\
\hline $108-664 \mathrm{~B}-3 \mathrm{H}-6,89$ & 27.39 & 49.5 & 4.0 & 46.6 & 0.64 \\
\hline $108-664 \mathrm{~B}-3 \mathrm{H}-6,101$ & 27.51 & 46.9 & 2.8 & 50.3 & 0.99 \\
\hline 108-664B-3H-6, 119 & 27.69 & 71.3 & 3.2 & 25.5 & 0.77 \\
\hline $108-664 \mathrm{~B}-3 \mathrm{H}-6,126$ & 27.76 & 89.8 & 3.0 & 7.2 & 0.83 \\
\hline $108-664 \mathrm{~B}-3 \mathrm{H}-6,139$ & 27.89 & 81.6 & 2.6 & 15.8 & 0.75 \\
\hline 108-664B-3H-6, 144 & 27.94 & 74.7 & 2.5 & 22.9 & 0.83 \\
\hline $108-664 \mathrm{~B}-4 \mathrm{H}-1,11$ & 28.61 & 80.0 & 2.0 & 18.0 & 0.79 \\
\hline 108-664B-4H-1, 19 & 28.69 & 76.5 & 1.9 & 21.6 & 0.76 \\
\hline $108-664 \mathrm{~B}-4 \mathrm{H}-1,29$ & 28.79 & 83.2 & 1.8 & 15.0 & 0.85 \\
\hline $108-664 \mathrm{~B}-4 \mathrm{H}-1,41$ & 28.91 & 80.3 & 1.7 & 17.9 & 0.81 \\
\hline $108-664 \mathrm{~B}-4 \mathrm{H}-1,59$ & 29.09 & 81.3 & 1.9 & 16.9 & 0.89 \\
\hline $108-664 \mathrm{~B}-4 \mathrm{H}-1,71$ & 29.21 & 69.8 & 2.3 & 27.9 & 0.85 \\
\hline $108-664 \mathrm{~B}-4 \mathrm{H}-1,79$ & 29.29 & 80.2 & 1.3 & 18.5 & 0.80 \\
\hline $108-664 \mathrm{~B}-4 \mathrm{H}-1,89$ & 29.39 & 82.5 & 2.6 & 14.9 & 0.96 \\
\hline 108-664B-4H-1, 101 & 29.51 & 83.8 & 2.2 & 14.0 & 0.90 \\
\hline $108-664 \mathrm{~B}-4 \mathrm{H}-1,119$ & 28.69 & 55.7 & 3.4 & 40.8 & 0.79 \\
\hline
\end{tabular}


Table 6 (continued).

\begin{tabular}{|c|c|c|c|c|c|}
\hline $\begin{array}{l}\text { Core, section, } \\
\text { interval }(\mathrm{cm})\end{array}$ & $\begin{array}{l}\text { Depth } \\
\text { (mbsf) }\end{array}$ & $\begin{array}{c}\mathrm{CaCO}_{3} \\
(\%)\end{array}$ & $\begin{array}{c}\mathrm{SiO}_{2} \\
(\%)\end{array}$ & $\begin{array}{c}\text { Terrigenous } \\
\text { fraction } \\
(\%)\end{array}$ & $\begin{array}{c}\text { Dry-bulk } \\
\text { density } \\
\left(\mathrm{g} / \mathrm{cm}^{3}\right)\end{array}$ \\
\hline $108-664 \mathrm{~B}-4 \mathrm{H}-1,126$ & 29.76 & 50.0 & 4.4 & 45.6 & 0.67 \\
\hline 108-664B-4H-1, 139 & 29.89 & 55.0 & 3.6 & 41.4 & 0.63 \\
\hline 108-664B-4H-1, 145 & 29.95 & 62.7 & 3.2 & 34.1 & 0.69 \\
\hline 108-664B-4H-2, 11 & 30.11 & 60.0 & 2.7 & 37.3 & 0.69 \\
\hline 108-664B-4H-2, 19 & 30.19 & 75.1 & 3.4 & 21.5 & 0.70 \\
\hline $108-664 \mathrm{~B}-4 \mathrm{H}-2,29$ & 30.29 & 76.5 & 2.7 & 20.8 & 0.76 \\
\hline 108-664B-4H-2, 41 & 30.41 & 78.8 & 2.8 & 18.4 & 0.79 \\
\hline 108-664B-4H-2, 59 & 30.59 & 60.6 & 2.9 & 36.5 & 0.78 \\
\hline 108-664B-4H-2, 71 & 30.71 & 55.5 & 3.5 & 40.9 & 0.71 \\
\hline 108-664B-4H-2, 79 & 30.79 & 64.1 & 3.5 & 32.4 & 0.71 \\
\hline 108-664B-4H-2, 89 & 30.89 & 80.4 & 2.6 & 17.0 & 0.99 \\
\hline $108-664 \mathrm{~B}-4 \mathrm{H}-2,101$ & 31.01 & 77.5 & 2.1 & 20.4 & 0.82 \\
\hline 108-664B-4H-2, 119 & 31.19 & 91.2 & 0.5 & 8.3 & 0.78 \\
\hline $108-664 \mathrm{~B}-4 \mathrm{H}-2,126$ & 31.26 & 78.0 & 3.4 & 18.6 & 0.70 \\
\hline $108-664 \mathrm{~B}-4 \mathrm{H}-2,139$ & 31.39 & 86.3 & 2.4 & 11.3 & 0.72 \\
\hline $108-664 \mathrm{~B}-4 \mathrm{H}-2,145$ & 31.45 & 83.8 & 2.1 & 14.0 & 0.79 \\
\hline $108-664 \mathrm{~B}-4 \mathrm{H}-3,11$ & 31.61 & 85.1 & 1.9 & 13.1 & 0.79 \\
\hline 108-664B- $4 \mathrm{H}-3,19$ & 31.69 & 84.2 & 2.2 & 13.6 & 0.72 \\
\hline $108-664 \mathrm{~B}-4 \mathrm{H}-3,29$ & 31.79 & 87.9 & 1.4 & 10.6 & 0.80 \\
\hline 108-664B-4H-3, 41 & 31.91 & 84.1 & 2.3 & 13.6 & 0.79 \\
\hline 108-664B-4H-3, 59 & 32.09 & 59.9 & 2.6 & 37.5 & 0.80 \\
\hline 108-664B-4H-3, 71 & 32.21 & 78.9 & 3.2 & 17.9 & 0.78 \\
\hline 108-664B-4H-3, 79 & 32.29 & 78.8 & 3.0 & 18.2 & 0.74 \\
\hline 108-664B-4H-3, 89 & 32.39 & 73.9 & 2.9 & 23.2 & 0.89 \\
\hline 108-664B-4H-3, 101 & 32.51 & 77.3 & 2.0 & 20.7 & 1.13 \\
\hline 108-664B-4H-3, 119 & 32.69 & 65.1 & 1.4 & 33.5 & 0.82 \\
\hline $108-664 \mathrm{~B}-4 \mathrm{H}-3,126$ & 32.76 & 59.2 & 2.5 & 38.3 & 0.75 \\
\hline 108-664B-4H-3, 139 & 32.89 & 78.4 & 2.2 & 19.5 & 0.85 \\
\hline $108-664 \mathrm{~B}-4 \mathrm{H}-3,145$ & 32.95 & 84.4 & 1.3 & 14.2 & 0.94 \\
\hline 108-664B-4H-4, 11 & 33.11 & 83.9 & 1.9 & 14.3 & 1.00 \\
\hline 108-664B-4H-4, 19 & 33.19 & 88.2 & 1.7 & 10.1 & 0.95 \\
\hline 108-664B-4H-4, 29 & 33.29 & 89.1 & 1.6 & 9.3 & 1.01 \\
\hline 108-664B-4H-4, 41 & 33.41 & 87.8 & 1.7 & 10.4 & 1.08 \\
\hline $108-664$ B- 4 H- 4,59 & 33.59 & 90.0 & 1.5 & 8.4 & 1.08 \\
\hline 108-664B-4H-4, 71 & 33.71 & 78.7 & 2.1 & 19.1 & 0.91 \\
\hline 108-664B-4H-4, 79 & 33.79 & 70.4 & 2.7 & 26.9 & 0.77 \\
\hline 108-664B-4H-4, 89 & 33.89 & 72.5 & 3.0 & 24.6 & 0.86 \\
\hline $108-664 \mathrm{~B}-4 \mathrm{H}-4,101$ & 34.01 & 86.2 & 1.2 & 12.6 & 0.84 \\
\hline $108-664 \mathrm{~B}-4 \mathrm{H}-4,119$ & 34.19 & 84.5 & 1.3 & 14.2 & 0.91 \\
\hline 108-664B-4H-4, 126 & 34.26 & 85.6 & 1.4 & 12.9 & 1.06 \\
\hline $108-664 \mathrm{~B}-4 \mathrm{H}-4,139$ & 34.39 & 87.6 & 1.5 & 10.9 & 0.91 \\
\hline 108-664B-4H-4, 145 & 34.45 & 87.4 & 1.4 & 11.2 & 1.01 \\
\hline 108-664B-4H-5, 8 & 34.58 & 84.7 & 1.5 & 13.8 & 1.01 \\
\hline 108-664B-4H-5, 19 & 34.69 & 84.5 & 1.4 & 14.0 & 0.91 \\
\hline $108-664 B-4 H-5,29$ & 34.79 & 77.3 & 1.8 & 20.9 & 0.92 \\
\hline 108-664B-4H-5, 41 & 34.91 & 81.8 & 1.6 & 16.6 & 0.94 \\
\hline 108-664B-4H-5, 59 & 35.08 & 87.8 & 1.6 & 10.6 & 1.31 \\
\hline 108-664B-4H-5, 71 & 35.21 & 87.8 & 1.7 & 10.5 & 0.90 \\
\hline 108-664B-4H-5, 79 & 35.29 & 89.3 & 1.1 & 9.5 & 0.94 \\
\hline 108-664B-4H-5, 89 & 35.39 & 90.7 & 1.1 & 8.2 & 1.06 \\
\hline $108-664 \mathrm{~B}-4 \mathrm{H}-5,101$ & 35.51 & 87.6 & 0.8 & 11.7 & 1.11 \\
\hline $108-664 \mathrm{~B}-4 \mathrm{H}-5,119$ & 35.69 & 85.2 & 1.3 & 13.4 & 1.02 \\
\hline 108-664B-4H-5, 126 & 35.76 & 81.6 & 1.5 & 16.9 & 1.01 \\
\hline 108-664B-4H-5, 139 & 35.89 & 83.3 & 1.3 & 15.4 & 0.90 \\
\hline 108-664B-4H-5, 145 & 35.95 & 67.6 & 1.6 & 30.8 & 1.03 \\
\hline $108-664 \mathrm{~B}-4 \mathrm{H}-6,11$ & 36.11 & 79.1 & 1.8 & 19.1 & 0.99 \\
\hline 108-664B-4H-6, 19 & 36.19 & 71.2 & 3.1 & 25.6 & 0.84 \\
\hline 108-664B-4H-6, 29 & 36.29 & 60.3 & 3.0 & 36.8 & 0.85 \\
\hline 108-664B-4H-6, 41 & 36.41 & 88.5 & 1.4 & 10.1 & 1.34 \\
\hline 108-664B-4H-6, 59 & 36.59 & 89.9 & 1.3 & 8.9 & 1.23 \\
\hline 108-664B-4H-6, 71 & 36.71 & 83.1 & 1.5 & 15.4 & 1.04 \\
\hline 108-664B-4H-6, 79 & 36.79 & 89.0 & 1.1 & 9.9 & 1.03 \\
\hline 108-664B-4H-6, 89 & 36.89 & 87.2 & 0.7 & 12.1 & 1.29 \\
\hline 108-664B-4H-6, 101 & 37.01 & 81.0 & 1.3 & 17.7 & 1.09 \\
\hline 108-664B-4H-6, 119 & 37.19 & 77.7 & 0.9 & 21.3 & 0.95 \\
\hline 108-664B-4H-6, 126 & 37.26 & 81.4 & 1.3 & 17.3 & 0.93 \\
\hline 108-664B-4H-6, 139 & 37.39 & 77.6 & 2.1 & 20.3 & 0.86 \\
\hline 108-664B-4H-6, 145 & 37.45 & 78.0 & 2.0 & 20.0 & 0.97 \\
\hline 108-664B-4H-7, 11 & 37.61 & 75.5 & 2.8 & 21.7 & 0.84 \\
\hline 108-664B-4H-7, 19 & 37.69 & 81.3 & 2.2 & 16.5 & 0.82 \\
\hline 108-664B-4H-7, 29 & 37.79 & 83.4 & 1.7 & 14.8 & 0.97 \\
\hline $108-664 \mathrm{~B}-4 \mathrm{H}-7,41$ & 37.91 & 89.5 & 1.4 & 9.1 & 1.01 \\
\hline $108-664 \mathrm{~B}-5 \mathrm{H}-1,59$ & 38.59 & 68.8 & 2.2 & 29.0 & 0.86 \\
\hline 108-664B-5H-1, 71 & 38.71 & 63.1 & 2.3 & 34.6 & 0.75 \\
\hline 108-664B-5H-1, 79 & 38.79 & 73.5 & 1.4 & 25.1 & 0.74 \\
\hline 108-664B-5H-1, 89 & 38.89 & 61.4 & 2.2 & 36.4 & 0.76 \\
\hline
\end{tabular}

Table 6 (continued).

\begin{tabular}{|c|c|c|c|c|c|}
\hline $\begin{array}{l}\text { Core, section, } \\
\text { interval }(\mathrm{cm})\end{array}$ & $\begin{array}{l}\text { Depth } \\
\text { (mbsf) }\end{array}$ & $\begin{array}{c}\mathrm{CaCO}_{3} \\
(\%)\end{array}$ & $\begin{array}{l}\mathrm{SiO}_{2} \\
(\%)\end{array}$ & $\begin{array}{l}\text { Terrigenous } \\
\text { fraction } \\
(\%)\end{array}$ & $\begin{array}{l}\text { Dry-bulk } \\
\text { density } \\
\left(\mathrm{g} / \mathrm{cm}^{3}\right)\end{array}$ \\
\hline 108-664B-5H-1, 101 & 39.01 & 84.1 & 1.4 & 14.5 & 0.90 \\
\hline 108-664B-5H-1, 119 & 39.19 & 85.2 & 1.7 & 13.2 & 1.04 \\
\hline $108-664 \mathrm{~B}-5 \mathrm{H}-1,126$ & 39.26 & 83.9 & 1.6 & 14.5 & 0.98 \\
\hline $108-664 \mathrm{~B}-5 \mathrm{H}-1,139$ & 39.39 & 72.1 & 1.7 & 26.2 & 0.79 \\
\hline $108-664 \mathrm{~B}-5 \mathrm{H}-1,146$ & 39.46 & 56.8 & 2.4 & 40.8 & 0.78 \\
\hline 108-664B-5H-2, 11 & 39.61 & 82.7 & 1.6 & 15.7 & 0.96 \\
\hline 108-664B-5H-2, 19 & 39.69 & 78.5 & 1.9 & 19.6 & 0.85 \\
\hline $108-664 \mathrm{~B}-5 \mathrm{H}-2,29$ & 39.79 & 83.2 & 1.1 & 15.6 & 0.95 \\
\hline 108-664B-5H-2, 41 & 39.91 & 80.1 & 2.0 & 17.9 & 0.90 \\
\hline $108-664 \mathrm{~B}-5 \mathrm{H}-2,59$ & 40.09 & 52.1 & 2.4 & 45.5 & 0.79 \\
\hline 108-664B-5H-2, 71 & 40.21 & 72.6 & 1.5 & 25.9 & 0.92 \\
\hline $108-664 \mathrm{~B}-5 \mathrm{H}-2,79$ & 40.29 & 76.0 & 1.4 & 22.5 & 0.88 \\
\hline $108-664 \mathrm{~B}-5 \mathrm{H}-2,89$ & 40.39 & 86.4 & 1.4 & 12.2 & 1.27 \\
\hline 108-664B-5H-2, 101 & 40.51 & 84.5 & 1.5 & 13.9 & 0.93 \\
\hline 108-664B-5H-2, 119 & 40.69 & 89.4 & 1.5 & 9.1 & 1.02 \\
\hline $108-664 \mathrm{~B}-5 \mathrm{H}-2,126$ & 40.76 & 88.0 & 1.6 & 10.4 & 0.99 \\
\hline 108-664B-5H-2, 139 & 40.89 & 87.7 & 1.8 & 10.6 & 0.91 \\
\hline $108-664 \mathrm{~B}-5 \mathrm{H}-2,146$ & 40.96 & 89.0 & 1.5 & 9.5 & 0.99 \\
\hline $108-664 \mathrm{~B}-5 \mathrm{H}-3,11$ & 41.11 & 87.2 & 1.3 & 11.4 & 1.01 \\
\hline $108-664 \mathrm{~B}-5 \mathrm{H}-3,19$ & 41.19 & 85.0 & 1.4 & 13.7 & 0.88 \\
\hline $108-664 \mathrm{~B}-5 \mathrm{H}-3,29$ & 41.29 & 85.0 & 1.4 & 13.6 & 1.03 \\
\hline $108-664 \mathrm{~B}-5 \mathrm{H}-3,41$ & 41.41 & 85.5 & 1.6 & 13.0 & 1.03 \\
\hline $108-664 \mathrm{~B}-5 \mathrm{H}-3,59$ & 41.59 & 85.1 & 1.5 & 13.4 & 1.11 \\
\hline $108-664 \mathrm{~B}-5 \mathrm{H}-3,71$ & 41.71 & 86.3 & 1.3 & 12.4 & 1.01 \\
\hline $108-664 \mathrm{~B}-5 \mathrm{H}-3,79$ & 41.79 & 87.2 & 1.2 & 11.6 & 0.90 \\
\hline $108-664 \mathrm{~B}-5 \mathrm{H}-3,89$ & 41.89 & 88.3 & 1.0 & 10.6 & 1.01 \\
\hline 108-664B-5H-3, 101 & 42.01 & 85.1 & 1.1 & 13.8 & 0.96 \\
\hline $108-664 \mathrm{~B}-5 \mathrm{H}-3,119$ & 42.19 & 78.2 & 2.2 & 19.6 & 0.88 \\
\hline $108-664 \mathrm{~B}-5 \mathrm{H}-3,126$ & 42.26 & 79.8 & 1.0 & 19.2 & 0.90 \\
\hline $108-664 \mathrm{~B}-5 \mathrm{H}-3,139$ & 42.39 & 86.4 & 1.7 & 11.9 & 0.82 \\
\hline $108-664 \mathrm{~B}-5 \mathrm{H}-3,146$ & 42.46 & 87.4 & 1.7 & 10.9 & 0.91 \\
\hline $108-664 \mathrm{~B}-5 \mathrm{H}-4,11$ & 42.61 & 87.5 & 1.4 & 11.2 & 1.03 \\
\hline $108-664 \mathrm{~B}-5 \mathrm{H}-4,19$ & 42.69 & 83.1 & 1.1 & 15.9 & 0.79 \\
\hline $108-664 \mathrm{~B}-5 \mathrm{H}-4,29$ & 42.79 & 80.7 & 1.1 & 18.3 & 0.86 \\
\hline $108-664 \mathrm{~B}-5 \mathrm{H}-4,41$ & 42.91 & 62.4 & 2.7 & 34.9 & 0.81 \\
\hline $108-664 \mathrm{~B}-5 \mathrm{H}-4,59$ & 43.09 & 49.4 & 2.0 & 48.7 & 0.79 \\
\hline $108-664 \mathrm{~B}-5 \mathrm{H}-4,71$ & 43.21 & 61.7 & 1.7 & 36.7 & 0.86 \\
\hline 108-664B- $5 \mathrm{H}-4,79$ & 43.29 & 75.1 & 1.0 & 23.9 & 0.82 \\
\hline $108-664$ B- $5 \mathrm{H}-4,89$ & 43.39 & 90.3 & 1.0 & 8.7 & 1.07 \\
\hline $108-664 \mathrm{~B}-5 \mathrm{H}-4,101$ & 43.51 & 90.3 & 0.9 & 8.8 & 1.05 \\
\hline 108-664B-5H-4, 119 & 43.69 & 84.3 & 1.3 & 14.4 & 0.98 \\
\hline 108-664B-5H-4, 126 & 43.76 & 86.3 & 1.0 & 12.6 & 1.06 \\
\hline 108-664B-5H-4, 139 & 43.89 & & 2.0 & & 0.79 \\
\hline 108-664B-5H-4, 146 & 43.96 & 69.4 & 2.3 & 28.3 & 0.83 \\
\hline 108-664B-5H-5, 11 & 44.11 & 67.4 & 2.5 & 30.0 & 0.82 \\
\hline 108-664B-5H-5, 19 & 44.19 & 48.9 & 2.5 & 48.5 & 0.64 \\
\hline 108-664B-5H-5, 29 & 44.29 & 64.6 & 3.0 & 32.4 & 0.93 \\
\hline 108-664B-5H-5, 41 & 44.41 & 78.0 & 2.2 & 19.7 & 0.88 \\
\hline 108-664B- $5 \mathrm{H}-5,59$ & 44.59 & 74.3 & 2.3 & 23.5 & 0.89 \\
\hline 108-664B-5H-5, 71 & 44.71 & 83.7 & 2.1 & 14.1 & 0.93 \\
\hline $108-664 \mathrm{~B}-5 \mathrm{H}-5,79$ & 44.79 & 81.8 & 1.9 & 16.3 & 0.84 \\
\hline 108-664B-5H-5, 89 & 44.89 & 67.4 & 2.6 & 29.9 & 0.86 \\
\hline 108-664B-5H-5, 101 & 45.01 & 77.7 & 2.0 & 20.3 & 0.97 \\
\hline 108-664B-5H-5, 119 & 45.19 & 85.2 & 1.7 & 13.1 & 0.98 \\
\hline 108-664B-5H-6, 11 & 45.61 & 71.8 & 1.6 & 26.6 & 1.00 \\
\hline 108-664B-5H-6, 19 & 45.69 & 78.4 & 1.6 & 20.0 & 0.82 \\
\hline 108-664B-5H-6, 29 & 45.79 & 81.5 & 1.4 & 17.1 & 0.92 \\
\hline $108-664 \mathrm{~B}-5 \mathrm{H}-6,41$ & 45.91 & 72.4 & 2.4 & 25.2 & 0.94 \\
\hline 108-664B-5H-6, 59 & 46.09 & 68.1 & 3.1 & 28.9 & 0.90 \\
\hline 108-664B-5H-6, 71 & 46.21 & 68.7 & 2.4 & 28.9 & 0.87 \\
\hline $108-664 \mathrm{~B}-5 \mathrm{H}-6,79$ & 46.29 & 72.5 & 2.4 & 25.2 & 0.77 \\
\hline $108-664 \mathrm{~B}-5 \mathrm{H}-6,89$ & 46.39 & 74.9 & 2.7 & 22.4 & 0.85 \\
\hline 108-664B-5H-6, 101 & 46.51 & 54.6 & 3.4 & 42.0 & 0.80 \\
\hline 108-664B-5H-6, 119 & 46.69 & 84.0 & 1.9 & 14.1 & 0.99 \\
\hline $108-664 \mathrm{~B}-5 \mathrm{H}-6,126$ & 46.76 & 70.6 & 2.2 & 27.3 & 0.92 \\
\hline $108-664 \mathrm{~B}-5 \mathrm{H}-6,139$ & 46.89 & 89.2 & 1.5 & 9.2 & 0.92 \\
\hline $108-664 \mathrm{~B}-5 \mathrm{H}-6,145$ & 46.95 & 92.6 & 1.9 & 5.6 & 1.05 \\
\hline 108-664B-5H-7, 11 & 47.11 & 87.2 & 1.7 & 11.2 & 1.06 \\
\hline 108-664B-5H-7, 19 & 47.19 & 89.0 & 1.7 & 9.3 & 0.88 \\
\hline $108-664$ B -5 H- 7,29 & 47.29 & 86.1 & 2.1 & 11.8 & 0.95 \\
\hline $108-664 \mathrm{~B}-5 \mathrm{H}-7,41$ & 47.41 & 88.1 & 1.8 & 10.1 & 0.96 \\
\hline $108-664 \mathrm{~B}-6 \mathrm{H}-1,29$ & 47.79 & 83.5 & 2.7 & 13.8 & 1.04 \\
\hline $108-664 \mathrm{~B}-6 \mathrm{H}-1,41$ & 47.91 & 86.8 & 2.0 & 11.2 & 1.05 \\
\hline $108-664 \mathrm{~B}-6 \mathrm{H}-1,59$ & 48.09 & 89.9 & 1.2 & 8.9 & 1.10 \\
\hline $108-664 \mathrm{~B}-6 \mathrm{H}-1,71$ & 48.21 & 92.5 & 1.2 & 6.3 & 1.02 \\
\hline $108-664 \mathrm{~B}-6 \mathrm{H}-1,79$ & 48.29 & 83.5 & 1.3 & 15.3 & 0.94 \\
\hline
\end{tabular}


Table 6 (continued).

\begin{tabular}{|c|c|c|c|c|c|}
\hline $\begin{array}{l}\text { Core, section, } \\
\text { interval }(\mathrm{cm})\end{array}$ & $\begin{array}{l}\text { Depth } \\
\text { (mbsf) }\end{array}$ & $\begin{array}{c}\mathrm{CaCO}_{3} \\
(\%)\end{array}$ & $\begin{array}{l}\mathrm{SiO}_{2} \\
(\%)\end{array}$ & $\begin{array}{c}\text { Terrigenous } \\
\text { fraction } \\
(\%)\end{array}$ & $\begin{array}{c}\text { Dry-bulk } \\
\text { density } \\
\left(\mathrm{g} / \mathrm{cm}^{3}\right)\end{array}$ \\
\hline 108-664B-6H-1, 89 & 48.39 & 87.9 & 1.5 & 10.6 & 0.99 \\
\hline 108-664B-6H-1, 101 & 48.51 & 84.2 & 1.7 & 14.1 & 1.02 \\
\hline 108-664B-6H-1, 119 & 48.69 & 84.0 & 1.1 & 14.9 & 0.94 \\
\hline 108-664B-6H-1, 126 & 48.76 & 87.4 & 1.4 & 11.2 & 1.06 \\
\hline 108-664B-6H-1, 139 & 48.89 & 85.5 & 1.5 & 13.0 & 0.95 \\
\hline 108-664B-6H-1, 146 & 48.95 & 82.6 & 1.7 & 15.7 & 1.09 \\
\hline 108-664B-6H-2, 11 & 49.11 & 83.5 & 1.4 & 15.1 & 1.13 \\
\hline 108-664B-6H-2, 19 & 49.19 & 87.1 & 1.4 & 11.5 & 0.91 \\
\hline 108-664B-6H-2, 29 & 49.29 & 83.2 & 1.6 & 15.2 & \\
\hline 108-664B-6H-2, 41 & 49.41 & 70.6 & 2.5 & 25.9 & 0.98 \\
\hline 108-664B-6H-2, 59 & 49.59 & 85.6 & 2.2 & 12.2 & 1.31 \\
\hline $108-664$ B- 6 H-2, 71 & 49.71 & 87.4 & 1.5 & 11.1 & 1.16 \\
\hline 108-664B-6H-2, 79 & 49.79 & 90.9 & 1.2 & 7.9 & 0.99 \\
\hline 108-664B-6H-2, 89 & 49.89 & 88.2 & 1.1 & 10.8 & 1.60 \\
\hline 108-664B-6H-2, 101 & 50.01 & 89.3 & 1.0 & 9.7 & 1.18 \\
\hline $108-664 \mathrm{~B}-6 \mathrm{H}-2,119$ & 50.19 & 89.3 & 1.1 & 9.6 & 1.09 \\
\hline 108-664B-6H-2, 126 & 50.26 & 83.6 & 1.2 & 15.2 & 1.06 \\
\hline 108-664B-6H-2, 139 & 50.39 & 82.4 & 1.5 & 16.1 & 0.90 \\
\hline 108-664B-6H-2, 146 & 50.46 & 83.4 & 1.4 & 15.1 & 1.26 \\
\hline 108-664B-6H-3, 11 & 50.61 & 77.7 & 1.5 & 20.8 & 1.04 \\
\hline 108-664B-6H-3, 19 & 50.69 & & 1.3 & & 0.95 \\
\hline 108-664B-6H-3, 29 & 50.79 & 71.0 & 2.0 & 26.9 & 1.13 \\
\hline $108-664 B-6 H-3,41$ & 50.91 & 82.2 & 1.1 & 16.7 & 0.98 \\
\hline 108-664B-6H-3, 59 & 51.09 & 89.6 & 1.0 & 9.5 & 1.10 \\
\hline $108-664 \mathrm{~B}-6 \mathrm{H}-3,71$ & 51.21 & 86.0 & 1.1 & 12.9 & 1.29 \\
\hline 108-664B-6H-3, 79 & 51.29 & 87.3 & 1.1 & 11.6 & 0.91 \\
\hline 108-664B-6H-3, 89 & 51.39 & 86.5 & 1.1 & 12.4 & 1.21 \\
\hline 108-664B-6H-3, 101 & 51.51 & 87.7 & 1.2 & 11.1 & 1.17 \\
\hline $108-664$ B- $6 \mathrm{H}-3,119$ & 51.69 & 86.3 & 1.1 & 12.6 & 0.98 \\
\hline $108-664 \mathrm{~B}-6 \mathrm{H}-3,126$ & 51.76 & 78.6 & 1.5 & 19.9 & 1.25 \\
\hline 108-664B-6H-3, 146 & 51.96 & 83.5 & 1.1 & 15.4 & 1.20 \\
\hline
\end{tabular}

Table 7 . Percentages of carbonate, opal, and terrigenous fraction, and dry-bulk densities at Hole 664D.

\begin{tabular}{|c|c|c|c|c|c|}
\hline $\begin{array}{l}\text { Core, section, } \\
\text { interval }(\mathrm{cm})\end{array}$ & $\begin{array}{l}\text { Depth } \\
\text { (mbsf) }\end{array}$ & $\begin{array}{c}\mathrm{CaCO}_{3} \\
(\%)\end{array}$ & $\underset{(\%)}{\mathrm{SiO}_{2}}$ & $\begin{array}{c}\text { Terrigenous } \\
\text { fraction } \\
(\%)\end{array}$ & $\begin{array}{c}\text { Dry-bulk } \\
\text { density } \\
\left(\mathrm{g} / \mathrm{cm}^{3}\right)\end{array}$ \\
\hline 108-664D-11H-1, 11 & 87.91 & 92.2 & 1.4 & 6.4 & 1.38 \\
\hline 108-664D-11H-1, 19 & 87.99 & 84.1 & 2.3 & 13.6 & 1.00 \\
\hline 108-664D-11H-1, 29 & 88.09 & 82.2 & 1.8 & 16.0 & 1.25 \\
\hline $108-664 \mathrm{D}-11 \mathrm{H}-1,41$ & 88.21 & 81.6 & 2.0 & 16.4 & 1.32 \\
\hline 108-664D-11H-1, 59 & 88.39 & 84.5 & 1.5 & 14.1 & 1.22 \\
\hline 108-664D-11H-1, 71 & 88.51 & 90.6 & 1.4 & 7.9 & 1.35 \\
\hline 108-664D-11H-1, 79 & 88.59 & 68.4 & 1.4 & 30.2 & 1.03 \\
\hline 108-664D-11H-1, 89 & 88.69 & 88.0 & 1.4 & 10.6 & 1.19 \\
\hline 108-664D-11H-1, 101 & 88.81 & 85.3 & 1.7 & 13.0 & 1.32 \\
\hline 108-664D-11H-1, 119 & 88.89 & 85.9 & 1.7 & 12.4 & 1.19 \\
\hline 108-664D-11H-1, 126 & 88.96 & 73.9 & 1.9 & 24.2 & 1.25 \\
\hline 108-664D-11H-1, 139 & 89.09 & 86.4 & 1.4 & 12.2 & 1.00 \\
\hline 108-664D-11H-1, 146 & 89.16 & 85.3 & 1.7 & 13.0 & 1.32 \\
\hline 108-664D-11H-2, 11 & 89.41 & 89.2 & 1.3 & 9.5 & \\
\hline 108-664D-11H-2, 19 & 89.49 & 91.2 & 1.0 & 7.8 & 1.07 \\
\hline $108-664 \mathrm{D}-11 \mathrm{H}-2,29$ & 89.59 & 92.4 & 1.0 & 6.6 & 1.37 \\
\hline $108-664 \mathrm{D}-11 \mathrm{H}-2,41$ & 89.71 & 90.8 & 1.1 & 8.1 & 1.35 \\
\hline $108-664 \mathrm{D}-11 \mathrm{H}-2,59$ & 89.89 & 90.2 & 1.3 & 8.6 & 1.36 \\
\hline 108-664D-11H-2, 71 & 90.01 & 87.6 & 1.2 & 11.2 & 1.19 \\
\hline 108-664D-11H-2, 79 & 90.09 & 82.9 & 1.3 & 15.8 & 1.10 \\
\hline 108-664D-11H-2, 89 & 90.19 & 86.5 & 1.1 & 12.4 & 1.27 \\
\hline 108-664D-11H-2, 101 & 90.31 & 83.4 & 1.6 & 15.0 & 1.41 \\
\hline 108-664D-11H-2, 119 & 90.49 & 88.1 & 1.6 & 10.4 & 1.23 \\
\hline 108-664D-11H-2, 126 & 90.56 & 88.0 & 1.7 & 10.3 & 1.22 \\
\hline 108-664D-11H-2, 139 & 90.69 & 87.0 & 1.5 & 11.5 & 1.00 \\
\hline 108-664D-11H-2, 146 & 90.76 & 82.6 & 2.2 & 15.2 & 1.18 \\
\hline 108-664D-11H-3, 11 & 90.91 & 81.4 & 1.6 & 17.0 & 1.39 \\
\hline 108-664D-11H-3, 19 & 90.99 & 86.4 & 1.5 & 12.1 & 1.04 \\
\hline 108-664D-11H-3, 29 & 91.09 & 84.3 & 1.6 & 14.2 & 1.29 \\
\hline $108-664 \mathrm{D}-11 \mathrm{H}-3,41$ & 91.21 & 80.1 & 1.9 & 18.1 & 1.36 \\
\hline $108-664 \mathrm{D}-11 \mathrm{H}-3,59$ & 91.39 & 90.8 & 1.4 & 7.7 & 1.27 \\
\hline $108-664 \mathrm{D}-11 \mathrm{H}-3,71$ & 91.51 & 85.3 & 1.7 & 13.1 & 1.28 \\
\hline $108-664 \mathrm{D}-11 \mathrm{H}-3,79$ & 91.59 & 89.4 & 1.4 & 9.2 & 1.06 \\
\hline 108-664D-11H-3, 89 & 91.69 & 91.7 & 1.1 & 7.2 & 1.44 \\
\hline
\end{tabular}

Table 7 (continued).

\begin{tabular}{|c|c|c|c|c|c|}
\hline $\begin{array}{l}\text { Core, section, } \\
\text { interval }(\mathrm{cm})\end{array}$ & $\begin{array}{l}\text { Depth } \\
\text { (mbsf) }\end{array}$ & $\begin{array}{c}\mathrm{CaCO}_{3} \\
(\%)\end{array}$ & $\begin{array}{l}\mathrm{SiO}_{2} \\
(\%)\end{array}$ & $\begin{array}{l}\text { Terrigenous } \\
\text { fraction } \\
(\%)\end{array}$ & $\begin{array}{c}\text { Dry-bulk } \\
\text { density } \\
\left(\mathrm{g} / \mathrm{cm}^{3}\right)\end{array}$ \\
\hline 108-664D-11H-3, 101 & 91.81 & 92.0 & 1.0 & 6.9 & 1.44 \\
\hline $108-664 \mathrm{D}-11 \mathrm{H}-3,119$ & 91.89 & 88.4 & 1.0 & 10.6 & 1.26 \\
\hline $108-664 \mathrm{D}-11 \mathrm{H}-3,126$ & 91.96 & 85.9 & 0.8 & 13.3 & 1.44 \\
\hline $108-664 \mathrm{D}-11 \mathrm{H}-3,139$ & 92.09 & 89.1 & 1.1 & 9.9 & 1.05 \\
\hline $108-664 \mathrm{D}-11 \mathrm{H}-3,146$ & 92.16 & 88.9 & 1.0 & 10.0 & 1.28 \\
\hline $108-664 \mathrm{D}-11 \mathrm{H}-4,11$ & 92.41 & 83.0 & 1.6 & 15.4 & 1.32 \\
\hline 108-664D-11H-4, 19 & 92.49 & 80.8 & 2.0 & 17.3 & 1.02 \\
\hline $108-664 \mathrm{D}-11 \mathrm{H}-4,29$ & 92.59 & 82.4 & 2.1 & 15.5 & 1.33 \\
\hline $108-664 \mathrm{D}-11 \mathrm{H}-4,41$ & 92.71 & 85.7 & 1.8 & 12.5 & 1.36 \\
\hline $108-664 \mathrm{D}-11 \mathrm{H}-4,59$ & 92.89 & 90.6 & 1.2 & 8.2 & 1.66 \\
\hline 108-664D-11H-4, 71 & 93.01 & 90.8 & 1.2 & 8.0 & 1.21 \\
\hline 108-664D-11H-4, 79 & 93.09 & 85.4 & 1.3 & 13.3 & 1.03 \\
\hline $108-664 \mathrm{D}-11 \mathrm{H}-4,89$ & 93.19 & 77.0 & 1.7 & 21.3 & 1.25 \\
\hline $108-664 \mathrm{D}-11 \mathrm{H}-4,101$ & 93.31 & 85.9 & 1.7 & 12.3 & 1.30 \\
\hline $108-664 \mathrm{D}-11 \mathrm{H}-4,119$ & 93.49 & 80.2 & 2.4 & 17.4 & 1.18 \\
\hline $108-664 \mathrm{D}-11 \mathrm{H}-4,126$ & 93.56 & 82.7 & 2.0 & 15.3 & 1.23 \\
\hline 108-664D-11H-4, 139 & 93.69 & 89.1 & 1.1 & 9.8 & 1.03 \\
\hline $108-664 \mathrm{D}-11 \mathrm{H}-4,146$ & 93.76 & 89.0 & 1.3 & 9.7 & 1.30 \\
\hline 108-664D-11H-5, 11 & 93.91 & 91.0 & 1.1 & 7.8 & 1.39 \\
\hline 108-664D-11H-5, 19 & 93.99 & 87.2 & 1.1 & 11.7 & 1.06 \\
\hline 108-664D-11H-5, 29 & 94.09 & 79.9 & 1.7 & 18.4 & 1.56 \\
\hline 108-664D-11H-5, 41 & 94.21 & 84.4 & 1.3 & 14.3 & 1.35 \\
\hline $108-664 \mathrm{D}-11 \mathrm{H}-5,59$ & 94.39 & 72.0 & 2.3 & 25.6 & 1.21 \\
\hline 108-664D-11H-5, 71 & 94.51 & 84.5 & 2.3 & 13.2 & 1.35 \\
\hline $108-664 \mathrm{D}-11 \mathrm{H}-5,79$ & 94.59 & 84.4 & 2.4 & 13.2 & 1.05 \\
\hline 108-664D-11H-5, 89 & 94.69 & 85.9 & 1.9 & 12.2 & 1.30 \\
\hline 108-664D-11H-5, 101 & 94.81 & 88.8 & 1.4 & 9.8 & \\
\hline 108-664D-11H-5, 119 & 94.99 & 89.3 & 1.4 & 9.4 & 1.29 \\
\hline 108-664D-11H-5, 126 & 95.06 & 91.3 & 1.1 & 7.6 & 1.51 \\
\hline 108-664D-11H-6, 11 & 95.41 & 91.7 & 1.3 & 7.1 & 1.65 \\
\hline 108-664D-11H-6, 19 & 95.49 & 89.9 & 1.4 & 8.7 & 1.12 \\
\hline 108-664D-11H-6, 29 & 95.59 & 89.7 & 1.4 & 8.9 & 1.46 \\
\hline $108-664 \mathrm{D}-11 \mathrm{H}-6,41$ & 95.71 & 88.9 & 1.4 & 9.7 & 1.46 \\
\hline $108-664 \mathrm{D}-11 \mathrm{H}-6,59$ & 95.89 & 84.7 & 1.3 & 13.9 & 1.39 \\
\hline 108-664D-11H-6, 89 & 96.19 & 83.8 & 1.9 & 14.4 & 1.33 \\
\hline 108-664D-11H-6, 101 & 96.31 & 88.3 & 1.6 & 10.2 & 1.45 \\
\hline 108-664D-11H-6, 119 & 96.49 & 82.3 & 1.6 & 16.2 & 1.34 \\
\hline 108-664D-11H-6, 126 & 96.56 & 69.0 & 2.5 & 28.5 & 1.36 \\
\hline 108-664D-11H-7, 11 & 96.91 & 84.2 & 1.6 & 14.2 & 1.23 \\
\hline 108-664D-11H-7, 19 & 96.99 & 86.6 & 1.9 & 11.5 & 1.06 \\
\hline 108-664D-11H-7, 29 & 97.09 & 68.0 & 1.6 & 30.5 & 1.42 \\
\hline 108-664D-11H-7, 41 & 97.21 & 91.2 & 1.3 & 7.5 & 1.63 \\
\hline $108-664 \mathrm{D}-11 \mathrm{H}-7,59$ & 97.39 & 89.2 & 1.2 & 9.6 & 1.52 \\
\hline 108-664D-12H-2, 11 & 98.91 & 88.6 & 1.3 & 10.2 & 1.53 \\
\hline 108-664D-12H-2, 19 & 98.99 & 86.2 & 1.1 & 12.7 & 1.09 \\
\hline $108-664 \mathrm{D}-12 \mathrm{H}-2,29$ & 99.09 & 71.3 & 1.8 & 27.0 & \\
\hline $108-664 \mathrm{D}-12 \mathrm{H}-2,41$ & 99.21 & 90.2 & 1.0 & 8.8 & 1.27 \\
\hline $108-664 \mathrm{D}-12 \mathrm{H}-2,59$ & 99.39 & 91.6 & 1.1 & 7.3 & \\
\hline $108-664 \mathrm{D}-12 \mathrm{H}-2,71$ & 99.51 & 83.8 & 1.6 & 14.6 & 1.32 \\
\hline $108-664 \mathrm{D}-12 \mathrm{H}-2,79$ & 99.59 & 88.7 & 1.2 & 10.1 & 1.04 \\
\hline $108-664 \mathrm{D}-12 \mathrm{H}-2,89$ & 99.69 & 89.6 & 1.2 & 9.2 & 1.28 \\
\hline 108-664D-12H-2, 101 & 99.81 & 85.1 & 1.8 & 13.1 & 1.19 \\
\hline 108-664D-12H-2, 119 & 99.99 & 92.5 & 1.2 & 6.3 & 1.38 \\
\hline $108-664 \mathrm{D}-12 \mathrm{H}-2,126$ & 100.06 & 89.3 & 1.1 & 9.5 & 1.52 \\
\hline 108-664D-12H-2, 139 & 100.19 & 91.6 & 1.1 & 7.3 & 1.07 \\
\hline 108-664D-12H-2, 145 & 100.25 & 89.9 & 1.1 & 9.0 & 1.35 \\
\hline $108-664 \mathrm{D}-12 \mathrm{H}-3,11$ & 100.41 & 90.4 & 1.2 & 8.5 & 1.43 \\
\hline 108-664D-12H-3, 19 & 100.49 & 89.6 & 1.2 & 9.2 & 1.07 \\
\hline $108-664 \mathrm{D}-12 \mathrm{H}-3,29$ & 100.59 & 92.8 & 1.3 & 5.9 & 1.50 \\
\hline $108-664 \mathrm{D}-12 \mathrm{H}-3,4 \mathrm{I}$ & 100.71 & 93.4 & 1.1 & 5.5 & 1.53 \\
\hline $108-664 \mathrm{D}-12 \mathrm{H}-3,59$ & 100.89 & 90.5 & 1.0 & 8.5 & 1.31 \\
\hline $108-664 \mathrm{D}-12 \mathrm{H}-3,71$ & 101.01 & 88.9 & 1.1 & 10.0 & 1.37 \\
\hline 108-664D-12H-3, 79 & 101.09 & 92.4 & 1.0 & 6.6 & 1.10 \\
\hline $108-664 \mathrm{D}-12 \mathrm{H}-3,89$ & 101.19 & 91.8 & 1.0 & 7.2 & 1.32 \\
\hline 108-664D-12H-3, 101 & 101.31 & 93.4 & 1.0 & 5.7 & 1.34 \\
\hline 108-664D-12H-3, 119 & 101.49 & 91.2 & 1.0 & 7.7 & \\
\hline 108-664D-12H-3, 126 & 101.56 & 93.9 & 0.9 & 5.2 & 1.33 \\
\hline 108-664D-12H-3, 139 & 101.69 & 86.2 & 0.9 & 12.9 & 1.11 \\
\hline $108-664 \mathrm{D}-12 \mathrm{H}-3,145$ & 101.75 & 93.2 & 1.0 & 5.8 & \\
\hline 108-664D-12H-4, 11 & 101.91 & 92.4 & 0.9 & 6.8 & 1.53 \\
\hline 108-664D-12H-4, 19 & 101.99 & 91.6 & 1.0 & 7.4 & 1.06 \\
\hline 108-664D-12H-4, 29 & 102.09 & 89.8 & 1.0 & 9.2 & 1.40 \\
\hline $108-664 \mathrm{D}-12 \mathrm{H}-4,41$ & 102.21 & 90.0 & 1.1 & 8.9 & 1.60 \\
\hline $108-664 \mathrm{D}-12 \mathrm{H}-4,59$ & 102.39 & 75.4 & 1.9 & 22.8 & 1.20 \\
\hline $108-664 \mathrm{D}-12 \mathrm{H}-4,71$ & 102.51 & 88.4 & 0.7 & 10.9 & 1.23 \\
\hline $108-664 \mathrm{D}-12 \mathrm{H}-4,79$ & 102.59 & 90.7 & 0.9 & 8.4 & 1.01 \\
\hline
\end{tabular}


Table 7 (continued).

\begin{tabular}{|c|c|c|c|c|c|}
\hline $\begin{array}{l}\text { Core, section, } \\
\text { interval }(\mathrm{cm})\end{array}$ & $\begin{array}{l}\text { Depth } \\
\text { (mbsf) }\end{array}$ & $\begin{array}{c}\mathrm{CaCO}_{3} \\
(\%)\end{array}$ & $\begin{array}{l}\mathrm{SiO}_{2} \\
(\%)\end{array}$ & $\begin{array}{c}\text { Terrigenous } \\
\text { fraction } \\
(\%)\end{array}$ & $\begin{array}{c}\text { Dry-bulk } \\
\text { density } \\
\left(\mathrm{g} / \mathrm{cm}^{3}\right)\end{array}$ \\
\hline $108-664 D-12 H-4,89$ & 102.69 & 91.3 & 1.0 & 7.7 & 1.35 \\
\hline 108-664D-12H-4, 101 & 102.81 & 87.9 & 1.0 & 11.1 & 1.16 \\
\hline $108-664 \mathrm{D}-12 \mathrm{H}-4,119$ & 102.99 & 91.0 & 1.1 & 7.9 & 1.18 \\
\hline 108-664D-12H-4, 126 & 103.06 & 77.6 & 1.6 & 20.9 & 1.31 \\
\hline $108-664 \mathrm{D}-12 \mathrm{H}-4,139$ & 103.19 & 86.8 & 1.3 & 11.9 & 0.99 \\
\hline 108-664D-12H-4, 145 & 103.25 & 91.0 & 1.2 & 7.8 & 1.55 \\
\hline 108-664D-12H-5, 11 & 103.41 & 90.3 & 1.0 & 8.7 & 1.48 \\
\hline 108-664D-12H-5, 19 & 103.49 & 85.5 & 1.0 & 13.5 & 1.04 \\
\hline 108-664D-12H-5, 29 & 103.59 & 60.6 & 3.4 & 36.0 & 1.18 \\
\hline 108-664D-12H-5, 41 & 103.71 & 89.0 & 1.3 & 9.8 & 1.30 \\
\hline $108-664 \mathrm{D}-12 \mathrm{H}-5,59$ & 103.89 & 89.2 & 0.8 & 10.0 & 1.36 \\
\hline 108-664D-12H-5, 71 & 104.01 & 94.1 & 0.9 & 5.0 & 1.25 \\
\hline $108-664 \mathrm{D}-12 \mathrm{H}-5,79$ & 104.09 & 93.8 & 1.0 & 5.2 & 1.25 \\
\hline $108-664 \mathrm{D}-12 \mathrm{H}-5,89$ & 104.19 & 93.5 & 0.8 & 5.7 & 1.03 \\
\hline $108-664 \mathrm{D}-12 \mathrm{H}-5,101$ & 104.31 & 92.1 & 1.1 & 6.9 & 1.29 \\
\hline $108-664 \mathrm{D}-12 \mathrm{H}-5,119$ & 104.49 & 90.4 & 1.1 & 8.4 & 1.34 \\
\hline 108-664D-12H-5, 126 & 104.56 & 91.1 & 1.1 & 7.8 & 1.48 \\
\hline 108-664D-12H-5, 139 & 104.69 & 91.8 & 1.2 & 7.0 & 1.05 \\
\hline $108-664 \mathrm{D}-12 \mathrm{H}-5,143$ & 104.73 & 91.0 & 1.3 & 7.7 & \\
\hline $108-664 \mathrm{D}-12 \mathrm{H}-6,11$ & 104.91 & 87.6 & 1.1 & 11.3 & \\
\hline $108-664 \mathrm{D}-12 \mathrm{H}-6,19$ & 104.99 & 75.1 & 1.4 & 23.5 & 0.94 \\
\hline $108-664 \mathrm{D}-12 \mathrm{H}-6,29$ & 105.09 & 56.0 & 2.8 & 41.2 & 1.25 \\
\hline $108-664 \mathrm{D}-12 \mathrm{H}-6,41$ & 105.21 & 89.7 & 1.8 & 8.6 & 1.39 \\
\hline $108-664 \mathrm{D}-12 \mathrm{H}-6,59$ & 105.39 & 81.6 & 1.3 & 17.2 & 1.22 \\
\hline $108-664 \mathrm{D}-12 \mathrm{H}-6,71$ & 105.51 & 75.6 & 2.0 & 22.4 & 1.23 \\
\hline 108-664D-12H-6, 79 & 105.59 & 84.9 & 1.3 & 13.8 & 1.03 \\
\hline $108-664 \mathrm{D}-12 \mathrm{H}-6,89$ & 105.69 & 93.1 & 1.1 & 5.7 & 1.29 \\
\hline $108-664 \mathrm{D}-12 \mathrm{H}-6,101$ & 105.81 & 92.9 & 1.0 & 6.1 & 1.25 \\
\hline $108-664 \mathrm{D}-12 \mathrm{H}-6,119$ & 105.99 & 90.4 & 1.1 & 8.5 & 1.41 \\
\hline $108-664 D-12 H-6,126$ & 106.06 & 73.5 & 1.1 & 25.4 & 1.27 \\
\hline $108-664 \mathrm{D}-12 \mathrm{H}-6,139$ & 106.19 & 88.9 & 1.2 & 9.9 & 1.05 \\
\hline $108-664 \mathrm{D}-12 \mathrm{H}-6,145$ & 106.25 & 86.5 & 1.3 & 12.2 & 1.44 \\
\hline $108-664 \mathrm{D}-12 \mathrm{H}-7,11$ & 106.41 & 68.2 & 2.3 & 29.6 & 1.14 \\
\hline $108-664 \mathrm{D}-12 \mathrm{H}-7,19$ & 106.49 & 86.4 & 1.8 & 11.8 & 0.98 \\
\hline 108-664D-12H-7, 29 & 106.59 & 84.2 & 1.3 & 14.6 & 1.18 \\
\hline $108-664 \mathrm{D}-12 \mathrm{H}-7,41$ & 106.71 & 84.1 & 1.3 & 14.6 & \\
\hline $108-664 \mathrm{D}-12 \mathrm{H}-7,59$ & 106.89 & 85.8 & 1.8 & 12.4 & 1.23 \\
\hline $108-664 \mathrm{D}-14 \mathrm{H}-3,19$ & 119.49 & 93.1 & 0.8 & 6.1 & 1.06 \\
\hline $108-664 \mathrm{D}-14 \mathrm{H}-3,29$ & 119.59 & 93.6 & 0.6 & 5.8 & 1.29 \\
\hline $108-664 \mathrm{D}-14 \mathrm{H}-3,59$ & 119.89 & 89.9 & 1.1 & 9.1 & 1.21 \\
\hline $108-664 \mathrm{D}-14 \mathrm{H}-3,79$ & 120.09 & 88.5 & 1.6 & 10.0 & 1.02 \\
\hline $108-664 \mathrm{D}-14 \mathrm{H}-3,89$ & 120.19 & 90.2 & 1.6 & 8.2 & 1.31 \\
\hline $108-664 \mathrm{D}-14 \mathrm{H}-3,119$ & 120.39 & 93.3 & 1.0 & 5.7 & 1.27 \\
\hline $108-664 \mathrm{D}-14 \mathrm{H}-3,139$ & 120.59 & 92.7 & 1.1 & 6.1 & 1.03 \\
\hline $108-664 \mathrm{D}-14 \mathrm{H}-3,146$ & 120.66 & 90.8 & 1.1 & 8.2 & 1.28 \\
\hline $108-664 \mathrm{D}-14 \mathrm{H}-4,19$ & 120.99 & 93.2 & 0.9 & 5.9 & 1.07 \\
\hline $108-664 \mathrm{D}-14 \mathrm{H}-4,29$ & 121.09 & 89.2 & 0.8 & 10.0 & 1.38 \\
\hline $108-664 \mathrm{D}-14 \mathrm{H}-4,59$ & 121.39 & 90.0 & 1.0 & 9.0 & 1.24 \\
\hline $108-664 \mathrm{D}-14 \mathrm{H}-4,77$ & 121.57 & 89.7 & 0.7 & 9.5 & 1.03 \\
\hline 108-664D-14H-4, 89 & 121.69 & 86.8 & 1.3 & 11.9 & 1.56 \\
\hline 108-664D-14H-4, 119 & 121.99 & 88.4 & 1.6 & 9.9 & 1.27 \\
\hline $108-664 \mathrm{D}-14 \mathrm{H}-4,139$ & 122.19 & 91.8 & 0.9 & 7.3 & 1.09 \\
\hline $108-664 \mathrm{D}-14 \mathrm{H}-4,146$ & 122.26 & 93.8 & 0.8 & 5.4 & 1.27 \\
\hline 108-664D-14H-5, 19 & 122.49 & 92.4 & 0.9 & 6.7 & 1.01 \\
\hline 108-664D-14H-5, 29 & 122.59 & 90.2 & 0.8 & 9.0 & 1.39 \\
\hline 108-664D-14H-5, 59 & 122.89 & 85.9 & 1.3 & 12.8 & 1.23 \\
\hline 108-664D-14H-5, 79 & 123.09 & 91.3 & 1.2 & 7.5 & 1.04 \\
\hline 108-664D-14H-5, 89 & 123.19 & 90.9 & 0.7 & 8.4 & 1.37 \\
\hline 108-664D-14H-5, 119 & 123.49 & 92.0 & 1.0 & 7.0 & 1.31 \\
\hline $108-664 \mathrm{D}-14 \mathrm{H}-5,139$ & 123.69 & 90.7 & 1.0 & 8.3 & 1.01 \\
\hline $108-664 \mathrm{D}-14 \mathrm{H}-5,146$ & 123.76 & 94.3 & 0.9 & 4.8 & 1.38 \\
\hline $108-664 \mathrm{D}-14 \mathrm{H}-6,19$ & 123.99 & 91.5 & 0.8 & 7.6 & 1.02 \\
\hline 108-664D-14H-6, 29 & 124.09 & 93.8 & 0.8 & 5.4 & 1.30 \\
\hline 108-664D-14H-6, 59 & 124.39 & 91.9 & 0.9 & 7.3 & 1.27 \\
\hline 108-664D-14H-6, 79 & 124.59 & 93.5 & 0.8 & 5.7 & 1.00 \\
\hline $108-664 \mathrm{D}-14 \mathrm{H}-6,89$ & 124.69 & 92.3 & 0.9 & 6.7 & \\
\hline 108-664D-14H-6, 119 & 124.99 & 92.6 & 1.3 & 6.2 & 1.22 \\
\hline $108-664 \mathrm{D}-14 \mathrm{H}-6,139$ & 125.19 & 69.4 & 0.9 & 29.7 & 1.03 \\
\hline 108-664D-14H-6, 144 & 125.24 & 92.6 & 1.0 & 6.4 & 1.29 \\
\hline $108-664 \mathrm{D}-14 \mathrm{H}-7,11$ & 125.41 & 90.8 & 1.1 & 8.1 & 12.5 \\
\hline 108-664D-14H-7, 19 & 125.49 & 87.3 & 1.1 & 11.5 & 1.02 \\
\hline 108-664D-14H-7, 29 & 125.59 & 88.9 & 1.3 & 9.9 & 1.30 \\
\hline 108-664D-15H-1, 70 & 126.50 & 92.0 & 1.0 & 7.0 & \\
\hline 108-664D-15H-1, 80 & 126.60 & 93.8 & 1.0 & 5.2 & \\
\hline $108-664$ D- 15 H- 1,89 & 126.69 & 91.2 & & & \\
\hline $108-664 \mathrm{D}-15 \mathrm{H}-1,100$ & 126.80 & 92.8 & 0.9 & 6.3 & \\
\hline
\end{tabular}

Table 7 (continued).

\begin{tabular}{|c|c|c|c|c|c|}
\hline $\begin{array}{l}\text { Core, section, } \\
\text { interval }(\mathrm{cm})\end{array}$ & $\begin{array}{l}\text { Depth } \\
\text { (mbsf) }\end{array}$ & $\begin{array}{c}\mathrm{CaCO}_{3} \\
(\%)\end{array}$ & $\begin{array}{l}\mathrm{SiO}_{2} \\
(\%)\end{array}$ & $\begin{array}{l}\text { Terrigenous } \\
\text { fraction } \\
(\%)\end{array}$ & $\begin{array}{l}\text { Dry-bulk } \\
\text { density } \\
\left(\mathrm{g} / \mathrm{cm}^{3}\right)\end{array}$ \\
\hline $108-664 \mathrm{D}-15 \mathrm{H}-1,110$ & 126.90 & 92.0 & 0.4 & 7.6 & \\
\hline $108-664 \mathrm{D}-15 \mathrm{H}-1,120$ & 127.00 & 92.7 & 0.5 & 6.8 & \\
\hline $108-664 \mathrm{D}-15 \mathrm{H}-1,130$ & 127.10 & 93.9 & 1.0 & 5.1 & \\
\hline $108-664 \mathrm{D}-15 \mathrm{H}-2,10$ & 127.40 & 93.0 & 1.1 & 6.0 & \\
\hline $108-664 \mathrm{D}-15 \mathrm{H}-2,29$ & 127.59 & 93.9 & 1.1 & 4.9 & \\
\hline $108-664 \mathrm{D}-15 \mathrm{H}-2,30$ & 127.70 & 93.4 & 0.9 & 5.7 & \\
\hline $108-664 \mathrm{D}-15 \mathrm{H}-2,50$ & 127.80 & 92.7 & 0.8 & 6.5 & \\
\hline $108-664 \mathrm{D}-15 \mathrm{H}-2,60$ & 127.90 & 93.4 & 0.6 & 6.0 & \\
\hline 108-664D-15H-2, 70 & 128.00 & 93.6 & 0.7 & 5.8 & \\
\hline $108-664 \mathrm{D}-15 \mathrm{H}-2,90$ & 128.20 & 93.3 & 0.4 & 6.3 & \\
\hline $108-664 \mathrm{D}-15 \mathrm{H}-2,100$ & 128.30 & 92.6 & 0.7 & 6.7 & \\
\hline 108-664D-15H-2, 110 & 128.40 & 92.1 & 0.7 & 7.2 & \\
\hline $108-664 \mathrm{D}-15 \mathrm{H}-2,120$ & 128.50 & 91.8 & 0.6 & 7.6 & \\
\hline 108-664D-15H-2, 130 & 128.60 & 92.0 & 0.9 & 7.1 & \\
\hline $108-664 \mathrm{D}-15 \mathrm{H}-2,147$ & 128.77 & 91.7 & 1.0 & 7.3 & \\
\hline $108-664 \mathrm{D}-15 \mathrm{H}-3,10$ & 128.90 & 91.3 & 0.9 & 7.8 & \\
\hline $108-664 \mathrm{D}-15 \mathrm{H}-3,30$ & 129.10 & 89.8 & 0.8 & 9.4 & \\
\hline $108-664 \mathrm{D}-15 \mathrm{H}-3,40$ & 129.20 & 92.7 & 1.0 & 6.3 & \\
\hline $108-664 \mathrm{D}-15 \mathrm{H}-3,50$ & 129.30 & 91.6 & 0.8 & 7.6 & \\
\hline $108-664 \mathrm{D}-15 \mathrm{H}-3,60$ & 129.40 & 91.8 & 0.7 & 7.5 & \\
\hline $108-664 \mathrm{D}-15 \mathrm{H}-3,70$ & 129.50 & 95.0 & 0.6 & 4.4 & \\
\hline $108-664 \mathrm{D}-15 \mathrm{H}-3,90$ & 129.70 & 90.3 & 0.3 & 9.5 & \\
\hline $108-664 \mathrm{D}-15 \mathrm{H}-3,100$ & 129.80 & 90.0 & 0.7 & 9.2 & \\
\hline $108-664 \mathrm{D}-15 \mathrm{H}-3,110$ & 129.90 & 91.1 & 0.6 & 8.4 & \\
\hline $108-664 \mathrm{D}-15 \mathrm{H}-3,120$ & 130.0 & 89.5 & 0.6 & 9.8 & \\
\hline $108-664 \mathrm{D}-15 \mathrm{H}-3,130$ & 130.10 & 92.2 & 0.6 & 7.2 & \\
\hline $108-664 \mathrm{D}-15 \mathrm{H}-3,149$ & 130.29 & 19.5 & 0.4 & 8.1 & \\
\hline $108-664 \mathrm{D}-15 \mathrm{H}-4,10$ & 130.40 & 90.7 & 0.6 & 8.7 & \\
\hline $108-664 \mathrm{D}-15 \mathrm{H}-4,28$ & 130.58 & 84.8 & 1.3 & 13.9 & \\
\hline $108-664 \mathrm{D}-15 \mathrm{H}-4,40$ & 130.70 & 89.0 & 0.8 & 10.2 & \\
\hline $108-664 \mathrm{D}-15 \mathrm{H}-4,50$ & 130.80 & 90.9 & 0.7 & 8.4 & \\
\hline $108-664 \mathrm{D}-15 \mathrm{H}-4,60$ & 130.90 & 92.1 & 0.6 & 7.3 & \\
\hline $108-664 \mathrm{D}-15 \mathrm{H}-4,70$ & 131.00 & 92.1 & 0.6 & 7.3 & \\
\hline $108-664 \mathrm{D}-15 \mathrm{H}-4,90$ & 131.20 & 90.1 & 0.8 & 9.1 & \\
\hline $108-664 \mathrm{D}-15 \mathrm{H}-4,100$ & 131.30 & 90.2 & 0.9 & 9.0 & \\
\hline $108-664 \mathrm{D}-15 \mathrm{H}-4,110$ & 131.40 & 91.2 & 0.6 & 8.2 & \\
\hline 108-664D-15H-4, 119 & 131.49 & 91.8 & 0.8 & 7.3 & \\
\hline $108-664 \mathrm{D}-15 \mathrm{H}-4,130$ & 131.60 & 92.4 & 1.0 & 6.6 & \\
\hline 108-664D-15H-4, 148 & 131.78 & 93.8 & 1.0 & 5.3 & \\
\hline $108-664 \mathrm{D}-15 \mathrm{H}-5,10$ & 131.90 & 91.8 & 0.8 & 7.4 & \\
\hline 108-664D-15H-5, 28 & 132.08 & 85.8 & 1.0 & 13.3 & \\
\hline $108-664 \mathrm{D}-15 \mathrm{H}-5,40$ & 132.20 & 84.5 & 1.4 & 14.1 & \\
\hline 108-664D-15H-5, 50 & 132.30 & 89.8 & 1.0 & 9.1 & \\
\hline $108-664 \mathrm{D}-15 \mathrm{H}-5,60$ & 132.40 & 91.9 & 1.3 & 6.8 & \\
\hline $108-664 \mathrm{D}-15 \mathrm{H}-5,70$ & 132.50 & 92.8 & 1.0 & 6.2 & \\
\hline $108-664 \mathrm{D}-15 \mathrm{H}-5,90$ & 132.70 & 92.5 & 0.6 & 6.9 & \\
\hline $108-664 \mathrm{D}-15 \mathrm{H}-5,100$ & 132.80 & 92.4 & 1.0 & 6.6 & \\
\hline $108-664 \mathrm{D}-15 \mathrm{H}-5,110$ & 132.90 & 92.6 & 1.1 & 6.3 & \\
\hline $108-664 \mathrm{D}-15 \mathrm{H}-5,119$ & 132.99 & 92.0 & 1.1 & 6.9 & \\
\hline $108-664 \mathrm{D}-15 \mathrm{H}-5,130$ & 133.10 & 91.9 & 1.1 & 7.0 & \\
\hline $108-664 \mathrm{D}-15 \mathrm{H}-5,148$ & 133.28 & 90.1 & 0.9 & 9.0 & \\
\hline $108-664 \mathrm{D}-15 \mathrm{H}-6,10$ & 133.40 & 85.8 & 1.1 & 13.1 & \\
\hline $108-664 \mathrm{D}-15 \mathrm{H}-6,28$ & 133.58 & 91.6 & 1.0 & 7.5 & \\
\hline $108-664 \mathrm{D}-15 \mathrm{H}-6,40$ & 133.70 & 91.0 & 0.9 & 8.0 & \\
\hline $108-664 \mathrm{D}-15 \mathrm{H}-6,50$ & 133.80 & 91.1 & 0.8 & 8.1 & \\
\hline $108-664 \mathrm{D}-15 \mathrm{H}-6,60$ & 133.90 & 92.7 & 1.0 & 6.4 & \\
\hline $108-664 \mathrm{D}-15 \mathrm{H}-6,70$ & 134.00 & 92.8 & 0.8 & 6.3 & \\
\hline 108-664D-15H-6, 90 & 134.20 & 90.5 & 1.1 & 8.4 & \\
\hline 108-664D-15H-6, 100 & 134.30 & 86.1 & 1.6 & 12.3 & \\
\hline 108-664D-15H-6, 110 & 134.40 & 81.0 & 1.7 & 17.3 & \\
\hline 108-664D-15H-6, 119 & 134.49 & 83.7 & 1.4 & 14.9 & \\
\hline $108-664 \mathrm{D}-15 \mathrm{H}-6,130$ & 134.60 & 90.6 & 1.1 & 8.3 & \\
\hline 108-664D-15H-6, 148 & 134.78 & 89.1 & 1.0 & 9.9 & \\
\hline 108-664D-15H-7, 10 & 134.90 & 90.8 & 1.1 & 8.1 & \\
\hline $108-664 \mathrm{D}-15 \mathrm{H}-7,28$ & 135.08 & 90.6 & 1.1 & 8.3 & \\
\hline 108-664D-15H-7, 40 & 135.20 & 92.7 & 1.2 & 6.1 & \\
\hline $108-664 \mathrm{D}-15 \mathrm{H}-7,50$ & 135.30 & 85.7 & 1.3 & 13.0 & \\
\hline $108-664 \mathrm{D}-15 \mathrm{H}-7,55$ & 135.35 & 86.5 & 1.4 & 12.1 & \\
\hline $108-664 \mathrm{D}-16 \mathrm{H}-2,10$ & 136.90 & 90.5 & 0.7 & 8.9 & \\
\hline $108-664 \mathrm{D}-16 \mathrm{H}-2,27$ & 137.07 & 89.1 & 1.1 & 9.8 & \\
\hline $108-664 \mathrm{D}-16 \mathrm{H}-2,40$ & 137.20 & 89.1 & 0.9 & 10.1 & \\
\hline $108-664 \mathrm{D}-16 \mathrm{H}-2,50$ & 137.30 & 90.7 & 0.9 & 8.3 & \\
\hline $108-664 \mathrm{D}-16 \mathrm{H}-2,60$ & 137.40 & 89.3 & 1.0 & 9.7 & \\
\hline $108-664 \mathrm{D}-16 \mathrm{H}-2,70$ & 137.50 & 88.2 & 1.1 & 10.7 & \\
\hline $108-664 \mathrm{D}-16 \mathrm{H}-2,90$ & 137.70 & 91.0 & 1.1 & 7.9 & \\
\hline $108-664 \mathrm{D}-16 \mathrm{H}-2,100$ & 137.80 & 91.0 & 1.0 & 8.0 & \\
\hline
\end{tabular}


Table 7 (continued).

\begin{tabular}{|c|c|c|c|c|c|}
\hline $\begin{array}{l}\text { Core, section, } \\
\text { interval }(\mathrm{cm})\end{array}$ & $\begin{array}{l}\text { Depth } \\
\text { (mbsf) }\end{array}$ & $\underset{(\%)}{\mathrm{CaCO}_{3}}$ & $\begin{array}{c}\mathrm{SiO}_{2} \\
(\%)\end{array}$ & $\begin{array}{c}\text { Terrigenous } \\
\text { fraction } \\
(\%)\end{array}$ & $\begin{array}{c}\text { Dry-bulk } \\
\text { density } \\
\left(\mathrm{g} / \mathrm{cm}^{3}\right)\end{array}$ \\
\hline $108-664 \mathrm{D}-16 \mathrm{H}-2,110$ & 137.90 & 90.0 & 0.9 & 9.1 & \\
\hline $108-664 \mathrm{D}-16 \mathrm{H}-2,120$ & 138.00 & 88.6 & 1.0 & 10.5 & \\
\hline 108-664D-16H-2, 129 & 138.09 & 89.8 & 0.9 & 9.2 & \\
\hline $108-664 \mathrm{D}-16 \mathrm{H}-2,150$ & 138.30 & 81.8 & 1.9 & 16.3 & \\
\hline 108-664D-16H-3, 10 & 138.40 & 86.1 & 1.3 & 12.6 & \\
\hline $108-664 \mathrm{D}-16 \mathrm{H}-3,27$ & 138.57 & 90.8 & 0.9 & 8.3 & \\
\hline $108-664 \mathrm{D}-16 \mathrm{H}-3,40$ & 138.70 & 91.6 & 1.0 & 7.4 & \\
\hline $108-664 \mathrm{D}-16 \mathrm{H}-3,50$ & 138.80 & 91.8 & 1.0 & 7.2 & \\
\hline $108-664 \mathrm{D}-16 \mathrm{H}-3,60$ & 138.90 & 89.3 & 1.2 & 9.6 & \\
\hline 108-664D-16H-3, 70 & 139.00 & 87.4 & 1.3 & 11.4 & \\
\hline $108-664 \mathrm{D}-16 \mathrm{H}-3,90$ & 139.20 & 90.2 & 0.9 & 8.9 & \\
\hline 108-664D-16H-3, 100 & 139.30 & 92.4 & 1.0 & 6.6 & \\
\hline $108-664 \mathrm{D}-16 \mathrm{H}-3,110$ & 139.40 & 90.4 & 1.0 & 8.6 & \\
\hline 108-664D-16H-3, 120 & 139.50 & 93.4 & 0.4 & 6.2 & \\
\hline 108-664D-16H-3, 133 & 139.63 & 90.6 & 0.5 & 8.9 & \\
\hline $108-664 \mathrm{D}-16 \mathrm{H}-3,140$ & 139.70 & 90.3 & & & \\
\hline 108-664D-16H-3, 149 & 139.79 & 91.4 & & & \\
\hline $108-664 \mathrm{D}-16 \mathrm{H}-4,10$ & 139.90 & 90.7 & & & \\
\hline $108-664 \mathrm{D}-16 \mathrm{H}-4,30$ & 140.10 & 92.7 & & & \\
\hline $108-664 \mathrm{D}-16 \mathrm{H}-5,30$ & 141.60 & 91.5 & & & \\
\hline $108-664 \mathrm{D}-16 \mathrm{H}-5,40$ & 141.70 & 94.5 & & & \\
\hline 108-664D-16H-5, 50 & 141.80 & 93.3 & & & \\
\hline $108-664 \mathrm{D}-16 \mathrm{H}-5,60$ & 141.90 & 94.6 & & & \\
\hline 108-664D-16H-5, 70 & 142.00 & 93.0 & 0.3 & 6.7 & \\
\hline 108-664D-16H-5, 90 & 142.20 & 94.5 & 0.3 & 5.2 & \\
\hline $108-664 \mathrm{D}-16 \mathrm{H}-5,100$ & 142.30 & 91.8 & 0.4 & 7.8 & \\
\hline 108-664D-16H-5, 110 & 142.40 & 93.7 & 0.4 & 5.9 & \\
\hline 108-664D-16H-5, 119 & 142.49 & 93.7 & 0.3 & 6.1 & \\
\hline 108-664D-16H-5, 133 & 142.63 & 96.4 & 0.3 & 3.3 & \\
\hline 108-664D-16H-5, 149 & 142.79 & 91.9 & 0.4 & 7.6 & \\
\hline $108-664 \mathrm{D}-16 \mathrm{H}-6,10$ & 142.90 & 91.0 & 0.4 & 8.6 & \\
\hline 108-664D-16H-6, 27 & 143.07 & 90.2 & 0.4 & 9.4 & \\
\hline 108-664D-16H-6, 40 & 143.20 & 91.0 & 0.1 & 8.9 & \\
\hline $108-664 \mathrm{D}-16 \mathrm{H}-6,50$ & 143.30 & 91.4 & 0.4 & 8.2 & \\
\hline $108-664 \mathrm{D}-16 \mathrm{H}-6,60$ & 143.40 & 92.9 & 0.2 & 7.0 & \\
\hline $108-664 \mathrm{D}-16 \mathrm{H}-6,70$ & 143.50 & 91.1 & 0.3 & 8.6 & \\
\hline 108-664D-16H-6, 90 & 143.70 & 92.0 & 0.1 & 7.9 & \\
\hline 108-664D-16H-6, 100 & 143.80 & 91.2 & 0.4 & 8.4 & \\
\hline 108-664D-16H-6, 110 & 143.90 & 90.7 & 0.2 & 9.1 & \\
\hline 108-664D-16H-6, 120 & 144.00 & 91.0 & 0.5 & 8.5 & \\
\hline 108-664D-16H-6, 133 & 144.13 & 92.1 & 0.6 & 7.3 & \\
\hline 108-664D-16H-6, 149 & 144.29 & 88.4 & 0.3 & 11.3 & \\
\hline $108-664 \mathrm{D}-16 \mathrm{H}-7,10$ & 144.40 & 87.5 & 0.4 & 12.1 & \\
\hline 108-664D-16H-7, 27 & 144.57 & 91.7 & 0.5 & 7.8 & \\
\hline $108-664 \mathrm{D}-16 \mathrm{H}-7,40$ & 144.70 & 92.7 & 0.2 & 7.1 & \\
\hline $108-664 \mathrm{D}-16 \mathrm{H}-7,50$ & 144.80 & 91.9 & 0.6 & 7.5 & \\
\hline $108-664 \mathrm{D}-16 \mathrm{H}-7,60$ & 144.90 & 90.9 & 0.1 & 8.9 & \\
\hline $108-664 \mathrm{D}-16 \mathrm{H}-7,70$ & 145.00 & 92.6 & 0.2 & 7.2 & \\
\hline 108-664D-16H-7, 79 & 145.09 & 91.1 & 0.4 & 8.5 & \\
\hline 108-664D-17H-1, 40 & 145.20 & 93.1 & 0.2 & 6.6 & \\
\hline 108-664D-17H-1, 50 & 145.30 & 92.8 & 0.2 & 7.1 & \\
\hline $108-664 \mathrm{D}-17 \mathrm{H}-1,60$ & 145.40 & 91.8 & 0.5 & 7.7 & \\
\hline 108-664D-17H-1, 70 & 145.50 & 91.2 & 0.2 & 8.6 & \\
\hline 108-664D-17H-1, 90 & 145.70 & 92.5 & 0.2 & 7.3 & \\
\hline 108-664D-17H-1, 100 & 145.80 & 92.7 & 0.1 & 7.2 & \\
\hline 108-664D-17H-1, 110 & 145.90 & 92.7 & 0.1 & 7.3 & \\
\hline 108-664D-17H-1, 120 & 146.00 & 93.2 & 0.2 & 6.6 & \\
\hline $108-664 \mathrm{D}-17 \mathrm{H}-1,133$ & 146.13 & 93.4 & 0.1 & 6.5 & \\
\hline 108-664D-17H-4, 149 & 150.79 & 93.9 & 0.1 & 6.0 & \\
\hline 108-664D-17H-5, 10 & 150.90 & 94.1 & 0.1 & 5.8 & \\
\hline 108-664D-17H-5, 27 & 151.07 & 92.1 & 0.1 & 7.7 & \\
\hline 108-664D-17H-5, 40 & 151.20 & 90.9 & 0.1 & 9.0 & \\
\hline 108-664D-17H-5, 50 & 151.30 & 90.9 & 0.6 & 8.4 & \\
\hline 108-664D-17H-5, 60 & 151.40 & 91.0 & 0.8 & 8.2 & \\
\hline $108-664 \mathrm{D}-17 \mathrm{H}-5,70$ & 151.50 & 92.8 & 0.7 & 6.5 & \\
\hline $108-664 \mathrm{D}-17 \mathrm{H}-5,90$ & 151.70 & 94.9 & 0.3 & 4.8 & \\
\hline 108-664D-17H-5, 100 & 151.80 & 93.6 & 0.6 & 5.8 & \\
\hline 108-664D-17H-5, 110 & 151.90 & 93.2 & 0.6 & 6.2 & \\
\hline $108-664 \mathrm{D}-17 \mathrm{H}-5,120$ & 152.00 & 92.7 & 0.5 & 6.8 & \\
\hline 108-664D-17H-5, 123 & 152.03 & 94.0 & 0.5 & 5.5 & \\
\hline 108-664D-17H-5, 146 & 152.26 & 92.1 & 0.6 & 7.3 & \\
\hline 108-664D-17H-6, 10 & 152.40 & 93.6 & 0.6 & 5.8 & \\
\hline 108-664D-17H-6, 27 & 152.57 & 93.5 & 0.3 & 6.3 & \\
\hline $108-664 \mathrm{D}-17 \mathrm{H}-6,40$ & 152.70 & 93.7 & 0.6 & 5.7 & \\
\hline 108-664D-17H-6, 50 & 152.80 & 93.2 & 0.8 & 6.0 & \\
\hline $108-664 \mathrm{D}-17 \mathrm{H}-6,60$ & 152.90 & 88.9 & 0.9 & 10.2 & \\
\hline
\end{tabular}

Table 7 (continued).

\begin{tabular}{|c|c|c|c|c|c|}
\hline $\begin{array}{l}\text { Core, section, } \\
\text { interval }(\mathrm{cm})\end{array}$ & $\begin{array}{l}\text { Depth } \\
\text { (mbsf) }\end{array}$ & $\begin{array}{c}\mathrm{CaCO}_{3} \\
(\%)\end{array}$ & $\begin{array}{c}\mathrm{SiO}_{2} \\
(\%)\end{array}$ & $\begin{array}{l}\text { Terrigenous } \\
\text { fraction } \\
(\%)\end{array}$ & $\begin{array}{c}\text { Dry-bulk } \\
\text { density } \\
\left(\mathrm{g} / \mathrm{cm}^{3}\right)\end{array}$ \\
\hline $108-664 \mathrm{D}-17 \mathrm{H}-6,70$ & 153.00 & 89.2 & 1.1 & 9.7 & \\
\hline $108-664 \mathrm{D}-17 \mathrm{H}-6,90$ & 153.20 & 94.8 & 0.6 & 4.7 & \\
\hline $108-664 \mathrm{D}-17 \mathrm{H}-6,100$ & 153.30 & 94.5 & 0.5 & 5.0 & \\
\hline $108-664 \mathrm{D}-17 \mathrm{H}-6,110$ & 153.40 & 93.4 & 0.6 & 6.0 & \\
\hline $108-664 \mathrm{D}-17 \mathrm{H}-6,120$ & 153.50 & 94.3 & 0.7 & 5.0 & \\
\hline $108-664 \mathrm{D}-17 \mathrm{H}-6,130$ & 153.60 & 90.9 & 0.8 & 8.2 & \\
\hline $108-664 \mathrm{D}-17 \mathrm{H}-6,149$ & 153.79 & 94.6 & 0.6 & 4.8 & \\
\hline $108-664 \mathrm{D}-17 \mathrm{H}-7,10$ & 153.90 & 95.0 & 0.6 & 4.5 & \\
\hline $108-664 \mathrm{D}-17 \mathrm{H}-7,27$ & 154.07 & 93.5 & 0.6 & 5.9 & \\
\hline $108-664 \mathrm{D}-17 \mathrm{H}-7,40$ & 154.20 & 93.8 & 0.4 & 5.9 & \\
\hline $108-664 \mathrm{D}-17 \mathrm{H}-7,48$ & 154.28 & 92.3 & 0.9 & 6.8 & \\
\hline $108-664 \mathrm{D}-18 \mathrm{H}-1,1$ & 154.31 & 92.1 & 0.8 & 7.1 & \\
\hline $108-664 \mathrm{D}-18 \mathrm{H}-1,10$ & 154.40 & 93.7 & 0.8 & 5.5 & \\
\hline $108-664 \mathrm{D}-18 \mathrm{H}-1,20$ & 154.50 & 93.9 & 0.3 & 5.8 & \\
\hline $108-664 \mathrm{D}-18 \mathrm{H}-1,30$ & 154.60 & 94.4 & 0.5 & 5.1 & \\
\hline $108-664 \mathrm{D}-18 \mathrm{H}-1,40$ & 154.70 & 94.8 & 0.8 & 4.4 & \\
\hline $108-664 \mathrm{D}-18 \mathrm{H}-1,49$ & 154.79 & 95.0 & 0.7 & 4.3 & \\
\hline $108-664 \mathrm{D}-18 \mathrm{H}-1,60$ & 154.90 & 94.6 & 0.7 & 4.7 & \\
\hline $108-664 \mathrm{D}-18 \mathrm{H}-1,70$ & 155.00 & 94.3 & 0.7 & 4.9 & \\
\hline $108-664 \mathrm{D}-18 \mathrm{H}-1,80$ & 155.10 & 93.8 & 0.8 & 5.4 & \\
\hline $108-664 \mathrm{D}-18 \mathrm{H}-1,90$ & 155.20 & 94.0 & 0.8 & 5.2 & \\
\hline $108-664 \mathrm{D}-18 \mathrm{H}-1,100$ & 155.30 & 93.4 & 0.2 & 6.4 & \\
\hline $108-664 \mathrm{D}-18 \mathrm{H}-1,110$ & 155.40 & 92.2 & 0.7 & 7.1 & \\
\hline $108-664 \mathrm{D}-18 \mathrm{H}-1,120$ & 155.50 & 91.5 & 0.6 & 7.9 & \\
\hline $108-664 \mathrm{D}-18 \mathrm{H}-1,130$ & 155.60 & 92.4 & 0.2 & 7.3 & \\
\hline $108-664 \mathrm{D}-18 \mathrm{H}-1,139$ & 155.69 & 93.5 & 0.6 & 5.9 & \\
\hline $108-664 \mathrm{D}-18 \mathrm{H}-2,10$ & 155.90 & 94.5 & 0.3 & 5.2 & \\
\hline $108-664 \mathrm{D}-18 \mathrm{H}-2,20$ & 156.00 & 92.4 & 0.7 & 7.0 & \\
\hline $108-664 \mathrm{D}-18 \mathrm{H}-2,30$ & 156.10 & 93.5 & 0.7 & 5.8 & \\
\hline $108-664 \mathrm{D}-18 \mathrm{H}-2,40$ & 156.20 & 92.7 & 0.6 & 6.6 & \\
\hline $108-664 \mathrm{D}-18 \mathrm{H}-2,49$ & 156.29 & 92.5 & 0.3 & 7.1 & \\
\hline $108-664 \mathrm{D}-18 \mathrm{H}-2,60$ & 156.40 & 94.8 & 0.3 & 4.8 & \\
\hline $108-664 \mathrm{D}-18 \mathrm{H}-2,70$ & 156.50 & 94.7 & 0.6 & 4.8 & \\
\hline $108-664 \mathrm{D}-18 \mathrm{H}-2,80$ & 156.60 & 94.8 & 0.2 & 5.0 & \\
\hline $108-664 \mathrm{D}-18 \mathrm{H}-2,90$ & 156.70 & 95.1 & 0.6 & 4.4 & \\
\hline $108-664 \mathrm{D}-18 \mathrm{H}-2,100$ & 156.80 & 95.3 & 0.3 & 4.4 & \\
\hline $108-664 \mathrm{D}-18 \mathrm{H}-2,110$ & 156.90 & 94.3 & 0.3 & 5.4 & \\
\hline $108-664 \mathrm{D}-18 \mathrm{H}-2,120$ & 157.00 & 93.0 & 0.1 & 6.8 & \\
\hline $108-664 \mathrm{D}-18 \mathrm{H}-2,130$ & 157.10 & 93.1 & 0.1 & 6.8 & \\
\hline 108-664D-18H-2, 140 & 157.20 & 93.5 & 0.1 & 6.4 & \\
\hline $108-664 \mathrm{D}-18 \mathrm{H}-3,10$ & 157.40 & 94.1 & 0.1 & 5.7 & \\
\hline $108-664 \mathrm{D}-18 \mathrm{H}-3,20$ & 157.50 & 91.5 & 0.3 & 8.2 & \\
\hline $108-664 \mathrm{D}-18 \mathrm{H}-3,30$ & 157.60 & 90.7 & 0.8 & 8.4 & \\
\hline $108-664 \mathrm{D}-18 \mathrm{H}-3,40$ & 157.70 & 90.5 & 0.5 & 9.1 & \\
\hline $108-664 \mathrm{D}-18 \mathrm{H}-3,49$ & 157.79 & 91.7 & 0.6 & 7.7 & \\
\hline $108-664 \mathrm{D}-18 \mathrm{H}-3,60$ & 157.90 & 94.9 & 0.3 & 4.8 & \\
\hline $108-664 \mathrm{D}-18 \mathrm{H}-3,70$ & 158.00 & 94.1 & 0.2 & 5.6 & \\
\hline $108-664 \mathrm{D}-18 \mathrm{H}-3,80$ & 158.10 & 94.6 & 0.4 & 4.9 & \\
\hline $108-664 \mathrm{D}-18 \mathrm{H}-3,90$ & 158.20 & 94.1 & 0.8 & 5.1 & \\
\hline $108-664 \mathrm{D}-18 \mathrm{H}-3,100$ & 158.30 & 94.2 & 0.6 & 5.1 & \\
\hline $108-664 \mathrm{D}-18 \mathrm{H}-3,110$ & 158.40 & 93.6 & 0.7 & 5.7 & \\
\hline $108-664 \mathrm{D}-18 \mathrm{H}-3,120$ & 158.50 & 93.2 & 0.7 & 6.1 & \\
\hline $108-664 \mathrm{D}-18 \mathrm{H}-3,130$ & 158.60 & 91.3 & 0.7 & 8.1 & \\
\hline $108-664 \mathrm{D}-18 \mathrm{H}-3,140$ & 158.70 & 90.6 & 0.7 & 8.8 & \\
\hline $108-664 \mathrm{D}-18 \mathrm{H}-3,149$ & 158.79 & 93.8 & 0.5 & 5.7 & \\
\hline $108-664 \mathrm{D}-18 \mathrm{H}-4,10$ & 158.90 & 92.2 & 0.2 & 7.5 & \\
\hline $108-664 \mathrm{D}-18 \mathrm{H}-4,20$ & 159.00 & 92.9 & 0.7 & 6.3 & \\
\hline $108-664 \mathrm{D}-18 \mathrm{H}-4,30$ & 159.10 & 93.7 & 0.6 & 5.8 & \\
\hline $108-664 \mathrm{D}-18 \mathrm{H}-4,40$ & 159.20 & 92.3 & 0.6 & 7.1 & \\
\hline $108-664 \mathrm{D}-18 \mathrm{H}-4,49$ & 159.29 & 88.3 & 0.9 & 10.8 & \\
\hline $108-664 \mathrm{D}-18 \mathrm{H}-4,60$ & 159.40 & 87.2 & 1.1 & 11.6 & \\
\hline $108-664 \mathrm{D}-18 \mathrm{H}-4,70$ & 159.50 & 89.1 & 0.8 & 10.0 & \\
\hline $108-664 \mathrm{D}-18 \mathrm{H}-4,80$ & 159.60 & 94.0 & 0.5 & 5.5 & \\
\hline $108-664 \mathrm{D}-18 \mathrm{H}-4,90$ & 159.70 & 93.1 & 0.4 & 6.5 & \\
\hline $108-664 \mathrm{D}-18 \mathrm{H}-4,100$ & 159.80 & 94.4 & 0.4 & 5.2 & \\
\hline $108-664 \mathrm{D}-18 \mathrm{H}-4,110$ & 159.90 & 93.7 & 0.1 & 6.2 & \\
\hline $108-664 \mathrm{D}-18 \mathrm{H}-4,120$ & 160.00 & 93.6 & 0.5 & 5.9 & \\
\hline $108-664 \mathrm{D}-18 \mathrm{H}-4,130$ & 160.10 & 94.4 & 0.3 & 5.3 & \\
\hline $108-664 \mathrm{D}-18 \mathrm{H}-4,140$ & 160.20 & 93.1 & 0.7 & 6.2 & \\
\hline $108-664 \mathrm{D}-18 \mathrm{H}-4,149$ & 160.29 & 92.1 & 0.7 & 7.2 & \\
\hline $108-664 \mathrm{D}-18 \mathrm{H}-5,10$ & 160.40 & 93.9 & 0.7 & 5.4 & \\
\hline $108-664 \mathrm{D}-18 \mathrm{H}-5,20$ & 160.50 & 93.5 & 0.6 & 5.9 & \\
\hline $108-664 \mathrm{D}-18 \mathrm{H}-5,30$ & 160.60 & 95.2 & 0.1 & 4.7 & \\
\hline $108-664 \mathrm{D}-18 \mathrm{H}-5,40$ & 160.70 & 93.0 & 0.9 & 6.0 & \\
\hline $108-664 \mathrm{D}-18 \mathrm{H}-5,49$ & 160.79 & 93.7 & 0.8 & 5.5 & \\
\hline $108-664 \mathrm{D}-18 \mathrm{H}-5,60$ & 160.90 & 94.3 & 0.8 & 4.9 & \\
\hline
\end{tabular}


Table 7 (continued).

\begin{tabular}{|c|c|c|c|c|c|}
\hline $\begin{array}{l}\text { Core, section, } \\
\text { interval }(\mathrm{cm})\end{array}$ & $\begin{array}{l}\text { Depth } \\
\text { (mbsf) }\end{array}$ & $\begin{array}{c}\mathrm{CaCO}_{3} \\
(\%)\end{array}$ & $\begin{array}{l}\mathrm{SiO}_{2} \\
(\%)\end{array}$ & $\begin{array}{c}\text { Terrigenous } \\
\text { fraction } \\
(\%)\end{array}$ & $\begin{array}{c}\text { Dry-bulk } \\
\text { density } \\
\left(\mathrm{g} / \mathrm{cm}^{3}\right)\end{array}$ \\
\hline $108-664 \mathrm{D}-18 \mathrm{H}-5,70$ & 161.00 & 94.1 & 0.7 & 5.2 & \\
\hline $108-664 \mathrm{D}-18 \mathrm{H}-5,80$ & 161.10 & 93.7 & 0.9 & 5.4 & \\
\hline $108-664 \mathrm{D}-18 \mathrm{H}-5,90$ & 161.20 & 90.9 & 0.9 & 8.2 & \\
\hline 108-664D-18H-5, 100 & 161.30 & 92.4 & 0.9 & 6.6 & \\
\hline 108-664D-18H-5, 110 & 161.40 & 92.3 & 0.8 & 6.8 & \\
\hline 108-664D-18H-5, 120 & 161.50 & 94.3 & 0.7 & 5.0 & \\
\hline 108-664D-18H-5, 130 & 161.60 & 94.9 & 0.4 & 4.7 & \\
\hline 108-664D-18H-5, 140 & 161.70 & 94.7 & 0.7 & 4.6 & \\
\hline 108-664D-18H-5, 149 & 161.79 & 94.5 & 0.7 & 4.8 & \\
\hline 108-664D-18H-6, 10 & 161.90 & 94.7 & 0.6 & 4.8 & \\
\hline $108-664 \mathrm{D}-18 \mathrm{H}-6,20$ & 162.00 & 94.9 & 0.5 & 4.6 & \\
\hline 108-664D-18H-6, 30 & 162.10 & 93.3 & 0.5 & 6.2 & \\
\hline $108-664 \mathrm{D}-18 \mathrm{H}-6,40$ & 162.20 & 94.6 & 0.6 & 4.8 & \\
\hline 108-664D-18H-6, 49 & 162.29 & 94.3 & 0.8 & 4.9 & \\
\hline $108-664 \mathrm{D}-18 \mathrm{H}-6,60$ & 162.40 & 94.4 & 0.7 & 4.8 & \\
\hline $108-664 \mathrm{D}-18 \mathrm{H}-6,70$ & 162.50 & 91.5 & 0.7 & 7.8 & \\
\hline $108-664 \mathrm{D}-18 \mathrm{H}-6,80$ & 162.60 & 91.2 & 0.7 & 8.1 & \\
\hline $108-664 \mathrm{D}-18 \mathrm{H}-6,90$ & 162.70 & 91.8 & 0.5 & 7.6 & \\
\hline 108-664D-18H-6, 100 & 162.80 & 91.4 & 0.6 & 8.0 & \\
\hline 108-664D-18H- 6,110 & 162.90 & 93.7 & 0.5 & 5.8 & \\
\hline 108-664D-18H-6, 120 & 163.00 & 92.7 & 0.4 & 6.9 & \\
\hline 108-664D-18H-6, 129 & 163.09 & 94.6 & 0.6 & 4.8 & \\
\hline 108-664D-19H-1, 10 & 163.90 & 88.4 & 0.8 & 10.8 & \\
\hline 108-664D-19H-1, 20 & 164.00 & 82.6 & 1.2 & 16.2 & \\
\hline 108-664D-19H-1, 30 & 164.10 & 85.6 & 1.1 & 13.3 & \\
\hline $108-664 \mathrm{D}-19 \mathrm{H}-1,40$ & 164.20 & 91.4 & 0.6 & 8.0 & \\
\hline 108-664D-19H-1, 49 & 164.29 & 92.3 & 0.5 & 7.3 & \\
\hline 108-664D-19H-1, 60 & 164.40 & 88.8 & 0.6 & 10.5 & \\
\hline 108-664D-19H-1, 70 & 164.50 & 93.1 & 0.6 & 6.4 & \\
\hline 108-664D-19H-1, 80 & 164.60 & 92.2 & 0.5 & 7.3 & \\
\hline $108-664 \mathrm{D}-19 \mathrm{H}-1,90$ & 164.70 & 94.0 & 0.7 & 5.3 & \\
\hline 108-664D-19H-1, 100 & 164.80 & 95.0 & 0.6 & 4.4 & \\
\hline 108-664D-19H-1, 110 & 164.90 & 94.4 & 0.6 & 4.9 & \\
\hline 108-664D-19H-1, 120 & 165.00 & 90.0 & 0.2 & 9.7 & \\
\hline 108-664D-19H-1, 130 & 165.10 & 91.5 & 0.8 & 7.7 & \\
\hline 108-664D-19H-1, 140 & 165.20 & 93.2 & 0.7 & 6.2 & \\
\hline 108-664D-19H-2, 10 & 165.40 & 92.6 & 0.6 & 6.8 & \\
\hline $108-664 \mathrm{D}-19 \mathrm{H}-2,20$ & 165.50 & 94.0 & 0.5 & 5.5 & \\
\hline $108-664 \mathrm{D}-19 \mathrm{H}-2,30$ & 165.60 & 93.2 & 0.4 & 6.4 & \\
\hline $108-664 \mathrm{D}-19 \mathrm{H}-2,40$ & 165.70 & 92.2 & 0.9 & 6.9 & \\
\hline $108-664 \mathrm{D}-19 \mathrm{H}-2,49$ & 165.79 & 92.6 & 0.9 & 6.5 & \\
\hline $108-664 \mathrm{D}-19 \mathrm{H}-2,60$ & 165.90 & 92.7 & 0.4 & 6.8 & \\
\hline $108-664 \mathrm{D}-19 \mathrm{H}-2,70$ & 166.00 & 91.8 & 1.1 & 7.1 & \\
\hline $108-664 \mathrm{D}-19 \mathrm{H}-2,80$ & 166.10 & 89.2 & 0.8 & 10.0 & \\
\hline $108-664 \mathrm{D}-19 \mathrm{H}-2,90$ & 166.20 & 89.5 & 1.0 & 9.6 & \\
\hline 108-664D-19H-2, 100 & 166.30 & 92.6 & 0.9 & 6.5 & \\
\hline 108-664D-19H-2, 110 & 166.40 & 92.6 & 0.8 & 6.6 & \\
\hline 108-664D-19H-2, 120 & 166.50 & 91.5 & 0.6 & 7.9 & \\
\hline 108-664D-19H-2, 130 & 166.60 & 91.4 & 0.6 & 8.0 & \\
\hline 108-664D-19H-2, 140 & 166.70 & 92.5 & 0.6 & 6.8 & \\
\hline 108-664D-19H-2, 149 & 166.79 & 93.4 & 0.2 & 6.4 & \\
\hline 108-664D-19H-3, 10 & 166.90 & 94.4 & 0.8 & 4.7 & \\
\hline 108-664D-19H-3, 20 & 167.00 & 94.1 & 0.6 & 5.3 & \\
\hline 108-664D-19H-3, 30 & 167.10 & 93.2 & 0.2 & 6.6 & \\
\hline $108-664 \mathrm{D}-19 \mathrm{H}-3,40$ & 167.20 & 93.4 & 0.9 & 5.7 & \\
\hline 108-664D-19H-3, 49 & 167.29 & 92.8 & 0.8 & 6.4 & \\
\hline
\end{tabular}

Table 7 (continued).

\begin{tabular}{|c|c|c|c|c|c|}
\hline $\begin{array}{l}\text { Core, section, } \\
\text { interval }(\mathrm{cm})\end{array}$ & $\begin{array}{l}\text { Depth } \\
\text { (mbsf) }\end{array}$ & $\begin{array}{c}\mathrm{CaCO}_{3} \\
(\%)\end{array}$ & $\begin{array}{c}\mathrm{SiO}_{2} \\
(\%)\end{array}$ & $\begin{array}{c}\text { Terrigenous } \\
\text { fraction } \\
(\%)\end{array}$ & $\begin{array}{c}\text { Dry-bulk } \\
\text { density } \\
\left(\mathrm{g} / \mathrm{cm}^{3}\right)\end{array}$ \\
\hline $108-664 \mathrm{D}-19 \mathrm{H}-3,60$ & 167.40 & 92.3 & 0.7 & 6.9 & \\
\hline $108-664 \mathrm{D}-19 \mathrm{H}-3,70$ & 167.50 & 93.7 & 0.4 & 6.0 & \\
\hline $108-664 \mathrm{D}-19 \mathrm{H}-3,80$ & 167.60 & 92.3 & 0.7 & 7.0 & \\
\hline 108-664D-19H-3, 90 & 167.70 & 93.7 & 0.6 & 5.7 & \\
\hline $108-664 \mathrm{D}-19 \mathrm{H}-3,100$ & 167.80 & 93.6 & 0.4 & 5.9 & \\
\hline 108-664D-19H-3, 110 & 167.90 & 92.4 & 0.8 & 6.9 & \\
\hline $108-664 \mathrm{D}-19 \mathrm{H}-3,120$ & 168.00 & 91.1 & 0.9 & 7.9 & \\
\hline 108-664D-19H-3, 130 & 168.10 & 86.7 & 1.1 & 12.2 & \\
\hline $108-664 \mathrm{D}-19 \mathrm{H}-3,140$ & 168.20 & 84.9 & 1.3 & 13.8 & \\
\hline 108-664D-19H-3, 149 & 168.29 & 87.2 & 1.1 & 11.7 & \\
\hline 108-664D-19H-4, 10 & 168.40 & 93.1 & 0.6 & 6.3 & \\
\hline 108-664D-19H-4, 20 & 168.50 & 95.1 & 0.7 & 4.2 & \\
\hline $108-664 \mathrm{D}-19 \mathrm{H}-4,30$ & 168.60 & 92.5 & 0.6 & 6.9 & \\
\hline $108-664 \mathrm{D}-19 \mathrm{H}-4,40$ & 168.70 & 93.6 & 0.7 & 5.7 & \\
\hline 108-664D-19H-4, 49 & 168.79 & 91.6 & 0.7 & 7.7 & \\
\hline $108-664 \mathrm{D}-19 \mathrm{H}-4,60$ & 168.90 & 90.9 & 0.7 & 8.4 & \\
\hline 108-664D-19H-4, 70 & 169.00 & 89.8 & 0.8 & 9.4 & \\
\hline $108-664 \mathrm{D}-19 \mathrm{H}-4,80$ & 169.10 & 90.1 & 1.0 & 8.9 & \\
\hline 108-664D-19H-4, 90 & 169.20 & 87.5 & 1.1 & 11.4 & \\
\hline $108-664 \mathrm{D}-19 \mathrm{H}-4,100$ & 169.30 & 90.3 & 0.5 & 9.1 & \\
\hline $108-664 \mathrm{D}-19 \mathrm{H}-4,110$ & 169.40 & 93.6 & 0.6 & 5.8 & \\
\hline $108-664 \mathrm{D}-19 \mathrm{H}-4,120$ & 169.50 & 94.1 & 0.6 & 5.2 & \\
\hline $108-664 \mathrm{D}-19 \mathrm{H}-4,130$ & 169.60 & 94.4 & 0.7 & 5.0 & \\
\hline $108-664 \mathrm{D}-19 \mathrm{H}-4,140$ & 169.70 & 94.4 & 0.8 & 4.8 & \\
\hline 108-664D-19H-4, 149 & 169.79 & 95.4 & 0.8 & 3.8 & \\
\hline 108-664D-19H-5, 10 & 169.90 & 94.6 & 0.8 & 4.7 & \\
\hline 108-664D-19H-5, 20 & 170.00 & 92.6 & 0.8 & 6.6 & \\
\hline 108-664D-19H-5, 30 & 170.10 & 92.6 & 0.9 & 6.5 & \\
\hline $108-664 \mathrm{D}-19 \mathrm{H}-5,40$ & 170.20 & 93.5 & 0.6 & 5.9 & \\
\hline 108-664D-19H-5, 49 & 170.29 & 91.5 & 0.7 & 7.8 & \\
\hline 108-664D-19H-5, 60 & 170.40 & 93.2 & 0.8 & 5.9 & \\
\hline 108-664D-19H-5, 70 & 170.50 & 93.4 & 0.8 & 5.8 & \\
\hline 108-664D-19H-5, 80 & 170.60 & 91.6 & 0.7 & 7.7 & \\
\hline $108-664 \mathrm{D}-19 \mathrm{H}-5,90$ & 170.70 & 92.7 & 0.8 & 6.5 & \\
\hline 108-664D-19H-5, 100 & 170.80 & 91.8 & 0.8 & 7.4 & \\
\hline 108-664D-19H-5, 110 & 170.90 & 92.9 & 0.8 & 6.3 & \\
\hline 108-664D-19H-5, 120 & 171.00 & 92.4 & 0.7 & 6.9 & \\
\hline $108-664 \mathrm{D}-19 \mathrm{H}-5,130$ & 171.10 & 92.7 & 0.7 & 6.7 & \\
\hline $108-664 \mathrm{D}-19 \mathrm{H}-5,140$ & 171.20 & 92.2 & 0.7 & 7.1 & \\
\hline 108-664D-19H-5, 149 & 171.29 & 92.9 & 0.9 & 6.2 & \\
\hline 108-664D-19H-6, 10 & 171.40 & 91.5 & 0.6 & 7.9 & \\
\hline 108-664D-19H-6, 20 & 171.50 & 93.1 & 0.8 & 6.0 & \\
\hline 108-664D-19H-6, 30 & 171.60 & 92.9 & 0.8 & 6.3 & \\
\hline 108-664D-19H-6, 40 & 171.70 & 93.3 & 0.9 & 5.8 & \\
\hline 108-664D-19H-6, 49 & 171.79 & 93.2 & 0.9 & 5.9 & \\
\hline 108-664D-19H-6, 60 & 171.90 & 92.8 & 0.8 & 6.4 & \\
\hline 108-664D-19H-6, 70 & 172.00 & 94.1 & 0.7 & 5.2 & \\
\hline 108-664D-19H-6, 80 & 172.10 & 93.3 & 0.8 & 5.9 & \\
\hline $108-664 \mathrm{D}-19 \mathrm{H}-6,90$ & 172.20 & 93.5 & 0.8 & 5.7 & \\
\hline $108-664 \mathrm{D}-19 \mathrm{H}-6,100$ & 172.30 & 93.3 & 0.8 & 5.9 & \\
\hline 108-664D-19H-6, 110 & 172.40 & 93.6 & 0.4 & 5.9 & \\
\hline
\end{tabular}

Note: Average shipboard-measured dry-bulk densities (in $\mathrm{g} / \mathrm{cm}^{3}$ ) used to calculate fluxes in Cores 108-664D-15H through -19H were: Core 108$664 \mathrm{D}-15 \mathrm{H}=1.07$, Core $108-664 \mathrm{D}-16 \mathrm{H}=1.03$, Core $108-664 \mathrm{D}-17 \mathrm{H}=$ 1.09 , Core 108-664D-18H $=1.00$, and Core 108-664D-19H $=1.04$. 